


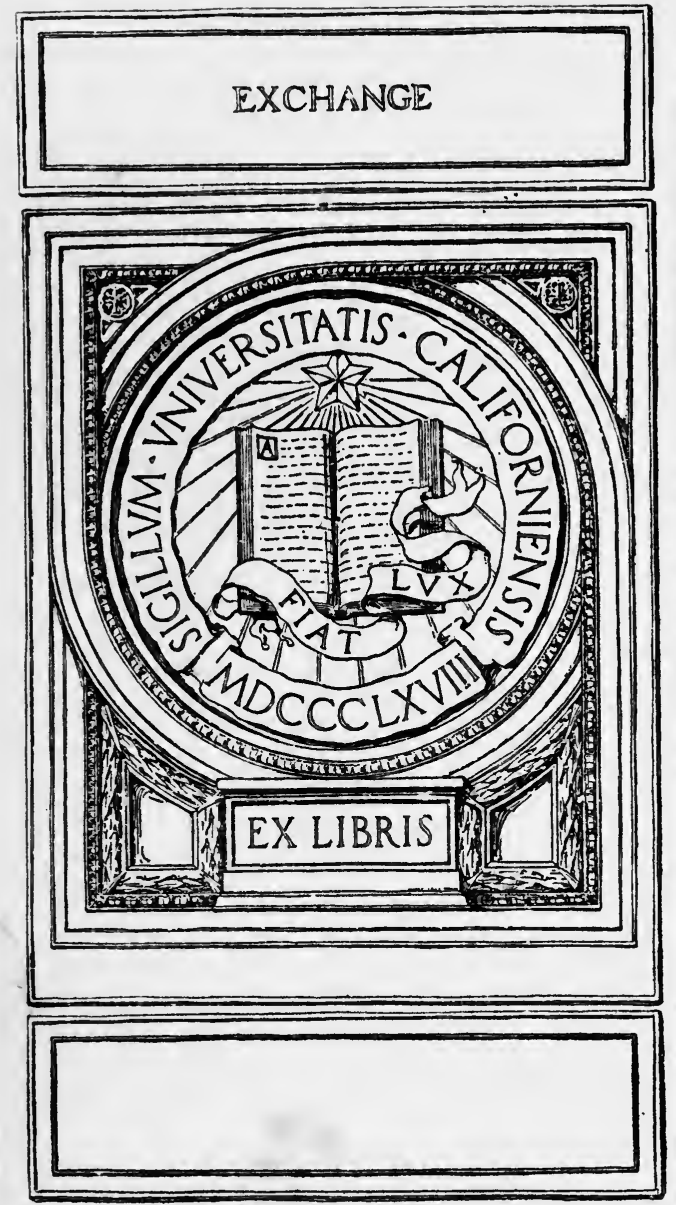







\section{AMERICANA GERMANICA}

MONOGRAPHS DEVOTED TO THE COMPARATIVE STUDY OF THE

Literary, Linguistic and other Cultural Relations

OF

Germany and America

EDITOR

MARION DEXTER LEARNED

Unirereity of Penneylrania 


\section{BELIEFS AND SUPERSTITIONS}

\section{OF THE PENNSYLVANIA}

\section{GERMANS}

BY

EDWIN MILLER FOGEL, Ph.D. 
COPYRIGHT 1915

by

EDWIN M. FOGEL.

Trinted by

J. J. Nungesser

Herribburt, Pa. 


\section{PREFACE.}

Part of the material of the following pages was originally collected and presented in partial fulfillment of the requirements for the degree of Doctor of Philosophy in the University of Pennsylvania. Since then the treatise has been revised throughout and much new material added. These additions consist, in the main, of parallels or correlates which were found in various European libraries or gathered by word of mouth in those districts of Germany from which most of the ancestors of the Pennsylvania Germans emigrated to America.

The aim of the present volume is two-fold. It is intended primarily as a contribution not only to American Folklore but more especially as a chapter in the larger field of German American relations, the pioneer exponent of which is the present Professor of the Germanic Languages and Literatures in the University of Pennsylvania. Other considerations, secondly, have made it imperative that the general public should be interested in the book. It has therefore been deemed advisable to adopt a simpler phonetic notation in reproducing the vernacular than might otherwise have been permissible.

It should be emphasized that the contents of the present volume are to be regarded as a serious attempt at putting into permanent form a phase of folk-life which will soon disappear into the background and thus be irretrievably lost. This book is therefore not intended as a source of supply for those whose aim in speaking and writing about the Pennsylvania Germans seems to be to exaggerate and misrepresent.

Special acknowledgment must be given to the following: to Professor Marion D. Learned for most valuable sug. gestions in the inception of the collection and for that encouragement which alone comes from an inspiring leader; 
to Professor Daniel B. Shumway whose success in translation has made his suggestions and corrections in the translation of the dialect material invaluable; to Professors Friedrich Pfaff, of Freiburg, i. B., Karl Bohnenberger, of Tübingen, and Paul Hintzelmann, of Heidelberg, for special favors in the respective University libraries; to Professor Theodor Zink, of Kaiserslautern, and Mr. H. Bauer, of Freiburg, i. B., for kindly assistance in indicating where many of the superstitions were to be found; to Professor Philip H. Fogel, of Princeton University; and finally to friends and acquaintances in Pennsylvania who made the collection of material possible.

Philadelphia, 1915. 


\section{CONTENTS.}

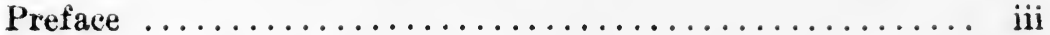

Introduction ............................. 1

Bibliography and Abbreviations ................. 23

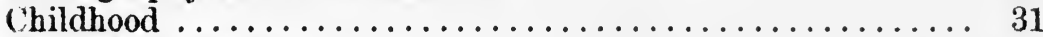

Future Husband $\ldots \ldots \ldots \ldots \ldots \ldots \ldots \ldots \ldots \ldots \ldots \ldots$

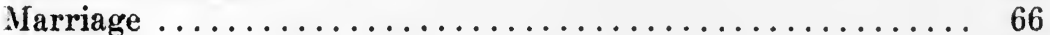

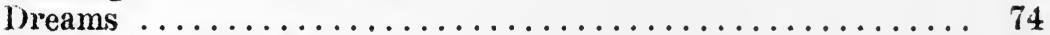

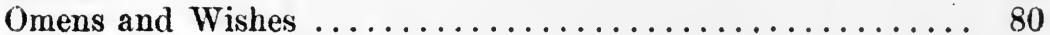

Luck and Omens of Luck ...................... 98

Omens of Death ............................... 114

Death Omens Concerning Death .................. 126

Superstitions Connected with Death ............... 129

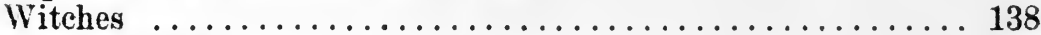

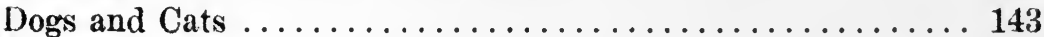

Moving .............................. 148

Homesickness ............................ 152

Servants ................................ 154

Stockraising and Veterinary Medical Superstitions ........ 155

Milk and Butter ........................ 177

Cooking and Baking ....................... 187

Vinegar ................................ 190

Planting, Sowing and Reaping ................. 194

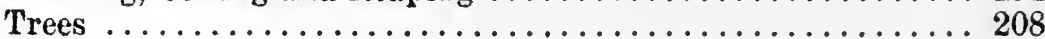

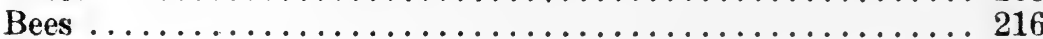

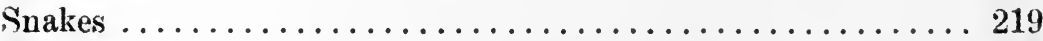

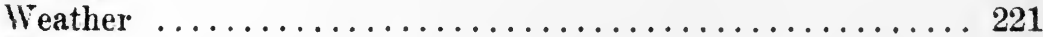

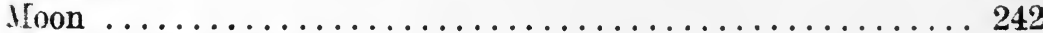

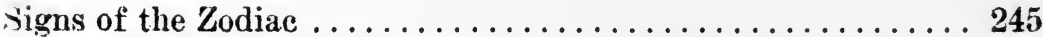

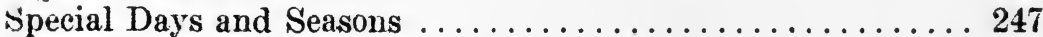

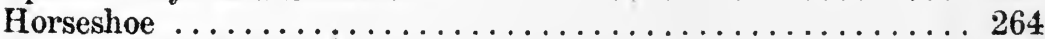

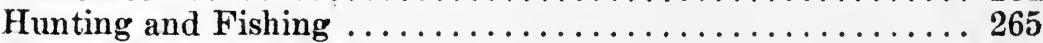

Folk Medicine and Medical Superstitions ........... 267

Freckles ................................. 307

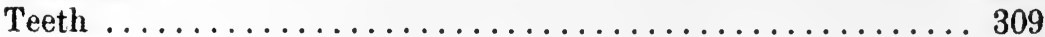

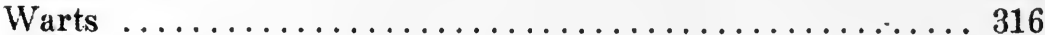

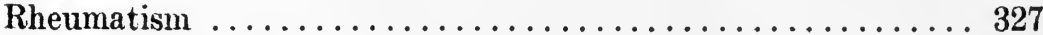

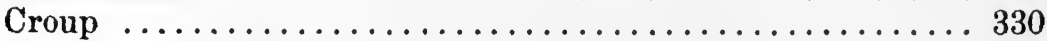

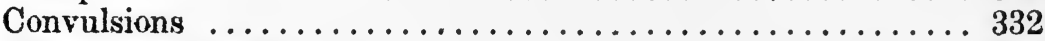

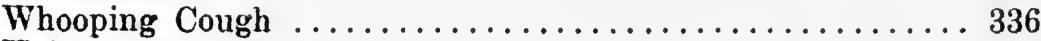

Hair ................................. 340

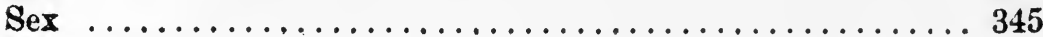

Miscellaneous ............................ 358 



\section{INTRODUCTION.}

German colonization in the western hemisphere is almost coeval with the discovery of America by Columbus. Under the aegis of the great German merchant princes, the Welsers and the Fuggers, attempts at colonization were made, before the third decade of the sixteenth century, on both coasts of South America. Welser's attempt resulted in the founding of "Klein Venedig," Venezuela, between 1528 and 1535; Fugger's along the west coast, being a failure. There were German Protestants among the settlers at Port Royal (1562) and at Jamestown (1607). The first German of importance mentioned in connection with the Dutch settlements in New York was Peter Minnewit, although there were Germans among both the Dutch in New Netherlands and New Sweden on the Delaware (1638-1655). The Crefelders came to Philadelphia on the sixth of October 1683, the most important date in the history of German emigration to America. It is estimated that more than five millions of Germans have settled on our shores, and they constitute one of the most important factors in American history.

The second decade of the nineteenth century seems to divide these German immigrants into two great classes, the former of whom came to escape religious persecution or because of the devastations in the Rhenish Palatinate by the French; the latter came as a result of political upheavals in the fatherland. It is obvious that those who have come since 1818 , and more especially those who followed in the wake of the 48-ers are drawn from quite different strata of society. The former settled in the country, the latter in the cities. It is those who came before 1818 who are the forebears of the Pennsylvania Germans. The immigrants settled in practically every county in Pennsylvania, there being twentyeight counties with distinctively Pennsylvania German settlements before 1850. Many of them migrated from Penn- 
sylvania to almost every state of the Union north of $36^{\circ} 30^{\prime}$, as well as Canada.

The Penusylvania Germans, as a whole, are the result of the great Pfälzereinwanderung which began in 1709-10. With these Palatines came also some Swiss, and their presence is still felt dialectally in Lancaster and York counties. However, the dialect of the superstitions given in the following pages is strikingly similar to that spoken in the Rhenish Palatinate at the present time. In order to ascertain whether the superstitions were extant in various sections of Germany, the author read them in their native dialect to those who spoke allied dialects. It was exceedingly interesting to note the ease with which the dialect was understood throughout Baden and the Rhenish Palatinate, whereas in Swabia it was only with difficulty that the import of the material read was understood. After hearing probably a third of the superstitions of the present collection one of the Gymnasialprofessoren in Kaiserslautern who has devoted considerable time to dialect study remarked: "Die ganz charakteristischen Ausdrücke des Pfälzers sind in der pennsylvanischdeutschen Mundart zu finden." This statement is quoted here only for the purpose of contradicting those who say that "Pennsylvania German is nothing but a mixture of bad English and worse German." The most striking features of the dialect as shown by the text of the superstitions are: a purely German word order; the use of prepositions with the proper case, the absence of the imperfect tense except in tense auxiliaries, and the use of tun as an additional auxiliary of tense. The dialect student will therefore agree that Pennsylvania German takes rank with the most important dialects of Germany and that the presence of English words does not in any way militate against such position, for, after all, the vocabulary of a people is conditioned to a great extent by environment and other potent social influences.

In the present study only the more distinctive Pennsylvania German counties were taken into consideration, 
viz : Berks, Bucks, Carbon, Dauphin, Lebanon, Lehigh, Lancaster, Monroe, Montgomery, Northampton, Northumberland, Schuylkill, Snyder and York. They cover an area of more than 8000 square miles and have a population of more than one and one quarter millions. It is very much to be regretted that the directors of the United States Census have not seen fit to take cognizance of the dialectal peculiarities of our population, and therefore the census does not shed any light on the probable number of those who can speak a language other than English. It would seem a conservative estimate to say that more than 500,000 people in Pennsylvania alone understand Pennsylvania German and that 300,000 speak the dialect.

Almost all the Christian denominations are represented in the Pennsylvania population, with, however, few Presbyterians and Episcopalians; for the Reformed Church in the United States is the German counterpart of the British Presbyterians. In this territory there are, so far as can be ascertained, only two Catholic settlements, one in Berks and the other in York county. Schafferstown, Lebanon county, was the oldest Jewish settlement in Pennsylvania, but with the exception of the cemetery there, there are no traces left of the Jewish community. The German Reformed (Reformirte) and Lutherans (Luterăner) were among the first settlers and are at the present time numerically stronger than any other of the denominations or sects. The Mennonites (Monischte), to be sure, came earlier, but there are not very many of them except in Lancaster county. The Amish (Amische), also called "hooker" Mennonites are one of the dozen branches of the Mennonites. The Schwenkfeldians (Schwenkfelder) and Moravians (Hærrnhūter) came before 1741. The Methodists (Medodiste) are not numerous but there are many Evangelicals (Efangēlische) and the United Brethren (Fereinigte Brider or Schtratbler). Chief among the sectaries are the Dunkards (Dunker), Seventh Day Adventists (Efretenser or Sibe Dēğer), River 
Brethren (Reber Brtder), Baptists, [?] (Widerdeifer), Weinbrennarians (Weinbrenner) and Brinsers or United Zion Children. Many of these wear "plain clothes" and some of them have no church buildings and worship in private houses. The Pennsylvania Germans have, in many respects, clung to the customs and beliefs which their ancestors brought with them from the fatherland. In their devotions they still use their Arndt's Wahres Christentum and Stark's Gebetbuch, the German Bible and Catechism and Hymnbook. And there are still traces of the mysticism of Tauler, Böhme and Spener.

Most of the denominations and sectaries are nonliturgical and have a free service, even though they may have an episcopal government. Many of them are closecommunionists and forbid intermarriage. In many of the churches the sexes are still segregated after the fashion in the Stiftskirche in Tübingen. Where German is the pulpit language it is not the lumbering style of the present day German so often heard in German pulpits, but rather a simple modified Luther German without, in many instances, any serious effort at correctness in inflectional endings. In many sections of the Pennsylvania German territory English is rapidly supplanting Pennsylvania German or German as the pulpit language under the influence of the public schools and a consequent apparent disregard for German.

The Pennsylvania German takes considerable interest in education, as is shown by the number of so-called smaller colleges and other schools in this territory. Many of them were founded with the express purpose of preparing young men for the Christian ministry. Some of the schools in this territory were however not due to any German impulse. The principal schools and colleges in the Pennsylvania German district are: Keystone State Normal School in Berks; Lebanon Valley College (United Brethren) and Albright College (United Evangelical) in Lebanon; Muhlenberg College (Lutheran) and Allentown College for Women (German Reformed) in Lehigh; Franklin and Marshall College 
(German Reformed), Linden Hall Seminary (Moravian) and Millersville State Normal School in Lancaster ; Stroudsburg State Normal School in Monroe; Ursinus College (German Reformed) and Perkiomen Seminary (Schwenkfeldian) in Montgomery; Lehigh University (non-sectarian), Lafayette College (originally Presbyterian), Moravian College and Theological Seminary, Moravian Seminary for Young Ladies and Nazareth Hall (Moravian) in Northampton; Freeburg College of Music and Susquehanna University (Lutheran) in Snyder; York Collegiate Institute in York. Besides these, Pennsylvania College (Lutheran) in Gettysburg and Dickinson College (Methodist) in Carlisle draw many students from the Pennsylvania German field.

But there is another phase to this picture which is equally important culturally - the traditions, beliefs and superstitions of the people.

The material of the following pages was collected entirely by the author by word of mouth. No printed collections, of which there are probably a score, were taken into consideration, as they are all small, the largest of them containing less than 150 superstitions. (Among these may be mentioned: several collections in the American Journal of Folklore; History of Lehigh and Carbon Counties; Folklore and Superstitious Beliefs of Lebanon County, by E. Grumbine; Local Superstitions, in Proceedings of Lancaster County Historical Society; Phoebe Gibbons: The Pennsylvania Germans; etc. etc.) The author therefore had to begin collecting by asking his friends and acquaintances in his home county for any superstitions which they might know or have heard. These were immediately written down and read to the next person interviewed, for, "that reminds me" applies to superstitions as well as to stories. By this method variants and new superstitions were gathered until the collection numbered about 500, after which the other Penn. sylvania German counties were canvassed in the same way. All material was written down just as it was given, for it 
was the author's purpose to get a permanent record of the spoken vernacular with all its dialectal peculiarities. This accounts for the variations in spelling and word usage and is the main reason for publishing the superstitions in the original, since by this method it is made possible to have a permanent record of a distinctive German dialect on foreign soil and in the beginning of the twentieth century.

To prove that virtually all the superstitions of the present collection are importations and in that sense survivals of German and British superstitions the use of correlates was decided upon. This was done wherever such correlates could be found in the voluminous literature in the field of folklore in the libraries of the University of Pennsylvania and Columbia University ; in the Royal Library in Berlin, the University libraries at Heidelberg, Tübingen and Freiburg; and in the British Museum in London. After this bibliography as well as unpublished manuscript material of Professors Pfaff, of Freiburg, and Bohnenberger, of Tübingen, had been exhausted, the author resorted to the same methods to find correlates in South Germany as had been successfully used in the Pennsylvania German field. Whenever a superstition was found to have a correlate, it was noted and is to be found immediately after the name of the counties in which the respective superstition occurs here. In this way the author has added several hundred superstitions to the German collections.

Research in the British Museum was undertaken with the express purpose of trying to ascertain how many of the superstitions in the present collection had a British, or German, or common origin. Unfortunately, the British have never paid much attention to superstitions and in this field are far outclassed by their German cousins. In almost all the British collections we read this sentence: "and many more superstitions of the same kind." It is therefore impossible to even approximate the probable influence of British superstition, including, of course, the Irish and Scotch-Irish, on the Pennsylvania Germans. In the present 
collection less than a hundred are of purely British origin, and only 269 additional superstitions are common to both Great Britain and Germany, whereas over 1400 have German correlates. That this disparity is entirely too great is obvious and it shows only too plainly that the British Folklore Society has not done for Great Britain what the friends of Volkskunde have done for Germany in collecting and publishing every bit of folklore material. And more is the pity since much very valuable material will soon be irretrievably lost. Again, in the present collection 65 per cent. of the superstitions have German correlates, less than 5 per cent. purely British, 19 per cent. British and German, and about 20 per cent. seem to be indigenous to Pennsylvania German soil, an apparently very large percentage, which is however easily accounted for by the large number of variants, many of them occurring in only a single county. The word correlate as here used has two meanings: (1) that a Pennsylvania German superstition is a literal and exact survival or importation, e. g. wanmmer alles esst as uf em disch is såkt mer als, es gebt gūt wetter : wenn die auf den tisch gebrachten speisen rein aufgegessen werden, gibts am andern tag gut wetter $(B S 33.135) ;(2)$ that the underlying thought is of similar import, e. g., mer soll åranzwibel ins essichfass dū fer gūter essich : Orant ist gut für gespenst oder zauberei angehängt. ( $Z f D M 4.42)$. Of these two classes the latter is best represented, and it does not seem difficult to explain why this should be so, when we stop to think that most of these superstitions and beliefs have been handed down from generation to generation by word of mouth and very few have been transmitted in book form, as is shown by the variants of the same superstition in different localities.

Almost every phase of activity is represented in the superstitions of the following pages. It is quite natural that childhood, marriage, death, luck, medicine and the 
weather should be so well represented. That Saints' Days are comparatively poorly represented is to be accounted for from the fact that Catholicism has never had any appreciable influence among the Pennsylvania Germans and that the early German settlers came from Protestant territory. A few of the superstitions can be traced back to Germanic heathendom. In tracing these survivals much valuable information has been derived from Golther's Handbuch der Germanischen Mythologie, Grimm's Deutsche Mythologie, Meyer's Germanische Mythologie, Meyer's Mythologie der Germanen, and Wuttke's Der deutsche Volksaberglaube der Gegenwart. These books are mentioned here so as not to necessitate the constant repetition of citations.

Tuesday, named for Tiw, Ziu, Tyr, and Thursday, named for Thor, Donar, are the favorite wedding days in most of the Pennsylvania German counties, although custom varies in this respect in different localities. Donar's hammer, mjölnir, is reflected in the superstition "for insomnia put a rūkschtē under your pillow." The rūkschtē is a roundish stone found lying on fenceposts and is the Pennsylvania German interpretation of the Donarkeil or belemnite. Red objects such as the houseleek, the mountain ash, rowan-berries, the oak with its red bark, animals having a red color, even red objects, such as stockings, bands, garters, coats, wax tapers, etc., were sacred to him. Collargall may thus be prevented or cured by putting the skin of a weasel or oppossum under the collar. It is probably for the same reason that red flannel underwear is worn to prevent rheumatism. Since Donar was the god of marriage and since everything red was sacred to him, the tying of a piece of red flannel around the leg to stop puerperal hemorrhage is a direct survival of the old paganism. "In British superstition a piece of red tape was tied round one of the thighs of a woman in childbed, as it was supposed to mitigate the labor pains and to prevent mishap." (CFY 76). The tying of a piece of red wool or string about the finger to stop nosebleed, and the passing of red cord over 
the parts afflicted with erysipelas belong to the same category, notwithstanding the claim of those who maintain that they are based solely on the old similia similibus curantur. Because Donar was the god of the hearth and the family, the kettlehook was sacred to him. Herein lies the source of the superstition of looking into the chimney to prevent homesickness.

The Anglo-Saxons picked the herbs which they used for medicinal purposes on Thursday, and in all the Pennsylvania German counties it is customary to eat some greens, such as spinach, dandelion, etc., on Maundy Thursday to prevent fever. For "livergrown" ereep under a vine or bramble that has taken second root, or pass the "livergrown" child through a horse collar or through a rent or hole in a tree. In pagan times sick children were passed through a hole in an oak tree, or ash tree, or hip tree (Rosa canina) on three successive Thursdays. The reference to the horse collar is interesting because the horse was sacred to Wodan.

Thor's image was put on the prow of the boat, the sailors in this manner imploring Thor for favorable winds. After the introduction of Christianity the image of Thor was supplanted by the crucifix and now the crucifix is replaced by allegorical figures, in other words, a return to paganism.

In early times cattle were driven to pasture for the first time on Thursdays, and in most Pennsylvania German counties you will not find a moving on Monday, Wednesday or Friday, and the place taken by cattle in the moving is likewise interesting.

Eating something green on Maundy Thursday to protect one's health or using an egg laid on Maundy Thursday to reduce hernia, combine in them pagan and Christian elements, for in superstition Maundy Thursday is an exceedingly lucky day. On Ascension Day, likewise a Thursday, you may always expect a thunderstorm; you should never 
sew on this day or frame a house, for lightning will strike anything which is made on this day. Curiously enough, this is the day to go fishing, whereas in Germany rivers are supposed to demand and receive a sacrifice on this day. Picking one's teeth with a splinter from a tree struck by lightning and never using such wood for building purposes or fuel, all reflect the Donar cult, just as do the tooth of the boar and the mouse, for they are the symbols of the flash of lightning. Shrove Tuesday has taken over some of the features of the festival in honor of Donar, for, at this time, the heathen Germans celebrated a preliminary festival in honor of the coming spring and the end of winter. The cakes which were eaten at this time are closely related to the Easter cakes in honor of Ostara, the goddess of the light of spring. This explains why one should eat a doughnut on Shrove Tuesday in order to live a year longer. Nor should any work be done on this day.

In the entire heathen calendar no day was more sacred than May 1, for it was dedicated to Donar. The night preceding is Walpurgis night, the time when all spirits are freed. Both day and night are the time for charms and spells, and one can now understand why one should wash with dew on the first of May without, however, speaking a word, to get rid of freckles. Under the influence of Christianity, many of the characteristics of the gods were transferred to the devil. Thus, one frequently says of a red headed person: "rōte hōr uf em kopp, der deibel im leib," or one says that "either a sorrel horse is tricky or his mas. ter is." So also, Judas, the man of Kerioth, is represented as having red hair and therefore he betrayed Christ. The fiery dragon, which disappears as soon as one speaks, and the cuckoo are also to be referred to Donar.

The last of the major gods is Wodan, and it is for him that Wednesday is named. The Saxons, Frisians and lower Franks adopted the name Wuotanestac, but in High German territory the name Mittwoch remained, and it is probable that the High German tribes did not know of a god 
Wodan, which corresponded to Mercurius, at the time of the introduction of Roman names for the days of the week. North Germany seems to have been the home of the Wodan cult and it is not until rather late, probably the seventh century, that this Wodan cult reached High German territory. At all events, we can understand why "Mittwoch is ken dak," because, not being named for a god, it is a day of bad luck. Nothing of importance must be done on this day and it is extremely rare that a funeral is held on a Wednesday. Wodan had a raven which he sent out each day to gather news for him, and he also summonded his heroes to Walhalla, therefore when a crow crosses one's path it is an omen of bad luck or death. It is also the Wodan cult that is responsible for the superstitions of the horse shoe and horseshoe nail. The horse was sacred to Wodan, as was also the horse head. It is probable that the use of a found bone in curing diseases is closely related to the Wodan cult because bones of horses were used in curing various diseases.

The broom which plays so great a role in witchcraft as well as in cleaning house and barn on Good Friday was sacred to Donar and Wodan because of its relation to lightning. The most important remnant of the Wodan myth is to be found in "Der wilde Jäger," the "Wild Huntsman," which survives in "der ëwich jëger" with some non-essential additions and variations. It is quite natural that the period between Christmas and Epiphany (Jan. 6) should be so well represented in superstition. The "Wild Huntsman" is supposed to cause storms during this period. Therefore if it is windy between Christmas and New Year, there will be much fruit the coming year. St. Niklas, called "Belznikel" by the Pennsylvania Germans, can be traced back to Wodan. He usually wears a long white beard and distributes nuts, apples, etc., among the children. It is a question also whether the "Mummers" do not hark back to the Wodan cult. 
The Germanic Venus is Frigg, and dies Veneris is translated into Freitag, Friday. She is known by many names and is hard to delineate in Germanic mythology. As the wife of Wodan she drives in a chariot drawn by cats, as the cat is sacred to her. She is a fructifying goddess and therefore sowing should be begun and finished on Friday. Many of the characteristics of Hel are transferred to her, and, as such, the owl is her messenger, and the hooting of the owl is an omen of death.

It will be seen, then, that the days named for the several Germanic divinities play an important rôle in the everyday life of the people. As is to be expected, these gods were worshipped in many forms, and it is to these pagan rifes that we can trace some of our present day superstitions.

When sacrifice was made to the gods much attention was paid to the viscera and blood of sacrifices, on the basis of which the priests prophesied. The horse was the most important sacrificial animal-more so even than human beings, for when human beings were sacrificed it was usually criminals-and thus much significance attached to the neighing of horses. So, the neighing of horses at a funeral is the sign of another funeral soon.

If a child was named for a god it was under the especial protection of that god. So there are compounds of As, Regin, Os, etc., as in Oscar, Reginald, Oswald, etc. It is likely that the same thought is expressed in names like Gotthold, Gottfried, Gottlieb, Gottlob, and Godfrey and in giving a saint's name to a child born on a saint's day.

The Germanic people naturally gave presents to their gods, and they were usually simple in kind, being principally food, milk, honey, fruits and flowers. When the farmer puts hay out of doors on Christmas eve, so that the dews of night might fall on it, and feeds the hay on Christmas day to horses and cattle, so that they may be healthy all the year; or if when one sets out bread into the open air on Christmas day to freeze and later eats such bread to 
prevent fevers, these practices may be regarded as survivals of the sacrifice offered by the Germanic peoples at the most important period in the entire pagan Germanic calendar, twelf thtide. Here should be mentioned also the Christmas tree with its symbolic decorations, and the general custom among all peoples of Germanic extraction of having a sumptuous dinner on Christmas day, for they are survivals of the solemn sacrificial feasts about the time of the winter solstice. The belief in the speaking of animals on Christmas eve between eleven and twelve o'clock comes from Germanic mythology, as does also the belief that a child born on Christmas day is extraordinarily lucky. The old superstition of water in wells turning into wine for a space of three minutes during Christmas night is likewise pagan in its origin.

The Germanic peoples held four great sacrifices during the year: when they drove their cattle to pasture in spring, about May; when they rounded them up in fall after harvest, about September; about the time of the summer solstice to secure themselves against damage from hail and thunderstorm, as well as plagues; in winter, for the coming year's crops. In the case of plague among the domestic animals the finest specimen of the flock or herd which was being devastated was selected for sacrifice, and the sex of the animal to be sacrificed was determined by the sex of the larger number of animals that had died. In such cases the sacrifice consisted in either burying the animal thus selected alive or beheading it. There is an echo of this sacrificial act in the Pennsylvania German superstition of burying the stillborn calf under the sill of the stable door.

For our present purpose it is necessary to give some details of the ceremonies connected with Germanic sacrifice. Every one who wished to participate in the blessings of the sacrifice was required to contribute something to the sacrificial pyre, before virgin fire was applied to it. After the fire had died down, the herds were driven through the burn- 
ing embers: first pigs, then cows and horses, and finally geese. Men and women also ran through the flames, blackening each other's faces with the sacred, healthgiving ashes. Fruit trees, meadows and fields were smoked with the burning embers. Some of the embers were taken home to rekindle the hearth fires which had been extinguished before the beginning of the sacrifice. The extinguished embers were placed in the manger to assure the health of the cattle. When, therefore, in all the Pennsylvania German counties, charcoal is fed to pigs to keep them healthy, we are dealing not with a scientifically attested hygienic fact but with a survival of a pagan sacrificial rite. The ashes of the notfeuer were spread over fields as a preventive against caterpillars and failure of crops. These ashes were also mixed with the fodder and fed to the cattle. The Christian Easter has supplanted many of the pagan rites of spring, and, therefore, when ashes obtained from fire on Good Friday are spread over trees and animals to prevent lice, and when ashes are thrown into trees on Ash Wednesday; when a twig is cut from every fruit tree on Ash Wednesday, or when fruit trees are whipped on Good Friday, or nails driven into them for the same purpose, these superstitions may likewise be regarded as survivals of old heathen practices.

In another of the sacrifices, particularly that in July, which was more propitiatory in character, the animals selected for the sacrifice were beaten with whips from a sacred tree or bush, intertwined with wild flowers. These twigs and flowers were tied into a sort of brooms which were then tied to the tails of the animals, so that the dew of midsummer night might be collected in their fasces and they thus be endued with greater power. With such a broom the chief herdsman struck the cattle thrice, at the same time reciting a charm. It was thought that in this way all witch. es and disease-bringing spirits could be driven out. At the conclusion of the feasts these brooms were given to the farmers and with them they swept their buildings to rid them 
of all harmful spirits. In Pennsylvania German superstition house and barn are swept on Good Friday to rid them of lice and insure health to the occupants of both. Here the dates do not agree, but the similarity is close enough to warrant us in regarding the superstitions as a survival. The broom plays a very important rôle here, for, while it is on brooms that witches ride through the air, the broom is used as a charm against witches, because of its relation to lightning and thus to Wodan and Donar. The broom is used to thrash bewitched milk and also to discover witches, as no witch will step over a broom.

The holy water of the non-Catholic Pennsylvania German is obtained from the first snow in fall or the last snow in March, and it is good for sore eyes. There is a close connection between March snow water and the celebration in honor of spring. The pagan Germans also had holy water which was taken from the sacred spring after the procession following the sacrificial feast had dropped cakes adorned with flowers into it. This water not only had curative powers but it was used to drive out witches and evil spirits. After the fire had died down everyone rushed into it to search for remains of the sacrificial animals. In their search they had a special predilection for horns and the genitalia of the animals, which were used as charms. This explains why the genitalia of the cow are nailed into the horse stable to keep out witches.

The simulacra consparsa farinae, mentioned in Indiculus Superstitionum 26, have reference to the cakes baked in the forms of various animals. At the several sacrifices, and particularly the Norse jolfest, it was the duty of every one to contribute something, and thus, not having animals to offer, the baked cakes were allowed as substitutes. Here then is the source of the Pennsylvania German Christmas cakes and the Christmas candies, for it is only at Christmas that these distinctive candies can be obtained. That they are usually red is also significant, for red and yellow are the colors of the sun. Nor do the images of lions and other 
animals in any way militate against or disprove the pagan source of the custom. The presence of the five-pointed star among the cakes and the shepherd's crook among the candies illustrates the oft recurring attempt at injecting into a heathen custom a Christian symbolism, and it furthermore affords a striking instance of the union of heathen and Christian elements. To this category belong also the colored Easter egg and the Easter rabbit. The Easter egg with its red or yellow color-all sorts of colors are now common-is the emblem of life, or, as Wuttke puts it, "das sinnbild des neu beginnenden naturlebens." The rabbit, which is supposed to lay these eggs, is the symbol of fertility and as such is sacred both to Ostara, the goddess of spring, and to Hulda or Harke. We can thus see the double significance of the Easter egg. This helps us to understand the superstition that the Easter egg does not rot, why it is used to reduce hernia and, incidentally, also, why so many eggs are eaten on Easter, notwithstanding the price of this staple article of food at Easter time.

In early German times boundary stones were sacred to the gods, and any one who removed such a stone incurred the anger of the gods and could not be received by them. Herein lies the source of the superstition concerning the removal of the boundary stone.

In ancient times the willow was used instead of rope in hanging certain malefactors and in the early Christian church the willow was used to punish those who did not attend early mass on Easter, so that the willow was, and still is, in disrepute, as we may infer from such formulae as these: whipping a child with a willow causes white swelling, or thrashing animals with willows causes œdema.

In early times the implements used by the living were interred with the corpse. The free man was equipped as though going to war; the wife, on the other hand, as though she was going to start married life anew, and therefore she was adorned as a bride. 'This conception still holds in the custom of clothing a wife in her wedding dress instead of a 
shroud, and thus it has, in the folk mind, some remarkable properties, as it is placed under the child's head to cure it of convulsions.

The superstitions concerning spitting in the fire and pointing the finger at a rainbow probably both have their origin in the veneration which the ancient Germans had for the nature elements as manifestations of the gods.

Among the trees sacred to the gods was the elder, consequently it still plays a rôle in superstitions, particularly those concerning medicine.

The superstitions connected with certain days of the week can be traced to the influence which the various Germanic divinities exercised on the popular mind. Thus, a child born on Sunday is lucky because Sunday is named for the sun, the celestial body, which plays the greatest rôle in every primitive religion. The Friday superstitions show greater contrasts than those of any other weekday. Where the pagan conception predominates, Friday is the luckiest of days, because it is the day of Frigg, the Germanic Venus. Therefore it is one of the most favored wedding days, as well as the day on which to begin sowing grain. Where, on the other hand, the Christian influence predominates, Friday is the unluckiest of days, and nothing of importance must be done on the day, not even travelling.

These, then, are a few survivals of Germanic heathendom in Pennsylvania German superstitions, although the list is by no means exhaustive. It might also be interesting to call attention to the content of the superstitions and to show, for example, how custom differs in the several counties in regard to the wedding day or the place of cattle in the moving; or to state that the negation of many of the superstitions is to be found in the same or adjacent counties. Belief in witches has not died out here any more than in Great Britain or Germany, and pow'wowing is still practiced to a greater or less extent. The "himmelsbrief" and its most recent successor, the endless chain of prayer are discussed elsewhere. (cf. Bibliography sub Fogel.) 
Another curious survival of a former period is to be seen in the use of socalled "bēse bicher," such as Albertus Magnus, Egyptische Geheimnisse; Das Sechste und Siebente Buch Moses; Das Achte und Neunte Buch Mosis; and Homann's Der lang verborgene Freund. The last named book, the subject of a very inaccurate article in the Journal of American Folklore, has gone through many editions and is to be found in both English and German versions on the shelves of several bookstores. While these books are consulted by many they are feared by others.

The casual reader will conclude from what has been said in the preceding pages and from the superstitions contained in this volume that the Pennsylvania Germans are extremely superstitious. This assumption is hardly correct. Their superstition has simply not taken a form sanctioned by other strata of society, for, in the last analysis, consulting palmists, fortune tellers and gypsies, spiritualism and Christian Science are no better than superstition.

The problem of translation in the present volume was difficult by reason of the varied tastes and requirements of the reader. The Germanist would probably prefer a translation more nearly literal than that usually given. As the language of the Pennsylvania German is direct, forceful, blunt, and at times coarse, the aim was to reproduce the content of the text rather than its grammar. Very frequently the translations have been toned down to meet the demands of those whose sensibilities might be shocked even in a scientific treatise. This is especially the case with the superstitions dealing with sex and medicine. In the latter case, the flavor of the original is sacrificed for technical correctness, since accuracy of terminology is absolutely essential.

While almost every lexicographer and phonetician has his own system of phonetic notation, the author regrets to have to add another to the already far too numerous sys- 
tems. It is remarkable that Germany with its many dialects and dialect dictionaries has no uniform system of phonetic notation. It is obvious that the presence of so many English words in the Pennsylvania German dialect precludes using any of the German systems, and the fact that the dialect of the present volume is German makes the use of any British or American system impossible, including even the attempt at a system prepared by the American Dialect Society. The systems of Passy, Vietor, Heilig, and Langenscheidt are likewise excluded because they are barely intelligible to a large number of readers of the present volume and are therefore impracticable.

The dialect of this volume is distinctively German and it is essential that German tradition should be followed in the spelling. The English words in the text are spelled according to the same system, however awkward such words may at first appear. The law of assimilation of consonants has been observed and in most cases the etymology of the word has determined its spelling although a few deviations have been deemed advisable, e. g., $\sin$ for sind, $k$ final for $c k, k$, initial for $g e$ (kat $=$ N. H. G. gehabt). Variations in spelling occur because of variation in the usage of individual words. On the whole, consistency has been striven for and in the instances where it has not been attained, the reader will remember that absolute consistency is not possible in any living language. The following characters will be used:

æ Short open $e$, approximating English $a$ in carry; P. G. dærre, wærre.

$\overline{\dddot{\circledast}} \quad$ Long open $e$, as in English bar; P. G. bǣr, wæ̈re, færschte.

e Short close $e$ when used initially or medially, as in English met, bed; N. H. G. fett, bett; P. G. fett, bett. Final $e$ is open, approximating English short $a$, as in P. G. getbe. $e$ is also used to indicate the obscure vowel in vocalic consonants, as in $\mathrm{P}$. G. driber. 
a short open 0 , as in English what, hot; P. G. hąbe, wăs.

å Long broad English $a$, as in English law, broad; P. G. håne, fåre.

a English short $a$ as in English that.

$\overline{\mathrm{e}} \quad$ Long close $e$ as in non-diphthongized English a in hale, mate; N. H. G. sehr, gegen; P. G. sēr, gēğe.

i Short $i$ as in English pin; N. H. G. sind, licht; P. G. sin, lichtel.

I $\mathrm{i}$ in English machine; N. H. G. long $i$ as in mir; P. G. schìr.

o Short $u$ as in English hut; short $o$ in N. H. G. kommen; P. G. hot, gsoffe.

o Long $o$ as in English home; N. H. G. boden, holen; P. G. hōr, höle.

u Short oo in English cook; short $u$ as in N. H. G. hund, kunst; P. G. hund, kunscht.

ù Long 00 as in English pool; long $u$ as in N. H. G. schule, uhr; P. G. schül ür.

au as in English house; N. H. G. haus; P. G. haus.

ei English long $i$ in wine; N. H. G. ei in wein; P. G.wei.

oi as in English toy; M. H. G. heu; P. G. hoi.

b Bilabial stop when initial, surd lenis when final. P. G. butze, schtub.

b Voiced labiodental spirant with same value as English $v$. P. G. gete.

d Dental stop when initial or medial, as in English dare; N. H. G. darf; P. G. dærf, bode. Surd lenis when final, as in N. H. G. tod; P. G. dōt..

f Voiceless labiodental spirant, as in English finger; N. H. G. finger; P. G. finger. 
g Voiced stop, as in English gift; N. H. G. geben; P. G. gebe. When final it is a surd lenis $k$.

$\breve{g}$ Palatal and used only medially, approximating English velar consonantal $i$, and found only in words of German origin containing a medial $g$, as in P. G. ærğel, reğe.

j Voiced front palatal approximating English $y$ in year; as in N. H. G. jahr; P. G. jōr.

k Voiceless guttural stop as in English kin, kill; N. H. G. kater; P. G. kåter.

1 Liquid as in English long; N. H. G. lang; P. G. lang.

m Labial nasal, as in English must; N. H. G. musst, muscht.

n Dental nasal, as in English nut; N. H. G. nüsse; P. G. niss.

ng Guttural nasal, as in English ringer; N. H. G. finger; P. G. finger.

p Voiceless bilabial stop, as in English pain; N. H. G. pein; P. G. pein.

r Cerebral $r$ with slighter trill than is customary in German speech. When final it is almost silent.

s Surd dental spirant, as in English sit; N. H. G. was; P. G. wass.

s Sonant dental spirant, as in English risen; N. H. G. lesen; In the P. G. there is no consistency in the use of surd and sonant s.

sch The thickened sound for N. H. G. initial $s$ consonant: N. H. G. sprache; P. G. schpröch.

t Voiceless dental stop, as in English hat; N. H. G. hut ; P. G. hüt.

w Bilabial spirant, as in English water; P. G. wonse. The labiodental spirant also occurs, the bilabial how. ever predominating. 
x Written for N. H. G. chs, as in N. H. G. wachsen; P. G. waxe.

$z, t z$ Africate dental pronounced $t s$. When medial or final it is written $t z$, as in N. H. G. zehn; P. G. zeee; N. H. G. setzen; P. G. setze.

ch spirant, front or velar, as in N. H. G. ich, ach; P. G. ich, ach. 


\section{BIBLIOGRAPHY AND ABBREVIATIONS}

A A

Af

A J

A J F

A J H S

Alem

A M

A S

Be

B D V

B F

Bl N R

B M

$\mathrm{Br}$

Allerlei Aberglauben. Erfurt.

All of the fourteen Pennsylvania German counties of Pennsylvania.

Hlois John. Sitte, Brauch und Volksglaube im Deut. schen Westböhmen. Prag 1905.

Journal of American Folklore. Boston 1888.

Publications of American Jewish Historical Society. Vol. 9. 1901.

Alemannia. Zeitschrift für Alemannische und Fränkische Geschichte, Volkskunde, usw. Freiburg 1873.

Albertus Magnus. Bewährte und approbirte sympathetische und natürliche Egyptische Geheimnisse für Menschen und Vieh. Zwanzigste vermehrte und verbesserte Auflage. Toledo.

Anton Birlinger. Aus Schwaben. 2 vols. Wiesbaden 1874.

Berks County.

II. Busch. Deutscher Volksaberglaube. Leipzig 1877.

William George Black. Folk-Medicine; a Chapter in the History of Culture. London 1883.

Richard Blakeborough. Wit, Character, Folklore and Customs of the North Riding of Yorkshire, with a Glossary of over 4000 Words and Idioms now in Use. London 1898.

Karl Bohnenberger. Mitteilungen über Volkstïmliche Ueberlieferungen in Württemberg. Stuttgart 1904.

Popular Antiquities of Great Britian Comprising No. tices of the Moveable and Immoveable Feasts, Customs, Superstitions and Amusements, Past and Present. Edited from materials collected by John Brand, F.S. 
A., with very Voluminous Corrections and Additions by W.. Carew Hazlet. London 1870.

Bro

C. F. Brown. Hohman's Long lost Friend. Journal of American Folklore. 17, 89-152.

B S

Baltische Studien. Vol. 33. Stettin 1883.

$\mathrm{Bu}$

Bucks County.

$\mathrm{C}$

Carbon County.

C F

County Folk-Lore. London 1895.

C F Gl

E. S. Hartland. Gloucestershire Folk-Lore. London 1892.

C F L \& R C. J. Billson. Leicestershire and Rutland Folk-Lore. London 1895.

C F Nu M. C. Balfour. County Folk-Lore Concerning Northumberland. Edited by N. W. Thomas. London 1904.

C F Suf Lady E. C. Gurdon. County Folk-Lore of Suffolk. London 1893.

C F Y E. Gutch. Folk-Lore Concerning the North Riding of Yorkshire, York and the Ainsty. London 1901.

Corn

M. A. Courtney. Cornish Feasts. Penzance 1890.

C P \& P Credulities Past and Present.

C S A F. D. Bergen. Current Superstitions collected from the oral Tradition of English speaking Folk. Boston 1896.

D Dauphin County.

Da W. Dawson. Christmas: Its Origin and Associations. London 1902.

D E C P. H. Ditchfield. Old English Customs Extant at the Present Time. An Account of Local Observances, Festival Customs and Ancient Ceremonies yet Sur. viving in Great Britain. London 1896. 
Den

D Eng:

D M

Dr

D Scot

Dy

Enc S

Ett

Etl

E Y

$\mathrm{Fa}$

F B

Fo

F R

Fr

G

The Denham Tracts. A collection of Folklore by $\boldsymbol{M}$. A. Denham, and Reprinted from the original Tracts and Pamphlets printed by Mr. Denham between 1846 and 1859. Edited by Dr. James Hardy. London $1892 ; 1895$.

T. F. T. Dyer. English Folk-Lore. 2nd edition, revised. London 1880.

Zeitschrift für Deutsche Mythologie. Göttingen 1853.

Paul Drechsler. Sitte, Brauch und Volksglaube in Schlesien. Leipzig 1905.

John Graham Dalyell. The Darker Superstitions of Scotland. Illustrated from History and Practice. Edinburgh 1834.

T. F. T. Dyer. Domestic Folk-Lore. London 1881.

Encyclopedia of Superstitions, Folklore and the Occult Sciences of the World. Edited by Cora Luise Daniels and Prof. C. M. Stevans. 3 vols. Chicago and Milwaukee 1903.

Ettenheim.

Ettlingen.

John Nicholson. Folk-Lore of East Yorkshire. London 1890.

A. B. Faust. The German Element in the United States With Special Reference to its Political, Moral, Social and Educational Influence. Boston and New York 1909.

Folk-Lore. A Quarterly Review of Myth, Tradition, Superstition and Custom. London 1883-1889.

E. M. Fogel. The Himmelsbrief. German American Annals. N. S. 6. $286 \mathrm{ff}$.

Folk-Lore Record. London 1878-1882.

Freiburg i. B.

Jakob Grimm. Deutsche Mythologie. 4. Ausgabe. Berlin 1878. 
Q A Germanistische Abhandlungen herausgegeben von Karl Meinhold. Breslau 1882.

Gael

Daniel Deeney. Peasant Lore from Gaelic Ireland. London 1900.

Gol W. Golther. Handbuch der germanischen Mythologie. Leipzig 1895.

Göp

Göppingen.

G R

Die gestriegelte Rockenphilosophie, oder aufrichtige Untersuchung derer von vielen superklugen Weibern hochgehaltenen Aberglauben. Chemnitz 1759.

G Scot Walter Gregor. Notes on the Folk-Lore of the NorthEast of Scotland. London 1881.

$\mathrm{H}$

Sarah Hewett. Nummits and Crummits. Devonshire Customs, Characteristics and Folk-Lore. London 1900.

Hlbg

H M

H N C

Heidelberg.

Hans Meyer. Das deutsche Volkstum. 2. Ausgabe. Leipzig 1903.

William Henderson. Notes on the Folk-Lore of the Northern Counties of England and the Borders. London 1879.

Ho

Die Land- und Haus-Apotheke, oder getrever und gründlicher Unterricht für den Bauer und Stadtmann, enthaltend die allerbesten Mittel, sowohl für die Menschen als für das Vieh besonders für die Pferde. Nebst einem grossen Anhang von der Aechten Färbe. rey, um Türkisch-Roth, Blau, Satin-Roth, Patent-Grün und viele andere Farben mehr zu Färben. Erste Amerikanische Auflage. Herausgegeben von Johannes Georg Homan, in Elsasz Taunschip, Berks Caunty, Pennsylvanien. Reading: Gedruckt bey Carl A. Bruckmann, 1818.

Höf M. Höfler. Volksmedizin und Aberglaube in Oberbayern. Neue Auflage. München 1893.

Hoh Der lange Verborgene Freund, oder: Getreuer und 
christlicher Unterricht für jedermann, enthaltend wunderbare und probmäszige Mittel und Künste, sowohl für die Menschen als das Vieh. Mit vielen Zeugen bewiesen in diesem Buch und wovon das mehrste noch wenig bekannt ist, und zum allerersten Mal in Amerika im Druck erscheint. Herausgegeben von Jo. hann Georg Hohmann, Nahe bey Reading, in Elsasz Taunschip, Berks Caunty, Pennsylvanien. Reading: Gedruckt für den Verfasser. 1820.

Ir

Lady Wilde. Ancient Legends, Mystic Charms and Superstitions of Ireland. With Sketches of the Irish Past. London 1887.

J G A Ulrich Jahn. Die deutschen Opfergebräuche bei Ackerbau und Viehzucht. Breslau 1884.

Jo

Amandus Johnson. The Swedish Settlements on the Delaware. Their History and Relation to the Indians, Dutch and English, 1638-1664. 2 vols. Philadelphia 1911.

$\mathrm{Kl}$

Kaiserslautem.

L

Felix Liebrecht. Zur Volkskunde. Alte und neue Aufsätze. Heilbronn 1870.

$\mathrm{Lb}$ Lebanon County.

Lh Lehigh County.

Lnc Lancaster County.

Lust Lustnau.

L $V \quad$ G. Lammert. Volksmedizin und medizinischer Aber. glaube in Bayern. Würzburg 1869.

M D L M. D. Learned. Pennsylvania German Dialect. Baltimore 1889. The American Ethnographical Survey. Americana Germanica, vol. 12.

M D V E. H. Meyer. Deutsche Volkskunde. Strashurg 1898. Monroe County.

Mit

Montgomery County. 
$\mathrm{Na}$

Neust

N Scot

Nürt

R A

Sc

$\mathrm{S} \& \mathrm{C} \mathrm{S}$

Se

S H S

$\mathrm{Sn}$

St

S V

$\mathrm{Sw}$

V. A S

V S L
Northampton County.

Neustadt a. d. H.

James Napier. Folk-Lore: or Superstitious Beliefs in the West of Scotland within this Century. Paisley 1879.

Northumberland County.

Nürtingen.

Richard Andree. Braunschweiger Volkskunde. Braun. schweig 1896.

Schuylkill County.

Strange and Curious Superstitions and Customs. London 1891.

O. Seidensticker. Die erste deutsche Einwanderung in Amerika. Philadelphia 1883.

J. G. Campbell. Superstitions of the Highlands and Islands of Scotland. Glasgow 1900.

Snyder County.

Stuttgart.

Mitteilungen der schlesischen Gesellschaft für Volks. kunde. Leipzig 1901.

Swabian.

Anton Birlinger. Volkstümliches aus Schwaben. 2 vols. Freiburg 1862.

Vincent Stuckey Lean. Lean's Collectanea. Collections of Proverbs, Folk-Lore and Superstitions, also Compilations towards Dictionaries of Proverbial Phrases and Words Old and Disused. 4 vols. Bristol 1902-1904.

W

H. von Wlislocki. Volksglauben und religiöser $G_{e}$. brauch der Magyaren. Münster i. W. 1893. 
W Ir Lady Wilde. Ancient Cures, Charms and Usages of Ireland. Contributions to Irish Lore. London 1890.

W Sus West Sussex.

$\mathrm{Wu}$

A. Wuttke. Der deutsche Volksaberglaube der Gegenwart. Dritte Bearbeitung von Elard Hugo Meyer. Berlin 1900.

$\mathbf{Y}$

York County.

Z Ignaz v. Zingerle. Sitten, Bräuche und Meinungen des tiroler Volkes. Zweite vermehrte Auflage. Innsbruck 1891.

Z f D M Zeitschrift für deutsche Mythologie. Göttingen 1853.

Z f V Zeitschrift des Vereins für Volkskunde. Berlin 1891. 



\section{CHILDHOOD}

1. Mer såkt ạls schlechte kinner wæ̈re ime schlechte zēche geböre. $(C, D . L b, L n c . M r, N a, S c, Y)$

It is said of bad ehildren that they were born under an evil star.

Von bösen kindern sagt man, sie seien unter einem schlechten sterne, in einem bösen zeichen geboren. $Z \mathbf{5}$

2. W̄̄r im Jener gebōre is kạnn geschpuker sēne.

A person born in January can see ghosts.

3. En kind wū uf der ērscht Aूbril gebōre is lëbt net lăng. $(L b)$

A child born on April 1 will not live long.

Aprilkinder sind unglückskinder. $W u 85$.

4. Wǣr im Moi gebōre is wært net alt. $(N u)$

A child born in May will not live long.

Kinder, die am 1. Mai zur welt kommen, gehören den hexen. $D r 184$.

5. En kind in der Wōk gebōre grikt hautgrankete. $($ Lnc, $Y$ )

A child born in Libra will have skin diseases.

....... ist ein waghals, probiert alles und hat glück dabei. Hlbg.

6. En kind im Lēb gebōre wært schtærik. $(C, D, L b$, Lnc, $M r, S c, S n y, Y$ )

A child born in the sign of Leo will become strong.

Wenn ein kind im zeichen des Löwen geboren ist, wird es sehr stark. $Z 3$

7. En kind in der Jungfrau geböre is gliklich. (D, Lnc, Sc, Sn, Y; Heidelberg)

Lucky the child that is born in Virgo.

8. En kind im Grebs gebōre kummt net gut å in der welt ( $L n c, S c)$ oder gēt zurik'zus. $(C, D, L b, M r, S n, Y)$ 
A child born in the sign of the Crab will not prosper, or it will decline.

Kinder, im zeichen des Krebses oder des Skorpions, "der rauhen dinger" geboren, sind unglücklich und kommen in der welt nie recht fort. $W u 87$.

A child born under the Crab will not do well in life. DY 143.

9. W̄̄r im Schtîr gebōre is gebt en schtærkopp. (Af)

Any one born in the sign of Taurus will be stubborn.

Im Stier geboren wird das kind halsstarrig und ein dickkopf. $W u 88$.

10. Wǣr im Fisch gebōre is is immer dærschtich. $(B u)$

A man who was born in the sign of Pisces is always thirsty.

Wer im zeichen der Fische geboren ist, wird ein trinker. $W u 88$.

11. Kinner uf der Gwatem'ber gebōre kenne gschpuker sēne. $(B e, C, L n c, M r, N a, Y)$

Persons born on Emberdays can see ghosts.

Kinder, die im Quatember geboren sind, sehen geister. Z 4

12. En Sunndåkskind wært schtolz. (Af)

A child born on Sunday will become proud.

Wer an einem Sonntag geboren worden, ist ein glückskind. $Z f D M 1.235$

Born on Sunday, you will never want. $C P \& P 499$

13. En Sunndåkskind wært bątzich. $(C, Y)$

A child born on Sunday will become saucy.

Es hot immer bissel en hochmut. Hlbg.

14. En Mittwochskind hat ken gūter kopp fer lærne. $(C, M r)$

Any one born on Wednesday will be stupid.

Born on Wednesday, sour and sad. $C F \& P 499$

15. En Mittwochskind lēbt net lạng. (Be, D, Lb, Lh, Lnc, $M t, N a, N u, S c, Y$ )

A child born on Wednesday will not live long. 
16. En Sămschdåkskind wært en schlạpp un muss immer schạffe. $(B e, B u, C, D, L b, L n c, M t, N u, Y)$

A child born on Saturday will be slovenly and must work for a livelihood.

Saturday's child works hard for his living. $D Y 2 ; C P$ d. $P 499$

17. En kind as Sánschdåks uf di welt kummt eb di æ’'rbet gschafft is gebt en schläpp. ( $Y$ )

A child born on Saturday before the daily routine work is done will be slovenly.

18. En kind as der dreizēt gebōre is hot ken glik. (Af)

Unlucky the child that is born on the thirteenth of the month.

19. Kinner wū uf der siønunzwann'zigscht September gebōre sin gleiche di weibsleit un schtærik drinke. $(D)$ Children born on September 27 will be fond of women and strong drink.

Der 27. September ist ein unglückstag. Hlbg.

He was born in August, a periphrasis for a liquorish person. $V S L 2,111$.

20. Wạnn en kind uf di welt kummt wannn en gewitter am himmel schtēt wærts dōd gschlăğe fume gewitter. (Be,Lh;Heidelberg)

A person born during a thunderstorm will be killed by lightning.

21. En kind muss 's ērscht mōl an der mutter îre rechte bruscht drinke, nō wærts net links. ( $M t)$

A child must receive its first nursing at the right breast so that it will not become lefthanded.

Wird das kind zuerst an die linke brust gelegt, so wird es linkshändig. $B M 18$

22. En kind mit zwē hōrwærb̄el oder kî'schlek gebōre wært gscheid. $(C, D$. Lnc,$Y)$

A child that is born with two cowlicks will be bright.

Hat das kind zwei haarwirbel, wird es ein kluger mensch.

$Z 13$ 
23. Zwẽ hör'wærtbel uf me kind seim kopp bedeite as es gscheit wært. $(C, D, L n c)$

Two cowlicks on a child's head are a sign of brightuess. Hat das kind zwei haarwirbel, wird es ein kluger mensch. Z 13

24. En kind mit zwē hōrwærbel kummt weit rum in der welt. $(L n c)$

A child with two cowlicks lives in two kingdoms. $C S A 12$ Hat das kind zwei haarwirbel, wird es ein kluger mensch. Z 13

If a child had two "crowns" on his head, it was a sign that he would eat his bread in two kingdoms. $F B 12,75$

25. En hōr'wærbel uf me kind seim kopp bedeit as es en schtoђ'richer mensch gebt. ( $B u, C, D, L n c, M t, M r$, $\mathrm{Na}, \mathrm{Nu}$; Heidelberg)

A cowlick on a child's head is a sign of a stubborn disposition.

26. En hōr'wærbel uf me kind seim kopp bedeit en schtæ'riğer mensch. $(B u)$

A child born with a cowlick will become very strong.

27. Wann en kind gedåft wært gebt merm pår leffel foll dåfwasser, nō kanns leicht lærne un gebt en æriğer singer. (Be, C, D, Lb, Lh, Lnc, Na,Sc,Sn)

When a child is baptized it is given a few teaspoonfuls of baptismal water, so that it may be bright and a good singer.

Soll ein kind schnell lesen lernen, so gibt man ihm von seinem ersten badewasser zu trinken. $Z f d M 4.2$

28. Wạnn en kind gedåft wært gebt em di mutter alsemōl' fum dåfwasser, so ans es ken heilschpells grikt. (Be, $C, D, L h, M r, N u, S c, S n)$

The water used in baptism is sometimes given as a cure for crying spells in ehildren.

Das gebrauchte taufwasser gilt als heilkräftig. $B \quad M \quad 24$ Water that has been used at the baptismal rite was regarded as a preservative against witcheraft and was employed for various disorders. $D y 20$ 
29. Wạnn en kind gedåft wært gebt di mutter 'm àlsemōl' en leffel foll dåfwăsser, so ans es kind net hært zånt. $(C, L b, S c, S n)$

After baptism the mother sometimes gives the child a teaspoonful of the baptismal water to help it teethe.

Die hebamme taucht heimlich den finger ins taufwasser und reibt damit das zahnfleisch des kindes, so zahnt es leicht. $W u 390$

Wash out the mouth of the recently regenerated infant with the remaining sanctified water as a safeguard against toothache. C F Glou 1. 53.

30. En kind às der recht nåme net grikt wăns gedåft wært lēbt net lạng. $(B e, L b, L h, M t)$

If in baptism the child does not receive the name intended for it, it will not live long.

If a child is not given the name which was decided on by the parents before the birth of the child, the child will not live long. $B l N R 114$

Wenn das kind nicht richtig getauft, $d$. $h$. wenn in den taufformeln ein versehen gemacht wird, so muss der mensch zeitlebens als plagegeist umherirren, besonders als alp die menschen in der nacht plagen. W 390 .

31. En grankk kind wært gråd besser wanns mol gedåft is. $(B e, B u, L h, L n c, M t, N a, S c, Y)$

A sick child will improve immediately after its baptism. Ein krankes kind kann man oft durch die taufe vom tode retten. $Z f d M 4.2$

A child never thrives until after baptism. $H N C 15$

32. Wạmmer gfrōkt wært en kind iøer dåf zu hēந̄e un såkts a ab såkt mers glik a $\mathrm{b}$. (Lh)

To decline to act as sponsor at a baptism will bring misfortune.

33. Me kind dærf mer net der nåme geђ̄e fun leit ăs schun aus der familie gschtærbe sin, oder es wært net alt. (Af)

A child must not be named after a deceased member of the family, or it will not live to be old. 
Kindern darf man nicht die vornamen von bereits verstorbenen personen der familie geben, sonst werden sie nicht alt. $B S 33.115$.

34. En kind ăs E'få gidåft wært lēbt net lạng. (Lh)

If a child is christined Eve, it will not live long.

Sollen kinder lange leben, lasse man die söhne Adam, die töchter Eva nennen. G 3. 26

35. Wạmmern kind seim fạder oder mutter nōnåmt is es's letscht ass kummt. ( $B u, L b, M r, M t, N a, S n, Y)$

There will be no more children in a family after one of them has been named for its father or mother.

36. Wạmmern kind seim fạder oder mutter nōnåmt lēbts net ląng. $(C)$

$A$ child named for its parents will not live long.

Wenn die kinder der eltern namen bekommen, sterben sie eher als die eltern. $G R 45$

37. Wesch en kind mit dåfwassser uns grikt en schēni haut. (Be, Lb, Lh, Lnc, Mt, Na, Nu, Sc, Sn; Heidelberg) Wash a child with the water of baptism and it will have a beautiful complexion.

38. Wạmmer en wìk zu zwet scho'kelt, waxts kind å . (Af) If two persons rock a cradle the child will be livergrown.

39. Wạmmern lēri wikk schokelt waxxts kind å . (Af)

If you rock an empty cradle, the child will be livergrown. Zwei sollen nicht an einem kinde wiegen, es kommt dadurch aus seiner ruhe. $G 3.267$

40. Wạmmern lēri wîk scho'kelt schtēlt merm kind der schlö. (Lnc, $N u, S c, S n, Y)$

If you rock an empty cradle, you will rob a child of its sleep.

Wenn man eine leere wiege schaukelt, stiehlt man dem kinde dem schlaf. $Z 26$

41. Wămmern lēri wtk schokelt grikts kind bauchwē. (D, Lnc, $M r, M t, N a, S c, S n, Y$ ) 
If the empty cradle be rocked, the baby will have colic. $C S A 50$

Wenn man eine leere wiege schaukelt, bekommt das kind, welches sonst darin liegt, bauchweh. $Z 25$

42. Wammern le'ri wik schokelt nemmt merm kind di rū. $(L b, M r, S n, Y)$

If you rock an empty cradle, a child cannot rest.

Eine ledige wiege soll niemand wiegen, sonst wiegt man dem kind die ruhe weg. $G 3.22$

43. Mer dærf net it'ern kind schritte wannns uf em bo'dem oder grund leit, oders waxt net. $(A f)$

Stepping over a child which is lying on the floor or ground will retard its growth.

Wenn kinder auf der erde liegen und man schreitet über, sie hinweg, so bleiben sie sofort im wachstum stehen. $B S 33.115$

44. Di mutter muss trm kind 's ērscht pres'ent gebe. (Bu. $M t$ )

The mother should give her child its first present.

45. Me kind sei peter muss ems ērscht pres'ent geђe. (Be, $L b, L h, L n c, N a, N u, S n ; H$ eidelberg)

The godfather should give the first present to his godchild.

46. Di gōd un der peter solle me kind 's ērscht buch kåfe, nō lærnts gūt. $\quad(B e, C, D, L b, L h, L n c, S n ; H e i d e l$ berg)

A child will be a bright pupil in school if the sponsors buy its first book.

47. Wạnn en kind en jōr alt wært gebt merm en buch, nō wærts gscheit. ( $B e, C, D, L b, L h, L n c, M r, N a, N u$, $S n, Y^{\prime} ;$ Heidelberg)

If a child is given a book when it is a year old it will be bright.

48. En jung bobl lëkt mer net uf di links seit schunscht wærts links. $\quad(B u, D, L b, L h, L n c, M t, S n)$

A child will be left handed if it is laid on the left side: 
Ein neugeborenes kind darf man nicht auf die linke seite zuerst legen, sonst wird es linkshändig. $B S 33.116$

49. En kind soll net schmąke ebs en jōr ąlt is oders schmakt nt net. $(L b)$

A child should not smell at anything before it is a year old or it will never have a sense of smell.

Riecht ein kind vor dem ersten jahr an etwas, so lernt es hernach nicht riechen. $G$ 3. 277

50. Kinner in bruns wesche macht si schē . (Be, Lnc, Mt, $N a, Y ;$ Neustadt)

Washing children with urine makes them handsome.

51. Kinner soll mer di schtēk nuf grạdle losse, nõ gețe si grōsse leit in der welt. $(B u, L b, M t, S n ; H e i d e l$ berg)

Permit children to erawl upstairs and they will be illustrious.

52. En kind muss mer nunnernemme eb mers nuf nemmt, nō wærts reich. $(D)$

A child will become rich if it is earried down stairs before being carried up stairs.

53. Mer muss en kind der ërscht dåk ąs es gebōre is uf der eђ'erscht schpeicher nemme un zum fenschter nausguke losse, nō gebts en å gsēn'ener mensch. ( $D ;$ Kaiserslautern)

A child should be carried to the garret on the day of its birth and allowed to look out of the garret window, then it will become a respected citizen.

54. Mer muss schnell mit me junge kind di schtēk uf un a b schpringe, no wærts flink. ( $B e, L h, L n c, M r, N a, S c)$ Run up and down the stairs with an infant and it will become spry.

Der jüngste pate nimmt das kind an der haustür und läuft damit schnell nach der stube zur mutter, so wird das kind schnell. $W u 390$

55. Fn kind ąs net 's ērscht di schtēk nuf gedråge wært 
kummt net noch em himmel. (Lb,Lh, Lnc, Mt, $S n, Y$ )

If a child is not carried upstairs before being carried down stairs it will not go to heaven.

56. En kind às net 's ērscht di schtēk nuf gedråğe wært emaunt' zu nix. (Bu)

If a child is not carried up stairs first it will never amount to anything.

57. En kind wært net âlt wạnns net 's ērscht di schtēk nufgedråğe wært. $(\mathrm{C}, \mathrm{Na})$

A child will not live long unless it is carried upstairs before being carried down.

Es stirbt. Hlbg.

58. Mer muss en kind en schtok hēcher nufnemme ob mers nunner nemmt so às es in di hē kummt. ( $B e, B u$, $L b, L h, N a, S c)$

Carry a child up stairs before carrying it down stairs so that it may rise in the world.

A child should go up in the world before it goes down, else it will never rise in after-life either to riches or distinction. $D Y 8$

59. Mer muss en kind en schtok hēcher nuf nemme eb mers nunner nemmt so a s es höch singt. ( $B e, B u$, $L b, L h, L n c, N a, N u, S c)$

In order that a child may be able to sing high notes it should be carried up stairs before it is carried down stairs.

60. Wămmers ērscht en kind en schtok hēcher nuf nemmt wærts gscheit. $(B e, B u, L b, L h, N a, S c)$

If a child is carried up stairs first it will becorne quickwitted.

61. Wămmern kind 's ērscht en schtok hēcher nufnemmt wærts ei 'bildisch. $(D, L b, L n c)$

If a child is first carried up stairs it will become conceited and vain. 
62. En kind wært schtolz wammer 's ërscht en schtok hēcher drecht. $(C)$

A child will become proud if it is first carried up stairs.

63. Wammern kind net 's èrscht nufnemmt muss mers èrscht nunner nemme. (Be, Bu, Lb, Lh, Na)

A child will die in infancy if it is not immediately after birth carried upstairs.

64. En kind dǣrf mer net aus em haus nemme bis es gedåft is. $(A f)$

Never take a child from home before it is baptized.

Ein ungetauftes kind darf nieht aus dem hause getragen werden. $\operatorname{Dr} 188$

65. Mer soll en kind net in der schpiğel guke losse ebs en jōr alt is oders wært schtolz. (Af)

If a child is permitted to look into a mirror before it is a year old it will become proud.

Lässt man das kind unter einem jahr in den spiegel sehen, so wird es eitel und stolz. $G 3.29$

66. Wạnn fîl leit en kind å guke wạnns gedåft wært is es leicht verhext. (Bu, Lnc, Mr, Mt, Sn)

If many look at a child while it is being baptized, it is easily bewitched.

Wenn viele leute das kind bei der taufe ansehen, wird es leicht vermeint. $Z 14$

67. Mer muss me kind recht tschul'eri å henke, so ąs es en hōcher gēscht grikt. $(L h, N a, S c)$

A child must be decked with jewelry, so that it may become highminded.

68. Me kind muss mer recht tschü'elri å henka as es zu ebbes kummt in der welt. ( $L h, N a, S c)$

A child must be decked with .jewelry, if it is to amount to anything in the world.

In den ersten bad des kindes wird ein goldstück getan, damit es dem kind nie im leben an geld fehle. $H$ M 1. 277 
69. Henk me kind recht tschu'elri $\mathrm{a}^{\sim}$ so as es reich wært. $(B e, L b, L h, M t, N a, S c)$

Adorn a child with jewelry and it will become rich.

Das kind darf vor der taufe kein geld sehen oder goldschmuck tragen, sonst wird es habgierig. $W u 391$

70. En kind gebōre mit der nat’elschnūr um der hạls gebt en grōsser pạp'lærer maxnn. $(C)$

If a child is born with the umbilical cord about its neck, it will become great and popular.

71. En kind wū en gūter singer is gebt en engel, s' wært net alt. (Bu;Heidelberg)

A child that sings very well will become an angel, it will not live to be old.

72. Mer dærf en kind net dåfe losse uf der dåk ąs en leicht in der gmē is. $(N a, Y)$

A child should not be baptized on a day when there is a funeral in the congregation.

Unmittelbar nach einer leichenbestattung soll man nicht taufen lassen, sonst folgt das kind dem toten nach. G 3. p 489

73. Me kind wanns uf di welt kummt muss mern alti windel $\AA^{\sim}{ }^{\prime}$ ū $\bar{u}^{\sim}$ oders gebt en dib. (Bu; Heidelberg)

If an old diaper is not put on a newborn child, it will become a thief.

74. Me kind sei ërschti windel soll mer ferbrenne fer glik. (Be, Bu, Lb, Lh, Lnc, Mt, $Y$; Kaiserslautern)

Burn the first diaper of a child for luck.

75. Wạnn en mutter îr kind net zu sēne grikt uf der dåk wūs uf di welt kummt libt sis net. (Lnc)

A mother will never love the child she is not permitted to see on the day it was born.

Wenn eine mutter das neugeborene kind am ersten tage nicht $\mathrm{zu}$ gesichte bekommt, wird sie es nie lieben. $\quad \boldsymbol{Z} 9$

76. Wann granke kinner mit gold schplle wærn si wider gsund. (Lnc) 
If sick children play with money they will recover.

Wenn kranke kinder mit geld spielen, genesen sie. $Z 62$

77. Me kind dærf mer nix schtærğes zu drinke gebe ebs en jōr alt is oders waxt nimmi. $(B u)$

Giving a child strong drink before it is a year old will stop its growth.

Kindern und jungen hunden soll man keinen schnapps zu trinken geben, weil sie nachher nicht mehr wachsen. V A S 1. 487

78. Wann en kind ebber nōgenånt wært muss sell em en frak kåfe. $(B e, L h)$

The person for whom a child is named must buy it a dress. Die gotte hat in früheren jahren ihrem täufling am Klosentag ein "hemdle" geschenkt. A S 1. 391

79. Wạmmern kind kitzelt ebs en jōr ąlt is wærts schtot'terich. (Af; Heidelberg)

A child will stammer if it is tickled before it is a year old.

80. Di èrscht laus wū mær uf me kind seim kopp finnt ferdrikt mer uf em gsangbuch, nō gebts en gūter singer. $(D, L h, L n c, N u)$; uf der bîbel, nō wærts gscheid. (Lh)

The first louse found on a child's head should be crushed on the hymnbook and the child will become a good singer.

Die erste laus an einem kinde muss man auf dem gesangbuch knicken. Dann lernt das kind recht singen. Alem 27. 229

81. Me kind soll mer di hōr net schneide ebs en jōr alt is oder si falle aus. $(B u)$

A child's hair will fall out if cut before it is a year old. ....Sie wachsen schlecht und sind immer dünn. Hlbg.

82. En kind wært net alt wainmers schērt ebs en jōr alt is. $(B e, B u, C, L h, L n c, M r, N a, S c, Y$ )

If a child's hair is cut before it is a year old it will die young.

83. De kinner solle di hōr net abgschnitte wære eb si en jōr 
alt sin oder si wære schwąch. (Be, $C, D, L b, L h$, $L n c, M t, N a, N u, S c, Y$ )

Children will be weaklings if their hair is cut before they are a year old.

Schneidet man einem kinde vor dem siebenten altersjahr die haare ab, so kann es nie zu vollkommenen kräften kommen. $Z$ f $d M$ M. 3

84. En weibsmensch as ufgebindelt is dærf en kind net schēre oder's lēbt net lạng. (D, Lh, Lnc; Heidelberg)

A child will not live long if its hair is cut by a pregnant woman.

85. Mer soll en kind bei nímand altes schlöfe losse, schunscht schtærbts zēe jōr jinger. $(B e, B u, C$, $D, L b, L h, L n c, M r, N a, S c, Y)$

Permitting a child to sleep with an old person shortens its life by ten years.

Es ist eine fast allgemeine meinung, dass kinder nicht von alten leuten geliebkost werden und nicht mit ihnen zusammen schlafen sollen. $W u 386$

86. Wạmmern kind schlecht ebs en jōr allt is wærts schtotterich. $(\mathrm{Be}, \mathrm{Na})$

A child that is whipped before it is a year old will stam. mer.

87. En kind d̄̄rf mer net hake ebs en jōr a्रlt is oder di schlēk bạt nōchhǣ̄r nix. (Af)

If a child is whipped before it is a year old later punishment will be futile.

Kinder unter einem jahre schlage man nicht, sonst werden sie hartschlägig. Alem. 27. 229

88. Wạmmer ausfinne will wạs færn hạndwærik oder gscheft âs en kind sich mol wēlt lēkt mer en schtik geld, en btbel, en schtik handwærksgschær un en bottel ht'. Des wū's denō' langt gebt sei`hąndwærik. Wąnns âter noch der bottel langt gebts en sifer. ( $B e, B u$, $D, L b, L h, L n c, M r, M t, N a, Y)$ 
To ascertain the occupation of the future man place before the child a coin, a bible, a tool and a bottle. Whichever the child takes up first will be its future oc. cupation. If it however reaches for the bottle it will become a drunkard.

Wonach das kind zuerst greift, das zeigt seine künftige lieblingsbeschäftigung an. $G 3 . \mathrm{p} 488$

89. Wanmmern kind zum fenschter aus un nei gradle losst gebts en díb. (Af; Heidelberg)

If a child is permitted to crawl in and out through a window it will become a thief.

90. Wanmmern kind zum fenschter naus'grådle losst wąxts nimmi. (Af)

If a child is permitted to crawl out of a window it will stop growing.

Man soll ein kind nicht zum fenster hinausheben, sonst wächst es nicht. Alem. 27. 229

91. En kind a sis sich fïl brecht wax gũt. $(D, L n c, Y)$

If a child vomits frequently, it will grow rapidly.

Speikindel, gedeihkindel. $D r .210$

92. Wąnn der dokter 's kind $\AA^{\sim \prime d u t ~ w a ̆ n n s ~ u f ~ d i ~ w e l t ~ k u m m t ~}$ muss er acht gebe as er nummejō' 's kind mit em rechte årm 's ērscht ins hemmli schluppe losst. ( $B u$; Heidelberg)

When dressing a newborn infant the doctor should take care to put the child's right arm into the sleeve first.

93. Mit wellre hañd âs en bobbel 's ērscht mol 's ërscht in di glëder schluppt weisst ebs rechts oder links wært. (Be, Bu, Lb, Lnc, Mt, Sc; Heidelberg)

The hand with which a child that is being dressed for the first time slips into its clothing shows whether it will be right handed or left handed.

94. En kind sott mit em rechtse årm 's ērscht in der hemmærmel schluppe. (Bu, C; Heidelberg)

Put a child's right arm into the sleeve of its gown before the left. 
95. Mer solls net fær me jōr uf en kind reğ'ere losse, es grikt sunnefleke. $(L b)$

If it rains on a child less than a year old, it will be freckled.

Wird ein kind, ehe es ein jahr alt ist, beregnet, so bekommt es sommersprossen. $V A S 1.486$

96. Mer solls net uf kinner reğ'ere losse oder si griłge summerfleke. (Af)

If it rains on a child the child will be freckled.

97. En å 'gewaxe kind schmirt mer mit gensfett.

A livergrown child should be rubbed with goosegrease.

98. En å 'gewaxxe kind lēkt mer uf di dire schwell un messts. Wanns mol iber sell mōs naus gewąxe is, waxts nimmi å . $(L n c, M r, Y)$

Lay a livergrown child on the door sill and measure it. As soon as it has outgrown this measure, the complaint will cease.

99. En kind âs unner me riğel, schtrik oder so ebbes dærich schluppt waxt net. (Be, Bu, Lb, Lnc, Mt, Y)

If a child crawls under a rope, bar, etc., it will not grow. Man soll das kind nicht unter etwas durchschlüpfen lassen sonst wächst es nicht. Alem 27. 229

100. Mer soll me kind geђe fun allem was mer selber esst, schunscht mącht merm sei ${ }^{\sim}$ hærz blūte. $(C, L n c$, $S n, Y)$

Refusing to share with your child everything you eat will make the child grieve.

Einem kleinen kind soll man von allem, was man in seiner gegenwart isst, etwas geben, sonst blutet ihm das herz. $Z 60$

101. En hüfeise wū âll di neğel noch drin sin me kind in di schokel gelēkt halts kind gsund. (D)

Place a horseshoe with all the nails in it into a child's cradle, and the child will always be hale and hearty.

Auch den kindern wird ein gefundenes hufeisen in die wiege gelegt. $W u 130$ 
102. Wạmmern Sunndåkskind an der schpiğel hëbt waerts schtolz. (Lb, Lnc, $Y$; Heidelberg)

Let a child born on Sunday look into a mirror and it will become proud.

103. Der ērscht fråk ąs en kind å grikt dærf ken alter sei schunscht wærts en schlapp. (Be,Lb,Lh,Lnc, Mr; Heidelberg)

If the first dress put on a child is not a new one, it will become a slattern.

104. En kind ass zwē jör ạlt is is hạlb so lang ås es waert. $(B u)$

A child at the age of two has attained half its height.

......Drei jahre..... Hlbg.

105. Wạmmerme kind 's ērschtmol di schtrimpelcher $\mathfrak{a}^{\sim}$ dut, muss merm 's rechts 's ērscht å dū , oders wært links. (Bu,C, D, Lb,Lh,Lnc, Sn; Heidelberg)

When putting stockings on a child for the first time, the child will become lefthanded unless the right stocking is put on first.

106. Kinner wærre net grōs wạmmer si summers anbgewēnt. $(S c)$

If children are weaned in summer time they will die young.

107. En kind a as mer âbgewēnt, wannn di bēm blie wært glei grō. $(B e, D, S c)$

If a child is weaned when the trees are in blossom, its hair will turn gray early.

In der baumblüte ist kein kind zu entwöhnen, sonst bekommt es graue haare. $G$ 3. 767 .

108. Mer soll en kind net ạbgewēne sō lạng ạs schnē leit, schunscht wærts jung grō; å net wannns låb fun de bēm fallt, schunscht wærts jung blot ( $L b, L h, S c$, $S n$ )

A child should not be weaned as long as there is snow on the ground, else its hair will soon turn gray; nor when the leaves fall, else it will soon become bald. 
Entwöhnen darf die mutter das kind nicht, so lange schnee liegt, sonst bekommt es zeitig weisse haare; auch nicht wenn das laub von den bäumen fällt, sonst verliert es dieselben zeitig. $B S 33.116$

109. 'S ērscht wasser as mern kind drin wescht muss mer zum éberscht-schpeicher fenschter naus uf en båm schitte, nō grikts kind en hōcher gēscht. ( $D, L n c$, $M r, S n)$

A person will become highminded if the water in which it was washed immediately after its birth is thrown out of the garret window and on a tree.

Das badwasser ist unter einen grünen baum zu giessen, so bleiben die kinder stets frisch. $G 3.738$; ef. also $M D V$ 103

110. Dåfwăsser schitt mer ítbern rōse schtok, nō grikts rōte bạke. ( $B e, C, L h, L n c, S n)$

$A$ child will have red cheeks if the water used in baptism is poured over a rosebush.

Das taufwasser muss man nach der taufe in einen rosenstrauch schütten, so bekommt das kind rote wangen. $W u 391$

111. En kind muss gråd heile wanns uf di welt kummt. Wanns net dut, bletscht mers bis es dut. $(B u, C$, $L b, L h, M t, N a, S c$ )

A child should cry immediately after its birth, and it should be slapped until it does.

Das kind gilt erst dann wirklich lebendig und lebensfähig, wenn es die vier wände beschrieen hat. Daher gibt man ihm wohl gleich nach der geburt einen klaps an den hintern, damit es sich ins leben schreie. $M D V 107$

112. En kind waxt net bis es bezålt is. ( $L h, L n c, S c)$

A child will not grow until the doctor's fee is paid.

113. Der dåk ąs en kind gebōre is solle mann un frå net fill zămme schwetze. ( $M t$; Heidelberg)

Husband and wife should not talk much to each other on the day when a child is born. 
114. En kind dærf mer net ding, dingel, dingelche oder grot hēse, schunscht waxts net. $(B e, B u, C, L h$, $S c)$

If you call a child "thing" or "toad" it will not grow. Kinder darf man nicht ding, kröt oder aas nennen, sonst verkommen sie. $B S 33.115$.

115. Hēs en kind seili oder wutzli, no waxts. $(B u, D, L n c$, $M t, S n)$

Call a child "piggy" and it will grow.

116. En kind bosst mer net ufs maul bis es gezånt hot oders zånt hært. (Lb,Lh, Na,Sc, Y; Lustmann)

A child should not be kissed on its mouth before it has cut its teeth or it will teethe hard.

117. En kind årt seim peter oder gēdel nō. $(B c, C, D, L h$ $S c, S n, Y)$

A child will take after its godfather or godmother.

Der täufling nimmt geistige eigenschaften von paten an. $R$ A 210

118. 'S èrscht mōl as mern kind aus em haus nemmt, dærf mers net zu junge keierte leit nemme, schunscht grìğe si å ēns. $\quad(B e, C, D, L h, L n c, M t, N a, N u, Y)$

The first time a child is taken out of doors it must not be taken to the home of a newly wedded couple, or else they too will soon have a child of their own.

Verkehrt eine junge verheiratete frau mit anderen frauen, die in gesegneten umständen sind, so wird auch sie bald kinder bekommen. A A 35

119. Me kind sei nậelschnūr hēbt mer uf, nō wærts gscheid. (D, Lnc, Sc)

A child will become clever and bright if you preserve its umbilical cord.

Von der nabelschnur des kindes muss ein stückchen aufbewahrt werden, so hat das kind so lange glück, so lange man dasselbe sorgsam verwahrt. A $A 34$

120. En kind wū mit lange hōr uf di welt kummt wært net 
alt wạnn selli hōr net glei ausgēne. $(B e, C, L h$, $\mathrm{Mr}, \mathrm{Na}, \mathrm{Sc}, \mathrm{Y}$ )

A child born with long hair will not live long unless it soon falls out.

Kinder, welche mit langen haaren zur welt kommen, sterben früh. $W u 217$

121. Wạnn en kind mit ze $\bar{e}^{\sim}$ uf di welt kummt, lēbts net lang. (Af)

$A$ child born with teeth won't live long.

Kinder, die die zähne mit auf die welt bringen, verlieren sie und bekommen keine neue, $d . h$. sie leben nicht lange. Wu $217 ; A$ A 30

It is ill luck to be born with teeth in the head. $V S L 2.115$

122. Wann en kind im schlōf lạcht hots bauchwē. ( $B u, M t$, $S c)$

If a child smiles in its sleep, it has colic.

123. En kind as im schlof lacht wært glei gridlich waker. (Be, Bu, Lh, Lnc, Mt, Sc, Sn)

A child that smiles in its sleep will soon wake up fretful.

124. Wạnn en kind im schlöf lạcht, såkt mer di engel dēde mit im schptle. (Be, Bu,C, Lh, Lnc, Mt, Sc, Sn)

If a child smiles in its sleep the angels are playing with it. Lächelt ein kind im schlaf, pflegt man zu sagen: jetzt schertzt sein schutzengelein mit ilım. VA $S 1,492$

125. En kind gewēnt mer ąb im Fisch. (C, D, Lnc, Sc; Freiburg)

Wean a child in the sign of Pisces.

126. Mer soll en kind net im Lēb a abgewēne schunscht greischts wíscht. ( $B e, C, L h, \hat{M r}, S c$; Heidelberg) If a child is weaned in the sign of Leo it will yell like a lion.

127. En kind gewēnt mer net ạb wann di bēm blie schunscht wærts jung grōkeppich. $(S c)$

If a child is weaned while fruit trees are in blossom its hair will turn prematurely gray. Cf. 107 
128. Zærniche kinner hokt mer uf en kalter $\operatorname{schte}^{-}$. (Bu, $C, L n c, M r, M t$ )

Seat a peevish child on a cold stone.

Zornige kinder scoll man auf einen kalten stein setzen. $Z 230$

129. Wạmmerme kind sei glēder flike muss ebs en jōr ălt is, werts en schlapp. (Be, C, S, Lh, $\mathrm{Mr}, \mathrm{Me}, \mathrm{Y} ; \mathrm{Hei}$. delberg)

If a child's clothing must be mended before it is a year old it will become slovenly.

130. Wammern kind kitzelt ebs en jōr alt is waxts å . (C)

If a child is tickled before it is a year old it will be livergrown.

131. En kind as fil im gringel rum schpringt wært dumm. $(B u, C, L h, L n c, M t, N u, S c, S n)$

A child that whirls much will become stupid.

Es wird dumm und dappig (täppisch). Hlbg.

132. Der èsel hots kind aus der wand gschlağge. (Be, $B u$, $C, S c)$

The donkey kicked the child out of the wall (it is a bastard)

133. Di kinner kumme aus de hōle bēm. ( $B e, C, M r, M t$, $S c)$

Children come from hollow trees.

134. Der schtôrich bringt di kinner. $(B e, M r, S c)$

The stork brings the children.

This is common in Germany and England.

135. Der dôkter hōlt di kinner aus re grik oder aus flitsend wasser un bringt em si. $(A f)$

The physician fetches children from a creek or flowing water.

Der bach bringt die kinder. $Z f D M 2.345$

136. Mer soll en kind net lē leie losse in re schtub, schunscht schtēle di hexe es. (Lnc)

Never let a child lie alone in the room, the witches will steal it. 
Hat man das fenster offen stehen lassen, und ist niemand als das wiegekind in der stube, kommt gern eine hexe zum fenster herein und stiehlt das kind...VV A $S 1.313$

137. Wạmmern kind schpōt ōbeds aus em haus nemmt, wærts leicht ferhext. $(B e, L n c)$

If a child is taken out of doors late at night, it is easily bewitched.

Wenn man spät abends ein kind aus dem hause trägt, wird es leicht ferhext. $Z 31$

138. Me kind sei nåchgeburt em im gsicht rum geribe macht em en schēni haut. $(B e, D, Y)$

Rub the child's face with its placenta to make it fair of complexion.

Das muttermal kann die hebamme gleich bei der entbindung vertilgen; sie muss die stelle, noch ehe es sonst jemand gesehen hat, mit der nachgeburt bedrücken oder bestreichen. $K n 155$

139. Wạmmern frå im kindbett bsucht soll mer sich nimmi setze wạmmers kind mol gsēne hot kạt. $(M r)$

If you call on a woman in confinement, do not sit down after you have seen the newborn child.

140. Wạmmer ærğets hĩ gēt wū en glē bōbel is soll mer sich 's ǣrscht setze eb mers bobli å gukt, oder mer nemmt em di rū. $(B e, D, L b, L n c, N u, S c, S n, Y)$

If you make a call at a home where a child has just been born take a seat before you look at the baby or you will cast a spell over it.

Geht ein fremdes in die stube, so soll es niedersitzen, dass es den kindern die ruhe nicht mitnehme. $G 3.15$

141. En kind gebōre mit me bēl ib̄ers gsicht is gliklich. $(Y)^{\prime}$

It is an omen of good luck to be born with a caul.

Var. 1. Sōn kind wært schtolz. (Be, D, Lb, Lnc, Na, Nu, $S a, S u, Y$ )

Such a child will be proud. 
Var. 2. un kąnn dǣrich en ǣrdschpiğel sēne.

And can see through a semaphora.

Kommt das kind in der embryonenhaut auf die welt, so wird es ausserordentlich viel glück haben. $M D V 103$

I believe you were born with a caul on your head, you are such a favorite among the ladies. $V S L 2.124$

142. En nei gebōre kind muss mer wì̆ge, no waxts ērscht recht. $(B u, C, D, L b, L h, M t, S c)$

A newborn infant, to grow rapidly, must be weighed.

It is bad luck not to weigh a baby before it is dressed. $C S A 38$

143. En nei gebōre kind dærf mer net wige, schunscht waxts net. (Be,Lh, Lnc, Na, Nu, Sc, Sn, Y; Freiburg)

A newborn infant will not grow if it is weighed.

If a new born child is weighed, it will die or not thrive. Dy $9 ; C S A 39$

144. Sō as en kind gschwind schwetze lærnt soll di gōt oder der peter em kind der leffel kåfe wūs âlle dåk mit esst, di gōt fers mēdel, der peter fer der bū. (Be, Lh, Mt, Sc, Sn, Y)

A child will learn to talk more quickly if the sponsors buy for it the spoon which it uses every day in eating. The godmother should buy the spoon for a girl and the godfather for a boy.

Die paten sollen dem kind ein löffelchen kaufen, sonst lernt es geifern. $G 3.48$

Lernt das kind das sprechen lange nicht, so kauft ihm der göte einen löffel, womit man dem kinde zu essen gibt; iängt es bald zu sprechen an. A S 1.392

It was formerly the custom for the sponsors at baptism to present the children with spoons. $D$ Eng 180

145. Fill leit gebe tre kinner der nåme a a im kalenner schtēt uf der dåk wū si gebōre sin. $(B e, B u, C, D, L b$, $L h, L n c, M r, M t, N a, S c, S n)$

A child born on a saint's day, often bears the saint's name. 
En kind erhält häufig (im katholischen Deutschland) den namen des kalenderheiligen, an dessen tag es geboren ist. M D V 113

In many county parishes a child is invariably called by the name of the saint on whose day it may happen to have been born. $D E n g 178 ; C S A 5$

146. Wămmern bobbel an der bottel ufzikt soll mers nt di milich all aus der bottel drinke losse. Selli gebt mer der kântz, nō grikt di katz 's a abnemmes un nets kind. (Be,Lh,Lnc; Heidelberg)

To prevent a child from having marasmus a small quantity of milk should be left in the bottle from which it is nursed. This milk should be given to the eat, which will then have marasmus.

147. Wann en kind ferhext is nemm fum kind seim wąsser, dūs in en bottel un sex nōdle dezū', nō mach di bottel teit zu un ferschtekel si. ( $L b, L n c, Y)$

If a child is bewitched put some of its urine and six new needles into a bottle, cork it tightly and hide the bottle.

A bit of steel, such as a needle, protects one from witches. C S A 1417

Several fetid and stinking matters, such as old urine, are excellent means for keeping away all evil intentioned spirits and ghosts. $V S L$ 2.1. 460

Comment est bonne contre le rheume l'urine des petits enfans? $V S L 2.2 .489$

148. Wanndme kind ans juscht kumme is net en alti windel ã duscht, kannns ken schtūlgąng mạche. (Bu; Heidelberg)

Unless a newborn child is clothed with an old diaper it cannot stool.

149. Wămmerme kind ans juscht uf di welt kumme is net en âlti windel å dut grikts en wẽer årsch. (Bu; Heidelberg)

Put an old diaper on the newborn child to prevent sore buttocks. 


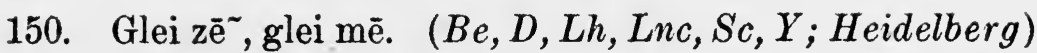
If a child cuts its teeth very early, there will soon be another child in the family.

Soon teeth, soon toes, i. e;, another baby. $\quad H N C 19$

151. En kind ạs mer in der schpiğel guke losst ebs en jōr alt wært wært schtolz. $(A f)$

A child that is permitted to look into a mirror before it is a year old will be vain.

Var. Der dritt dåk losst mers nei guke. ( $B e, D, L b, L h$, Lnc, $\mathrm{Mt}, \mathrm{Na}, \mathrm{Sn}, \mathrm{Y}$ )

Permit it to look into the mirror when three days old.

It is unlueky to allow a baby to see itself in a mirror before it is a year old. $E Y 43$

152. En frå ås en bēbi hot soll trm kind wasser ime fingerhūt hōle, no schląnterts net. ( $L b, L h, M r, Y$; Heidelberg)

A child will not drool if it is given water to drink out of a thimble.

The first time after childbirth the mother went to fetch water, she did so, not in a pail but in her thimble or in a vessel of very small content, to prevent the child's mouth from continually running saliva. GS Scot 6

153. 'S ërscht jōr schneit mer me kind di neğel net âb, mer beisst si a b, schunscht wærts en dỉb un lærnt schtēle. $(A f)$

Do not cut an infant's nails before it is a year old or it will become a thief.

Das erste jahr soll man die nägel des kindes abbeissen, nicht abschneiden, sonst kriegt es lange finger. Alem 27. $229 ; G 3.23$

Never cut an infant's nails until it is a twelvemonth old or it will be lightfingered and addieted to stealing. W Ir $68 ; C S A 55$

154. Wạmmern kind messt wạxts nimmi. (Af)

Measure a child and it will cease to grow.

Misst man die länge eines kindes, dann wächst es nicht mehr. $Z 32$ 
To measure a ehild is to measure it for its coffin. $B F^{\prime} 181$

155. Wạmmern kind engel hēst lēbts net lạng. (Lh)

Call a child "angel" and it will not live long.

156. En kind a mer mit weide wipt wært dærr $(Y)$, oder grikt di auszēring $(C)$, oder die weitschwelling. (Lnc, $S c, S n$ )

A child whipped with willows will emaciate or develop tuberculosis or synovitis.

Man darf das kind nicht mit einer weidenrute strafen sonst bekommt es abzehrung. $W u 393 ; G 3.416$

157. En kind as uf di welt kummt nochdem as sei fader gschtærte is kann fær ēnich ebbes brauche $(B u)$, fer blōhūschte $(B e, Y)$, færs bēsding.' $(B e, D, L b$, $L h, L n c, S n, Y)$

A posthumous child can cure whooping cough, felons or anything else by powwowing.

Nach des vaters tod geborene kinder haben die kraft, felle, die auf den augen wachsen, drei Freitage hinter einander abzublasen. G 3.1009

A posthumous child was said to possess the gift of euring almost any disease simply by looking at the patient. G Scot 37

158. Wạnn en kind kântzehōr ins maul grikt schtærbts ån der aus'zēring. ( $L b, L h, L n c, M t, Y)$

If a child swallows a cat's hair it will die of tubereulosis.

Wenn jemand ein katzenhaar schluckt, bekommt er die ab. zehrung. $Z 800$

You will die if you get a cat's hair into your stomach. $V S L 2.1401$

159. En grexich kind lēkt mer in en sei nescht bis es wårm is, nō fergēt em sei ${ }^{\sim}$ grexe. $(B e, C, D, L b, L h, M r$, $\mathrm{Na}, \mathrm{Nu}, \mathrm{Sc}, \mathrm{Sn}, \mathrm{Y}$; Heidelberg)

Lay a grunting child into a pig's lair to cure it of its grunting.

160. 'S kind wū dem nō kummt âs uf der ērscht dåk fume zēche gebōre is is wider en bũ (bezw. en mēdel). 
Wannn sich der zēche ånber der nēkscht dåk wexelt is 's nēchscht wū kummt net fun der sēme sært. $(D, L h)$

If a child is born on the first day of a zodiacal sign, the next child to be born will be of the same sex. If however the sign of the zodiac changes, the sex of the child following will also change.

Wenn ein frau an einem tage gebiert, auf welchem im Kalender noch mehrere tage mit demselben himmelszeichen des tierkreises folgen, so folgen noch ebensoviel kinder desselben geschlechts. $B S 33.114$.

When a birth takes place on the growing of the moon, the next child will be of the same sex, but if on the waning moon the sex will change. Corn 157

161. 'S dreizēnt kind gebt en schpilmannn. (Mt)

The thirteenth child will be a musician, i. e. no good.

162. Der sibet $\mathrm{su}^{\sim}$ gebt en grosser mannn. (D,Lnc, $\left.Y\right)$

The seventh son will be a famous man.

Der siebente wird schön und gescheid. Hlbg

163. Der sibet sū $\sim$ gebt en pærre odern dokter. $(\mathrm{Be}, \mathrm{D}, \mathrm{Na})$

The seventh son will be a clergyman or a physician.

Der siebente sohn ist glückselig etwas zu heilen, pflanzen oder sonst auszurichten. G 3.180

The seventh son will cure diseases. $H 45$

164. Wannn en mannn sex kinner hot fun ēnre sært is 's sibet schūr fun der anre. (Lh, Mr; Heidelberg)

There are never seven children of the same sex in succession in a family.

165. Mer schtekt en kind as juscht uf di welt kumme is gråd in kąlt wasser, nō wærts hært. $(B e, D, M t$, $S n, Y)$

Dip the newborn child into cold water immediately after birth to harden it.

166. Gscheite kinner wærre net alt. (Af)

Precocious children will not live long.

Gescheite kinder werden nicht alt. $Z \mathbf{Z} 43$ 
Children prematurely wise are said not to be long-lived. D Eng 176

167. Wạnn en kind schtærbt as noch an drinke wår soll mer sei hemm der mutter an di bruscht lēğe, nō grikt si ken drubel mit der milich. (Lh; Heidelberg)

If a child dies before it is weaned lay its chemise on its mother's breasts to prevent them from becoming sore.

168. Wạnn en kind aérik heilt hot di mutter hunger kạt fær ebbes as si net grikt hot. ( $C$; Heidelberg)

If a child cries constantly its mother was hungry during pregnancy for something which she never got.

169. Wann en kind mit ze $\overline{\mathrm{e}}^{-}$uf di welt kummt is es en schlechti sein. (Be, Bu, D, Lnc, Mt,Sn, Y; Heidelberg)

It is a bad sign to have a child born with teeth.

170. 'S sîbet kind gebt en grōsser mann. (D, Lnc, $Y$; Heidelberg)

The seventh child will be a prominent man.

171. Wammern jung kind dråkt un hot selbert kens ærbts. (Bu, Lb, Lnc, Mt, Sn; Heidelberg)

If you carry a young child and have none of your own you will soon have one too. 


\section{FUTURE HUSBAND}

172. Wạnd kaffi ausschittscht, wannd bsuch grikscht, kannnscht 's pikter fume mannn oder frå sēne. ( $\mathrm{Na}$; Heidelberg)

When you pour the coffee from the cup you can see from the picture in the cup whether your visitor will be a man or a woman.

173. Wamme weibsmensch der frak hinne nufgedrēt is låft re en widmann nō. $\quad(D, L b, L h, L n c, N a, N u)$

A woman whose skirt turns up in the back has a widower as a suitor.

Schlägt sich der saum des kleides um, so wird man von einem witwer geliebt. $A \boldsymbol{A} 20$

174. Wạmme weibsmensch der frak hinne nufgedrēt is, hot si en bō $(B e, C, D, L h, M r, M t)$; oder si wæert disąppoint seller dåk $(S n)$; oder si grikt seller dåk noch geld, a âter si muss uf der frak schpane. $(S n)$

If a woman's dress turns up in the back she has a lover; or it is an omen of disappointment that day ; or she will receive some money, but she must spit on her dress.

175. Wạn en weibsmensch en dærn oder hek nōschlēft låft re en bō nō. (Be, Bu, C, D, Lb, Lh, Mt, Na, Nu,Sc, $Y)$

A bramble in a woman's skirt indicates a lover.

Hängt sich ein dornenzweig an dich, so will dich ein witwer zur frau haben. A A 20

176. Schpell en fîr blettrich glēblåt oøich di dîr un der èrscht mannskærl ạs zū der dỉr nei ${ }^{\sim}$ kummt gebt dei mann. $(A f)$

Pin a four-leafed clover over the door and the first man to enter by that door will become your husband.

Vierblättrigen klee soll man unter die sohlen legen, um eine person $\mathrm{zu}$ gewinnen. $L V 152$ 
177. Henk en hinkelgnoche otich di dìr un der ērscht manskærl as rei ${ }^{\sim}$ kummt gebt dei ${ }^{\sim}$ mann. $(S n)$ Hang a wishbone above your door and the first man to enter will become your husband.

178. Mer soll en fïrblettrich glēblåt schluke un an an sei ${ }^{\sim}$ bō denke, nō grikt mern. ( $\mathrm{Be}, \mathrm{Lh}, \mathrm{Na}, \mathrm{Y})$

You will marry the man whom you think of while swallowing a four-leafed clover.

Wer vierblätterigen klee findet, soll ihn wert halten; sulang er ihn hat, wird er glückselig sein. $G 3.119$

A four leaved clover is a beneficent attractor of the opposite sex. $H 25$

179. Rūf di Sēnt Ągnes å uf der Sēnt Acgnes dåk (21. Jenner) si sott dich dei mann sēne losse, un såk: "St. Acgnes, sei en freind zu mir, loss mich di nạcht mei man (oder frå) sēne. ( $L h)$

On St. Agnes' day eall upon St. $\Lambda$ gnes beseeching her to show you your future spouse, saying: "St. Agnes be a friend of mine. Permit me this night to see my future spouse."

Am Andreasabend, vor dem schlafengehen, am besten in der mitternach, spricht das heiratslustige mädehen: " $O$ heiliger Andreas, ich bitte dich, du mögest lassen erscheinen den herzallerliebsten meinen, wie er geht und wie er steht, wie er mit mir zur kirche geht, im namen usw. $W u 249$

Sweet St. Agnes work thy fast,

If ever I be to marry man,

Or man be to marry me,

I hope him this night to see. $H N C 91$

180. Di mēd in re fạmilie gríğe ken menner wănmer pōhåne fedre im haus hot. ( $L h, L n c, Y)$

Your danghters will not marry if there are any peacock's feathers in your house.

Pfauenfedern bedeuten ïberhaupt unglück. Hlbg.

If peacock feathers are kept in a house for ornament, the 
young ladies in the house need never expect to be married. $C F Y 2.76$

181. Wămmer pōhåne fedre im haus hot griğe di mēd in der familie menner. $(B u, M t)$

Your daughters will get married if you have peacock's feathers in the house.

182. Ōbeds fer neijōr soll en mēdl di schtub auskēre, nō kạnn si ìr mạn im schpiğl sēne. (Be,Lnc, Nu,Sn) Sweep your room (or parlor?) backwards, on New Year's eve, and you will see your future husband in the mirror. In der Neujahrsnaeht kann ein mädchen ihren zukünftigen auf diese weise erkennen: sie kehre nachts um $12 \mathrm{uhr}$ nackt und rüeklings die stube aus, dann erseheint im spiegel oder fenster das bild des bräutigams. $V A S$ 1. 469.

183. Wạmmer nein ōted nein schtærne zēlt, der ērscht ąs mer hạnds schēkt mit, hot der nåme fum mannn ans mer grikt. $(N u)$

Count nine stars on nine successive nights, and the first man with whom you shake hands bears the name of your future husband.

Count nine stars on nine nights in suceession, and the first young gentleman with whom you shake hands is to be your future husband. $C S A 270$

184. Wạmmer fî̀ zwił̌le nåmt un lēkt si ōbeds unners bett oder unich der ofe, selli wū mærğets ausgewaxe is hot der nåme fum mann as mer grikt. $(B e, L h$, $M r, S n)$

Take four onions, name them and place them under the bed or the stove in the evening. The one which has sprouted next morning bears the name of your future husband.

Die Gasteiner dirnen nehmen vier zwiebeln, stellen sie in die vier winkel der stube und geben ihnen namen von junggesellen; die zwiebeln lassen sie stehen von Weih. nachten bis auf Dreikönigstag. Wessen zwiebel nun keint, der wird sich als freier melden. G 3.956 
185. Wạmmer middåks zwischich elf un zwelfe esst dǣr was kummt gebt em sei mann. $(B e, L h)$

The man who comes to your house between eleven and twelve while you are at dinner will be your future hus. band.

......aber nur am Neujahrstag. Hlbg.

186. Wạnn di måd di drebbe nuf fạllt, grikt si en neier bō. $(Y)$

If a servant girl falls upstairs she will have a new beau.

187. Wạnn di måd di drebbe nuf fạllt grikt si sibe jōr ken mann. $(Y$; Heidelberg $)$

If the servant girl falls up stairs she will not marry for seven years.

188. Wạnn di måd di drebbe nuf fạllt, sō fill drebbe ạs noch fær re sin, sō fìl jōr muss si wårte, bis si en mann grikt. (Be, Lb, Lh, Mr, Mt, Na,Sn, Y)

If a servant girl falls up stairs, the number of steps to the top of the stairs indicates the number of years which will elapse before she marries.

189. Wạmmer neie schū grikt, soll mer si å̃ losse fer ins bett. Nachts kummt ēner fer em si ausdū . Seller gebt em sei mann. (Lh)

When going to bed, keep on the new shoes which you have just bought, and the man who comes to take them off will be your future husband.

190. Wǣrs ērscht zu re dîr nei kummt wū en bruschtknoche fume hinkel ōtich der dîr henkt gebt sellem mēdl wū en hĩ ₹enkt hot sei mannn. (Be,Bu,C,Lh, Lnc, $M r, M t, S u, Y$ )

The first man to enter a room by a door over which a wishbone is placed, will become the husband of the girl who put it there.

Put the breastbone of a fowl over the front door and the first one of the opposite sex that enters is to be your future companion. $C S A 220$ 
191. An re hochzich soll mer sich kuche mit hēm nemme un ōbeds eb mer ins bett gēt en schtik defuñ $\tilde{n}^{\prime}$ unichs koppekissi lēğe. Des wạs mer nạchts dråmt defun wært em sei mann (oder frå). ( $A f)$

Take home with you a piece of wedding eake. Before retiring put it under your pillow and the person you dream of will become your future spouse.

Am Andreastage nehmen oft die mädchen ihre kleider unter das kopfkissen um von ihrem zukünftigen mann zu träumen. Alem. 25, 52

Place tiny scraps of bridecake under the pillow at night to dream of "him". $\quad$ H 9

192. Wạnn en mēdel bosscht wannn en dạtteldautehærz in maul hoscht muss sell mëdel dich gleiche. $(D, Y)$ Kissing a girl, with the heart of a turtledove in your mouth, acts as a love charm.

Dass dich eine lieben muss, nimm eine turteltaubenzung ins maul, rede mit ihr lieblich, küsse sie darnach auf den mund, so hat sie dich so lieb, dass sie dich nicht mehr lassen kann, oder sie kann dir nichts versagen. $A M 2,9$

193. En mëdl dærf net ạn bűe denke eb si en mannnshemm mạche kạnn un en boî'dēk rund ausrolle. (Be, Lnc; Freiburg)

A girl must not think of marrying until she can make a man's shirt or roll a round pie crust.

194. Dǣr wū mer drå denkt wạmmern hinkelhærzel rō schlukt gebt em sei mann. (C,Lb,Lh,Lnc, $M r$, $\mathrm{Na}, \mathrm{Nu}, \mathrm{Sn})$

Swallow a raw chicken heart and the one you are thinking of while doing it will be your future husband.

195. Dråk en eilehærzel im såk nō wannnde fil å gsēne sei ${ }^{\sim}$ witt bei de mēd. ( $D, L b, M r, N a, Y)$

If you would have the admiration of the opposite sex, carry the heart of an owl on your person.

196. Ēner âs fíl å gsēne sei ${ }^{\sim}$ will bei de mēd muss finffingergraut im sạk nōdråge. $(B e, L h, M r, Y)$ 
To gain the admiration of girls carry cinquefoil (potentilla canadensis) in your pocket.

Die wurzel des fünffingerkrants Johannis vor sonnenaufgang gegraben hilft zu mancherlei und erwirbt dem, der sie bei sich trägt, die zuneigung andrer. $G 3.850$

197. En droppe blūt aus em linke glēne finger me mēdl ins wassser gedū macht sell mēdl em mann wūs dut nōlåfe. $($ Lnc)

A drop of blood taken from the little finger of a man's left hand and put into the water which a girl is about to drink, will cause her to fall in love with him.

Wollte man jemanden sich geneigt machen, so musste man einen tropfen schweiss von sich ins essen or in den trunk fallen lassen, den die geliebte person $\mathrm{zu}$ sich nahm, und sie war gezwungen zu lieben. $Z$ f $D M 1.242$

198. Wạnn en weibsmensch sich ferschlappt iterm wesche grikt si en sifer. $(B e, L h, L n c, N u)$

If a woman wet her apron in washing her husband will be a drunkard.

Weibsbilder oder frauennamen, so beim waschen nasse schürze bekommen, kriegen einen trinker zum mann. A S 1. 415

If a maid gets her clothes very wet when she is washing, she will have a drunken husband. $C F L \& R 1.66 ; C S$ A 368

199. Wannd zum mēdl witt un si will dich net, nemm zuker, dū den uñich der årm bis er wårm is un îre nō ins drinke, nō losst si dich. $(N a, Y)$

Sugar which is held in the armpit until warm acts as an aphrodisiac if put into the drink of a girl who spurns your advances.

Man trägt obst, besonders einen apfel, oder weissbrot, oder ein stück zucker so lange auf der blossen haut unter dem arme bis er vom schweiss durchdrungen ist und gibt es dem anderen (d. h. dem mädchen) zu essen. $W u 366$ 
200. Schēl en abbel sō ạs di schål gạnz bleibt un schmeis selli schål nō iøer di links schulter. Der buschtậte wūs macht fạngt em seim bō seĩ nåme å . $(B u, D$, $L b, L h, L n c, N a, N u$ )

Pare an apple and then throw the whole paring on the floor over your left shoulder. The letter formed will be the initial of your beau's name.

Wenn man einen apfel vom butzen zum stiel schält, und zwar alles an einem stück, diese schale sodann rückwärts über sich wirft, dann kommt der anfangsbuchstabe des künftigen mannes zum vorschein. $V A S 1.478$

October 28 th.... is the most propitious day for the discovery of the future one's initials. Take a fine round apple, peel it in one whole length. Take the paring. . in the right hand..drop it over the left shoulder and it will form the initial of your future husband's name; if it breaks in pieces, you will die an old maid. $H 70$

201. Mer soll en schlissel in di bỉbel lēğe ạn der schtell Hohelied 8. 7. Wạmmer an der buschdåte kummt wū em seim bō sei ${ }^{2}$ nåme å fangt mit, drēt sich der schlissel in der bïbel. $(B e, B u)$

Take a key and place it in a bible on the seventh verse of the eighth chapter of the Song of Solomon. When you reach the initial letter of your sweetheart's name the key will turn in the bible.

Die schlüsselprobe geschieht folgendermassen : in ein gesangbuch wird ein schlüssel gesteckt, um das buch ein band gebunden, dann der ring des eingesteckten schlüssels auf die finger gesetzt, so dass er darauf umläuft, und nun geschehen fragen. $G$ 3. 932 .

Divinations also by Bible and key. cf. $H N C$ 235-7

If two persons wish to marry, they must take the churchkey and place it over Song of Solomon 8, 6-7. C F Suf 1.95

202. Mer muss blei schmelze un nō dærich en loch ime schlissel in en glås wassser dũ un wasseђ'er di mottle sin, sell handwærk hot der mann as mer grikt. $(B e, D, L b, L h, N a, S c, Y$ ) 
Pour molten lead into a glass of water through the hole of a key. The figures thus formed represent the occupation of your future husband.

Giesst eine ledige in der Christnacht heiss blei in kaltes wasser, so bildet sich das handwerksgerät ihres künftigen bräutigams. $G 3.97 ; G 3.579 ; B S 33 \mathrm{p} 124 ; 6$. und 7 . Buch Moses p. $400 ; C S A 288 ; H 5$

203. Koch en oi hært, schneits in der mitt dærich un fill $\overline{\mathrm{e}}^{\sim}$ helft mit săls. Ess selli une wassser gedrunke un $\mathrm{ge}^{-} \sim$ nō hinnerschich di schtēk nuf fer ins bett. Der mannskærl as dir nacchts wassser bringt gebt dei mann. $(B e, L h)$

Boil an egg hard, cut it in halves and fill one of them with salt. Eat this without drinking water, going backward up the stairs to bed. The man who will bring you water during the night will become your husband.

Boil an egg hard, take out the yolk, and fill its place with salt. Eat it before going to bed. The one you dream of as bringing you water is your future husband. To be done by two girls in silence, going backward as they retire. $C S A 228 ; D y 33$

If the dumbeake be eaten, strict silence must be observed from the moment the slice is cut. The person walks backward from the room, up the stairs, and after undressing goes to bed, still backwards. It is presumed that happy dreams of "the loved one" will occupy the hours of slumber. $H 12$

204. Wănns gschærrwąsser kocht grikt mer siちe jōr ken mann. ( $A f ;$ Neustadt)

A boiling tea kettle is a sign of not getting married for seven years. 


\section{MARRIAGE}

205. Es heiere fîl Dunnerschdåkmærğets frì. $(D, N u, S n)$ There are many weddings early on Thursday mornings.

206. Dinschdåk un Dunnerschdåk sin di hoch'zichdåk. (Be, $\mathrm{Bu}, \mathrm{Lnc}, \mathrm{Mr}, \mathrm{Mt}, \mathrm{Na}, \mathrm{Nu}, \mathrm{Sc}, \mathrm{Sn}, \mathrm{Y}$ )

Tuesday and Thursday are favorite wedding days.

Zum heiraten ist der Dienstag gut. A S 1.390; Donnerstags heirat, glückheirat. $W u 60$.

207. Es gebt å dēl hochziche Sunndåks.

There are some weddings on Sunday.

Sunday is an exceptionally fortunate day upon which to enter the holy state. $H 22$

208. Sạmschdåks is der hochzichdåk unich de steilische leit un de niğer. $(L n c)$

Saturday is the wedding day among society folk and negroes.

Hochzeiten werden gewöhnlich am Samstag gehalten. $Z 116$

209. Es heiern å fil Mittwochs. (D)

Many weddings are held on Wednesday.

210. Sạmschdåk un Sunndåk sin di beschte hochzich dåk. ( $\mathrm{Be}, \mathrm{C}, \mathrm{Lb} . \mathrm{Lh}, \mathrm{Lnc}, \mathrm{Mr}, \mathrm{Na}, \mathrm{Sc}$ )

Saturday and Sunday are the best wedding days.

Sunday is an exceptionally fortunate day on which to enter the holy state. $H 22$

211. Mer soll heire wann di zoier fun re ūr eber'schich gēne, also noch de sex ūr. $(D, L n c, M r, M t, Y)$

Marry when the hands of the clock are moving upward, that is, after six o'clock.

Das ehepaar bekommt viele kinder, wenn es sich zwischen 11und $12 \mathrm{uhr}$, also den höchsten stundenzahlen trauen lässt. $B M 20$ 
212. Mer soll in ebbes gilēntes heiere fer glik. $(B e, D$, Lnc, $M t, N a, S n, Y$; Freiburg)

Marry in something borrowed.

213. Wạnn zwē in ēnre fạmilie heire ime jōr hen si ken glik. (Af; Heidelberg)

Two weddings in one family and within a year are unlucky.

214. Wann zwē pår minanner heire heiert 's ent em annnere

's glik wek. (Af; Heidelberg)

If two couples are married at the same time by the same clergyman, one of them will be unhappy.

215. Wạmmern schwærzi katz $\mathrm{a}^{\sim \prime d}$ drefft uf em wēk zum pærre fer heire bedeits as mer schlecht glik hot. (Be, C, Lh, Lnc, $M r, N a, S c, Y$; Heidelberg)

It is a bad omen to meet a black eat when on one's way to the clergyman to get married.

To meet a priest, hare, eat, dog, lizard or serpent on going to church to get married was considered unlucky. $C P \& P 489$

216. Wann en weibsmensch heire will soll si di katz aus îrm schū fìdre fer glik. ( $L h, S n)$

When a girl is anxions to marry, she should feed the cat from her shoe.

Wenn mädchen heiraten wollen, sollen sie der katze schmeicheln und sie gut füttern. $Z 88$

217. Des wạs sei hochzich glēder 's letscht auswērt is der bås. $(L n c)$

Of a married couple the one who wears out the wedding clothes last will be boss in the family.

218. Der ērscht mærğe ạs en pår keiert hen dærf der mann seinre frå di hose net å bite schunscht muss er sich sei lebdåk fun îre båse losse.

If a man offer his trousers to his wife the first morning of wedded life he will be henpecked.

... dann hat die frau die hosen und zum mann sagt man, du steckst unter dem pantoffel. Hlbg. 
219. En mēdl as fil lacht uf der dåk ans si heiert muss in fre lēbenszeit fill heile. ( $A f)$

A laughing bride becomes a weeping wife.

Eine lachende braut wird eine weinende braut. $Z 128$

220. Wł der dåk ås mer heiert, sō di fąmilie. Wănns reğert hot mern schtrublichi fanilie (di frå muss fill heile); wanns schtærmt, fechte di leit fìl $(A f)$; is der dei'henker lōs. $(S c)$

As the weather on the weddingday, so the married life. Rain foreshadows trouble and sorrow; storm: quarrel or the devil is to pay.

Grosser sturm am hochzeitstage oder bei der brautwäsche bedeutet eine stürmische ehe. $B S 33$ p 118

221. Wammer heiert ime schnēschtærm wært mer reich. $(L h)$

Marry in a snowstorm and you will become rich.

Am hochzeitstage bedeutet schnee eine glückliche ehe. $G$ 3. 1051

222. Wanns me pår uf die réder schnēt uf der hochzichdåk bleibe si net lang beinanner. $(M t)$

If it snows on the carriage containing the bridal couple, they will soon separate.

223. Di glēder ăs mer å hot ån seinre hochzich dærf mer net ausdū $\sim$ fer nacht, schunscht hot mer ken glik. (Lh; Heidelberg)

Changing one's wedding clothes before night brings bad luck.

224. Wănns reğert wạnn en pår heiert gebts rotziche kinner. $(\mathrm{C}, \mathrm{Na}$; Heidelberg $)$

If it rains while a couple is being married, they will have snivelling children.

225. Wanns schtærmich is der dåk fær der hochzich bedeits drubel fær di frå; uf der hochzichdåk fær der mann. (Be, D, $Y$; Freiburg)

Stormy weather on the day before the wedding forebodes trouble for the bride; on the wedding day, for the groom. 
226. Drei dåk fær re Amische hochzich muss der mann ąs heire will seinre zükinftiche frå helfe 's săch fer di hochzich zurécht grìge. $(L n c)$

Three days before an Amish wedding the groom-to-be goes to the home of his prospective bride to aid in preparing for the wedding.

Die brautleute dürfen an den letzten drei nächten vor der trauung nicht unter einem dache schlafen. $Z 111$

227. Wạmmer di hochzichglēder gråd auswērt wært mer reich. (Nu; Freiburg)

Wear out your wedding garments quickly and you will be wealthy.

228. Leit as zu nix emaunte gríğe di deitsch bąnd in unner Măngạmri, in ober Mangañmri grikt si schir ēnich ebber. Wạnn si si net grìge mēne si in Bæriks, oter Boks un im unnre end fun Lechå si dēte net gūt schtẽ . $(B e, B u, L h, M t, N a)$

In lower Montgomery the ne'er-do-well have a calathumpian serenade; in upper Montgomery almost every newly wedded couple is serenaded; in Berks, upper Bueks and the lower end of Lehigh the lack of a serenade is interpreted as a lack of regard.

229. Di hochzichglëder dærf mer sich net selbert mache, schunscht hot mer ken glik. ( $B e, L h, L n c, N a, S n$, $Y$ )

You will have no luck if you make your own trousseau.

Das brautkleid darf sich ciie braut nie selbst nähen, da sie sonst in der ehe sorge und kummer hat, so dass sie es nicht ertragen kann. A $A 22$

230. Fume neie keierte pår, des wūs ērscht ins bett gēt schtærbt s ērscht. (C,Lb, Lnc, $Y$; Lustnau)

The first to go to bed on the wedding night will be the first to die.

231. Wạnn en pår a jus juscht keiert hen ins bett gēn, des wŭs ērscht ei ${ }^{\sim}$ schloft gēts ērscht dōd. $(N u)$ 
When a couple has just been married, the first to fall asleep will be the first to die.

Wer von den brautleuten zuerst einschläft, stirbt zuerst. G 3. 717

The first to go to sleep on the wedding night will be the first to die. $V S L 2.94$

232. Sō fîl feğel ăs mer sēnt uf sei ${ }^{\sim}$ hochzichdåk, sō fîl kinner grikt mer. $(D, Y)$

The number of birds seen on your wedding day indicates the number of your children.

To see a flight of birds as a couple go to church to be married foretells many children. $V S L 2.66$

233. Wạn en mēdel in schwærze glēder heiert muss si fìl drauerglēder wēre. (Be, Bu,C,Lh, Mr, Mr, Na $N u, S n, Y$ ) oder hot unglik. (Be,Lh,Lns, Sn)

If a girl wears a black wedding dress, she will wear a mourner's weeds or will have bad luck.

Wenn eine braut am hochzeitstage ein schwarzes kleid trägt, bedeutet es unglück. $Z 119$

It is unlucky to wear a black dress at a wedding. $V S L$ 2. $1.277 ; C S A 336$

234. En hochzich dærf mer net ufschitbe oder mer hot ken glik. (Af; Heidelberg)

Postponing a wedding day brings bad luck.

It is bad luck to alter the day fixed for a wedding or a christening. VSL 2. 1. 233

235. Wạnn en jingers ausre familie heiert misse di eldre lettiche schweschtre in seidne schtrimp danze. ( $L h$, $\mathrm{Na}$ )

If a younger sister marries before her older sisters, the older ones must dance in silk stockings.

Green stockings were sent to any elder sister in Scotland if a younger sister was married before her, that she might wear them as a forsaken maiden at the dance which followed the wedding. $B F 114$ 
236. Wạnn en jingers heiert, misse di eldre lettiche gschwischdre ime seidrōk danze, $(B e, B u, D, L b$, $M t, N a, N u, S c$ ) oder der bakkōfe reite. (Af)

If the youngest member of a family gets married the older single members must dance in a pig's trough, or they must ride on the bakeoven.

Another curious custom which was once practiced in different parts of the country was that of the elder sister dancing in a hog's trough in consequence of her younger sister marrying before her.... It was considered most correct to dance in green stockings. Dy 43;CSA 361

237. En mēdel muss fil heile wanns reğert uf der dåk wūs heiert. (Be, C, D, Lb, Lh, Lnc, $\mathrm{Mr}, \mathrm{Na}, \mathrm{Nu}, \mathrm{Sc}$, $S n, Y)$

A rainy wedding day forebodes a tearful married life.

Wenn's am hochzeitstage regnet oder schneit,

Hat das brautpaar streit. $Z 141$

If it rains while the wedding party are on the journey to or from church, then a life of unhappiness is to be expected. D Eng 199

238. En mēdl as net heilt wanns heiert muss fill heile nōch'hæ̈r. (Lnc)

A laughing bride makes a weeping wife.

Wenn die braut nicht bei der traung weint, muss sie in der ehe viel weinen. $Z 143$

The bride should weep on her wedding day. $D y 40$

239. Im Moi gebts ganz we'nich hoch'ziche. (Be, $B u, L b$, Lh, Lnc, Mt, Na, Sc, Y)

There are very few weddings in May.

Im Mai werden keine hochzeiten gehalten, weil es der eselmonat ist. $Z 116$

Marry in May and you'll rue the day. $D y 37$

240. Wạnn en witfrå heiert soll si uf îr hochzichdåk en pår hose flike. (Lnc) 
A widow should mend a pair of trousers on the day that she marries again.

Wenn eine witwe heiratet, soll sie am hochzeittage eine hose flicken. $Z 145$

241. Wanmer gēle blume an sich hot uf der hochzichdåk hot mer ken glik. (Lnc, Na)

Yellow flowers are unlucky on one's wedding day.

Gelbe blumen bei hochzeiten bedeuten unglück. $Z 117$

242. Wăn en mann heiert muss er uf seim hochzichdåk en hemm å hấte as sei mēdl ìm gschenkt hot. (Lnc) A man should wear on his wedding day a shirt which his bride gave him.

Der bräutigam muss am hochzeitstage ein hemd tragen, das ihm die braut geschenkt hat. $Z 137$

243. So lạng ås di hochzichglēder net ausgewōre sin hot mer ken glik. ( $C, L b, L n c, N a, S n, Y$; Neustadt $)$

You will not be lucky until your wedding garments are worn out.

244. Mer wært net reich bis mer sei ${ }^{\sim}$ hochzichglēder ausgewōre hot. $(\mathrm{Mt}, \mathrm{Na})$

You will not be rich until your wedding clothes are worn out.

245. Wạmmer heiert muss mer it̄ern bēsem schttl tschumpe fer glik. (Af)

To have luck in married life, jump over a broomstick after the wedding.

246. Wann en pår a jas juscht keiert hen hēm kumme misse si íbern bēsem schritte, nō wærre si net ferhext. (Be, Bu, C, Lb, Lnc, Mr, Na, Nu,Sc, Y)

To prevent being bewitched a newly married couple should step over a broom on entering their house.

Wenn ein ehepaar das haus zum erstenmal betritt, muss es über einen besen schreiten; dann wird es nicht verhext. Z 135 
247. Wann en nei keiert pår 's êrschtmol in îr haus kumme misse si iøern bēsem schritte, nō wærre si net ferhext. ( $B e, B u, L b, L h, M r, M t, N a, N u, S c, S n, Y$ ) When a newly wedded couple enter their own home for the first time they must step over a broom to prevent their being bewitched.

Wenn ein neues ehepaar das haus zum ersten mal betritt, muss es \&ber einen besen schreiten; dann wird es nicht verhext. $Z 135$

248. 'S is schlecht glik fer mē ạs êns ausre fạmilie zu heire in ēm jōr. ( $L h)$

It is bad luck for more than one of a family to get married within a year. 


\section{DREAMS}

249. Wạmer færm mærğeesse ferzēlt was mer di nacht defōr' gedråmt hot wærts wōr. ( Na; Freiburg)

Relate the dream before breakfast and it will come true. $C S A 589$

250. Wạmmer dråmt di geil gengde em daérich gebts reğe. $(\mathrm{Na})$

Dreaming of a runaway is a sign of rain.

Es geht einem etwas durch. Hlbg.

251. Wạmmer dråmt mer dēt nunnerfălle dèt mer in sinde fạlle. $(B e, L n c, S c)$

If you dream of falling you will commit sin.

Dann gibts unglück. Hlbg.

252. Wạmmer dråmt funre leicht gebts en hochzich. ( $C$, $\hat{D}$, Lnc, $M t, N a, N u, S c, Y$; Heidelberg)

To dream of a funeral means a wedding. C S A 568

253. Wạmmer dråmt fun kạtze bringt ebber en æriğer liğeschtreit uf wēğich em ebæ'rtich wannn si em beisse. $(B e, C, L n c, Y)$

If you dream of cats and especially if you are bitten by them you will be the subject of a scandal.

Dann gibt's streit. Hlbg.

254. Wạmmer fun milich dråmt fallt mer aérik in lìb mit ebber. $(L h, M r)$

Dream of milk and you will fall violently in love.

Wenn ein mädchen oft von milch träumt, kommt sie zu fall. $W u 228$

255. Wåmmer dråmt fun schnē gebts ebbes ạs em net bassst. (C, Lb, Lh, Mr, Na; Freiburg)

Something inopportune will happen if you dream of snow. 
256. Wạmmer fun oier dråmt, gebts schtreit. (Af)

Dreaming of eggs indicates a quarrel.

Wenn einem von eiern träumt, so bedeutet es streit und feindschaft. Alem 19.166; $Z 262$

To dream of eggs indicates that something is coming to cause much annoyance. $G S \operatorname{Scot} 29$

257. Wạmmer fun drékich wasser dråmt bedeits drubel odern leicht. (Be, D, Lb, Mr, Mt, Na, Nu, Sc, Sn, Y) Dreaming of muddy water means trouble or a death.

Wenn einem von trübem wasser träumt, so hat man bald verdruss. $D$ M 2.292

If you dream of dirty water, bad news is at hand. $H 31$

258. Wạmmer dråmt fun grōss un drìb wassser schtærbt ens. $(A f)$

Dreaming of high and muddy water is a sign of a death.

259. Wammer fun hell waser dråmt bedeits glik $(C, D$, $L b, M r, M t, N a, S c, S n, Y)$ oder gūte neiichkēte (Lnc, Y) oder mer grikt gelt gschenkt inseit me mūnet. $(L n c)$

Dreaming of clear water brings good luck or good news or a present of money within a month.

Wenn man von wasser träumt, ist es ein schlechtes zeichen. $Z$ 263-266

Dreaming of water, if it be clear, will bring you good news. H 31

260. Wạmmer dråmt fun wạsser bedeits drubel odern leicht. (Af)

Dreaming of water means trouble or a funeral.

Wenn jemand von wasser oder wäsche träumt, stirbt jemand aus der verwandschaft. $D M 2.421 .61$

To dream of water means coming disease. $G$ Scot 29

261. Wạmmer dråmt fun hōch wasser bedeits en dōd. ( $Y$; Freiburg)

Dreaming of high water is an omen of death.

262. Fume dōde dråme bedeit glik. (Be, Lb, Lnc; Heidelberg)

It is a good omen to dream of the dead. 
263. Wămmer dråmt funre leicht gebts reğe $(A f)$ oder hōch wassser. $(S c)$

Dreaming of a funeral is a sign of rain or high water.

To dream of the dead is a sign of rain. $C S A 501$

264. Es gebt hochzich wạmmer dråmt fume dōde.

Dreaming of the dead means a wedding.

Ein traum von sterben bedeutet eine hochzeit in der verwandtschaft, und umgekehrt. $L V 94$

265. Wămmern pǣrti macht fer ebber, was mer selli nacht dråmt wært wōr. (Bu; Freiburg)

If you give a party for some one, what you dream the night before the party will come true.

Dreaming about balls, dances etc., indicates good fortune.

D $Y 177$

266. Wă mer dråmt åme blạtz wū mers ērschtmol schlōft wært wōr. $(A f)$

What you dream the first night you are in a strange house will come true. $C S A 581$

Wenn jemand zum erstenmal in ein haus kommt und darin schläft, was ihm die erste nacht träumt, das wird wahr. G $R 188$

267. Zēl di bă ğge im haus wūds ērschtmol schlōfscht un was de selli nacht dråmscht wart wōr. $(C, D$, Sc, $Y$ )

Count the crossbeams in the house in which you are sleeping for the first time and your dreams will come true.

268. Wammer ime neie oder fremme haus schloft soll mer di dreppe zēle iøerm schtēknufgē ${ }^{-}$. Was mer selli nạcht dråmt wært wōr. ( $A f)$

Wer zum erstenmal in ein neues haus oder gemach kommt und darin schläft, was ihm die erste nacht träumt, wird wahr. G 3. 123

269. Wạmmer dråmt mer hett en zå ferlőre schtærbt ēns aus der familie. ( $\mathrm{Be}, \mathrm{Lb}, \mathrm{Lh}, \mathrm{Na}, \mathrm{Sc}$; Heidelberg) If you dream of having lost a tooth, some one in your fam. ily will die. 
If you dream that your teeth fall out, it signifies much sickness. $H 31$; cf $C S A 552$.

270. Dei beschter freind schtærbt wannnde dråmscht dū hettscht en zå ferlōe. $(S c)$

You will lose your most intimate friend if you dream that you had lost a tooth.

If you dream of having a front tooth drop out, you will lose a near relative. $C S A 552$

271. Wămmer dråmt mer grēcht en zå geroppt uns dēt ærik blüte schtærbt en ganz nēkschter freint. (Be, $L b, N a$ )

If you dream that there was profuse bleeding after the extraction of a tooth, a near relative will die.

272. Wămmer dråmt mer grēcht der federscht zå geroppt schtærbt en nēkschter freind. (Be,C,D,Lb,Lnc, $M r, S c, S n, Y$ )

If you dream of having your front tooth extracted you will lose a near relative.

273. Wạmmer dråmt mer grēcht en zå geroppt uns dēt wē, schtærbt en ferwanter oder ēns aus der familie. ' $C, D, L b, L n c, M r, \hat{M} t, S c, S n ; H e i d e l b e r g)$

If you dream of the painful extraction of a tooth, a relative or a member of your family will die.

Teeth, to dream of, are the most unlucky of all things. $H 31$

274. Wămmer dråmt mer grēcht en zå geroppt uns dēt net wē, schtærbt en freind. $(D, L b, L n c, N a, S c, S n$, $Y$; Heidelberg)

Dreaming of the painless extraction of a tooth forebodes the death of a friend.

275. Wămmer dråmt mer kennt di glēder net finne, will

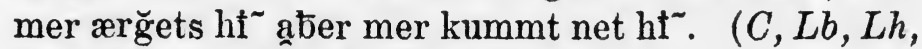
Lnc, $M r, N a, N u, Y$; Heidelberg)

Dreaming that you cannot find your clothes is a sign that you will wish to go somewhere but will not succeed. 
276. Mer hērt bąll fun re leicht wạmmer dråmt mer dēt fíl esse sēne. ( $B e, C, L b, L n c, M r, M t, N u, S n, Y)$

If you dream of a big meal you will soon hear of a funeral. Der traum von einer grossen mahlzeit bedeutet einen todesfall. $Z f D M 2.100$

Dreaming of eating portends sickness and death. $H 29$

277. Fun re hochzich dråme bedeit en leicht. (C,Lb,Lnc, $M t, N u, S c, S n, Y)$

To dream of a wedding means a funeral.

Wenn einem von hochzeiten träumt, bedeutet es einen baldigen todesfall in der verwandt- oder nachbarschaft. $Z 397$

To dream of a wedding is grief and death will follow. Ir 2. 110

278. Wạs mer Freidåknạchts dråmt wært wōr. (Nu; Kaiserslautern)

What you dream on Friday night will come true.

Friday night's dream, on the Saturday told,

Is sure to come true, be it ever so old. D Eng 243

279. Wammer dråmt fume dōde gebts wìscht wetter. $(C$, $D, L b, L h, M r . N a$; Heidelberg)

To dream of the dead is a sign of rain. $C S A 501 ; G$ Scot 29.

280. Mer grikt schtreit wạmmer dråmt fun kạtze. ( $B u, C$, Lnc, $\mathrm{Na}$ )

Dream of cats and you will quarrel.

281. Wạmmer dråmt fume schwærze gaul grikt mern brif. $(C)$

Dream of a black horse and you will receive a letter. ef. $C S A 486$

282. Wạmmer dråmt fun schlange un ferzēlts der nēkscht dåk gebts schtreit. $(L b)$

If you dream of snakes and relate your dream next day a quarrel will ensue. 
283. Wạmmer dråmt fun schląnge gebts schtreit. (Af)

To dream of snakes means enemies. C S A 474

284. Wammer dråmt fun schwærze geil gebt's schtreit, $(B u, L h, M t, S c)$

Dreaming of black horses is a sign of a quarrel. 


\section{OMENS AND WISHES}

285. Wănn em di hōrschpelle net bleibe wolle will ebber zu em schwetze. (C, Lnc, Na, Nu, Y)

If your hairpins keep coming out some one is thinking of you and wants to talk to you.

286. Wạnn en weibsmensch îr schærz flikt hot si ken glik mē. (Be, Lh, Lnc; Heidelberg)

If a woman mends her apron she spoils her luck.

287. Wạnnd iちerm kårteschpile gewinne witt, sottscht en fírblettrich glēblåt im sạk dråğe. $(L h)$

Carry a four-leafed clover in your pocket, if you would win at cards.

The possessor of the four leafed shamrock will have luck in gambling and racing. Ir 2.103

288. Wạnn mærğets en schpinn gēğich em kummt kąmmer bsuch ekschpekte. (Lb, Lnc)

If a spider comes toward you in the morning you may expect company.

289. Wạnn en schpinn mærğets gēğe em kummt grikt mer schtreit. $(\operatorname{Lnc}, \boldsymbol{Y})$

If a spider comes toward you in the morning you will have a quarrel.

290. Wammer ebber ebbes schærfes oder schpitziches schenkt, ferschneits di lib onless' si gebe der en sent. $(\operatorname{Lnc})$

Presenting anyone with a sharp or pointed gift will sever friendship unless a cent is given in return.

If a small coin or other article be given in exchange for a knife, etc. given as a present, no evil result will follow. $E Y 46$

291. Wạnn sich blōse uf der kaffii schtelle, soll mer si gråd a abschåme, sell is geld. (Af) 
Bubbles on a cup of coffee signify money.

A sediment of the sugar in the form of froth rising to the top of the cup of tea is a sign that a present of money is coming. $V S L 2.1 .318 ; C S A 714$

292. Di blōse as sich ausewennich rum uf der kaffi schtelle sin geld. $(L b)$

The bubbles collecting on coffee on the rim of the cup are money.

293. Di blōse wū sich uf der kânffi schtelle soll mer esse. $(Y)$

Eat the bubbles collecting on coffee.

294. Wạmmer færm mærğe esse nłst grikt mer seller dåk bsuch. (Be,Lb,Lnc, $Y)$

Sneezing before breakfast is a sign of company that day. $C S A 786$

295. Wạmmer ebbes winscht wann en schtærn fallt wærts wōr. ( $A f)$

A wish made when a shooting star falls will come true.

Wenn man, während man eine sternschnuppe fallen sieht, einen wunsch tut, geht er in erfüllung. $Z 1069$

If you see a shooting star, the wish you form before its disappearance will be fulfilled. $V S L 2.1 .280 ; C S A$ 458.

296. Wạmmer Sunndåks di finger oder zēe neğel ąbschneit, muss mer sich noch scheme. (Af; Lustman)

If you cut your nails on Sunday you will do something you are ashamed of before the week is out. $C S A 618$ It is unlucky to cut one's nails on Sunday. $H 54$

297. Wạmmer runde lecher in di schūsōle låft, wært mer reich. (Af)

Wearing round holes in the soles of your shoes is a sign of riches.

Wer ein rundes loch in die schuhsohle tritt wird reich. A S 1.397

To wear out shoes and stockings on the ball or sole of the foot brings money. $V S L 2.43$ 
298. Wammer sich am disch ebbes nemmt un 's fallt em, såkt mer: wǣr hot mers fergunnt. ( $A f)$

If you are helping yourself to some food at the table and it falls, you usually say: who has begrudged it to me?

Wenn ein stück brot aus der hand fällt, ist es einem nicht gegönnt. $Z 291$

299. Wann em die hand beisst soll mer si an holz reibe. $(N u)$

If your hand itches, rub it on wood.

300. Wạmme mensch di federschte ze $\bar{e}^{\sim}$ weit ausenannner schtēn, gēt er weit fun hēm. $(B u)$

A person whose incisors are far apart will travel far from home.

Wer weit auseinander stehende zähne hat, macht grosse reisen. $Z 263$

301. Wạmme weibsmensch der frak hinne nufgedrèt is soll si druf schpautze, nō grikt si en neier.

If a woman's dress is turned up in the back she should spit on it; then she will get a new dress.

302. Wạmmern lōd hoi sēnt un gråd druf winscht un di lōd nō nimmi å gukt, wært em seĩ wunsch wōr. ( $L h$, $\mathrm{Na}$; Heidelberg)

When you see a load of hay, make a wish on it; do not look at the hay again and your wish will come true.

303. Wạmmern schtrēl fạlle losst wært mer disąppoint oder mer muss sich scheme. (Lnc, Nu)

If while combing your hair you drop the comb ,you will be disappointed or have cause for shame.

....Dann gibt es was, wo einem nicht passt. Hlbg.

304. Wạnn em di nås beisst grikt mern boss. ( $L b, Y)$ If your nose itches, you will be kissed.

305. Wạnn em die nås beisst grikt mern bríf. ( $B e, D$, Lnc, $M t, N a, Y$ )

If your nose itches you will get a letter.

Beisst es einem in der nase, so erfährt man bald eine neuigkeit. $B S 33$ p. $125 ; Z 161 ; S H S 251$ 
306. Wạnn em der årsch beisst mēnts en gūt butterjōr. (Af)

An itching anus indicates a good butter year.

Juckt einem der rücken, so wird die butter wohlfeiler. Z f $D M$ 3. 175

307. Wạmmern weisser gaul sēnt sēnt mer glei en rōtkopp. $(C, D, L b, L n c, M t, N u, S c, S n, Y)$

See a white horse, meet a red head.

308. En tēleffel fạlle bedeit as mer disạpoint wært. (Be, $C, L b, L h, L n c, N a, N u, S c, S n, Y$; Freiburg) The falling of a teaspoon indicates a disappoinment.

309. Wạnn en grōsser leffel fạllt kummt en brëtmaul ins haus. $(\mathrm{Be}, \mathrm{Na})$

When a large spoon falls a braggart or an impudent person will soon appear.

....Dann kommt ein "sprichglobber". Hlbg.

310. $\overline{\mathrm{E}}^{\sim}$ håne grēt: dō is gūt wūne; der anner grēt: 's wært net lang wǣre. (Af; Freiburg)

One cock crows, it is good to be here; the other, don't crow, it won't last long.

311. Wạnn ēns ạm schpiğel schtēt un 's schtellt sich ēns hinne ans un gukt nei ${ }^{\sim}$ wærts disạppoint. (Be, Lnc, $N a, S n, Y)$

Looking over one's shoulder into a mirror will cause disappointment.

312. Wạnn ēns ạm schpiğel schtēt un 's schtellt sich ēns hinne drå un gukt nei $\sim$ muss sell sich noch scheme. ( D, Lb, Lh, Lnc, Nu, Sc; Freiburg)

Looking over some one's shoulder into a mirror will bring shame.

313. Wạnn ēns nạchts im bett nîst is di nëkscht nạcht ēns mē oder ēns wénicher. (Lh; Freiburg)

If you sneeze in bed, some one will come or depart within a day. 
314. Wạmmer mærğets gråd aus em bett schpringt wạmmer wakker wært, fallt mer noch seller dåk. (Bu, $L h, M t, N a ;$ Kaiserslautern)

Jump out of bed immediately on getting awake and you will have a fall during the day.

315. Wammer sich ebbes ạm disch nemmt wũ mer schun dåfun uf em deller hot, secht mer gewënlich: es kummt noch ebber hungriches oder årmes. (Af; Freiburg)

The taking of an article of food at the table which you already have on your plate indicates the coming of a poor or hungry person.

316. Wạnnd en schpinn $a^{\sim}$ dreffscht sottscht si ferdrike, no grikscht ken wēi hand. (Be,C,Lb,Lh,Lnc, $N u$, $S c, S n, Y)$ oders bēsding. (Mr)

Killing a spider at sight prevents sore hands; or felons.

- 317. Wǣr sich 's letscht schtik brōt uf em deller nemmit gebt en alt mēdel. (Af; Freiburg)

Whoever eats the last piece of bread will be an old maid. $C S A 1277$

318. Wạmmer ebbes nēt so âs es en ring mạcht gebts en hochzich. ( $B u, C, L h, M r, Y)$

If in sewing the material curls into a ring, it signifies a wedding.

319. Wănn em di nảs beisst kummt en schpillicher, en schtibelmann. (Be, C, Lh, Mr, Mt, Na, Sc, Sn; Freiburg)

If your nose itches it is a sign that a passionate person is coming to see you.

320. Wann der hund uf em schwanz rumfårt gebts hochzich. (D, Lnc, Y; Freiburg)

If a dog slides on his rump it signifies a wedding.

321. Wạnn en mēdel peift muss si schūr en hürekind ufztğe. (Be, Lh, Lnc, $Y$; Nürtingen)

A whistling girl will surely have a bastard child. 
322. Wạmmer der bruschtgnoche fume hinkel ferbrecht, des as es kærz schtik grikt heiert 's ērscht. (Be, $B u, C, L h, M r, M t, N a, N u, S c, S n)$; 's letscht ( $Y)$ When breaking the wishbone of a chicken, the one who gets the shorter piece will be the first to marry; the last. Whoever in pulling the merry thought of fowl apart gets the smaller half will be the first to marry. VS $L 2.332$

323. Wammer der bruschtgnoche fume hinkel ferbrecht, des, was di schipp grikt lēbt lenger as des was di gruphạk grikt, dạnns hot di schipp fer helfe 's ạnner zu begrå5e. (Be, C, D, Lb, Lh, Lnc, Mr, Mt, $\mathrm{Na}, \mathrm{Nu}, \mathrm{Y}$; Stuttgart)

When breaking the wishbone of a chicken, the person getting the longer piece will die first. (lit. the person getting the shovel will live longer than the person getting the mattock, for he has the shovel with which to help bury the other.)

324. Wạmmer uf bsuch gēt un schtolpert mit em rechte fūs eb mer ins haus kummt is mer willkomme. Wạmmer mit em linke schtolpert gengt mer besser wider hēm . (Af)

If in going visiting you stumble with the right foot you will be welcome; but if you stumble with the left foot, you had better return home at once. $C S A 1328$

Wenn man stolpert, ist man nicht willkommen. Hlbg.

325. Wănn zwē uf ēmol in der schpiğel guke wært ēns defun disąppoint. (Be,C,Lh,Lnc, Mr, Mt, Sc, $S n, Y$; Heidelberg)

Of two persons looking into a mirror at the same time, one will be disappointed.

326. Wạmmern schpiğel ferbrecht muss mern hūrekind ufzı̆ğe. (Lnc; Heidelberg)

Breaking a mirror is a sign that you will have to raise an illegitimate child.

327. Wammern schpiğel ferbrecht gebts en hochzich. (Be, $B u, L h$, Lnc. Sc; Freiburg)

Breaking a mirror forbodes a wedding. 
328. Es gebt bsuch wąnn di kạtz sich wescht. ( $A f)$

A cat washing itself foretells visitors.

Wenn sich die katzé putzt, bedeutet es einen gast. $G 3$

$72 ; B S 33.135 ; Z f D M 1.237$

If the eat washes her face-a stranger. $V S L 2.1 .306$

329. Wạnn di kạtz sich wescht un fårt ibers ōr wærts wōr. $(D, N u)$

If the cat passes her paw over the ear when washing, things will come true, i. e., visitors.

Wenn die katze sich putzt über die ohren,

Dann kommt der ritter mit stiefel und sporen. $Z$ f $D M$ 2. 102

330. Wann em di links hannd beisst grikt mer geld. ( $A f$; Heidelberg)

Itching of the palm of the left hand means that it will soon receive money. $C S A 726$

An itching palm indicates money. Ir 2. 106.

331. Wạnns fïl gnebb in der nēts gebt wammer ạm nēe is schâfft mer ane hochzichglēd. (Af)

If the thread kinks badly in sewing, it is a sign of a wedding.

Wenn beim nähen viele nadeln abbrechen, näht man an einem hochzeitskleid. Hlbg.

If cotton knots in working, speedy marriage of the person for whom the article of clothing is intended. $V S L 2$. 1. 319 ; C S A 401

332. Wănmer ebbes neies esst wū mer sell jōr noch net gesse hot kat, soll mer druf winsche, nō wærts wōr was mer winscht. $(C, D, L h, L n c, N a, N u, S c$; Heidelberg)

If you wish on the first thing you eat in the season, the wish will come true. $C S A 442$

Dann wünsehe: "so was gutes möchtest du jeden tag haben." Hlbg.

A wish is formed on first eating any fruit or vegetable for the first time in the season that produces it. $V S L 2$. 1. 180 
333. Es bedeit hochzich wạmmer di schtēk nuf fallt. (Be, $B u, C, D, L b, L h, L n c, M r, M t, N a, S c$; Freiburg)

Falling up a stairs is a sign of a wedding.

If you stumble up stairs you will be married the same year. $V S L 2.1 .321$.

334. Wạmmer di schtēk nuf fạllt grikt mer fer sibe jōr ken mannn. (Be, D, Lh, Lnc, Sc; Freiburg)

Tumble up stairs and you will not get married within seven years.

Tumble up stairs and you will not get married within the year. $C S A 377$

335. Wạnn em di fūssōl beisst bedeits ans mer uf neier grund kummt. ( $B e, B u, C, L b, L h, N a, N u, S n, Y$ )

If the sole of your foot itches you will walk over strange ground.

The itching of the sole of the foot is an omen that you will walk over strange ground. $V S L 2.1$. 285; $S \& C S 13$

336. En tēblått in seim tē finne mēnt bsuch; wạnns hært is, kummt en mạnnskærl; wạnn wēch, en weibsmensch.

If you find a tea stem in the tea, it is a sign you will have a visitor. If it is hard, it is a man; if soft, a woman. $C$ $S$ A 776

Wenn man ein teeblatt in dem tee findet, pflegt man zu sagen: "das bedeutet auch wieder besuch". Hlbg.

A floating teastalk indicates a beau. $V S L 2.1 .318$

337. Wạnn der håne zu der dîr nei grēt gebts bsuch. ( $A f$; Heidelberg)

If the cock crows into the room you may expect visitors. The crowing of the cock on the threshold indicates the arrival of strangers. $G S \operatorname{scot} 140 ; C P \& P 549$

338. Sing fer site un du heilscht fer elfe. $(C, D, L b, L n c$, $M t, N a, S c, Y$ )

Sing before seven

Cry before eleven.

Wer am morgen lacht, weint am abend. $Z 32 \bar{\tau}$ 
It was accounted unlucky to sing before breakfast. $G S \operatorname{Scot}$ 31 ; C S A 1316

339. Wănn zwē sich aus em sēme wăsser wesche wærn si schtreitich fer nacht. ( $A f)$

Two persons washing in the same water will quarrel before night.

Wenn zwei menschen sich in demselben wasser waschen, gibt es streit. $W u 314$

If two persons wash their hands together in the same basin they will be sure to fall out before bed time. $H N C 112$

340. Wănn sich zwē aus em sēme wassser wesche, fechte si wanns zwet nei schpaut. $(B u, D, L n c, N a, N u$, $Y$; Heidelberg)

If two persons use the same water to wash they will quarrel unless the one who washes last spits into the water.

Wash in the same water with another and you will fall out before night. Either spit in the water or make a cross in the soapsuds. $V S L 2.157$

341. Mer soll sich net zu zwet an sēme handduch a abdrikle eksépt mer drēts rum, schunscht wært mer schtreit. ich. $(A f)$

When two persons wipe their hands on the same towel they will quarrel unless the second one turns it.

Wenn zwei menschen sich an demselben handtuch abtrocknen, werden sie einander feind. $W u 405$

342. Wămmer ēnich ebbes letz å dut grikt mer ebbes gschenkt. (Af)

If you put on a garment wrongside out, you will receive a present.

Wer ein kleidungsstück verkehrt anzieht, hat glück. $A$ $J 250$

In case an article of dress is put on accidentally inside out, it is an omen of success. $D Y$

343. Wạmmer mit em linkse fūss 's ērscht aus em bett gẽt, gēt es seller dåk alles letz. ( $A f)$

If you get up with your left foot first, everything will go wrong that day. 
Wer mit dem linken fuss zuerst aus dem bett steigt, dem geht den ganzen tag alles verkehrt. $B S 33.213$

344. Wạnn ēns gridlich is såkt mer : du bischt 's hinnerscht

's féderscht ufgschtanne. (Af; Heidelberg)

One says to a person who is crabbed: "You got up out of bed wrong".

Wer rücklings aus dem bett steigt, dem geht den ganzen tag alles verkehrt. $B S 33.213$

345. Wạmmer mærğets hinnerschich aus em bett gēt, gēt em seller dåk alles 's hinnerscht federscht. ( $A f)$ Things will go wrong all day if you get up backwards.

To get out of bed with the left foot first, renders you cross and unfortunate all the day. $E Y 44$

346. Wann em der schærzbendel ufgēt, denkt ebber an em. (Be, C, Lb, Lh, Lnc, Mr, Mt $, \mathrm{Na}, S n, Y$ )

If your apronstrings become untied, some one is thinking of you.

Wenn ein mädchen den schurz verliert, oder das strumpfband, sagt man, der schatz habe dran gedacht. $V A S$ 1. 478

To lose your apron or garter shows that your lover is thinking of you. Corn 165; $C S A 364$

347. En pok uf der zung bedeit âs du geloğe hoscht.. Schpau nō drei mol ins feier un si gēt wek. $(N u, S n)$

A pimple on the tongue indicates that you have told an untruth. Spitting into fire three times will cause it to disappear.

Wer blasen auf die zunge bekommt, wird sogleich belogen, er soll dreimal ausspeien und dem belüger alles böse anwünschen. $G 3.311$

A blister will rise upon one's tongue that tells a lie. $V$ $S L$ 2. 1. 296

348. Mit re hausdír oder me schtūl zu schpìle bedeit schtreit in der familie. ( $\mathrm{Be}, \mathrm{Lh}, \mathrm{Na}, \mathrm{Sn}$; Heidelberg)

To play with a door or twirl a chair implies a family quarrel. 
To twist a chair round on its legs indicates a quarrel. $V S$ L 2. 157 ; C S A 1279

349. Si såğe mer grēcht schlēk wạmmer mit re hausdìr oder me schtūl schpile dēt. $(B e)$

To play with a door or a chair forebodes a whipping.

Twirling an empty chair indicates that a whipping is in store for the transgressor. $C S A 1280$

350. Wann ēns fîl kạffi grauns im koppche hot muss es fil heile. $(C, L h, S c, S n)$

Many coffee grounds on the bottom of the cup forebode many tears.

Wann viel kaffeesatz im kumchen ist, muss man viel greinen. Hlbg.

351. Wạmmer fergesst wạ mer såğe hot wolle wårs geloğe. (Af)

Forgetting what you were about to say is an omen that it was an untruth.

Wer während des sprechens vergisst, was er sagen wollte, war im begriff, eine lüge zu sagen. $B S 33$ p 136

352. Wăs de winscht uf di ērscht schtærn as de sēnscht

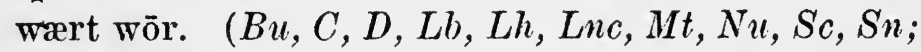
Heidelberg)

A wish made at the sight of the first star will come true.

353. Wann em der schpillumbe făllt is es ērscht wü kummt en schlạpp, oders gēt ēni fært oder wannn keni kummt is mer si selbært. ( $A f)$

If you drop the dishcloth it is a sign that a slovenly person is coming or leaving, or, in case nobody turns up, you are the sloven yourself.

354. Wǣrs kærz end fum bruschtgnoche grikt muss 's ërscht schokle. $(S c)$

The one who gets the short end of the wishbone will be the first to rock the cradle, 
355. Wạnn en dischmesser éநerschich uf em disch leit, gebts schtreit in der fạmilie. ( $B u, L h, M t, S n)$

A tableknife lying with the edge turned up forebodes a quarrel in the family.

Es ist nicht gut, dass man ein messer auf den rücken lege. G $R 369$

356. En flō uf der hạnd, en briff fum lạnd. (Lnc)

A flea on your hand, a letter from the country.

Ein floh auf der hand, ein brief vom land. $Z 236$

357. Wạnn noch roifēdem ime frak sin wạmmern a ${ }^{\sim}$ dut, is er noch net bezålt. (Af; Freiburg)

Putting on a dress with bastingthreads still in it means that it is not paid for.

358. Wạmmer dærich en schpinnewēb låft grikt mer băll en neier. $(L n c)$

Putting on a dress with bastingthreads still in it indicates that you will soon get a new one.

359. Wanmer dærich en schpinnewēb låft drefft mern

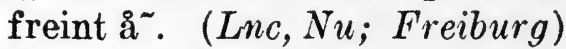

If you walk through a spider web you will meet a friend.

360. Wănn en schpekmaus ins haus flikt is der deibel dernōch. (Lnc, Sn; Heidelberg)

If a bat flies into your house the devil is after you.

361. Me gerechte reğerts ins gråb, me ungerechte in di hochzich. (Be,C, D, Mr, Na, Sc, Sn, Y Heidelberg)

It rains on the funeral day of the righteous, and on the wedding day of the unrighteous.

362. Wann iøerm nēe di nōdel ferbrecht, heiert des, fer des às mers glēd mạcht, ebs glēd ausgewōre is. (D), Lnc, $\left.Y_{\mathrm{i}}\right)$

If a needle breaks while sewing, the person for whom the dress is being made will be married before it is worn out. Bricht man drei nadeln ab beim nähen eines kleidungs. stückes, so wird die trägerin braut darin. A A 5 
363. Wạmmer ann ebbes denkt un ntst debei wærts wör. (Af) Sneezing while thinking of something is a sign that it will come true.

Beniessen eines vorfalles bedeutet dessen bestätigung. $L V 232$

364. 'S gebt bsuch wannn en schēr uf der bode fallt un bleibt schteke. $(\mathrm{Bu}, \mathrm{Mr}, \mathrm{Mt}, \mathrm{Na})$, odern messer. $(\mathrm{Be})$

A pair of scissors or a knife falling to the ground and sticking fast indicates visitors.

Wenn eine schere oder ein messer auf den boden fällt und mit der spitze stecken bleibt, kommt ein besuch. $Z$ 244; $C S A 757$

365. Wann der hund sich in der schtub rollt bedeits bsuch. (Af; Heidelberg)

A dog rolling on the floor indicates visitors.

366. Wann der hund der kærpet ufkikt, gebts bsuch. (Nu; Heidelberg)

If the dog disarranges the carpet, you will have visitors.

367. Sō fîl fleke as mer hot uf de fingerneğel, so fîl jōr lēbt mer noch. (D, Lb, Lnc, Na, Y; Heidelberg)

The number of spots on your fingernails indicates the number of years that you still have to live.

To have white specks on one's fingernails shows that happiness is in store. $H 51$

368. Sō fíl fleke às mer uf de fingerneğel hot, sō fil presents grikt mer di Grischdåk. ( $D, L n c, M t, S n)$

You will receive a Christmas present for each white spot on your fingernails.

Blumen, $d . h$. flecken auf dem daumen bedeuten geschenke oder einen gewinn an der lotterie. BS 33.138

White specks on one's fingernails are sometimes called gifts. $I I 51 ; C S A 116$

369. Der deibel gukt raus wạmmer nachts in der schpiğel gukt. ( $B e, B u, C, D, L b, L h, N u, S n, Y$ )

The devil stares at you when you look into a mirror at night. 
Welcher des nachts in einen spiegel sieht, der sieht den teufel darin. $Z$ f $D M 3.315$

To look into a mirror at dusk or nighttime, unless the room is well lighted, is not pleasant: for there is a dread of something uncanny peeping over the shoulders; such an apparition would portend death. $H 56$

370. Fil mike im summer, fil granket. (Bu, $Y$; Kaiserslautern)

Many flies, much sickness.

371. Wạnns im summer fìl mike hot is ganz wénich granket. (Af)

Many fiies in summer, little sickness.

There is a superstition in Italy that when there are no flies in summer the cholera is sure to come. $V S L$ 2. 627

372. Mer soll net ōbeds in der schpiğel guke oder mer gukt em deibel in der årsch. ( $B e, B u, C, D, L b, L h, M r$, $N a, N u, S c, Y$ )

You will look at the devil's rump if you look into a mirror at night.

Wenn man bei der nacht in den spiegel sieht, schaut der teufel heraus. $Z 314 ; G 3.104$

It is ill luck to see one's face in the mirror by candle light. $V S L 2.173$

373. Wạnn ems ōr brennt denkt ebber an em. (C, Mt, Sc) $M t, S c)$

If your ear burns, someone is thinking of you.

If the ear tingles somebody is talking about you. $S \& C$ $S 13$

374. Wạnn ems links ör beisst schwetzt ebber schlecht fun em. $(A f)$

If your left ear burns, some one is speaking evil about you. Böses wird von einem gesprochen, wenn ihm das linke ohr klingt. $Z 195$

If one's left ear burns, then the friends are "picking holes in one's jacket." $H 59$ 
375. Wann ems recht ōr beisst schwetzt ebber gūt fun em. (Af)

If the right ear itches, some one is speaking well of you. Klingt einem das rechte ohr, wird gut von einem gesprochen. $Z 194$

If one's right ear gets very hot it shows that one's friends are speaking in laudatory terms of one. $H 59$

376. Wannn ems links ōr brennt, beisst mer in der schærz un såkt: ich hoff du beisscht der in di zung. (D, $L n c, M r, Y$ )

If your left ear burns, bite your apron and say: I hope you will bite your tongue.

Wenn einem die ohren klingen, so beisst man in den linken rock- oder schürzenzipfel oder in den ellbogen, so beisst sich der verleumder auf die zunge. $W u 287 ; G 3.802$

When your left cheek burns, some one is abusing you. A knot tide in the apron-string will cause the slanderer to bite his or her tongue. Corn $170 ; C S A 1342$

377. Wạnn en gạbel fallt kummt en mąnnskærl. ( $A f)$

If a fork drops, the visitor will be a man. $C S A 764$

378. Wạnn en butschermesser fallt kummt der parre. (Be, $C, D, L n c, N a, N u, S c, Y)$

If a butcherknife falls it is a sign of a visit from your pastor.

379. Wann en messer fallt kummt en weibsmensch. ( $A f$; Freiburg)

If a knife is dropped a woman will come.

If you drop a knife, it is a sign a lady is coming to see you. $C S A 764 ; D Y 105$

380. Mærğets wạmmer ufschtēt muss mer der rechts fūss 's ērscht å dũ $\sim$, schunscht grikt mer schtreit eb ōbed. (Be, Bu, Lb, Lh, Lnc, Nu, Sc, Sn, Y ; Freiburg)

Upon getting up in the morning, clothe the right foot first to avoid a quarrel during the day.

To elothe the left foot before the right is a sign of misfortune. $D Y 85$ 
381. Wănn zwē leit minnannner ebbes såğe kummt noch en ēsel. (Lh; Kaiserslautern)

If two persons say the same thing at the same time you may expect an ass.

382. Wammern butze fume inschlichlicht mit em finger a abroppt un er brennt em net gleicht sell mēdel em wū mer selli zeit drå denkt. ( $B e, B u, L h, L n c, M r, N a$, $S c, S n, Y)$

If you can snuff a tallow candle with the fingers without burning them, the girl whom you are thinking of at the time loves you.

383. Wạmmer iøers greitz hąnds schēkd gebts hochzich. (Lnc, Na, Sc, Sn, Y ; Heidelberg)

If you cross arms in shaking hands it is a sign of a wedding.

384. Wạnn en schpinn gēğich em kummt oder is uf em kąmmer bsuch ekschpekte. (Lb, Lnc; Heidelberg) If a spider comes toward you or gets on you, you will get company.

385. Wammer di hose uf de gnì dærich wērt wært mer reich. $(D, M t, S n)$

Wearing holes into the trousers at the knees is a sign of riches.

386. Wammer di hose uf em sitz dærich wērt wært mer årm. $(C, D, M t, S c, S n)$

Wearing holes into the seat of the trousers is an omen of poverty.

387. Wammer ebbes esst as mer sell jōr noch net gesse hot kat, soll mer druf winsche; was mer winscht wært wōr. $(C, D, L h, L n c, N a, N u, S c)$

When eating anything for the first time in a season, make a wish and the wish will come true.

.....man wünscht, so was gutes möchte man jeden tag haben. Hlbg. 
388. Wạmmer Mūndåk mærğets fer de nein ūr geld grikt, grikt mer fill selli woch âter wammer ausgebt fær de nein ūr muss mer selli woch fill ausgebe. $(A f)$

If you receive money on Monday morning before nine, you will receive money all week; but if you pay out money before nine on Monday morning you will have to pay out money all week.

389. Der butze fum fettlicht weist weller wēk as em sei $\sim$ bõ hǣrkummt. (Be,C, D, Lb, Lh, Lnc, $\mathrm{Mt}, \mathrm{Na}, \mathrm{Nu}$, $S n, Y)$

The wick of the lard lamp indicates the direction from which you may expect a beau.

......oder bẹsuch. Heidelberg.

390. Wann em di nås beisst grikt mer en boss. ( $B u, L b$, Lnc, $S n, Y$ )

If your nose itches, you will be kissed.

If your nose itches, you will be kissed by a fool. $V S L$ 2. 1.284

391. Wann em di nås beisst grikt mer schtreit. ( $B u, C, D$, $L h, L n c, M t, N a, N u, S c)$

If the nose itches it is a sign of a quarrel.

Juckt einem die nase, so reizt man einem zum zorn. $Z f$ $D M 3.175 ; C S A 1355 ; V S L 2.1 .284$.

392. Wạnn em di nås beisst wært mer bēs seller dåk. (Mt) If your nose itches you will become angry during the day. Itching of the nose is an omen that you will be crossed. $V S L 2.1 .284$

393. Wann em die nås beisst grikt mern brìf. $(A f)$

If your nose itches, you will receive a letter. $C S A 1361$ An itching in the nose indicates that a letter is lying in the postoffice for you. $G S \operatorname{Scot} 2 \bar{\tau}$

394. Wạnn ems recht åk beisst sēnt mer ebbes gǣrn; es links, net gærn. (Af)

If your right eye itches you will see something pleasing; the left, something disagreeable. 
Wenn einem vormittags das rechte auge beisst, so wird man etwas gern sehen; wenn das linke, so hat man leid. Wu 218

Itching of the right eye-you will laugh; itching of the left, you will cry. $V S L 2.1 .286 ; C S A 1349,1350$

395. Sō fíl dubbe às mer uf de fingerneğel hot, so fîl jōr lëbt mer noch. $(D, L b, N a, N u, S c)$

The number of spots on your fingernails indicates the number of years you will live.

So viele weissen "dubbe" auf den fingernägeln, so viele jahre muss man warten, bis man heiratet. Hlbg. 


\section{LUCK AND OMENS OF LUCK}

396. Năğel en hūfeise őich di dir fer glik. $(B e, B u, L h$, Mt)

Nail a horseshore over the door for luck.

Ein auf der strasse gefundenes hufeisen, welches auf die haustür genagelt wird, mit der offenen seite nach aussen, ist eine mächtige schutzwehr gegen alle bösen geister.... $W u 130$

397. Wann em en loch in der schærz brennt grikt mer druந̄el wūs loch is. Wanns fanne is kummt der drubel; wann hinne, is er ferbei. (Lnc, Nu; Heidelberg)

A hole burned into an apron is a bad omen. If the hole is in the front of the apron trouble and sorrow are in store for you; if in the back, they are past.

398. En schaufel oder grubhak ins haus zu nemme bringt schlecht glik. (Nu; Kaiserslautern)

It is unlucky to take a shovel or mattock into the house.

399. Wanns ērscht as di neijōr in em sei $\sim$ haus kummt en weibsmensch is bedeits unglik fer sell jōr; en mann, glik. (D, Lnc, $Y$; Heidelberg)

If the first visitor on New Year's is a woman, you will have bad luck all year; if a man, good luck.

Cf. $V A S 1.469 ; Z f D M 2.421$

400. Wạmmer dehēm færtgēt fær uf bsuch gẽ un 's schpringt em en kântz iøer der wēk gengt mer juscht so gūt hēm. $(Y)$

If when leaving home to make a visit a cat crosses your path you would just as well turn back.

401. Wạmer schisse gèt un's schpringt en kạtz fær em iber di schtross dēt mer besser rumdrēe un hëm gē̃ $(B e, C, D, L b, L n c, M t, N a, N u, S n, Y$ )

If a cat crosses your path when starting out to go hunting, you would better turn back. 
402. Wammern schwærzi kạtz schpōt nachts å drefft bedeits schlecht glik; en weissi, gūtes. $(B e, B u, C, D$, $L b, L n c, M r, M t, N a, S c, Y$ )

Meeting a black cat late at night indicates bad luck; a white one, good luck.

Eine über den weg laufende katze, besonders eine schwarze, bedeutet unglïck. $W u 200$

403. En schpinn dōdmạche bringt em schlecht glik. (Bu, Mt)

Killing a spider brings bad luck.

Man darf vormittags keine spinne töten. Wu 206

404. Mer dærf bei leiøe net uf en pēment grēt drēte, oder mer hot unglik. (Lnc; Heidelberg)

Absolutely never step on a grating in a pavement, it brings bad luck.

405. Es bedeit gūt glik wạmmern freint net gråd kennt wammern å drefft. (Lnc; Heidelberg)

It is a sign of good luck not to recognize a friend alone.

40\%. Wămmer em Hōman sei ${ }^{\sim}$ buch net im haus hot hot mer ken glik. $($ Lnc,$Y)$

The possession of Hohmann's "Long Lost Friend" brings good luck.

407. Mer dærf net unich me geilskopp dærich schluppe, mer hot ken glik. ( $L b, L n c, M r, S c, Y)$

To pass under a horse's head brings bad luck.

Wenn eine schwangere frau zwischen dem leib und dem kopf eines tieres durchgeht, so kann sie dann nicht gebären, wenn sie nicht während der geburtswehen wieder zwischen dem leib und dem kopf eines tieres rückwärts durchgeht. $L 369$

408. Iber ebber sei schulter in der schpiğel guke bringt schlecht glik. (Be, C, Lnc, $\mathrm{Mr}, \mathrm{Nu}, \mathrm{Sc}, \mathrm{Y}$; Neustadt) Looking into a mirror over some one's shoulders brings bad luck. 
409. Wămmer nìst bedeits gūt glik un mer såkt als : gsund. hēt. ( $A f)$

Sneezing presages good luck and the customary salutation is : "Your health!"

The customary salutation is: "God bless you." $C P \& P$ 540 .

410. Wănn en weibsmensch der schærz ąxidentąlly letz å dut grikt si ebbes geschenkt. (Mt; Heidelberg) Putting on an apron wrongside out by mistake presages a gift.

411. Wănn en weibsmensch der schærz unwissend letz å dut is si gliklich. Wann si en rumdrēt gebts en unglik in der familie. (Af; Heidelberg)

Accidentally putting on one's apron wrongside out is lucky ; turning it will bring accident or misfortune.

412. Wammer geld finnt soll mers net ausgebe oder mer gebt sei ${ }^{\sim}$ glik wek. $(B e, B u, C, D, L b, L h, L n c, M r$, $N a, S c, S n$ )

To find money and keep it insures good luck. $C S A 718$ It is ill luck to keep found money, therefore it should be spent. $\quad C P \& P 531$

413. Der links hinnerscht fūss fume hås ås mer nachts ime kærichhōf schisst bringt em glik wămmern nōdråkt. $(B e, D, L b, L h, L n c, M r, N u, S n, Y)$

Wearing the left hind foot of a rabbit shot at night time in a cemetery brings good luck.

Die pfoten des flüchtigen und mit offenen augen schlafenden hasen auf dem leib getragen sind für den rekruten ein mittel, militärfrei zu werden; sie bringen, neben das kopfkissen gelegt, gesunden schlaf. $B M 21$

414. Wạnn di fenschtre schittle un 's is net windich, oder der ofe gracht, oder wănns ēnichi zucht im haus gebt wū ken ürsach derför is gebts en unglik $(C, D, L b$, Lnc, $M t, N a, N u, S c$; Heidelberg) ; oder schtærbt ebber. $(Y ;$ Heidelberg $)$ 
If the windows rattle and it is not windy, or if the stove cracks, or if there is any inexplicable noise in the house, it forebodes accident or death.

415. En lërer dōdewăğe å dreffe bedeit unglik; en gfillter, glik. (Be, Lnc, Sc;Heidelberg)

Meeting an empty hearse is unlucky; one containing a corpse, lucky.

416. Wạmmer sich mærğets å dut uns reisst en gnopp a্রb, bedeites en unglik seller dåk. (Lnc, Y)

Tearing off a button when dressing in the morning is a bad omen.

Wenn morgens beim ankleiden ein knopf losbricht, bedeutet es unglück für den betreffenden tag. $Z 241$

417. Wạnn en kântz ân em vorbei gēt is es gūt glik; en hund, schlecht. (Nu;Freiburg)

A cat passing you brings good luck; a dog, bad luck.

41.8. Gewittere uf der Himmelfærdåk bringe unglik. (Lnc) Thunderstorms on Ascension Day bring bad luck.

419. Wạmmer drei lōges fliğel in der hūt dut hot mer fîl glik ebbes zu finne. ( $L h)$

Wearing three locust wings in one's hat gives exceptional luck in finding things.

420. Wămmer gens å drefft bedeits en unglik. (Be, Lnc; Kaiserslautern)

To meet geese is a sign of bad luck.

421. Wănn em sei fingerneğel weisse blakke hen blits hols noch fer em sei låd. ( $B e, C, L b, L h, L n c, N a, S c)$ White spots on the fingernails indicate that the rood for one's coffin is still in the tree.

Wer an den daumennägeln weisse flecken hat, bleibt in seinem vaterland. $G 3.1070$

Weisse flecken auf den nägeln der rechten hand bedeuten glück. $Z 191$

422. Wạn em di rechts hạnd beisst grikt mern haudidü'. (Af) 
If your right hand itches you will shake hands with some one.

Itching of the right hand indicates that one is soon to meet a stranger with whom he will shake hands. $S H S 259$

423. Wănn di hinkel grēe un di weibsleit peife is es en schlechti sein. ( $A f)$

It is a bad omen to hear a hen erowing or a woman whistling.

Wenn ein mädchen pfeift, so weint unsre liebe frau. $Z f$ $D M 430$

A crowing hen, a whistling girl and a black cat are considered most unlucky. Ir 2.63

424. Wạmmer ime fasst hot mer güt glik, aber mer muss si ærğets schunscht bei gríğe. (Be, Sc, $Y$; Kaisers lautern)

It is a sign of good luck to hive stray bees.

It is considered lucky for a stray swarm of bees to settle near your house. Corn 137

425. Wannn re frå der schærz ufgèt un er fạllt re ấ, ferlirt si fr mann. (Be, C,Lh, Lnc, $M t, N a, N u, Y)$

If a woman's apronstrings become untied and the apron falls to the floor she will lose her husband.

Verliert ein frau oder magd auf der gasse das strumpfband, so ist ihr der mann oder freier ungetreu. $G 3.124 ; C$ $S A 365$

426. Wạmmer di schtrimp unbedenkt letz å dut grikt mer ebbes geschenkt. ( $D, L b, L n c, S n, Y$; Heidelberg) Accidentally putting on the stockings wrong side out means a present.

It is lucky to put on stockings wrongside out, but unlucky to turn them on discovering the mistake. $D Y 85$

427. Wămmer der schærz letz å dut, soll mern so losse oder mer tschëntscht sei glik. $(B u, C, D, L b, L h, L n c$, $S c, S n, Y$ )

Changing an apron put on wrong side out alters the luck. Changing a garment put on wrong side out alters the luck. VSL2.28 
428. Wạmmer uf me greizwēk geld finnt, soll mers leie losse, schunscht hot mer unglik. (Be, Bu,C,Lb, Lnc, $\cdot M t$ )

Never pick up money from crossroads, it will bring bad luck.

Wenn man auf einem kreuzwege geld findet, soll man es liegen lassen. $Z 319$

It is a bad omen to find money. $D Y 132 ; C P \& P 477$

429. Wạnn em di recht hand beisst grikt mer seller dåk noch geld. (Af; Heidelberg)

If the right hand itches, you will receive money. $C S A$ 724

Itching of the palm of the right hand indicates a gift. $V S L 2.1 .283$

430. Wạnn en komēt' ąm himmel schtēt gebts grìk. (Af)

A comet is a sign of war.

Ein komet bedeutet krieg. $Z$ Z $1065 ; W u 196$

Comets announce the approach of wars, seditions, changes of kingdoms and the like. $V S L 2.556$

431. Wạmmer mol dehēm ạbgschtǣrt hot fer ærğets hĩ gē un mer hot ebbes fergesse, soll mer net zurikge $\bar{e}^{-}$ fers hōle, oder mer hot ken glik. ( $A f)$

It is unlucky to turn back for anything after you have set out.

Wer aus dem hause geht und etwas vergessen hat, darf nicht wieder unkehren um es zu holen, sonst hat er an dem tage kein glück. Braucht er das vergessene notwendig so muss er es durch einen anderen holen lassen. B $S 33.139$

It is ill luck to go back for any purpose after having set out. $V S L 2.172 ; C S A 656$

432. Wạmmer sich ąber im haus hĩ hokt wạmmer zurikgange is ebbes $\mathrm{zu}$ hōle nochdem as mer schun

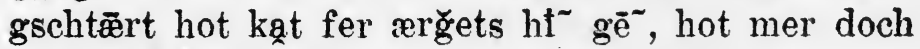
glik. $(D, L b, L h)$ 
If you sit down for a moment when you return home to get something which you had forgotten until after you had set out, you will avert misfortune.

If however you are compelled to it, fail not to sit down. It averts some of the evil. $V S L 2.172 ; C S A 658$

433. Wămmer ferrēst' soll merm ērschte bettelmannn ăs mer å drefft en dåler gebe, nō hot mer glik. ( $L h, \mathrm{Na}$; Heidelberg)

You will have a successful journey if you give a dollar to the first beggar whom you meet.

It is bad luck to refuse charity to a beggar woman, when setting out on a journey. $V S L 2.161$

434. Unnere lēder dærich låfe bringt schlecht glik. ( $L b$, Lnc, Mr, Sc; Heidelberg)

Passing under a ladder brings bad luck.

Dr. Johnson objected to going under a ladder. $C P \& P$ 478

It is ill luck to walk under a ladder set against a wall. $V S L 2.162$

435. Wammern rōtkopp å drefft un sēnt net glei en weisser gaul gebts en unglik. $(B u)$

If you meet a redhead and do not soon see a white horse you will have an accident.

To meet a man with red hair or a woman with a red petticoat the first thing in the morning forebodes evil. Ir

2. 114

436. Mer dærf ken omberell' im haus ufschpanne schunscht gebts en unglik. (Af)

Opening an umbrella in the house means bad luck.

Es gibt streit. Hlbg.

Opening an umbrella in the house brings trouble to yourself or the inmates. $V S L 2.148 ; C S A 705$

437. Schwalme soll mer keni schisse oder dōdschlą̆ge, mer hot ken glik. $(A f)$

You will have no luck if you shoot or bill swallows. 
Man soll keine schwalben schiessen, denn das bringt unglück. $Z$ f $D$ M 2.420

It is unlucky to kill a swallow. $I I 54$

438. Wạnn em nạchts di zwē ōre singe bedeits gūt glik. $(\mathrm{Nu})$

Both ears tingling at night is a good omen.

Both left and right

Are good at night. $C S A 1347$

Tingling of the ears, you will hear sudden news. $V S L$ 2. 1.286

439. Wănn en fremmer mannn anme haus zu ēnre dîr nei gēt un zū re annere naus, nemmt er de leit îr glik mit. (Af; Heidelberg)

A stranger entering your home by one door and leaving it by another takes away your luck.

440. Wạmmer in en haus gēt soll mer sich setze oder mer nemmt de leit di rū. $(B e, D, L b, L h, L n c, S c, S n, Y)$ Always sit down when you enter a house or you will rob the family of its peace.

Wenn man jemand in seinem hause besucht soll man sich setzen, sonst nimmt man die ruhe mit. $B S 33.135$

441. En fremmer mạn muss sich immer hî̃ hoke wạnn er an en fremm haus kummt oder er nemmt de leit di rū. $\quad(B e, D, L b, L h, L n c, M r, N a, S c, S n, Y)$

On entering a house a stranger must always be seated or he will rob the family of its peace.

Geht ein fremder aus dem zimmer ohne sich gesetzt zu haben, so nimmt er ruhe und frieden mit fort. $A A 15$

442. Wann en hund unich me fenschter heilt bedeits unglik. $(B e, D, L b, L n c, M t, N a, S n)$

The whining of a dog beneath a window is a sign of bad luck.

Hundeheulen bedeutet unglück. $G 3.159$

443. Wạnn dern schwærzi kătz iøer der wēk låft gebts en unglik. $(B u, C, L b, M r, M t, N a)$

If a black cat crosses your path it is a bad omen. 
It is an Irish superstition that if you go on a journey and meet a cat you should turn back. $I r 2.20$

444. Mer hot glik seller dåk wạmmer mærğets drei mōl nfsst. $\quad(B e, L n c, M t)$

Sneezing thrice in the morning brings luck for the day.

Wenn man früh morgens dreimal niest bedeutet es glück oder eine angenehme überraschung. $Z 234$

445. Mer dærf nìmand as færtgēt nō'guke oders hot ken glik. $(L n c)$

Never watch a person out of sight, for it will bring bad luck.

It is unlueky to watch any one out of sight. $H N C 117$; C S A 1304

446. Wąnn en schpinn mærğets gēğich em kummt bringt si em glik seller dåk. (Bu,D,Lb,Lh,Lnc, Mt,Sn,Y) A spider approaching you in the morning is an omen of good luck.

Eine spinne, welche sich dem menschen des morgens nähert (ihm in den weg läuft) bringt glück, des nachmittags un. glück für den tag. $B S 33.135 ; G 3.134$

When a spider is found on our clothes we use to say, some money is eoming toward us. $H N C 111$

447. En grixel ime haus mēnt glik. (Be, $D, L b, L n c, M t)$ oder unglik. $\left(\mathrm{Be}, \mathrm{S}^{\prime} \mathrm{c}\right)$

$A$ cricket in the house is an omen of luck or of misfortune. Grillen in dem hause bedeuten glück. $Z 783 ; G 3.313$

The cricket is looked upon as the most lucky inmate of a house and woe to the person who may happen to kill one. W Ir. 74

448. Wănmern schpel ufhēbt mit em kopp gēğich em hot mer unglik. (Lh, Sc, Sn)

Picking a pin with the head toward you will bring bad luck.

Man darf kein spitziges ding aufheben. Hlbg.

449. Wạnn en schpel uf em bodem leit mit em kopp gëğich em bedeits glik. ( $B e, C, L b, M r, N a, S n, Y)$ 
A pin on the floor with the head toward you brings good luck.

450. Wămmern schpel sēnt leie mit em schpitzich end gëgich em is es glik. ( $L b)$

It is lucky to see a pin lying with the point toward you.

451. En schpel ufhēbe bringt glik. (Af; Heidelberg)

Picking up a pin brings good luck.

See a pin and pick it up,

All the day you'll have good luck. $S \& C S 9 ; D Y 98$

452. Wammern finfblettrich glēblått finnt hot mer fill glik. $(B e, B u, L h, L n c, M t, N u)$

To find a five-leafed elover is very lucky.

Gegen verhexung soll gut sein, wenn man fünfblätterigen klee bei sich trägt. $V A S 1.330$

453. Wạmmern finfblettrich glēblåt finnt hot mer ken glik. $(C, D, M r, N a, S c, S n)$

To find a five-leafed clover is unlucky. $C S A 699$

Wenn man einen fünfklee findet, bedeutet es unglück. $Z 924$

454. Es gebt en unglik wạmmern finfblettrich glēblåt finnt. $(N a, S n)$

Finding a five-leaved clover is a sign of bad luck.

455. En schrēksåğicher mann å̃udreffe bedeit glik. (Be, C, Lnc, $\mathrm{Na}, \mathrm{Y}$; Neustadt)

Meeting a crosseyed man brings luck.

It is good luck to meet a squinting person of the opposite sex. VSL 2.20

456. En schrēksåğicher mannn å dreffe bedeit unglik.

$(S n)$

Meeting a crosseyed man means bad luck.

457. Es bedeit unglik en schrēksåğichi frå å zudreffe. (Be,C,Lnc, Na, $Y$; Neustadt)

It is bad luck to meet a cross-eyed woman.

It is good luck to meet a squinting person of the opposite sex. $V \& S I, 2.20$ 
458. Wạmmer di schtēk nuf fạllt hot mer glik. (Be, Lnc, $N u, Y$ )

Falling up steps brings good luck.

To tumble up stairs brings good luck. $V S L 2.20$

459. Wạnn mærğets 's ërscht âs ins haus kumt en mạnnskærl is hot mer glik. (Be, Lnc; Heidelberg)

If the first person to visit you in the morning is a man, it will bring you good luck.

It is unlucky to meet a cat, dog or woman when going out first in the morning. Ir 2. 105

460. Wạmmer schpōtjōrs der șąfron net raus roppt un uf di schtrōss schmeisst hot mer ken glik. ( $L b)$

If saffron is not pulled in fall and thrown into the street you will not have good luck.

461. Wammern schpel oder ēnich ebbes schpitziches, odern messer geschenkt grikt, muss mers mit me sent bezåle, schunscht bringts em schlecht glik. $(B e$, $C, D, L n c, M r, S c, S n, Y$; Heidelberg)

A pin or anything pointed or a knife, given as a present, will bring ill luck unless a cent is paid as recompense. Var. Mer muss si èrscht in der rokærmel schteke un no nemme. $(\mathrm{Nu})$

Stick it into the coatsleeve before accepting it.

462. Wạnn dern weissi katz iber die schtrōss schpringt, gengscht besser wider hēm. (Lnc)

If a white cat crosses your path, you had better turn back.

463. Wạnn dern schwærzi kạtz iber di schtrōss schpringt, gēscht besser wider hēm. $(M r, N u)$

You had better turn back if a black cat crosses your path.

464. Wạnn em en hås iter die schtrōs schpringt, bedeits unglik, ą̋er wanner di schtrōs naus fær em hæ̋r schpringt bedeits glik. (Lnc, $\mathrm{Na}, \mathrm{Sc}, \mathrm{Y}$; Heidelberg)

A rabbit crossing your path is an omen of ill luck; but if it runs along ahead of you, good luck. 
465. Di zwẽ schtrimp soll mers erscht å dū̃ un nõ di schū, nō hot mer mē glik. $(B u, C, L n c, S n, Y$; Heidelberg)

It is luckier to put on both stockings first and then the shoes.

466. Wąmmern schpel uf em bodem leie sēnt mit em kopp gēğich em bedeits glik. ( $B e, C, L n c, M r, N a, S n, Y)$ It is a good omen to see a pin lying on the floor with the head towards you.

Wenn man eine nadel findet, die einem die kappe zukehrt, wird man glück haben. $G R 424$

It is unlucky to find a pin with the point toward you. $V$ $S L 2.178$

467. Wạnn en schpel uf em bodem leit un mer sēnt sie mit em kopp gēğich em hot mer unglik. ( $L b, L n c, S c$, Sn; Heidelberg)

A pin on the floor with the head towards you means bad luck.

468. Mer kērts glik naus wạmmer di kich fer sunnufgąng kērt. (Lb; Heidelberg)

You will sweep out your luck if you sweep out the kitchen before sunrise.

469. Di kich soll mer net noch sunnunnergang auskēre, mer kērts glik naus. ( $B e, C, D, L b, L h, L n c, N u, S c, S n$, $Y$; Heidelberg)

Never sweep the kitchen after sunset, you will sweep out your luck.

Never sweep out your kitehen after sunset or you will sweep out your luck. $C S A 651$

470. Noch de fir ūr oder wann di sunn unner is kērt mers haus net aus oder mer kërts glik naus. (Lh)

The house must not be swept after 4 P. M., or after sunset, or you will sweep out your luck.

470. Nạchts es haus auskēre bringt unglik. $(Y)$

Sweeping the house at night brings bad luck. 
472. Mer dærf ken kērdrek zu der dìr nauskēre, mer kērts glik wek. $(A f)$

You must not sweep the dirt out of your house, you will sweep away good forutne.

Man kehrt ihn herein, nicht hinaus. Hlbg.

It is ill luck to sweep the dust out of your house by the front door. You sweep away good fortune of your family. It must be swept inwards and carried out in a basket or shovel and no harm will follow. $V S L 2.176$

473. Wǣr glik hot mit kårte hot gewēnlich kens mit de weibsleit. (C, D, Lh, Lnc, Sc,Sn)

Lucky at cards, unlucky in love.

Wer glück im spiel hat, hat unglück in der liebe. $B S$ 33. 198

Lucky at cards, unlucky in love. $V S L 2.80$

474. Wannd en schpiğel ferbrechscht, hoscht ken glik mē. $(A f)$

Your luck is gone if you break a mirror.

475. Wạmmer ærğets hĩ gēt uns schpringt em en hås iber der wēk, gengt mer besser zurik oders dèt em en unglik wederfåre. $(\dot{D}, L b, L h, N a, S c, Y)$

If a rabbit crosses your path when going on a journey, you had better return or an acident will befall you.

Wer verreist, und es läuft ihm ein hase über den weg, das ist nicht gut. $G 3.10 ; C P \& P 477$

476. Wammern fïr blettrich glēblåt finnt, soll mers åbroppe un esse fer glik. $(Y)$

If you find a four leaved clover, pluck it and eat it for luck.

477. Wạmmern fitr blettrich glēblåt finnt soll mers net ąbroppe, schunscht ferhaust mer sei ${ }^{\sim}$ glik. $(B e, C, D$, $L b, L h, L n c, S c)$

If you find a four leaved clover, don't pluck it, or you will spoil your luck. 
478. Wạnn zwẽ leit minnạnner låfe dærf nimañd gschwischich ne dærichlåfe schunscht hot kens ken glik. $(A f)$

When two persons are walking together, nothing must come in between them, or it will spoil the luck of both.

Wenn man nit einer zweiten person auf einem geschäftsoder spazierwege begriffen ist, darf man keine dritte person zwischen sich durch lassen; dieselbe nimmt beiden ersten sonst das glück mit. $B S 33.139$

tiy. Dærich en schpinnewēb låfe bringt güt glik. ( $L h$, Lnc, Na, Sc)

Walking through a spiderweb brings good luck.

Wem frühmorgens eine spinne über den rock kriecht, der wird des tages glückselig sein. $R$ G 208

450. Sibe jōr hot mer ken glik wạmmern schpiğel ferbrecht. (Be, Lb, Lnc, Y; Heidelberg)

Breaking a looking glass forebodes seven years of ill luck.

Breaking a looking glass means seven years of trouble or sorrow. $V S L 2.184$; C S A 710

481. En schpiğel ferbreche bedeit en unglik. (Af; Heidelberg)

It is unlucky to break a mirror.

It is unlucky to break a looking glass. V S L 2.184

482. Wạnn en alti frå zu em gelofe kummt mēnts en un= glik. $(L n c)$

Meeting an old woman is a bad omen.

Es ist nicht gut, wer morgens ausgeht, und es begegnet ihm ein alt weib. $G 3.58$

For a sportsman to met an old woman when going out shooting is a sure sign of bad sport. V $S L 2.201$

483. Wạmmer bærik nuf fallt bedeits glik. (Be, $B u, C, L b$, $L h, L n c, M t, N a, S c)$

Falling up hill brings luck.

484. W̄̄r en fïrblettrich glēblåt nōdråkt hot glik. ( $B u, C$, $D, L b, L h, L n c, M t, N u, S c, S n, Y$ ) 
Carry a four leaved clover for luck.

Wer vierblättrigen klee findet, soll ihn wert halten; so lang er ihn hat, wird er glückselig sein. G 3.119

The possessor of the four leaved shamrock will have luck in gambling, luck in racing, and witcheraft will have no power over him. Ir 2.103

485. Grōsse schwarze schlannge sēne bringt schlecht glik. $(B e)$

Seeing big blacksnakes brings bad luck.

486. Wạmmer fische gēt un 's låft em en weibsmensch ib̄er der wēk fangt mer ken fisch seller dåk. $(C, M t)$ If a woman crosses your path when going fishing you won't catch any fish.

487. Wạmmer sich ebbes å̃ nēe oder flike losst wạmmers $a^{\sim}$ hot, grikt mern feind. $(N u)$

If you let anyone sew or mend anything when you have it on, you will get an enemy.

488. Wạmmer sich ebbes å̃ nēe oder flike losst wămmers $\AA^{\sim}$ hot, nēt mer schmærze å fer jēder schtich. $(C, S c)$ If you let anyone sew or mend anything while you have it on you will sew on a pain with each stitch.

489. Mer soll nímand nix å̃ nēe losse wạmmers å hot oders likkt ebber wëich em. (Lb,Lnc, Sc)

If you let anybody sew anything while you have it on, - some one will lie about you.

490. Mer soll nìmand nix å̃ nēe oder mer nēt em drubel $\AA^{2}$. $(C, L n c)$

Never sew anything on for any one or you will sew trouble on.

491. Mer soll ntmạnd nix å nēe oder mer nēt em di gidankke fescht. $(L b, S c)$

Never let anyone sew anything while you have it on, or he will sew your thoughts in. 
492. Wạmmer ebber em ebbes å nēe losst wạmmers å hot, nēts em 's glik wek. ( $B e, L b, L h, S c)$

If anyone sews anything while you have it on, he will sew your good luck away.

493. Mer soll nimand nix å̃nēe wanners å hot oder mer nēt drubel $\AA^{\sim}$. $(B e, C, D, L h, L n c)$

If anyone sews or mends anything while you have it on, he will sew trouble on.

494. Mer soll nimand nix å̃nēe losse wammers å hot oder mer wært dumm. (Be, Bu, D, Lb, Lh, Na, Nu, Sn) If one has anything sewed or mended while he has it on, he will become a simpleton.

Wer sich das zeug am leibe flicken, einen knopf oder band annähen lässt, verliert das gedächtnis, seine kraft oder verunreinigt sich noch im tode. $B S 33.181$

495. Wạnn en schtærn fallt un mer sēnts iber di links axxel bedeits schlecht glik.

Seeing a meteor over one's left shoulder means bad luck.

496. Wạmmer der neimūnd 's ërschtmol iber di links axel sēnt un hot geld in der hand, grikt mer mē. ( $L b, Y$; Freiburg)

If, when you see the new moon for the first time over your left shoulder, you have money in your hand, you will get more money. 


\section{OMENS OF DEATH}

497. Wạn em di leine in der hạnd zạmmerlåfe lëbt mer net lang. (Lnc)

If the lines in the palm of your hand run together, you will not live long.

Wenn die falten in der hand zusammenlaufen, lebt man nicht lange. $\quad Z 189$

498. Wạnn in der kærich gebēt wært fern grạnkes uns is alles schtill, schtærbts. (Lh)

If there is perfect silence in church while prayers are being offered for a sick person, he will die.

Herrscht beim krankengebet in der kirche völlige stille, so stirbt der kranke; liustet einer oder rauseht etwas, so bleibt er leben. $G 3.490$

499. Wanns windschtill is uf Neijōr schtærbe fill allte leit. (Be, Lb, Lh, $\mathrm{Mr}, \mathrm{Nu}, \mathrm{Sc}$; Heidelberg)

If it is perfectly calm on New Year's, many old folks will die.

500. Wann en schtærn ufs haus fallt gēt ēns naus. ( $B$ s, $S c)$

If a meteor falls on a house, some one there will die.

Ein haus, bei welchem ein stern niederfällt, darin wird nächstens einer sterben. $G 3.1115$

501. Wammer middåks frisch brōt uf em disch hot un di uir schlakt 12 wammer am disch hokt, schtærbt èns aus der fạmilie. ( $D, L b, L h, L n c, M t, Y)$

If the elock strikes twelve when taking dinner at which fresh bread is served, some one will die in the family.

502. Wạnn di geil greische schtærø̄e fíl leit. ( $B u, L b, L n c$, $M t, Y)$

If horses neigh there will be many deaths.

Wenn die pferde ungewöhnlich stark wiehern, so bedeutet es krieg. $\quad W u 199$ 
503. Wǣr en weissi schpinn sēnt schtærbt. $(\mathrm{Na})$

He who sees a white spider will die.

......Wenn's eine kreuzspinne ist. Hlbg.

504. Wanns hausrōt grext gebts en unglik in der freindschąft oders schtærbt ēns. (Bu,D,Lb,Lh,Lnc, $\mathrm{Nu}, \mathrm{Sn}, \mathrm{Y}$ )

Creaking furniture is an omen of death or misfortune among your relatives.

Es stirbt jemand im hause, wenn dielen, schränke, tische usw krachen. $W u 212$

505. Wạnn di hinkel ōbeds gaxe gebts en leicht. ( $A f)$

The caekling of hens in the evening is an omen of death.

Wenn die hühner nachmittags nach der melkzeit gackern, so muss bald jemand im hause sterben. Wu 202

506. Wạnn en hinkel grēt bedeits en leicht. (Af)

A crowing hen is a sign of a death.

Krähende hennen bedeuten unglück. $G 3.83$

507. Es schtærbt ēns aus der freindschaft wạn di hinkel mærğets frì gaxe. (Be,C,D,Lh, Na; Kaiserslautern)

A relative will die if the hens cackle early in the morning.

508. Wạnn di hinkel mærğets frì gạxe gebts en leicht; ōbeds schpōt, en hochzich. (Lnc, Y; Freiburg)

Cackling of hens early in the morning presages a death; late at night, a wedding.

509. Wạnn en schmēsmik ins haus flikt hērt mer fun re leicht. ( $B u, L h, L n c, N a)$

If a blowfly enters your house you will hear of a death.

510. Wann grautschtek 's èrscht jōr schîsse gebts en leicht. (Mr; Heidelberg)

Cabbage plants running to seed the first year are an omen of deatl.

511. Wạnn rōtrtbe 's ērscht jōr schîsse un sūme grtğe bedeits en leicht. ( $C$; Heidelberg)

If beets run to seed the first year it presages a funeral. 
512. Wạnn die ūr zwelfe schląkt wạmmer ąm disch is, gebts en leicht oder bsuch. $(B e, B u, D, L b, L h, M t, N a$, $S n)$

A clock striking twelve while taking dinner presages a death in the family or visitors.

513. Wạmmer fergesst dēl fum sạch in der ofe zu dũ wạmmer am bake is schtærbt en ganz nēkschter freind. $(L b, L h, M r, S n, Y)$

A very near relative will die if you forget to put in the oven all the articles you intended to bake.

514. Wạmmern schpiğel ferbrecht gebts en leicht. (Af) Breaking a mirror is an omen of death.

515. Wanns brōt iberm bake in der mitt ufschpringt bedeits en leicht. ( $B e, B u, C, D, L b, L h, L n c, M t, S c, S n$, $Y$; Kaiserslautern)

If the crust of a loaf of bread cracks across the middle it forebodes a death in the family.

516. Wạnn di brōtgruscht lōsschpringt iøerm bąke schtærbt èns aus der fạmilie. $(A f)$

If the crust separates from the loaf of bread while baking. it is an omen of death in the family.

517. W̄̄r Sunndåks grank wart schtēt nimmi uf. (Be, $B u, C, D, L b, L h, L n c, N a, N u, S c, Y$ )

If you fall sick on Sunday you will not get well.

Wenn man am Sonntage krank wird, muss man sterben. $W u 59$

518. Wạn en dischmesser eநerschich uf em disch leit, gebts en leicht. $(B e)$

A table knife lying on the table with the edge upward forebodes a death.

519. Wąnn em sei schątte ken kopp hot der obed fer neijōr, muss mer inner me jōr schtærøe. (D)

If your shadow is headless on New Year's eve, you will die within a year. 
Weihnachtsabends, wessen schatten bei eingebrachtem licht keinen kopf hat, der stirbt in selbigem jahr. $G$ 3. 55

520. Wănn en hund unich em fenschter heilt bedeits en leicht. $(\mathrm{Be}, \mathrm{Mr}, \mathrm{Nu}, \mathrm{Y})$

The whining of a dog beneath a window is an omen of death.

If a dog is heard to howl near the house of a sick person all hope of his recovery is given up. $\operatorname{Ir} 2.2$

521. Wạnn di geil unrüich sinn gebts en' leicht. $(B e, C$, $D, L b, L n c, M r, M t, N a, S c, S n, Y$; Heidelberg)

If horses are restless it is an omen of death.

522. Es schtærbt ēns aus der familie wanmer en loch in di ditr macht oder ausre wand reist fern fenschter nei zu mache. (Lnc, Mr, Na; Freiburg)

There will be a death in the family if a window is put into a door or wall of the house.

To rebuild a house is always fatal to one member of the family. $D Y 54$

523. Wămmer fergesst en lēb brōt aus em ofe zu nemme, schtærbt ēns. (Lb, Lnc, Sn)

Forgetting to take a loaf of bread out of the oven will cause a death.

If you overturn a loaf of bread in the oven, you will have a death in the house. $C F$ Suf 1.30

524. Wann en grankes es maul im bett ufschpærrt is es en schlechti sein. (Bu,Lb,Lh,Lnc, Mr, Nu,Sn, Y; Heidelberg)

Yawning while sick in bed is a bad omen.

525. Wămmern lēri wîk schokelt, schtærbts kind băll. $(L n c)$

Rock an empty cradle and the child will not live long.

Wird eine leere wiege geschaukelt, stirbt das sonst darin liegende kind bald. $Z 24$

Rocking a child's empty cradle will kill the child. $H N C$ 18; CS A 49 
526. Wămmern schpiğel ferbrecht gebts en leicht. (Be, $B u, C, D, L b, L h, L n c, N a, N u, S s, Y$ )

To break a looking glass is a sign of death in the family before the year closes. $C S A 1204$

When a mirror breaks it presages a death. $E Y 42$

527. Wann en piktscher fun der wănd fallt bedeits en leicht. (Af)

A picture falling from the wall is an omen of death.

Wenn ein bild von der wand fällt, bedeutet dies unglück. $Z 249$

When pictures fall from the wall it forebodes a death in the family. $E Y 42$

528. Wann en hinkel grēt gebts en leicht. (Af)

If a hen crows there will be a funeral.

Krähende hennen bedeuten unglück. $G 3.83$

The crowing of the hen foretells death. $V S L 2.550$

529. Wann en hund heilt gebts en leicht. ( $A f)$

When a dog howls there will be a funeral.

Wenn ein hund vor einem hause heult, so zeigt dies den nahen tod eines bewohners desselben an. $Z$ f $D M 1.408$

If a dog howls three successive nights against a house, that house will soon be in mourning. $V S L 2.550$

530. Wạnn di håne fîl grēe gebts en leicht. $(B u)$

The continual crowing of cocks indicates a funeral.

Young eocks crowing at night are a death warning. $V S$ $L$ 2. 550

531. Wạnn en grixl sich ins haus schạfft bedeits en leicht. $(B e, D, L h, S c, Y)$

If a cricket gets into a house, there will be a death.

Das zirpen der grillen im hause bedeutet einen nahen todesfall in der familie. $B S 33.119 ; Z f D M 1.236 ; C P$ \& P 519

The chirping of crickets foretells of death. $V S L 2.550$

532. Wạnn di ūr uf ëmol schtē $\widetilde{-}$ bleibt gebts en unglik odern leicht. (Af) 
If the clock stops suddenly there will be an accident or a death.

Wenn die uhr plötzlich stehen bleibt, so geschieht ein unglück, meistens ein todesfall. $V A S 1$. 474; $M S V 268$

533. Wạnn en grankes am bettsach zoppt schtærbs ba्nll. $(B e, B u, C, L b, L h, M t, N a, N u, Y$ )

If a sick person pulls at the bedelothes he will soon die.

Wenn ein kranker an der bettdecke pflückt, stirbt er bald. $Z 410$

Picking the bedclothes forebodes impending dissolution. $V S L 2.573$

534. Wạmmern grạb uf der schtrōs å drefft, mēnts en leicht. $(L h)$

Meeting a crow on the street is the sign of a funeral.

When a single crow flies over you, it is the sign of a funeral ; two, of a wedding. $V S L 2.1 .335$

535. Grine Grischdåk, fetter kærichhōf. (Af)

Green Christmas, means a fat churchyard.

A green Yule means a fat kirkyard. $V S L 2.1 .215$

536. Wammer fergesst en fruchtschēmel zu sēe, schtærbt mer sell jōr. $(B e, L b, L h, L n c, S c, S n, Y)$

If, while sowing grain, you miss a strip, you will die within a year.

If the drill go from one end of the field to the other without depositing any seed, some one on the farm will die. $V S L 2.570$

When sowing grain, if a strip of land is missed there will be a death inside of a year. $C S A 1228$

537. Wạmmer ferfëlt en roi zu blanze im gårde, schtærbt mer sell jōr $(B e, D, L b, L n c, N a, S c, S n)$; oder wammer ferfēlt in $\bar{e}^{\sim}$ loch ebbes zu blanze. $(B e, D, L b$, $L n c, N u, S n, Y$ )

If while planting vegetables in the garden, you miss a row or even a single hole, you will die that year.

Vergisst der säemann ein ackerbeet zu säen, so muss er sterben. $M D V 223$ 
538. Wạnn en schpiğel ferbrecht iちerm zìğe schtærbt èns. ( $B e, B u, L b, L n c, S c, Y)$ oders gebt en unglik. ( $M t$, $\mathrm{Na} ; \mathrm{Freiburg})$

If a mirror breaks when moving some one will die or there will be an accident.

539. Wammer dråmt es wǣr em en zå rausgfâlle, schtærbt ebber in der freindschaft $(B e, B u, C, D, L h, L n c$, $M t, N a, N u, S n)$ oder em sei ${ }^{\sim}$ beschter freind $(N u$, $S c, Y$; Heidelberg)

To dream of losing a tooth means the death of a relative or one's best friend.

To dream of losing a friend means a death. $V S L 2.552$; $C S A 549$

If a man dream that his teeth fall out, he will hear next day of the death of a friend or relative. V S 2.299

540. Wạnn en kind heilt wạnns gedåft wært, schtærbts jung. (Lh)

If a child cries while being baptized, it will die young.

Wenn das kind bei der taufe schreit, wird es nicht alt. $W u 222$

541. Wạnn en fōğel ins haus flikt mēnts ås bạll ēns schtærbt oders gebt en unglik. ( $A f)$

A bird flying into the house is an omen of death or ill luck. When a bird flies into a room and out again it forebodes the death of some inmate. $V S L 2.557$

542. Wann en grautschtok odern rōtriteschtok 's ærscht jōr schîsst, schtærbt ēns aus der fămilie. $(B e, C, D$, $\mathrm{Lb}, \mathrm{Lh}, \mathrm{Lnc}, \mathrm{Mr}, \mathrm{Mt}, \mathrm{Na}, \mathrm{Nu}$ )

If cabbage or a beet (Beta vulgaris) shoots the first year, some one in the family will die.

Wenn eine kohlpflanze im ersten jahr blüte trägt, bedeutet es tod. $W 207 ; G 3.1114$

543. Wann dreizẽ ${ }^{\sim}$ agm disch hoke, schtærbt ëns defun innerme jōr. $(A f)$

If thirteen sit down to a meal, one of them will die within a year. 
Wenn bei einer festlichkeit zufällig dreizehn personen an einem tische speisen, stirbt einer von ihnen im laufe des jahres. $B S 33.119 ; G 3.555 ; Z 255 ; C P \& P 277$; $V S L 2.560$

544. Wạnn en grautschtok es ērscht jōr weisse blätter grikt bedeits en leicht. ( $B e, C, L b, M r, N a, N u, S c, S n, Y$ ) If a cabbage plant has white leaves, it means a funeral. Wenn eine kohlpflanze im ersten jahr weisse stellen an den blättern bekommt, entsteht in dem hause des besitzers ein unglücksfall. $G$ 3. 1114

If in a row of beans one should come up white instead of green, it means a death in the family within the year. $V S L 2.570$

545. Es dærf kēe ungrådi nummer an der disch gēe , schunscht schtærbt ēns. ( $B u, D, L b, L n c, N a, S n)$

The number of persons sitting down to a meal must never be odd, else one will die.

546. En grautschtok 's ǣrscht jōr sūme gríğe mēnt en leicht. ( $B e, C, D, L h, L n c, M r, M t, N a, N u, S n, Y)$ If a cabbage goes to seed the first year, it portends a death. Wenn eine kohlpflanze im ersten jahr weisse stellen an den in dem hause des besitzers ein unglücksfall. $G 3.1114$

547. Wạn di geil greische an re leicht schtærbt glei wider ēns. (Af; Heidelberg)

Neighing of horses at a funeral indicates another death.

A horse neighing at your door betokens coming grief. $V$ $S L$ 2. 1. 327

548. Wạnn ōbschtbēm schpōtjōrs blìe, schtærbt ēns in der fạmilie. $(A f)$

The blossoming of fruit trees in fall is a sign of death.

Wenn ein apfel- oder birnbaum im herbst blüht, gibt es eine leiche, bes. des hausherrn. $W u 207$

The flowering of a tree twice in the same year is a death omen. $V S L 2.558$ 
549. Wạnn en kind di éberschte zẽ ${ }^{\sim}$ 's erscht grikt, lēbts net lanng. ( $B e, B u, D, L b, L h, L n c, S c, S n, Y)$ If a child cuts the upper teeth first it will not live long. Wenn ein kind die zwei vorderen zähnchen zuerst oben kriegt, dann zahnt das kind unter dem boden, d. h. es stirbt unter dem zahnen. Alem 27. 229; Wu 217 If an infant cut its front tooth in the upper gums, it would be shortlived. $G S \operatorname{scot} 48$

550. Wạnn en dōdes en åk uf hot, mēnts ạs glei wider ēns schtærbt uns gukt ebs glei nōkummt. ( $A f)$

If the eye or eyes of a corpse remain unclosed, there will be another death, for it is looking for the next one to follow.

Wenn dem verstorbenen trotz alles zudrücken die augen offen stehen bleiben, stirbt bald einer aus der familie nach. $B S 33.119 ; Z f D M 4.148 ; M D V 270 ; Z 424$ If the eyes of a corpse are difficult to close it is said they are looking after a follower. $V S L 2.571$

551. Wạnn ēns iøler wært Sunndåks gēts dōd. (Bu, Lnc, $M t, N u$; Heidelberg)

If a person becomes worse on Sunday he will die.

552. Wạnn di granket sich Sunndåks wekselt is es en schlechti sein. (Be, Bu, D, Lnc, Mt, $Y$; Heidelberg) If a sick person becomes worse on Sunday it is a bad sign.

553. Wannen grankes Sunndåks besser is, is es en schlechti sein as es driber kummt; wanns Sunndåks ą̋er schlimmer is, is es besser di woch druf. $(B e, B u$, $M t, S n, Y$ )

Improvement in the condition of a sick person on Sunday is a bad sign; but if the patient is worse he will be better the ensuing week.

Wenn sich der kranke am Sonntag beser fühlt als an den andern tagen, so stirbt er. $W u 221$

In Scotland illness was expected to be more severe on Sunday than on any other day; and a relapse was anticipated if the patient felt easier. $B$ F 133 
554. En nei hemm muss mer wesche eb mers å dut, schunscht wammer grạk drin wært wært mer nimmi gsund. (Sc, $Y$; Heidelberg)

A new shirt must be washed before it is worn, for in case you are taken sick in an unwashed shirt, you will never get well.

555. Wammern nei glèd å dut un wært grank drin wært mer nimmi gsund. (Be, $D, L h, N a, S c, S n, Y)$

If you are taken sick while wearing a new article of clothing for the first time, you will never get well.

556. Wạnn di ūr zwelfe schląkt wạnmer ạm disch ạm bēte is færm esse, gebts en leicht. ( $L n c)$

If a clock strikes twelve while saying grace there will be a funeral.

Wenn die turmuhr während des läutens zum gebet schlägt, so stirbt bald jemand aus der Gemeinde. Wu 215

557. Wạnn der bakofe singt schtrarbt ēns. (Be, Bu, Mt; Heidelberg)

If the bake oven sings it is an omen of death.

558. Wạnn ebbes ferbrecht ạs ganz wår uns wår nłmand um de wēk, gebts en leicht in sellem haus. ( $A f)$

If anything breaks without being touched or handled, it means a funeral.

Wenn ein trinkglas oder eine fensterscheibe von selbst zerspringt, stirbt jemand im hause. $W u 212$

559. Wạnns dunnert in der dærre wald

Schtærbt jung un alt. (Be, Lb, Mt, Sc, Sn)

If it thunders when the woods are bare, both old and young will die.

Wann's dunnert üwwern dörre wald,

Geht's üwwer jung und alt. Alem 20. 286

560. Wạnn di kinner allzamme unferhofft hēm kumme, kumme si 's nēkscht mol hēm an en leicht. ( $B e, C$, $D, L b, L n c, M r, M t, Y$; Freiburg)

If all the children come home unexpectedly, they will come home next time to a funeral. 
561. Wū der wipperwill nēkscht greischt gebts en leicht. $(B e, D, L b, L h, N a, Y)$

The call of the whipporwill nearby is an omen of death.

Der ruf der eule bedeutet nahen todesfall in der familie. B $S$ 33. 119

562. Wanns windschtill is uf der Unschuldich Kindelsdåk schtærbe fìl kinner 's nēkscht jōr. (Be, Lh)

If the weather is calm on Innocents' day (Dec. 28), many children will die the following year.

Am tage "der unschuldigen kindlein (28. Dez.) bedeuten lämmerwolken, schäfchen, für wochnerinnen ein unglückliches jahr, und es werden bes. viel knaben sterben. Wu 197

564. Wạmmer Sunndåks grank wært wært mer nimmi gsund. (Be, Lnc, Sc; Heidelberg)

If you are taken sick on Sunday your sickness will be fatal.

563. Wanns gewittre gebt uf der Himmelferdåk schtærbe fîl im kindbett. (Bu,C,Lb,Lh,Lnc, Sc)

Many women will die in confinement if there are thunderstorms on Ascension Day.

565. Wannd grank bischt un si muke dich aus ënre schtub in di anner, wærscht nimmi gsund. (Be,Lnc, $S c$; Heidelberg)

Change a sick person from one room to another and he will die.

566. Wạnns jingscht oders eltscht ąm disch ntst hērt mer fun re leicht. (Be, Bu,C,Lh, $\mathrm{Na}, S c, Y$; Kaiserslautern)

If the youngest or oldest sneeze at the table you will hear of a funeral.

567. Wạn ēns mærğets anm disch ntst, hert mer fun re leicht. $(S n)$

Sneeze at the breakfast table and you will hear of a funeral.

568. Wann ēns ạm disch ntst hërt mer fun re leicht. ( $B e$, $B u, L b, L h, M t, N a, S c)$

Sneezing at the table is a sign of death. 
569. Wạmmer zwible blanzzt un ferfēlt en roi schtærbt ēns. $(B e, D, L n c, S n)$

If you miss a row in planting onions, some one will die.

570. Wạnns nix wi glēne gummere ạn di schtek gebt, gebts en leicht. $(M r)$

If cucumbers bear only small fruit, it forbodes a funeral.

571. Wammer der Quatember Mittwoch wescht un wært grank wært mer nimmi gsund. ( $L b$; Heidelberg) If you wash on the Wednesday nearest an Emberday and are taken sick, you will never get well.

572. Wạnn di eile nēkscht ăm haus greische gebts en leicht. $(L b)$ The hooting of owls near a house is an omen of death. 


\section{DEATH OMENS CONCERNING DEATH}

573. Wănn ēns fun de drēğer schtolpert gebts noch en leicht. $(B u, M t)$

The stumbling of a pallbearer is an omen of another funeral.

574. Wạnn di drēğer ạs en dōdes dråğe færme haus schtoppe, schtærbt ēns aus sellem haus. ( $B e, L b$, $Y$ )

If pallbearers stop in front of a house, some one in that house will soon die.

Wenn ein leichenzug vor dem hause stehen bleibt, stirbt jemand im hause. $W u 213$

575. Wanns in en gråb reğert schtærbt noch en nēkschter freind. $(D, L n c, Y)$

If it rains into an open grave a near relative will die.

Wenn es in ein neues grab regnet, so stirbt bald wieder jemand. $W u 197$

576. Wann en dōdewăğe schtopt uf em wēk gebts noch en leicht. ( $B e, B u, C, L b, L h, L n c, M r, N a, S c, S n)$ If a hearse stops on the way to the cemetery or church, another funeral may be expected.

Der leichenwagen darf unterwegs nirgends stehen bleiben. $W u 466$

577. Wann en gråb ei fạllt gebts băll wider en leicht. (Be, $C, D, L n c, M r, N u, S c, Y$ )

If a grave caves in there will soon be another funeral.

Wenn ein grab einsinkt, kommt bald eine leiche. $Z 409$

578. Wannn en leicht ferbei is uf em kærichhōf uns gēt en weibsmensch 's ērscht fum kærichhōf is es nēkscht as schtærbt wider en weibsmensch; wann en mannskærl, en mannnskærl. (Be,Lh, Lnc, Mr; Heidelberg) The sex of the first person to leave the cemetery after the funeral forebodes the sex of the next person to die. 
If the first person a funeral procession meets on taking a corpse to the church for interment is a male, a female is sure to be the next who dies in the village, and vice versa. Den 2. 49

579. Wạnn di leit ærik schtærik låfe oder fåre ạn re leicht gebts glei wider ēni. ( $B u, D, L n c, M t)$

There will soon be another death if the funeral procession moves very rapidly.

Wenn die pferde am leichenwagen stehen bleiben oder zu rasch eilen, so folgt noch eine leiche. $W u 199$

If when the funeral left the house, the company walked very quickly, it was a bad omen. N Scot 63

580. Wănn en nēkschter freind zu schpōt an en leicht kummt gebts glei wider ēni. ( $B e, B u, C, D, L b, L h$, $\mathrm{Na}$; Heidelberg)

If a near relative is late at a funeral, it is an omen that there will soon be another death.

If any one comes to the funeral after the procession starts, another death will occur in the same house. $C S A 1192$

581. Wạnn di leicht ferzottelt fum haus færtgēt gebts glei wider ēni. $(B u, C)$

If the funeral procession leaves the house in a scattered, straggling manner, there will soon be another funeral.

If, when a funeral left the house the company should go in a scattered straggling manner, this was an omen that before long another funeral would leave the same house. $N S \cot 63$

582. Wạnn ēns schtærbt un wært net gråd kạlt un schteif, schtærbt glei wider ēns. $(B e, B u, C, L h, L n c, M t$, $\mathrm{Na}$ )

If a corpse does not become cold and rigid immediately after death, there will soon be another death in the fam. ily.

Wird ein leichnam nicht bald kalt und starr, so holt er binnen jahresfrist ein weiteres familienglied. $V A S$ 1. $476 ; G 3.368 ; M D V 272$ 
If the neck of a dead child remains flexible for several hours after its decease, it portends that some person in that house will die in a short time. $V S L 2.571$

583. Wạnn en dōdes in der kærich oder uf em kærichhōf mit em kopp gēğe hēm leit, schtærbt wider ēns. $(B e)$ If the body of the deceased in church or on cemetery faces its home, there will soon be another funeral.

Dass der verstorbene nicht mehr kommt, so trägt man ihn mit dem kopf zuerst aus dem haus. A $S 1.396$

The custom of placing the corpse with the feet toward the door has descended from early times. $V S L 2.584$

584. Wạnn der kærichhōf uf is gschwische Grischdåk un Neijōr gebts fîl leichte sell jōr. $(B e, C, D, L h, L n c$, $M r, M t, N a, S c, Y$ )

If there are any funerals between Christmas and New $Y$ ear, there will be many funerals in that congregation the following year.

Begräbnisse in der zeit der zwölfnächte bedeuten viele todesfälle. $W u 63$

A death in Christmastide betokens many more. $V S L$ 2. 1.234

585. Wạnns so ferhudelt hǣrgēt ạn re leicht, gebts glei wider ēni. (Af)

If everything is in confusion at a funeral there will soon be another one.

586. Wạns singe so schlecht gēt an re leicht gebts glei wider ēni. (Bu, Lh, Mt, Na,Sn)

If singing at a funeral is wretched there will soon be another funeral.

Wenn der gesang beim aussingen einer leiche sehr hell und weit klingt, so stirbt gleich wieder jemand. $K n p .164$

587. Mer dærf en leicht net schtoppe oders gēt glei ēns nō. (Af; Heidelberg)

A funeral procession must not halt or another death will soon follow. 


\section{SUPERSTITIONS CONNECTED WITH DEATH}

588. Mer dǣrf net zēle wi fíl fūre ann re leicht sin. (Be, $L b$, $L h, L n c, M t, N a, N u)$

Never count the number of vehicles in a funeral procession. ......es bedeutet unglück. Hlbg.

589. En dōdes begråbt mer net mit rings un so weiter å . $(B e, C, D, L n c, S c)$

All jewelry should be taken from the corpse before burial. Dem verstorbenen soll man alle ringe usw. abnehmen, sonst kann er nicht selig werden. $Z 432$

590. Wạmmern ǣrdlichtel sēnt bedeits as en mannn gschtærbe is un zurikkumme is un seine leinfense nōgukt. (Be, $C, D, L b, L h, L n c, M r, M t, S n$ )

An ignis fatuus is the spirit of the deceased who has returned to earth to look after his line fences.

Irrlichter sind die seelen solcher, die grenzsteine verrückt haben. $W u 478,475$

591. Wạnn fîl kinner nạnner nō aus re fạmilie schtærbe, soll mer guke ebs êrscht a as gschtærbe is net ferleicht ebbes fun de dōdeglēder ins maul gzoğe hot. $(B e$, $D, L h, M r, S c, S n)$

If there are many deaths in a family in rapid succession, the grave of the first of those to die should be opened, to see whether the corpse has not drawn a part of its shroud into its mouth.

Der tote muss so angekleidet werden, dass er nichts von seiner kleidung in den mund bekommen kann, sonst zieht er bald einen nahen verwandten durch den tod zu sich. B S p. 120

592. Wạnn ēns schtærbt, gēt alles wạs es gblanzt hot nōch un nōch dōt. $(B u, L h, L n c, M t)$

Everything planted by a person before his death will gradually die. 
Stirbt der säemann in Westfalen im laufe des jahres, so gedeit die von ihm gesäete frucht nicht mehr. $M D V 224$

593. Wǣr sich færcht soll en dōdes år rēğe. (Be,C, $D, L b$, $L h, M r, N a, N u, S c, Y$ )

A fearful person should touch a corpse.

Wer grosse ängsten hat, rühr an die grosse zehe eines toten, so wird er frei davon. $G 3.544$

594. Wann di leicht âm haus færtgēt muss mer di ìme rike oder si gēne dōd $(S c)$ oder si sin nix mē wǣrt. (Be, $L b, L h)$

Move the bee hive when the funeral leaves the house to prevent the bees from dying or becoming worthless.

Stirbt jemand im hause, soll man die bienenkörbe rücken, sonst stehen die bienen ab. $G 3.576$

On the death of a relative the bees are acquainted of the event by moving the hive. $S \& C S 9$

595. Mer muss ken gråbschtē $\overline{-}^{\sim}$ fern dōdes uf dū $\sim$ eb en jōr ferbei is, schunscht schtærbt wider ēns. ( $B e, B u, L b$, At least a year should elapse before a tombstone is erected to the memory of the deceased, else there will be another funeral in the family.

...... Dann kommt noch eins auf die welt und es stirbt noch eins. Hlbg.

596. Wạmmern glid a abnemme losst un mer hot noch ærğe schmærze im schtumbe, is ferleicht 's abgenumme dēl net gråd im gråb. ( $B e, B u, D, L h, N u, S c, S n, Y)$

If you have great pain after an amputation, the amputated member is probably not buried straight.

Wenn man einen fuss abnehmen muss, so muss man ihn aufrecht begraben, sonst tut er immer noch weh. $V A S$ 1. 486

597. Mer soll sich di grēåğe ăbschneide mit me dōde seim balbírmesser. $\quad(B e, C, D, L b, L h, L n c, M t, N u, S n$, Y; Freiburg)

Cut your corns with a dead man's razor. 
598. Wămmer sich bạltitrt mit me dōde mann seim ballbtrmesser, grikt mern weisser bårt. (Bu; Heidelberg) If you shave with a dead man's razor, your beard will turn prematurely gray.

599. Mer ferlitrt der giruch wammer an blume rìcht ås uf me gråb waxxe oder uf re låd geleğe hen. (Bu,Lh, Lnc, Sn, Y)

Smelling at flowers which grow on a grave or have lain on a coffin will destroy the sense of smell.

An blumen oder kränzen, die auf dem sarge des toten oder auf seinem grabhügel liegen, darf man nicht riechen, sonst verliert man den geruch. $B S 33.120$

600. Blumeschtek dærf mer keni aus em kærichhōf hēmhōle un blanzze, es schtærbt ēns aus der fąmilie. (Be,C, $D, L n c, M r, N a, N u, S n, Y$; Heidelberg)

Some member of the family will die if flowers which grew in a cemetery are brought home and planted.

601. Wănn ēns im haus schtærbt, misse di blumeschtek rumgschtellt wærre. $(B u, C, L n c, M r, N a)$

Potted plants should be rearranged immediately after a death in the family.

Nach einem todesfall soll man blumentöpfe verstellen, die pflanzen sterben sonst ab. Alem 6. 174

602. Wannd en gicht'rōseschtok wek'gebscht schtærbt ēns aus der fami'lie in'nerme jōr. (Be,C,D,Lh, Lnc, Mt; Heidelberg)

If you present some one with a peony plant (Paeonia officinalis), some one of your family will die within a year.

603. Wann ëns zurik'gukt an re leicht schtærbt glei wider èns. ( $B e, B u, L b, L n c, M r, N a, S c, S n)$

If any one in a funeral procession looks back there will soon be another funeral.

Bei dem leichenzuge darf keiner der begleitenden sich umsehen, sonst stirbt er bald. $W u 466$ 
604. Wann en grankes bang is es misst schtærøe, duts; wạnns aber schtærb̄e will kannns net. $(B e, L h)$

If a sick person is afraid he will have to die, he will die; if however he wants to die, he can't.

Fürchtet sich ein kranker vor dem tode, dann stirbt er; sehnt er sich nach dem tode, wird er gesund. $Z 413$

605. Sō ąs en grankes leichter schtærbe kann brauch mer em juscht 's koppekissi weknemme, no schtærbts glei. (Af)

So that a sick person may die easily, take away his pillow.

Dem sterbenden muss man das kissen unter dem kopf fortnehmen, dann wird ihm der tod leichter. $B S 33.119$; $Z$ f $D M 4.4$

606. Wann ebber as tme hot net schtærbe kann, soll mer der imekærb rike, no schtærbt er glei. ( $B e, L b, L h)$ If a bee owner lingers and cannot die, move the bee hive and death will soon come.

607. Wann ēns net schtærbe kann muss mer alles im haus ufschlíse, schublåde un alles. (Lnc, $M r, M t, S n$; Heidelberg)

If a sick person cannot die, all locks, doors, drawers etc. should be unlocked.

Boxes in the house being unlocked makes them die easy. $V S L 2.577$.

In many places it is supposed that the departure of life is delayed so long as any locks or bolts in the house are fastened, as they are supposed to hinder the soul in taking its leave of the body. D Eng 229

608. Wạnn ēns net schtærøe kann muss mer der bærmedi'kel an der ūr schtoppe. (Be, $B u, C, L b, L h, L n c$, $M r, M t, N a, S n, Y)$

If a person dies hard, stop the clock and the end will soon come.

Wenn jemand im sterben liegt, muss man die uhr stehen lassen. $W u 457$ 
609. Wănn en grạkes net schtærbe kănn nemmt mern fun de federe wū er druf leit, nō schtærbts glei. ( $B e$, $C, D, L b, L h, L n c, M t, N a, S c, S n, Y$ )

To hasten dissolution, remove the feather bed or pillows from under the sick person.

Wenn ein kranker oder sterbender hühner-, tauben- oder andere vogelfedern unter sich hat, so kann er nicht sterben. $G R 529$

In Yorkshire occurs the notion that cocks' feathers in a bed retard death. $D Y 59$

610. Wạnn en grankes net schtærbe kann lēkt merms teschtement' u'nich der kopp. $(C, S c)$

To hasten death, put a Testament under the head of the sick person.

Man legt dem sterbenden eine bibel oder ein gesangbuch unter das kinn. $W u 458$.

611. Wąnns hēsst 's wǣr ebber gschtærbe un er is net, lēbts noch lạng. (Af)

A person erroneously reported dead will live for a long time.

Von wem es irriger weise heisst, er sei gestorben, wird sehr lange leben. $Z 358$

612. In ălte zeite hen si âls en dōdes uf en börd gelēkt un der kopp driber nunner henke losse, sō a as es dōd gråd in der himmel guke hot kenne. $(B e, L h, S n)$

In olden times the corpse was laid on a board, so that the head hung down over the back of the board and thus enabled the deceased to look straight into heaven.

Nach dem waschen und ankleiden der leiche wird in Oberfranken der tote auf das totenbett gelegt. $L V 104$

613. Wanndme dōde ē'nich glēd å duscht fume lebe'ndiche wærts glei grank un å nimmi gsund oder schtærbt glei nō. ( $(B e, D, L n c, M r, M t, S n, Y)$

If the clothes of some one living are used as a shroud for a corpse, that person will soon fall fatally ill or die. 
Kein getragenes hemde soll man zum sterbekittel schenken, sonst zehrt der, dem es gehörte, so lange ab, bis das hemde verwest ist. $G 3.1063$

A corpse is not allowed to be buried in the clothes of a living person, lest as the clothes rot in the grave, that person to whom they belonged should waste away and perish. $D Y 83 ; C S A 1269$

614. Mer muss es fenschtēr ufmache wann ēns schtærbt, so a d di sēl naus kann. $(B e, B u, L n c, M r, M t, Y)$

Open the windows in the death chamber immediately after death so that the soul can get out.

Die fenster in der stube des gestorbenen öffnet man sofort, damit die seele hinausfliegen könne. $L 372 ; G 3.191$

In West Gloucestershire they throw open the windows at the moment of death. $V S L 2.577$

Doors and windows should be opened and the locks in the house unfastened at the moment of dissolution, to facilitate the spirit's departure. $V S L 2.577$; Guy Mannering, chap. 27.

615. Di İme muss mer rike wann di leicht færtgēt oder si gēne dōd $(S c)$ oder sin nix mē wǣrt. (Be,Lb,Lh) The bee hives should be moved when the funeral leaves the house, else the bees will die or be worthless.

The bee hives should be turned at the moment the corpse is carried out of the house. $V S L 2.590$

616. Lēk en dōdes uf wå'sem, sell hânts. (Mr, Sc)

A corpse should be laid on sod to prevent decomposition.

A fresh sod laid on the breast of the corpse prevents decay. $V S L 2.586$

617. Fìl leit ferhenke di schpiğel mit grēp wănn ēns dōd leit im haus. $(A f)$

Mirrors should be covered with crepe immediately after a death in the house.

Die leiche darf sich in keinem spiegel sehen, sonst holt sie sich einen aus der familie nach. Man muss daher den spiegel aus dem totenzimmer entfernen oder ihn wenig. 
stens mit einem laken verhängen. $B S 33.119 ; M D V$ 269

Looking glasses and all shining objects in the room are to be covered with white cloths and the clock is stopped and shrouded to show that with him time is over. $V S L$ 2. 590 .

618. Wạn ebber schtærbt muss mer di piktschers im leichehaus gē'ich di wand drēe. $(\mathrm{Be}, \mathrm{C}, \mathrm{D}, \mathrm{Mr}, \mathrm{Na}$, $S c)$

Pictures must be turned to the wall in the house of mourning.

Sobald jemand gestorben ist, verhängt man die bilder usw. bis nach dem begräbnis mit weissen tüchern. Wu 459; $C S A 1243$.

619. Wạn ēns schtærbt muss mer di schpiğel rumdrēe. (Af)

The mirrors should be turned to the wall immediately after death in the family.

Die leiche darf sich in keinem spiegel sehen, sonst holt sie sich einen aus der familie nach. $B S 33.119$

620. Wannns me dōde ins gråb reğert, gēts dōd in der himmel ( $B e, L b, L n c, M r, M t, N a, Y)$ oder wanns nei schnēt. $(B e)$

If it rains or snows into a grave the dead will go to heaven.

Wenn es in ein neues grab regnet, so ist der gestorbene selig. $W u 197$.

If rain falls on a coffin it is supposed to indicate that the soul of the departed has arrived safe. $V S L 2.591$

621. Wems ins gråb reğert is gūt ernērt. $(N u)$

Well cared for is he into whose grave it rains.

622. Wạnn ēns fersof'fe is un mer kanns net finne, dut mer'n lēb brōt ufs wăsser. Wū der kærper leit bleibt der lēb brōt schtē- $\quad(B e, C, D, L b, L h, L n c, M t, N a$, $N u, S c, S n, Y$ )

If any one has been drowned and the body cannot be found, throw a loaf of bread into the water. The loaf 
will remain motionless over the spot where the corpse lies.

Um die leiche eines ertrunkenen $z u$ finden, schreibt man seinen namen auf ein brot und wirft es ins wasser, so schwimmt es an den ort, wo der ertrunkene liegt. $L 344$

A mode of discovering a body drowned in a stream or river was to put a loaf into the water at the spot where the unfortunate fell. The loaf floated down the stream till it came above the body when it began to whirl round and round. G Scot 208

623. Es wært fîl en licht gebrennt in der schtub wūn dōdes leit. $(A f)$

A light is frequently burned in the room where the corpse reposes until the day of burial.

In dem zimmer, in dem die leiche liegt, darf bis zur beerdigung derselben das licht nicht ausgehen, sonst spukt der tote oder zieht bald einen noch lebenden nach sich. $B$ S 33. 119

A candle or two were kept burning constantly beside the corpse. $G S \operatorname{sot} 207$; $S H S 241$

624. Wămmer der schpiğel net rum'drēt ąn re leicht gebts glei wider ēni. (D)

If the mirror is not turned to the wall while the corpse is still in the house there will soon be another funeral. 


\section{WITCHES}

625. En schtreissel hexegraut soll mer uf der Sant Johannisdåk an di dîr henke. Sell hạlt di hexe draus. $(B u, C, D, L h, L n c, M r, N u, S c)$ un di mike wek. $(\mathrm{Mr})$

Fasten a sprig of St. John's wort (Hypericum perforatum) to the door to keep out witches or flies.

Johanniskraut vertreibt hexen und teufel, daher dieser aus bosheit alle blätter mit der nadel durchsticht. $G$ 3. 190

626. En gensfūs uf di schtâlldîr mạche hạlt di hexe draus. (Be, C, D, Lh, Lnc, Na, Sn)

Put the foot of a goose [draw a pentagram?] on the stable door to keep the witches out.

Macht man ein trudenfuss an die tür, so müssen die hexen fern bleiben. $G 3.644$

627. Wạnn di kì ferhext sin nặgelt mern gro'tefūs añ di dîr nō gēn di hexe wek uns hạlt si å draus. $(B e, C$, $D, L b, L h, L n c, N a, S c)$

Nail a toad's foot over the stable door to drive and keep the witches out of the stable.

Macht man einen trudenfuss an die tür, so müssen die hexen fern bleiben. $G$ 3.644

628. Mạch gro'tefîs mit greid an di bett'låd, sell hạlt di hexe wek $(B e, M r)$ oder i'newennich o'bichs fenschter oder dìr. $(M r)$

To keep away witches, draw toads' feet with chalk on the bedstead or in the room above window or door.

Gegen hexen werden in der nacht vor neujahr und drei könige drei kreuze an die stalltüre gemacht. Alem 20. 281

629. Schneid re schwærze katz di ōre ąb, ferbrenn di ōre un ffder der hex selli esch. (Lnc; Kaiserslautern) Cut off the ears of a black cat, burn them and feed the ashes to the witch. 
630. Wạmmer ferhext is soll mer der bēse fær di dîr lēğe, uns ërscht as der wēk kummt un schtellt en uf is di hex. (Af)

When bewitched, lay the broom before the door. The first person to come along and pick it up is the witch.

Legt man einer hexe einen besen so in den weg, dass sie darüber schreiten muss, so wird sie unmächtig und kann kein unglück stiften. $G 3.250$

631. Wạmmern lēb brōt ins wassser schmeisst ferdreibts di hexe. (Nu, $Y$; Kaiserslautern)

Throwing a loaf of bread into water will drive out witches.

632. Wanns brōt net gēt is es ferhext. (Be, Lnc, Y; Heidelberg)

If bread won't rise, it is bewitched.

633. Fær en hex zu fange, schneit mer di zwē hemm'ærmel aus em seim mann seim hemm un ferbrennt si. (Be, $L b, Y$; Neustadt)

To discover a witch: cut the two sleeves out of your husband's shirt and burn them.

634. Schtell der bēsemschttl in di dîr, nō kumme ken hexe ins haus. ( $\mathrm{Na}$; Heidelberg $)$

Put the broomstick against the jamb of the door and no witch can enter.

635. Wannd ausfinne witt wǣr di hex is, gē drå un mōl si ab un nemm en flint wūd en zēe sent schtik nei $\sim$ gelåde hoscht un schîss noch em bild. Wūds bild dreffscht, hot di hex en mærik uf em leib. (Lh)

To discover a witch: draw a picture of the suspect, load your gun with a dime, and shoot at the picture. The spot where you hit the picture will correspond to the mark to be found on the body of the witch.

Eine hexe kann man verwunden, wenn man mit einem geldstück schiesst. $W u 160$

636. Wann en hex im haus is soll mer mit der linke hand en handfoll grop sạlz ins feier schmeisse. (Be, Lnc, $S n, Y$ ) 
If there is a witch in the house throw a handful of coarse salt into the fire with the left hand.

Sind verdächtige leute im hause gewesen, so wirft man salz ins feuer. $W u 283$

637. Wănn en kind ferhext is soll mer sei hemmli ausztğe i'toer der kopp so as es letz is un di ærmli ( $L n c, S n$, $Y$ ) oder glēder $(N u)$ hinner di dîr fescht petze. (Heidelberg)

When a child is bewitehed pull its shirt over the head wrongside out and wedge the sleeves or clothes behind the door.

638. Mer soll ken a ${ }^{\prime} b^{\prime}$ gschtumpter bēsem ins freie schtelle schunscht nemme di hexe en un reide druf dærich di luft. $(L h, N a)$

Witches will take a worn-off broom and ride on it through the air.

Die hexen reiten auf besen und mistgabeln. $Z 514$

639. Wann ebber ferhext is 's ērscht ans kummt fer ebbes lēne di hex. (Af)

If you are bewitched the first person to come to you to borrow from you is the witch.

Hat eine was verhext und man verbrennt es, so kommt die hexe und will etwas entlehnen. $G 3.645$

640. En hex schritt net I'bern bēsemschteke. (Lnc)

A witch will not step over a broomstick.

Die hexe stösst den besen weg, gute leute schreiten drüber. Wu 130

641. Wănn en hund ferhext is a er net blaffe (gauze, Lnc) kann, brauch mern juscht "wạsser" hēse, nō kann er wider bląffe. $(B e, B u, C, D, L h, L n c, S c, S n, Y$; Kaiiserslautern)

If a dog is bewitched so that he can't bark, call him "water" and he will be cured.

642. Mer låd en hör'ni kuğel in en ferhex'ti flint. (C, Mr; Kaiserslautern)

Ioad a bewitched gun with a bullet of hair. 
643. Wąnn en flint ferhext is schtekt mer zwè schpelle i'ber nanner sō as es en greiz mạcht uf der flint. $(C, D$, $M r, M t, N a, S c, S n, Y$ )

When a gun is bewitched stick two pins on the gun in the form of a cross.

644. Wammer am sēfkoche is un en weibsmensch kummt is di sēf ferhext. (Lnc, Sc, Y)

If you are boiling soap and a woman happens along, the soap will be bewitched.

645. Wạnn di hex wek is is gewēn'lich en schwærzi kątz dō. $\quad(B e, C, L b, L n c)$

When the witch disappears, a black cat appears.

In schwarzer katzengestalt kommen die hexen gerne. $V \boldsymbol{A}$ $S 1.325$

The familiar form of a witch is always a black cat. Ir 2 . 10

646. Es macht di hexe kumme wannd sibe neie nōdle ime kind sei wasser in en bottel duscht un si no eischlisscht. (Be,Lb; Kaiserslautern)

The witches will appear if you put seven new needles and some urine of a child into a bottle and then put the bottle under lock and key.

647. Wạnn en mạnn en fïrblet'terich glēblåt nōdråkt kąnn en nimand ferhexe. $(B u, C, L h, S c)$

Wear a four-leafed elover and nobody can bewitch you. Gegen verhexung soll gut sein, wenn man fünfblättrigen klee bei sich trägt. $V A S 1.330$

Witcheraft will have no power over the possessor of the four-leafed shamrock. $\operatorname{Ir} 2.103$

648. En k't'fotz in der geilschtall kenkt hạlt di hexe draus. $(Y)$

Hang the vagina of the cow into the horse stable to keep out witches.

[This is a direct survival of the old Germanic heathendom. Cf. Golther, Handbuch der Germanischen Mythologie, pp. 575-6.] 
649. En ferhexti flint kămmer mit re hōr'ne kuğel fixe. (C, $M r)$

Load a bewitched gun with a bullet made of hair.

650. Wann en flint ferhext is muss mer si mit re sil'berne kuğel låde. $\quad(C, D, L h, M r, M t, N a, S c, S n, Y)$

To break the spell in a bewitched gun, load the gun with a silver bullet.

Silver is always considered an antidote against witcheraft. $C F N u 4.54$

651. Dũ $\tilde{e n}$ zēe sent schtik in en ferhexti flint. $(B e)$

Put a dime into a bewitched gun.

Verwunden und töten kann man die hexe, wenn man ein silbernes geldstück auf sie schiesst. $W u 283$

652. Wann en flint ferhext is muss mer si mit re silberne kuğel låde. $\quad(C, D, L h, M r, M t, N a, S c, S n, Y)$

To break the spell in a bewitched gun, load the gun with a silver bullet or a dime.

Eine hexe kann man verwunden, wenn man mit einem stück erbsilber oder einem geldstück schiesst. $W u 160$ Shoot at a witch, if you wish to hit her, either with a crooked sixpence or with one having a hole in it. $C F N u$ 4. 54

653. Wạnn en flint ferhext is, lēk si in en grik un loss wąsser dærich låfe. Nō kann di hex nimmi pisse bis si zu der kummt. $(B u, M t)$

If you lay a bewitched gun into a creek the witch can't urinate until she comes to you for forgiveness.

'654. Oierschåle muss mer ferbrenne, so as di hexe ken gewalt hen iber di himmel. (Lnc; Heidelberg)

To prevent chickens from being bewitched, the eggshells should always be burned. 


\section{DOGS AND CATS}

655. En schwærzi kạtz bringt unglik. (Bu, $C, D, L b, M t$, $S n, Y)$

A black cat brings bad luck.

Man soll im hause keine schwarze katze halten, sondern eine graue. Alem 20. 284

656. En schwærzi katz is es glik uf me höf. (Be, $D, L h$, Lnc, $\mathrm{Mr}, \mathrm{Na}, \mathrm{Nu}, \mathrm{Sc}$ )

A black cat brings luck to the premises.

If a black cat comes of her own accord to your house, keep her, she is a good spirit; but do not bring her, she must come freely, of her own good will. W Ir 69

657. Wănn en schwærzi katz em engēğe kummt, bringt si em glik. ( $L h, M r, N a, S c, Y)$

Meeting a black cat is an omen of luck.

If a strange cat comes to your house and remains domestieated it brings good fortune. $F R 1.8$

658. En schwærzi katz is en unglik in re fạmi'lie. (Be, $L b$, Lnc, Na, $\mathrm{Y}$; Heidelberg)

A black eat brings bad luck into a family.

659. Wǣr hund un katze gleicht, gleicht sei mann oder frå. $(A f)$

A person fond of dogs and cats will make a good husband or wife.

Wer die katzen gerne mag, mag auch die mädehen. $V A S$ 1. 117

Welche jungfer die katzen lieb hat, die bekommt einen frommen mann. $G R 552$

660. Wåmmer junge katze å rēkt eb si di åğe uf hen losst di alt si ferhun'gere. (Af)

If you touch kittens before their eyes are open, the mother eat will let them starve.

Dann kriegen sie "matze" augen. Hlbg. 
661. Ēnich ebbes wū fume wt'diche hund gebisse is wært in nein dåk, nein woche, nein mū'net oder nein jōr widich. $(A f)$

An animal or human being that was bitten by a mad dog will go mad in nine days, nine weeks, nine months or nine years.

Die wasserscheu nach einem biss von einem tollen hunde soll am 9. tage, in der 9. woche, im 9. monat, oder nach 9 jahren auftreten. $A J 257$

662. Wạmmern katz schisst hot mer ken glik. (Bu,Na) Shoot a cat and your luck is gone.

663. Wạmmern kạtz schissst hot mer ken glik mit de geil. $(A f)$

If you shoot a cat, you will have bad luck with your horses.

664. Wạmmern kạtz schísst hot mer sibe jōr ken glik. ( $A f$ )

Seven years of bad luck follow the killing of a cat.

Wer eine katze tötet, hat 7 jahre lang kein glück. W 72

665. Wạmmer dr schpíllumbe im kaf'fi kocht un gebt $\mathrm{dr}$ katz oderm hund defu'n, låfe si net fært. $(D, L h)$ If you boil the dishcloth in coffee and give some of it to dog or cat, they will not stray from home.

666. Wạn di katz sich Sun'dåk mærğets wescht, seller wēk wū der schwanz hĩ point kummt der bsuch hǣr. $\left(L b, L n c, M r, M t, N a, S c, s^{s} n, Y\right)$

The direction in which the cat's tail points when she washes herself on Sunday morning indicates the direction from which visitors may be expected.

667. Di flint oder bix wū mern kântz mit schísst dut nix mē dēte. ( $A f)$

The gun or rifle with which you shoot a cat won't kill after that.

668. Wạmmern hund Wasser oder Feier hēsst kann en nt'mand ferhexe. $(B e, D, M t, L n c, S c, S n, Y)$ 
Call a dog "Water" or "Fire" and he can't be bewitched. Um den hund vor behexung zu schützen, nennt man ihn Wasser oder Strom, denn das wasser kann nicht behext werden. $W u 434$

669. Wann en katz ìr junge fum wasser weknemmt gebts hōchwassser. (Lnc, Nu)

When a cat removes her kittens from near the bank of a stream, it is a sign of high water.

670. En hund gēt der net fært as aus deim schū fresse losscht. $(B e, S n, Y)$

Let a dog eat out of your shoe and he will not stray away. Um hunde dem menschen anhänglich $\mathrm{zu}$ machen, legt man sich ein stück weissbrot unter die ferse, läuft damit, bis man in schweiss kommt und gibt das so vom schweiss durchdrungene brot dem hunde $z u$ fressen. $W u 433$

671. En bei'gelof'ni kạtz bleibt wạmmere di dōbe uf em o'fe reibt. $(B e)$

A stray cat will not run away, if you rub her paws on the stove.

Damit katz und hund nicht entlaufen, treibe man sie dreimal um den herd und reibe sie an die feuermauer. $G$ 3. 155

If a cat from a distance becomes restless and tries to make her escape, put her into the cold oven, for it is said that the effect upon her will be that she will forget her former home as completely as if she had lapped Lethe's water. F $R 1.8$

672. Sō ăs en hund net færtlåft, wærmt merm brōt u'nich em årm un ft'derts em. (Be,C,D,Lh,Lnc, Mt, Na, $S c, S n, Y)$

To prevent a dog from running away feed him some bread which you have warmed in your arm pits.

Wenn man einen hund schnell an sich gewöhnen will, so lege man brot oder käse unter die achsel, laufe, bis man in schweiss kommt und gebe ihm dann das brot. $Z \mathbf{Z} 798$; V A S 1.118 
673. Sõ ăs di kątz $(B e, D, L b, L h, M t, S c, S n, Y)$, oder der hund $(D, N a)$ net færtlåft, soll mer ne di fîr discheke a्kschåbe un ins fresse dü̃ .

Scrape the four corners of the table and put the scrapings into the food of dog or cat and they will not leave their home.

Man schabt drei oder vier tischecken an und tut dies dem vieh in den trank, um es zu gewöhnen. $W u 435$

674. En katz as mer net bei der nạcht hōlt låft em fært. (Be, C, D, Lb, Lh, Lnc, Mt, Na, Sc, Sn, Y; Heidelberg)

Fetch a cat at night if you would have her stay.

675. Wammern kạtz in der schpiğel guke losst låft si net fært. (Be, Bu, Lb, Lh, Lnc, Na, Sc, Y)

Show the cat her image in the mirror and she'll stay.

Haustiere besonders katzen macht man anhänglich, wenn man sie dreimal in den spiegel sehen lässt.......Alem. 20. 284

676. Wammern hund grikt soll mern loch in di direschwell bōre wū mer uf un ạb gēt, fum hund seine hōr fạnne uf der schtærn abschneide, oder di hōr fum tip fum schwanz $(L n c)$ un selli hōr nō ins loch dū̃. Nō macht mern zappe un schlankt en in drei schtrēch nei , un der hund gēt net fært. $(B e, C, L b, L h$, $\mathrm{Na}, \mathrm{Sc}$ )

To prevent a dog from running away, bore a hole into the doorsill, cut a heft of hair from the front of the dog's head or the hair from the tip of his tail and put it into the hole. There make a peg and close up the hole with it, driving the peg home with three blows.

677. Wann em sei kind fært is muss mer sei nåme drei mōl rūfe dærich en gnærreloch un gēğe sunn'uf. $(B u, S c, Y)$

If your child is lost, eall it three times through a knothole facing the east. 
678. Wạnn em sei ${ }^{\sim}$ hund fært is soll mer nein mærğe dærich en gnærreloch gēğe sunn'uf em hund rüfe, ąter der ochtem halte, no kummt er zuri'k. (Be, Bu,Lb,Lh, $\mathrm{Mr}, \mathrm{Mt}, \mathrm{Na}, \mathrm{Sc}$ )

If your dog is lost call him through a knothole facing the east nine mornings in succession, holding your breath, and the dog will return.

Ist einem ein hund fortgekommen, so muss man ihn an drei abenden während des abendläutens dreimal durch ein wagenrad mit namen rufen, so kommt er wieder. $W u 434$

679. Wannn en hund gautzt, roppt mern fen'seschtåke raus un schtekt en 's un'nerscht 's e'berscht neĩ , sell schtopts. $(S n)$

If a dog barks, pull a fence rail ont of the ground and put it back upside down.

When you hear a dog howl, take off your shoe from the left foot, and spit upon the sole, place it on the ground bottom upwards and your foot upon the place you spat upon, which will not only preserve you from harm, but stop the howling of the dog. D Eng 101

680. Schneit re katz hōr fum schwanz a ab un dråk si im rechte schū, nō låft der di katz net fært. $(N u$; Kaiserslautern)

Cut some hair from the cat's tail and wear it in your shoe, and the cat will not stray away.

681. Wămmern hund schærrt wū er sich net grạtze kạnn bleibt er. $(\mathrm{Be}, \mathrm{Na})$

If you scratch a dog where he can't scratch himself he won't run away.

682. Schåb di disch'eke ąb un fider si em hund, nō låft er net fært. $(L h, M r)$

Scrape the corners of the kitchen table and feed the scrap. ings to the dog to prevent him from running away.

Schabe dem hunde oben am tisch von den vier tischecken ab und gib ihm zu fressen. Hoh 15 


\section{MOVING}

683. 'S èrscht ans mer in en haus dut wü mer ht ztkt is di bąk'mōl. (Bu, D; Freiburg)

The first article to be carried into a house at a moving is the kneading trough.

684. Wammer ame zuk der ofe 's èrscht ins haus dut fechte di leit fíl. $(D, S c)$

At a moving, never put the stove into the house first, or there will be many quarrels.

685. 'S is gūt glik ebbes zurik'zulosse wạmmer ztkt. (Be, Mt; Heidelberg)

Leaving something behind when removing is a lucky omen.

686. Alter bēsem dærf mer ke'ner mitnemme wammer ztkt. (D, Lnc, Sc; Heidelberg)

Never take an old broom when moving.

687. Mer hot ken glik wammer zikt un nemmt oier mit. (Bu, D, Lb, Lnc, Mr, Mt, Sn)

Never take eggs with you when moving.

Die braut muss ein brot und andere lebensmittel in das neue haus mitbringen, aber nie darf sie eier mitbringen. $W u 373$

688. Wạnn en fạmi'lie ærğets hî̃zikt soll merm kind gråd kąlt wassser geઈe, nō grikts ken hēmwē. (D)

The child should be given some cold water immediately after moving to prevent its becoming homesick.

689. Wạn ebbes ferbrecht anme zuk gebts unglik. (Be, $S c, S n, Y)$

If anything breaks during a moving it forebodes bad luck.

690. Ame zuk muss ebbes fun glås ferbreche un wanns juscht $\overline{\mathrm{e}}^{\sim}$ schtik is oder mer hot ken glik. $(B u, C$, $D, L b, L h, L n c, M r, M t$; Heidelberg)

The breaking of glassware, even if only a single piece, at a moving is lucky. 
691. M'r soll me mąnn ag uf seim pránerti wūnt net helfe ztğe oder mer nemmt ems glik. (Be, $L h, S c)$

It is unlucky to help your tenant in moving.

692. Eb mer zikt muss mer zu'ker, sals un peffer ins haus

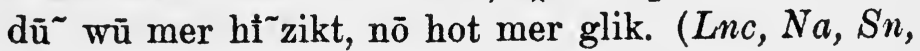
$Y$ )

Before removing to a new home, send on ahead some sugar, salt, and pepper; this will bring good luck.

Wenn man salz und brot zuerst in ein haus bringt, das man bezieht, so hat man darin keinen lebensmangel. G 3. 1142

To place a Bible, some salt and some oatmeal in the cupboard of a dwelling house on entering on the occupation of it brings peace and plenty. $V S L 2.132$

694. Wạmmer aer'ğets hĩ zìkt, soll mern be'sem un en lēb brōt fannehǣ'r schike, no grikt mer ken hēmwē. (C, D, Lh, Lnc, Na, Y; Heidelberg)

When removing to another house, you should send a broom and a loaf of bread on ahead, to prevent homesickness.

695. Wạmmer zîkt soll mer di katz net mitnemme oder mer hot ken glik. (Af; Heidelberg)

Taking the eat with you when moving brings bad luck.

When changing your residence it is unlucky to bring a cat with you. $W \operatorname{Ir} 69$

696. Mer dǣrf di kạtz net mitnemme der dåk wū mer zìkt, mer muss si schpēter hōle. ( $A f)$

You must not take the cat with you the day you move, it should be fetehed later.

Die katze muss allein kommen. Hlbg.

697. Di kạtz dæ'ref mer går net mitnemme wămmer ztkt. $(B u, M t)$

The cat must not be taken along when moving.

It is unlucky to take a cat with you in removing. $C P \& P$ 523 
698. Wănn en fremmi kạtz in em sei ${ }^{\sim}$ haus kummt gråd wămmer gezōğe is soll mer si palte fer glik. (Sn; Heidelberg)

If a stray cat comes into your house immediately after moving keep her for luck.

699. Wammer in en nei haus zîkt, schtærbt ēns aus der fámi'lie oders gebt ēns dezü'. $(N u)$

Move into a new house and there will be a death or a birth in the family.

Aus einem neuerbauten hause wird spätestens im zweiten jahre eine leiche getragen. $W u 209$

To build or even rebuild a house is always fatal to one member of the family. $D Y 54$

700. Freidåks gflitzt-kærz gsitzt. (C, Lnc, $M r, S c, S n)$

Friday flittings

Short sittings.

Am Freitag darf man die wohnung oder den dienst nicht wechseln. $W u 61$

Never move into a new house on Friday. W Ir 63

701. Me zuk dǣrf mer net nōguke oder si hen ken glik. (Bu, Lb, Lnc, Mt, Na; Kaiserslautern)

Never watch a moving out of sight, for it will bring bad luck.

702. Wammer Mittwochs oder Freidåks zikt hot mer ken glik ( $B e, C, L b, L h, M r, N a, N u, S c, S n)$ oder mer hot fil granke leit. (do.)

Moving on Wednesday or Friday will bring bad luck or much sickness.

Mittwoch und Freitag sind verworfene hexentage. G 3 . 613

703. Wạmmer Mūndåks zikt hot mer ken glik. ( $B e, C, L b$, $L h, M r, N a, N u, S c, S n)$

It is bad luck to move on Monday.

Man muss auf keinen Montag in den dienst treten, in ein haus ziehen, oder sonst was beginnen, solches wird sonst nicht wochenalt. $G 3.1140$ 
No one should remove on a Monday, because the house affairs will not thrive. .V $S L 2.1 .260$

704. Mittwochs gflitzt-kærz gsitzt. (Be, Bu, Mt, Mr, Na) $\mathrm{Na}$ )

Wednesday flitting

Short sitting.

705. Wǣr Sạm'schdåks zikt bleibt net lạng. (Be,C,D, $. L b, L h, L n c, M t, N a, N u, S c, S n, Y$; Heidelberg) Move on Saturday and you will not stay long.

Never remove from a house or leave a situation on Saturday. $\operatorname{Ir} 2.115$

706. Wămmer zikt muss mer ki fanne hǣr schike schunscht hot mer ken glik. (Be, Bu, Lh, Mr, Mt, Na, Nu, $S c, S n, Y$; Freiburg)

The cows should be sent on ahead of the moving.

707. Anme zuk gēn di kì hinnenō'. (C, D, Lb, Lnc; Heidelberg)

The cattle follow the moving. 


\section{HOMESICKNESS}

708. Wănn ēns hēm'wē hot soll merm en messerschpitze foll grund fume greiz'påd im gårde in der kaffi dū . (C, D, Lh, Lnc, Na, Sn, Y)

As much ground taken from a cross-path in the garden as will cover the point of a knife, will cure homesickness when put into coffee.

Wenn jemand in die fremde zieht, so soll man ihm, ohne dass er es weiss, kaffee kochen, in den man erde von einem frischen grab getan hat, damit er nicht heimweh bekomme. $H Z 47$

709. De weibsleit nēt mer sălz un brōt in der un'nerrok, nō grìğe si ken hēmwē. ( $M t, N a, L b, S c)$

Women will not become homesick if you sew salt and bread into their petticoats.

Wer aber in die fremde zieht, nimmt ein stück hausbrot mit sich, dann ist er unterwegs sicher vor bösen geistern und bleibt in der ferne frei von heimweh. $W u 129$; cf. $W u 282$

710. Wạnn ēns 's hēmwē hot, soll mer seĩ glēd ufmạche un sậlz in di såm nēe. $(B e, L n c, N a, S c, S n, Y)$

If a person is homesick, rip some part of his clothing and sew salt into the seam.

711. Wạmmer ebber un'wissend salz in der ho'sesak nēt grikts ken hēmwē. $(B e, C, L b, L n c, N a, N u, S c, S n$, $Y$ )

Sew some salt in a man's trouser pocket without his knowing it, and he will not become homesick.

712. Sõ ạs ēns 's hēmwè net grikt solle di leit wūs dehēm is İm fí'salz ins hemm nēe. (Be,Lb,Lh,Lnc, $M r, M t, N a, S n, Y$ )

If a person gets homesick let some one in the family where the person is staying sew coarse salt (or rock salt) into his shirt. 
713. Wạnn ēns hēmwē hot soll mer grund fun dehēm' mitnemme un en $\mathrm{tm}$ in der kăffi dū̃ . $(B e, B u$, $C, M t, Y)$

Take ground with you from home and put it into your coffee to cure homesickness.

714. Mer solls hemm auszì̆ge un letz å dū , nō grikt mer ken hēmwē. (Af)

To prevent homesickness take off the shirt and put it on again wrong side out.

Gegen heimweh schützt man sich, wenn man das hemd verkehrt anzieht. $W u 408$

715. Mer soll der ka'ffi dærich der schplllumbe seie, no grikt mer ken hēmwē. $(B e, B u, C, D, L h, M r, M t$, $S c, S n)$

To prevent homesickness, strain coffee through a dish cloth. 


\section{SERVANTS}

716. Koch der neie måd der schpillumbe im kå'ffi, nõ låft si net fært. $(C, M t, N a, S c, S n, Y$; Freiburg)

Boil the dishcloth in coffee, so that your servant will not leave.

717. Sei der neie måd wassser dærich der schpillumbe, nō låft si der net fært. $(C, S c, S n, Y)$

Water strained through a dishcloth and given to the new servant to drink will prevent her leaving her new home.

718. Wạnd en neii måd grikscht, mach si gråd en ēmer foll wassser hōle. ( $L b, L h, N a, S c, S n, Y)$

Require the new servant girl to fetch a bucket of water immediately on her arrival.

Wenn eine magd neu anzieht, so muss sie vor allem einen eimer wasser holen, dann bleibt sie dem hause treu. $W u 403$

719. Di nei måd muss gråd zum schąnschtē ${ }^{-}$nufguke, nō grikt si ken hēmwē. $(A f)$

The new servant girl must look up the chimney immediately on her arrival to prevent homesickness.

Die magd gewöhnt sich an, wenn sie zum kamin ihres diensthauses hinaufsieht. $B \quad M 20$

720. Nē der neie måd salz in di glēder. ( $L b, L h, L n c, M r$, $\mathrm{Mt}, \mathrm{Na}, \mathrm{Nu}, \mathrm{Sn}, \mathrm{Y}$ )

Sew some salt into your new servant's clothes.

721. Schåb der neie måd fun der díreschwell ăb un dūs re ins esse, nō låft si net fært. (C, Lnc, $M r, S c, S n, Y)$ Put some of the scrapings of the doorsill into your new servant's food, so that she will not become homesick and leave. 
722. Wånnd en neii måd grikscht schåb di disch'eke aab un dūs re ins esse, nō låft si net fært. $(B e, C, L b, L h$, $L n c, M r, N a, N u, S c, S n, Y)$

Scrape the edges of the kitchen table and put the scrapings into the victuals of your new servant girl; then she won't be homesick and leave.

723. Di nei måd sott di bălğe zēle ōbeds wann si ins bett gēt, no grikt si ken hēmwē. $(C, S c)$

The new servant should count the timbers in her room the first night she sleeps in her new home.

724. Wạmmer Sạmschdåks ei 'schtēt bleibt mer net lạng. (C, Sc; Heidelberg)

If you hire out and begin work on Saturday you won't stay long. 


\section{STOCKRAISING AND VETERINARY MEDICAL SUPERSTITIONS}

725. Wạnn en kū der I'drich ferlōre hot soll mern schptl. lumbe schtēle un en re fídre. ( $B u, C, D, L b, M r$, $\mathrm{Nu}, \mathrm{Sc}, \mathrm{Y}$ )

If a cow has indigestion, steal a dishcloth and feed it to her.

726. Wạnn en kū der ì'drich ferlōre hot soll mer ǣrğets hî $\sim \mathrm{ge}^{\sim}$ un en schtik brōt schtēle uns der kū fiddre. $(B e, B u, C, L h, L n c, M t, S c, S n)$

To cure indigestion [lit. if a cow has lost its cud] in a cow, feed it some bread which you have stolen.

727. Wạn en kū der ì'drich ferlōre hot soll mer butterbrōt fume noch'ber hōle uns re fîddre ẩer mer dærf nix schwetze. (Lnc, Nu; Kaiserslautern)

A cow's indigestion may be cured by going to a neighbor's house and in silence getting a piece of bread and butter, which is fed to the cow.

728. Wann en gaul gfaun'dert is, nemm en abbel oder gru'mbî̀, schneit si in der mitt dærich, dũ $\tilde{u}^{\sim}$ drei wischel hōr nei fume ferbærgne blatz un fiders 'm gaul. (Be, Lnc, Na, Sc; Neustadt)

Three locks of hair, cut from a person's private parts and placed between the halves of an apple or potato, when fed to the horse, will cure founder (laminitis).

729. Fider me gaul as gfaundert is en fei gschnittni wi'selhaut. (C, Lnc, $M t, S c)$

Cure founder (laminitis) by feeding the horse a weasel's pelt cut fine.

730. Hōr fun drei ferborgne bletz nemmt en faunder. $(M t)$

Hair taken from three private parts of a human being and given to a horse will cure founder (laminitis).

Wenn sich eine kuh bläht, nimm drei haare von einer frauen scham und gib sie der kuh ein. Alem 8. 125 
731. En gaul mit zwē kì'schlek is ex'trå gūt. ( $C, M r, Y)$

A horse with two cowlicks on its head is extra fine.

Hat das kind zwei haarwirbel, wird es ein kluger mensch. $Z 13$

732. Wạnn en kū dik wært mạcht mer si i’torn schtrik oder fens tschumpe. $(B u, C)$

Cure tympanitis in a cow by making it jump a rope or a fence.

733. Reibs wē eider ån re kū mit me hunnskopp. (Be,Lnc, $M t, S c, Y$; Kaiserslautern)

Cure manitis in a cow by rubbing the udder with a dog's skull.

734. Wannn en gaul schpåte hot, reibt mern mit me hunnskoppgnoche. $(B e, C, S c)$

Rub the spavined leg of a horse with a dog's skull.

735. Windgalle a ame gaul reibt mer mit me hunnskopp un lēkt en nō o'tbich di dìr im geilsschtall. ( $D, L n c$, $M r, S n, Y$; Kaiserslautern.)

Rub windgalls on a horse with the skull of a dog, then lay it on the doorjamb in the horse stable.

736. Schneider, schneider, såk mer wū mei kì sin oder ich ropp ders lengscht be $\bar{e}^{-}$raus. $(B e, B u, C, L b, L h$, $M r, M t, N a, N u, S c, S n)$

Spider, spider [probably the vine beetle, Lethrus cephalotes] tell me where my cows are, or I'll tear off your longest leg.

Wenn der hirt den langbein an einem beine hält, so weist das tier mit dem andern bein nach der richtung, wo er sein verlaufenes vieh zu suchen hat. $L 330$

737. Fer ringbōn binnt mern leben'dichi grot druf bis si dōd is. (Lnc, Sn)

Tie a living toad on a ringbone and leave it there till dead. Gegen den krebs der brust des weibes hilft eine kröte darauf gebunden, nachdem man vorher über dieselbe das krenzeszeichen gemacht hat. $V A S 1.485$ 
738. Wănn der schtall foll schpinnewēb is, is 's ft gsund. $(C, D, L b, L n c, N a, N u)$

When the stable is covered with cobwebs the live stock is healthy.

Im stalle, in dem spinnen sind, ist das vieh gesund. $Z f$ D H 1. 236; $Z 833$

739. Reib re kū îr gschwolle eider mit milich. $(B u)$

Rub the udder of a cow suffering with manitis with milk.

740. Wạnn en kū en gschwolle eider hot, soll di melkern 's eider reibe mit me wollne un'nerrok $(B e, B u, D$, $L b, L h, L n c, M t, N a, N u, S c, S n)$ oder mit em un'nerroksåm. $(\mathrm{D}, \mathrm{Mr}, \mathrm{Na})$

To cure manitis, rub the udder with a woolen petticoat or the hem of the petticoat.

Lasse der kuh ein weibsbild mit dem letzten teil des rockes über das geschwollene eiter (einer kuh) fahren, so wird die geschwulst nachlassen, wenn sie noch nicht überhand genommen hat. Alem 11.93

741. Bạssem haut is gūt fer kumetblōder.

The pelt of the oppossum cures collargall.

$(L h)$

Am kummet befestigt man gegen hexen ein dachsfell. Wu 452

742. Fer ku'metblōder dū ${ }^{2}$ en wis'selhaut u'nichs kumet. $B e, B u, L b, L n c, M t, N a, S c, S n, Y$; Heidelberg)

To cure collargall fasten the pelt of a weasel on the collar.

743. En kalb ạs mer uf'złğe will, soll mer juscht nein ims an der kū saufe losse. (Sc)

A calf which is to be raised should suck the cow only three days [lit. nine meals].

744. En kalb ąs mer uf'ztğe will, binnt mer å drei dåk fer follicht. ( $B e, L h, M r, Y)$

Wean a calf three days before full moon.

Kälber müssen bei vollmond entwöhnt werden, oder bei zunehmendem. $W u 443$ 
745. 'S ērscht kalb fume rind ztkt mer net uf, mer ferkåfts. (Af)

The first calf dropped by a cow should not be raised, it should be sold.

Das erstgeborene kalb einer jungen kuh (färsenkalb) darf nicht gezüchtet werden, weil jede erstgeburt zur zucht untauglich ist. $B S 33$, p. 127

746. Reib kōl'el un fett uf all di sei sō as si net fechte wannnd en fremmi zūne in der schtall duscht. $(S n)$ Grease all the pigs with coal oil and fat upon putting a strange pig into their pen, to prevent them from fighting.

747. Sei fechte net wạmmer si anll mit kōlēl schmîrt. (D, $N u, S n)$

Pigs will not fight if all of them are greased with coal oil.

748. Mer schmirt all di sei mit brąn'dewei oder dær wămmern neii zune in der schtall dut. ( $D, L b, M t, N u$, $S c, S n)$

Rub whisky or tar on the backs of all the pigs when putting an additional pig into their pen.

Wird zur kuh ein fremdes kalb gebunden, so streicht man die mäuler beider mit branntwein, dann gewohnen sie sich an einander. Alem 20. 282

749. Wạmmern sau zu annere in der sēm schtall dut, muss mer si mit dærbedt'n schmtre, nō kenne si di fremm net fun de annere kenne. $(A f)$

Pigs will not be able to distinguish the additional pig put into their pen if turpentine is put on the backs of all of them.

750. Wạmmern meii kũ grikt soll mer, eb mer si zu de annere dut, all de kł en wischel hōr fun der schtærn zwische de hærner a bschneide, no fechte di kł net. $(\mathrm{Be}, \mathrm{Na}, \mathrm{Sc}, \mathrm{Y}$ )

Before driving the newly purchased cow into the herd cut a tuft of hair from the head of each animal, between the horns, and the newcomer will not be horned by the rest. 
Man schneidet der kuh zwischen den ohren einen büschel haare $a b$ und vergräbt ihn vor die stalltür, so gewöhnt sie sich ans haus. $W u 439$

751. Wǣr sei fi ērscht fídert di nei'jōrnạcht hots schenscht fî̀ sell jōr. (Be, Lh, Lnc, Mr)

Who feeds his stock first on New Year's night has the sleekest animals all year.

Merkwürdig ist, dasz seit uralter zeit der glaube lebt, das futter, welches nach der [Karfreitags] nachmitternachtsstunde, je bälder, desto besser, dem vieh gegeben wird, dasz das besondere kraft gebe. In der Saulgauer gegend standen die leute oft schon um 2 uhr auf. Wer jetzt noch zuerst erwacht, muss in den stall. A $S 1.387$

752. Wămmern kū druke schtẽ ${ }^{\sim}$ losst, melkt mer si 's letscht mol uf der bo'dem. (C,Lb,Na,Sc)

The last time a cow is milked before going dry she should be milked on the ground.

753. Wammern kū druke schtē $\tilde{e}^{-}$will losse melkt mer si 's

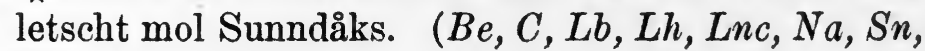
$Y$ )

To dry up a cow she should be milked the last time on Sunday.

Eine abgemolkene kuh lässt man Sonntags trocken stehen. $W u 447$

754. En mannskærl soll en rind 's ērscht mol melke nō schlạkts rind nōch'hæ̈r net. $(B e, B u, D, L b, L h$, $M r, M t, N a, S c ; H e i d e l b e r g$ )

To prevent a heifer from kicking during milking, it should be milked the first time by a man.

755. Wănn en kū blū'tichi mi'lich gebt melkt mer di milich dærich der jut fun re sau. (Lh,Na)

If a cow gives bloody milk, milk it through the atlas bone of a pig.

Man milkt die mileh durch eine schweinsblase. $W u 445$ 
756. Wạn en ōs'foğel iø̄er di scheier flikt gebts dōd fì. $(D, L h, L n c, M t, Y)$

If a turkey buzzard flies over a barn some of the cattle will die.

Wenn die raben über ein haus fliegen und schreien, so stirbt eins aus demselben. Alem 19. 166

757. Wạmmer di junge sei im Lèb fun der lōs dut greische si wîscht. $(B e)$

If pigs are weaned in the sign of Leo they will squeal constantly.

758. Wạmmer fì schlạcht, dærf mers net dauere oders gēt lang net dōd. (Af)

If you pity an animal which is being slaughtered, it will die hard.

Wenn man ein vieh, das geschlachtet wird, beklaget, so kann es nicht ersterben. $G R 561$

759. Wạmmern gēs'bok hạlt ferdråğe di kì net. (Be, $B u$, Mt ; Freiburg)

A billy-goat on a farm prevents cows from miscarrying.

It is still a generally received opinion that a goat kept about an inn or farmstead is not only conducive to the health of the other domestic animals, but also brings good luck to the owner. Den 2. 75

760. Di schtell dærf mer net mischte ō̄eds noch sunnun'nergang oder mærğets fer sunnuf'gang, schunscht nemmt merm fî̀ 's glik. (Be,C,Lh, Lnc) Cattle will not thrive if their stalls are cleaned before sunrise or after sunset.

Man muss es vor sonnenaufgang und nach sonnenuntergang besorgen. Hlbg.

To clean a stable after dusk brings ill luck. $V S L 2.150$

761. Wạmmern schei'erschwạlm dōtmạcht gete di kì blūt'ichi mi'lich. $(B e, B u, D, L b, L h, L n c, N a, N u$, $S n, Y$ )

Kill a barn swallow and the cows will give bloody milk. 
Wenn man eine schwalbe tötet oder fort treibt, geben die kühe rote milch und man hat unglück mit dem vieh. $Z 744$

If a robin or swallow is killed the farmer will be punished with bloody milk from his cows. V S 2.203

762. Di kì gebe å rōti milich wạmmern grot dōtmacht. $(B e, B u, C, N a, S c, S n)$

The cows will also give bloody milk if you kill a toad.

763. Fì wært dærr oder grikt gēlwạsser wạmmers mit weide hakkt. ( $B e, B u, C, D, L b, L h, M r, N a, N u, S c$, $S n)$

If you strike cattle or horses with a willow wand they will emaciate or have œdema.

Das vieh soll nie mit einer weidenrute geschlagen werden. Alem 20. 282

Mit einem geschälten stecken schlage man weder vieh noch menschen, denn was damit geschlagen wird, muss verdorren. $G 3.416$.

764. Me kânlb schneit mer hōr fum schwanan a ab un fídert si der kū, nō blærrt si net. (Lnc, Nu)

A cow will not low if it is fed with the hair cut from the tip of the calf's tail.

Soll ein kalb entwöhnt werden, so schneidet man ihm ein büschel haare von der stirn und gibt es der kuh unter das fressen, so brüllt sie dem kalbe nicht nach. Wu 443 Hair cut off a calf's tail and put in the cow's ear makes her forget the calf when it is taken from her. $V S L$ 2. 401

765. Fun de hōr fum kâlb seinre schtærn ăbgeschnitte un der kū gfìdert mącht as di kū ken hēmwē grikt. $(D, L n c, N a, N u, S n, Y)$

A cow will not miss her calf if it is fed with a tuft of hair cut from the front of the calf's head.

Soll ein kalb entwöhnt werden, so schneidet man ihm ein büschel haare von der stirn und gibt es der kuh unter das fressen, so brüllt sie dem kalb nich nach. $W u 443$ 
766. Wǣr schwærze katze hot, hot glik mit de geil. (Be; Heidelberg)

Black eats bring luck to horses.

767. Freidåks soll mer ken geilschtell ausmischte. (Be, Lne, Sc, Y)

Horse stables must not be cleaned on Friday.

Am Freitag darf man nicht mist ausfahren. $W u 61$

768. Zwillingskelter fun ēn're sært zikt mer uf, ą巿er net wann si net alle zwẽ bul'lekelber oder a alle zwē kikelber sin. (Lh, Lnc, Mr, Sc, Y)

Raise twin ealves if they are both of the same sex, but not if they are of different sex.

Zwillingsvieh ist glückbringend und wird hoch bezahlt. $W u 434$

When twin calves are born they may be both perfect bull or perfect cow calves. When one is a bull calf and the other is a cow calf, the latter in general will not breed from malformation of the genital organs. $V S L 2.624$

769. Me låme gaul binnt mer hal bergaul ums be $\bar{e}^{-}$no gebts wider en ganzer gaul. (Bu; Freiburg)

Cure lameness in a horse by tying dock (Rumex crispus) round the lame leg.

770. Wạnn en kū der wolf im schwanz hot, schlitzt mern uf un dut sals un peffer nei $(A f)$ un rūs $(C, S c)$ un binnt der schwanz wider zī. (Freiburg)

If a cow has "wolf" in the tail, make an incision into the tail, put salt and pepper and soot in it, then bandage it up.

Worm in the tail is a sort of imaginary disease wonderfully common in horned cattle, to cure which the general fashion is to make in it a perpendicular incision near to the end, and to rub therein a composition of salt, soot, tar, turpentine and garlic, tightly enveloping all with a rag and cord. Den 2. 66 
771. Wạnn en kū der wi'derferkau ferlìrt hot si hōle hærner un der wolf im schwąnz. Nō bört mer en loch in jēder hærn un schtrïtzt fun îre ēğne milich nei . Wạnns hærn net blūt is si schlimm grank. Nō schlitzt mer der schwanz uf und dut sạlz, oder saln un peffer, oder rūs uf der schwanz un binnts zū. Nō macht mern balle fun holler oder fum gfusser wũ sich in willne glēder sammelt un schíbt en der hals nunner. Sell gebt re der t'drich. Oder mer schitt re salzwasser in di öre. $(A f)$

When a cow has indigestion, she has "hollow horns" and "wolf in the tail." Bore a hole into each horn and inject some of the cow's milk into it. If there is no bleeding, she is seriously sick. Lance the tail and put salt, or salt and pepper, or soot on the bony part of the tail, and bandage it. Make a ball of elder bark or of the fuzz which collects in woolen clothing and make her swallow it by pushing it down her throat. Or pour salt water into her ears. This will restore the cud, i. e. cure the indigestion.

772. Wạnn en kū der wi'derferkau ferlìrt, hot si hōle hærner un der wolf im schwanz. Nō bōrt mern loch in jēder hærn un schtritzt fun tre ēğne mi'lich nei . Wanns horn net blūt is si schlimm grank. Nō mạcht mern balle fun holler rinn un schîbts re der hạls nunner. (Af)

When a cow has indigestion it has "hollow horns" and "wolf in the tail." Bore a hole into each horn and inject some of the cow's milk into it. If there is no bleeding, the cow is seriously sick. Make a ball from the bark of the elder bush and push it down her throat. Bohre ein loch in das horn, das hohl ist, und melke von der nämlichen kuh milch und spritze sie in das horn. Dies ist die allerbeste kur für hohle kuhhörner. Hoh p. 36

773. Wạnn en schtik fi der t'drich ferlōre hot, schmtrt mern schtik butterbrōt un dut en zwi'bel druf. Sell schłbt mer nō der kū der hăls nunner. (Be) 
To cure indigestion in cattle, make an onion sandwich and push it down the cow's throat.

Der kuh gibt man nach dem kalben butterbrot, mit kreide und safran bestrichen, zu fressen, dann gibt sie gute milch. $W u 443$

774. Schtēl en schpillumbe un wi'kel en me låme gaul ums bẽ . $(C, D, M r, M t, S c, Y)$

Steal a dishcloth and tie it round the horse's lame leg.

775. Schtēl me weibsmensch der schærzbendel un binn en em gaul ums be $\bar{e}^{\sim}$ wā er ferrenkt hot. $(\mathrm{Be}, \mathrm{Na}, \mathrm{Y}$; Heidelberg)

Tie a stolen apron string round the sprained leg of the horse.

776. Me låme gaul binnt mern gschtōlner sa ${ }^{\prime} k$ bendel fume flaur'sak ums bē . (Be,Lb,Lh, $M r, N a, S c, S n)$

Tie a string, which has been stolen from a flour bag, round the leg of the lame horse.

Ein gestohlenes band vom mehlsack gilt für heilsam. $G$ 2. 952

777. Fìder de sei ho'lzkōle, nō bleibe si gsund. (Af)

Feed charcoal to pigs to keep them healthy.

[This is a direct survival of the old Germanic heathendom. Cf. Golther, Mythol. 575-6; also Alem. 20.283.]

778. Di seicher dut mer Sa'mschdåks fun der lōs, nō rollt si wider glei. ( $B e, D, L h, L n c, M t, N a, S n, Y)$

If pigs are weaned on Saturday the sow will come in heat sooner.

Donnerstags......Hlbg.

779. Wạnn leit geblōkt sin a a kelber zü frì kumme, gråbt mer ēns defu'n unner di schtânlldír, nō kumme si recht. $(B u, L h, L n c, S c)$

If you are troubled with calves being born too soon bury one under the stable door and they will come at the right time. 
780. Wạnn en kū der wi'derferkå ferlore hot gebt mer re sauerdēk. (Be, Lnc, Sc, Sn, Y; Heidelberg)

When a cow has indigestion feed it old fashioned yeast.

781. Ringbōn fergēt wammern leben'dichi grot druf binnt bis si dōd is. $(L n c, S c)$

Tie a live toad on a ringbone and keep it there till it dies.

782. Wạn en kū Mittwochs kạlbt dærf mers kalb net ufzíğe mitau's mer schneit em kalb en schtik fum ōr ab, schmeissts wek un såkt: dō, Mittwoch, hoscht dei ${ }^{\sim}$ sach. $(B e)$

A calf born on Wednesday must not be raised unless you cut off a piece of the calf's ear and throw it away, saying: here, Wednesday, is your share.

Die, die Mittwoche auf die welt kommen, bleiben nicht lange leben. Hlbg.

783. En bull dærf en kū juscht dreimol tschumpe, schunscht ferdråkt si. (Bu, Mt; Freiburg)

If a eow is covered more than three times she will abort.

784. Wạnn en kū fermạcht, schneit mer re di hōr ân der desch a b un schitt re si ei ${ }^{\sim}$, nō ferdråkt si nimmi. (Lh, Lnc, Sn, Y; Freiburg)

If a cow aborts, eut off her vaginal hair and give them to her internally.

785. Wąnn lōse nimmi rollich wærre solle, nåğelt mer en alter kupperner bens in der drōk. $(S n, Y)$

Nail an old copper penny into the pig's trough to prevent œstruation of the sows.

786. Schitt re schpî́liche lōs sēfich wąsser eĩ , sell schtopts. (Be, Lb, Lh, Na,Sn)

To stop ostrus in a sow give it some soapy water.

787. Năğel de sei kupper in der drōk, no wærre si net rollich. $(C, S c, S n)$

Copper nailed in the pig's trough will prevent æestruation. 
788. Wạnn en lōs schpìlich wært, schitt re 's sēfewąsser fum balibire un di hōr as mer sich im baltbtre ąbschneit ei ${ }^{\sim}$, oder mer gebts re im saufe. $(A f)$ When a sow comes in cstrum give it the soapy water and the lather after shaving, either directly or in its food.

789. Sõ ạs en sau nimmi rollt duscht pår schrōt mit re hollerflint dærich di fotz in der dråksakk. $(C, L h$, $S c)$

To prevent estration in sows insert, by means of a elder popgun, several shot per vaginam into the uterus.

790. Sō ạs en lōs nimmi rollt dut mer pår schrōt in îr dråksakk mit re hollerflint. (C, Lh, Sc, $Y$; Heidelberg) To prevent œstruation in sows insert, by means of a blowgun made of elder wood, a few shot into its uterus.

791. Me gaul en ku'metblōder zu ferdreibe, wærm di hand an deim gemech un schtreich di blōder nō mit sellre hạnd. (Be)

To cure collargall warm your hand on your exterior genitals and with that hand rub the sore.

792. Fer kumetblōder am gaul. Der mann as schtri'ğelt soll sei ${ }^{\sim}$ hand an seim sekel wærme un si nō uf di kumetblōder hēbe bis si ąb'gekilt is. Des muss er drei mærğe hinnich nạnner nō dũ . (Be,Lh, Lnc, $\mathrm{Na}, \mathrm{Sc}$ )

To cure collargall. The man who curries the horse should warm his hand on his penis and hold it on the collar gall until the hand has cooled off. This should be done three mornings in succession.

793. Wạnn en gaul en ku'metblōder hot, reib si mit deim ẽğne geme'ch. (Be, Lh, Lnc, Mt, Na, Sc; Kaiserslautern)

Cure collargall in horses by rubbing your privates on it.

794. Wạnn en gelser um'gang kạt hot mit seinre frå ferre'kt em ąlles às er schneit der nēkscht dåk. (Be, Lh, Mr, Mt; Heidelberg) 
If a gelder had intercourse with his wife, every animal that he unsexes next day will die.

795. Schitt me gaul as gfaun'dert is me weibsmensch ir blitz ei . (C,Sc; Kaiserslautern)

To cure founder in a horse give it human menstrual discharges.

796. Fìdre kū âs net drå'ğend bleibt du'libūne bletter. (Bu; Heidelberg)

If a cow does not stay fertile, feed her tulip leaves (Tulipa Gesneriana).

797. Wạnn en kū sich net butze kannn noch 'm kąlbe, muss mer re brōt fìdre. $(B e, L h)$

If a cow retains the afterbirth feed her some bread.

Wenn eine kuh sich nach dem kalben nicht reinigen kann, so gibt man ihr sieben nuszsättel und brot. Wu 443

798. Wạnn en kū net dråğich bleibt fîdert mer re di schåle fun aus'gebrite oier. (Be,Lh,Lnc, $M t, N a, S c$; Heidelberg)

If a cow does not stay fertile feed her the shells of incubated eggs.

799. Wănn en gaul gfaun'dert is, nemm en frischer menschedrek, wikel en in en willner lumbe un dūn um gaul sei ${ }^{\sim}$ gebi'ss. ( $\left.A f\right)$

To cure founder (laminitis) wrap human feces in a woolen rag and tie it to the horse's bit.

Wider die rehe, nimm dem pferd seinen zaum und ziehe das gebiss durch menschenkot, zaume das pferd damit auf und hebe ihm die nasenlöcher zu bis er niesen muss. Ho p. 85 ; cf. Alem 20.282

800. Wąnn en kū dik is schmîrt mern schtrō'sēl mit dær un schtbts der kū ins maul. ( $A f)$

Cover a strawband with tar and force it into the cow's mouth, to cure her of tympanitis. 
Um der aufblähung des viehes vom klee zu helfen, nimmt man ein strohseil und taucht den knopf davon in teer und steckt dem kranken vieh den geteerten knopf ins maul und bindet das seil hinter den hörnern zusammen. Ho p. 129 ; cf. $Z$ f $D M 4.116$

801. Wạnn en kū ferdråkt fergråbt mers kă lb aus'ewennich âm kìschtâll ă der dîr un'ich der dạchdrạps wū di kì driber låfe misse. ( $B e, B u, L h, L n c, M t, N a, S c$, $S n, Y$ )

When a cow aborts bury the dead-born calf under the barn eaves just outside the cow stable door.

Dies crepierte bald, es wurde unter der stalltüre vergraben, und der viehfall unterblieb von da an. $J G A 3.15$.

Wenn dem bauer ein füllen oder kalb zu wiederholten malen fällt, so vergräbt ers im garten. $G 3.838$

Ein totenkopf im pferdestall vergraben gibt den pferden gedeihen. $G 3.815$

The untimely calf is carefully buried beneath the threshold of the cow-byre, the admitted object being to avert a like disaster. $C F Y 2.68$

802. Fer rē'ichkēt, bruns me gaul ufs fūder. ( $\mathrm{Be}, \mathrm{Na}, \mathrm{Sc}$, $Y)$

To cure founder from overfeeding urinate on the horse's fodder.

Wenn ein pferd zur rehe ist, so schneide man dem pferde von allen vier füssen kreuzweise von den warzen, die es inwendig unter den knien hat, tue es zusammen in deinem urin und giesse ihm solches in die ohren. Ho p. 86

803. Wạnn en gaul di ko'lik hot oders wansser net mạche kann, loss en kel'lerēsel em gaul der bibs nufgrâdle. $(B u)$

To cure colic or retention of urine in a horse, let a woodlouse crawl up the horse's sheath.

Wenn ein pferd nicht stallen kann, nimm drei läuse von einem knaben, der unter 7 jahren alt ist, und stecke sie dem pferde in den schlauch. Ho p. 84 
804. Reib schpåte âme gaul mit me gannze gnoche. ( $A f)$

Rub the spavined leg of a horse with a whole bone.

$\mathrm{Du}$ nimmst einen knochen, wo du ihn findest, darfst ihn aber nicht suchen, und reibst damit dem pferde das gewächs; es muss aber in abnehmenden licht geschehen. Das gewächs wird alsdann gewiss vergehen. Lege aber den knochen wieder, wie er gelegen. Hoh p. 38

805. Wann en kū dik is schitt re mischtbrî eĩ. ( $L a, N a$, $S c, Y)$

To cure tympanitis in a cow give it manure drainings.

Einige nehmen 1 peint starkes mistwasser und schütten solches dem aufgeblähten vieh ein. Ho p. 129

806. Wạnn en kū dik is schtecht mer si. (Be, $L h, M t)$ Puncture a bloated cow, i. e., if she has tympanitis.

In den wannst stechen ist das sicherste mittel für aufblähung. Ho p. 130

807. Fer hîts ame gaul, schitt em wạsser ei ${ }^{\sim}$ fun wesch a s fun der blitz fersaut is. $(S c, Y)$

Give a heavy horse water in which menstruous cloths have been washed.

Für rehe ross oder rindvieh : nimm ein hemd oder leilach von einer frau an, welche ihre monatliche zeit hat, leg' selbiges ins frische wasser, lass selbiges von dem wasser trinken. $A M 1.18$

808. En kū brillt net fer îr kạlb wąmmer fum kalb seine hōr åm schwannz ånschneit un binnt si der kū in di kett. $(B u)$

Dock the calf's tail and tie it into the cow's chain to prevent the cow from lowing for her ealf.

809. Schneid em kạlb di hōrwærøel ạb uf em greitz, fanne uf em bu'kel uf de schuldre, un zwische de öre un fłder si der kū nō brillt si net fer îr kąlb. (Lh, Lnc, $N u, S c, S n, Y)$

Cut the cowlicks from the calf's spine, shoulder blades and between the ears; feed them to the cow to prevent homesickness for the calf. 
Verkauft man ein kalb, soll man demselben mit einem wisch haar über den rücken hinabfahren, diesen wisch der kuh zu fressen geben, so bekommt sie keine langweil nach dem kalb. VAS 1.121

810. Wạmmern kạlb hin'nerschich di dîr naus dut un såkt: ich geb dern sent sō a as der dei mutter net nō blærrt, dut si å net. $(B e, L h, M r, S c)$

A cow will not low for its calf if when backing the calf out of the stable you say: I'll give you a cent, so that your mother will not become homesick for you.

Man gibt dem kalb gekautes brot und spricht: "hier, kalb, ist dein futter, vergiss deine mutter." Wu 443

811. Kåfte sei dut mer hin'nerschich in der schtąll. (Be, $C, L h, L n c, N a, N u, S c, S n, Y$ )

Newly purchased pigs should be backed into the sty.

Die schweine werden beim kaufe rückwärts in den sack gesteckt. Alem 20. 283

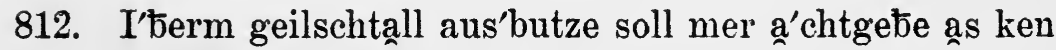
schpin'newēb in der geilsdrōk falle schunscht fergifts di geil. (Be,Lh, Lnc, Mt; Nürdingen)

In cleaning the horse stable take care that no cobwebs fall into the manger, for it will poison the horses.

813. Wănn di kì ken milich gebe, schtēt mer mær'ğgets uf, schwetzt nix, gēt naus in der kischtall, melkt di kł un schitt di milich nō ins bríbi $(L h)$, ins feier $(L b)$. No geђ̄e di kì wider milich.

If the flow of milk in cows is scant, get up early and before having spoken a word to any one milk the cows and pour the milk into the privy or fire.

Ist die milch blau, giesst man sie mehrmals in den abort; sie wird dann für die hexen nutzlos und diese dadurch vertrieben. Alem 20. 283

814. En Mittwochskąlb ztkt mer juscht sō gūt net uf, 's gebt en'ihau nix draus. ( $B e, C, D, L h, M r, N a, S c$, $S n, Y)$ 
Calves born on Wednesday should not be raised, they won't turn out well.

Kälber, die an einem Nittwoch geboren werden, sollen schnell $z u$ grunde gehen. $Z f D M$ 1. 238; Alem. 20. $282 ; G 3.127$

815. Wạmmere kū 's kąlb nemmt muss mer der schærz un'ich di dtr schmeise, nō grikt si 's hēmwē net. $(B e, B u, L h)$

When taking the ealf from the cow, throw an apron over the sill of the stable door and the cow will not become homesick for its calf.

Man breitet in Baden einen schurz auf den boden, führt die kuh hinüber, wenn sie heimweh nach ihrem früheren stalle hat. $M D V 213$

816. 'S kâlb muss mer hin'nerschich di dìr naus dū $\sim$ un in ēm o'chtem, nō blærrt di kū net. ( $A f)$

If you back the calf out of the stable while holding your breath, the cow will not low for its calf.

Die kuh wird schweigend und mit zurückgehaltenem atem in den stall geführt, so schreit sie dann nicht. $W u 439$

817. Wămmern kâlb ån'gewēne will, dut mers hin'nerschich zu der dîr naus, nō brillt di kū net. $(A f)$

When ready to wean a calf, back it out of the stable and the cow will not low for it.

818. Wạmmern kạlb ferkåft muss mers hin'nerschich di dîr naus dū , nō brillt di kū net. $(A f)$

The calf which has been sold should be backed out of the stable, so that the cow will not low for it.

Verkauft man ein kalb, so zieht man es verkehrt aus dem stall. M $D V 213$

819. Mer henkt me kânlb sei halsband der kū ins ref, nō blærrt di kū net wămmers kąlb ferkåft. ( $B e, B u$, $D, L n c, M r, M t, N a, S c, S n, Y$; Heidelberg)

If you hang the calf's collar on the hay rack in the cow stable the cow will not low for its calf. 
820. Wạmmers kạlb ferkåft, binnt merm kąlb sei hălsbănd der kū in di kett, no grikt di kūs hēmwē net. $(L h, L n c, M t, Y)$

If the calf's collar is fastened to the cow's chain the cow will not be homesick for its calf.

Verkauft man ein kalb, so zieht man es verkehrt aus dem stall und wickelt dessen strick der mutter zur tröstung um die hörner. $M D V 213$

821. Wạmmern neii kū grikt soll mer re fun de bąngs ấbschneide, di zottle fume schptllumbe ferschneide, un des nō all in re pannn mixe uns di kū nō aus der pann fresse losse, nō grikt si ken hēmwē. (Lnc, Sn, Y; Ettlingen)

Cut off the foretop of the newly purchased cow, cut up the shreds of a dishcloth, put all into a pan and mix it. Let the cow eat this and she will not become homesick.

822. Bi'sskạtzegraut is gūt fer leis. (Mr, Sc; Kaiserslautern)

Skunkcabbage (symplocarpus foetidus) is a good remedy for lice.

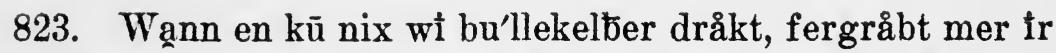
butzich (oder butzing) an en ańb'belbåm, so grikt si kì kelber. $(L h, S c)$

If a cow drops nothing but bull calves, bury the afterbirth under an apple-tree and she will bear heifer calves.

Dass eine kuh kein stier- sondern ein kuhkilb bringt, nimm ihre reinigung, wenn sie kälbert, und grabe sie unter einen apfelbaum, so trägt sie ein kuhkalb. $A M$ 1. $14 ; B M 19$

824. Wạn en rind en kallb grikt reibscht em rind di butz dreimol i'bers greitz, nō schlakkts net wánmers melkt. ( $B e, L h, M t, S n)$

When a heifer drops its first calf, rub the placenta threo times over the heifer's spine and it will never kick during milking. 
825. Wąnn en kū blü'tichi mi'lich gebt schitt mer si in en schtåkeloch un schtekt der schtåke nõ wider ąn sei ${ }^{-}$ blatz. (Be, Lnc, Sn; Lustnau)

If a cow gives bloody milk, pull out one of the cross stakes of a worm fence, pour the milk into it and replace the stake.

826. Wạnnd en kū kåfscht lēk der schtok $(C, N a, S c)$ oder èn'ichi wip $(D, S c, S n)$ wūd di kū gedri'be hoscht mit in'newennich an di dín reschwell un loss di kū drìber låfe, nō grikt si ders hēmwē net.

Place the stick or the whip, with which you drove your newly purchased cow, inside the door along the sill, and your cow will not be homesick.

Ein stecken wird quer über den eingang gelegt, so dass der ochs über diesen hinwegschreiten muss. Alem 8. 125

827. Di nei kū grikts hēmwē net wănnd en schtē ${ }^{-}$mit'nemmscht wūd si kåft hoscht un en der kū in der drōk schmeischt. (C, Lnc, Mt, Sc, Sn)

A cow will not be homesick if you take with you a stone from the place where you bought the cow and place it in the manger.

828. Wạnnd en kū kåfscht, musscht der schtok wūd si gdribe hoscht mit, hinnich di kū schtelle, no grikt di kū 's hēmwẽ net. ( $B e, D, L b, L h, M r, N a, S c, Y)$

A cow will not become homesick if you place the stick, with which you drove the cow, behind her.

829. Henk en hunnskopp in der kischtânll, nō ferdråğe di kì net. $(M t)$

To prevent abortion in cows, hang a dog's skull in the cow stable.

830. Di ki ferdråğe net wạmmern rin'nsggąll in der ktschtall henkt. ( $B e, L h, M r, M t, N a, N u, S c, Y$; Heidelberg)

Cows will not abort if a bovine gallsac is hung in the cow stable. 
831. Reib en ku'metblōder mit me schtễ un fergråt en nō in flisend wassser. (D, Lh, Sc, Sn; Kaiserslautern) Rub a collargall with a stone and bury the stone in the bed of a stream.

832. Wạnn en kū ferdrå’kt năğelt mern a alter kupperner sent in der drōk. (Be, D. Lnc, Y)

If a cow aborts, nail an old copper penny into its trough. Altes eisen an den trog gehängt. . . . H Hlbg.

833. Dū'taks ribbe in der sei'schtall gedū ${ }^{\sim}$ ferdreibe seileis. ( $M t, S n, Y$; Heidelberg)

Ribs of tobacco, placed in the pigsty, will drive out lice.

834. Săs'sefras ferdreibt di leis im seischtanll. $(C, D, N a$, $\mathrm{Nu}, \mathrm{Sc}, \mathrm{Sn})$

Sassafras (Sassafras officinalis) will drive out lice in the pigsty.

835. Wollebletter in der seischtall kenkt ferdreibe seileis. $B e, B u, M r, M t, S n)$

Put mullein leaves (Verbascum thapsus) into the pigsty to drive out lice.

836. Wạmmern kạlb å binnt muss mer såğe: Dō, Kunschåø’ler, sauf. ( $(L b, L h, M r, N a)$

When you wean a calf, say: Here, constable, drink.

Der anbindende soll selbst dabei trinken, wenn das kalb angebunden wird. Swab

837. Wann en kū 's milichfíter hot wescht mer sich di hend mit tre milich un nō schtreicht mer di kū der lange wēk âm leib naus gråd fum eider wek. $(B e, B u, L h$, Lnc, $\mathrm{Mt}, \mathrm{Na}, \mathrm{Sn}, \mathrm{Y}$; Heidelberg)

To cure garget, wash your hands with the cow's milk and then pass the hand along its belly, starting from the udder.

838. Wann en schtik fì uf di welt kummt soll merm en schtik fun seim ơr a abschneide un såğe: dó, Mittwoch, hoscht dei ${ }^{\sim}$ sach. $(L b, L h, M t, S c)$ 
Cut off a part of the ear of a calf born on Wednesday and throw it away, saying: "Here, Wednesday, take your share."

Was Mittwochs auf die welt kommt, ist nichts nutz. Hlbg.

839. Wạnmer ærğets seicher hōlt muss mer recht schtærik fåre un net unnerwe'ks schtope, no schtope di seicher net wåxe. ( $B e, L h, L n c, S c)$

When fetching shoats from any place, drive very fast and do not stop on the way, so that the growth of the (little) pigs will not be interrupted.

Man soll nicht stark fahren. Hlbg.

840. Wạmmer sei Sạmschdåks hōlt hot mer ken glik mit. (C)

If you fetch pigs on Saturday they will not thrive.

841. Wạmmer di kì 's èrschtmol in di wēt dut, såkt mer: "fress net wì en wolf," nō wærre si net dik. (Be, $B u, L b, L h, M r, N a, S c$; Kaiserslautern)

To prevent cows from having tympanitis when taken to pasture for the first time, you should say: do not eat like a wolf.

842. Fern gschwolle eider, weschs mit tē a as fun junge weide gemacht is. (Lnc, Sn)

Reduce the swelling of the udder by bathing it with tea made of willow shoots.

......von allerhand wiesenkräuter. Hlbg.

843. Junge schōf dut mer Sunndåks fum mu'tterschōf, no gebts jung schōf wider en mutterschōf. ( $\mathrm{Na} ; \mathrm{Hei}$ delberg)

If lambs are weaned on Sunday they will become broodewes.

844. Disem'ber sei bleibe gle un grutzich. ( $B e, D, L h, S c$; Heidelberg)

Pigs born in December will not grow large. 
845. Wạmmer ærğets junge sei hōlt un schtopt uf em hēmwēk gèt ēns defu'n dod. (Be,Lh,Lnc, $M r, N a, S c$, $S n$; Heidelberg)

When fetching shoats never stop on the way home, one of them is sure to die if you do.

846. Fìdre kū as der ì'drich ferlöre hot 's gfusser in glēder. ( C, Na, Sc; Kaiserslautern)

To cure indigestion in a cow feed it the fuzz collected in clothes.

847. Wann en kū der t'drich ferlōre hot, fì'derscht re sauergraut oder mąkrel. (C, Na, Sc; Freiburg)

To cure indigestion in a cow give her some mackerel or sauerkraut. 


\section{MILK AND BUTTER}

848. Wănnde butter drēscht, drē juscht $\tilde{e}^{-}$wēk schunscht drēscht en wider uf. (Af; Heidelberg)

When making butter, turn the erank in only one direction, or you will undo it.

849. Wạmmer a am butter drēe is un er will net zạmme $\mathrm{ge}^{\sim}$, soll mer såğe: Butter, butter, butter dich, 'S is ken aer'ğeri hex wt ich. $(B u, D, L b, L h, L n c, M t, N a$, $N u, S c)$

If butter is slow in coming, say:

Butter, butter, come,

There's no greater witch than I.

Come, butter, come,

Come, butter, come,

Peter's waiting at the gate

Waiting for a buttered cake.

Come, butter, come. $H 67$

850. Wąmmer butter drēt, soll mer såğe: "butter, butter, grimmel dich," nō get er gschwinder zanme. (Be, $B u, L h, L n c, M t, N u, S c$; Heidelberg)

When churning butter, it will come sooner if you say: butter, butter, come.

851. Wann der butter net zåmme gẽ ${ }^{\sim}$ will, soll mern butschermesser nei renne. (Be, D, Lb, Lh, Lnc, Na, $S c, S n, Y)$

If butter won't come, jab the milk with a butcher knife. Ein weib, das butter rühren will, soll ein dreikreuziges messer ans fass stecken, so gerät die butter. $G$ 3. 70

852. Wạnn di mil'ich ferhext is as mer ken butter drēe kănn, soll mer mit em mi'schthōke nei gẽ ${ }^{\sim}$. $(B e)$ If milk is bewitched so that butter won't come in churning, put the dung hook into the milk. 
Man macht die mistgabel glühend und träufelt etwas von der milch aus dem fass kreuzweise darauf und steckt die glühende gabel ins fass, nimmt sie dann heraus und buttert, alles aber schweigend, so kommt die hexe und bittet um einlass. $W u 449$

853. Wạnn di hexe im butterfasss sin soll mern glídich eise nei ${ }^{\sim} \bar{u} \sim$, sell dreibt si aus. $(B e, C, D, L b, L h, N a$, $S c)$

If the butter won't come, the milk is bewitched. To drive out the witches, put red hot iron into the churn.

Wenn beim buttermachen die milch lange nicht bricht, nehme man einen küchelspiess, mache ihn glühend und stosse ihn in den butterkübel. Geschieht das, wird die hexe damit gebrannt und die milch bricht. $Z 554$

At the present day the good housewife puts a hot iron into the cream during the process of churning to expel the witch from the churn. $D Y 170$

854. Wann di mil'ich ferhext is muss mer di flint låde mit silbergeld an'schtatt schrōt un nō in di milich schisse. $(B e, L h, S c)$

Shoot a charge of silver coin instead of shot into bewitched milk and the witch will disappear.

Eine hexe kann man nur verwunden, wenn man mit einem stück erbsilber oder einem geldstück schiesst. $W u 160$ Silver is always considered an antidote against witcheraft. $C F N u 4.54$

855. Wann di mil'ich ferhext is muss mer si ferschneide un ins feier schitte un ferbrenne. ( $B e, B u, C, D, L b$, $L h, M r, N u, S c, S n$ )

Cut bewitched milk with a knife, pour it into the fire and burn it.

Sind kühe und milch behext, so sticht und hackt man mit messern, gabeln usw. in die milch. $W u 284$

856. Ferhexti mil'ich schlakt mer mit weisdærne, sell schlecht di hexe raus. $(B e)$

Drive witches out of milk by beating it with hawthorn.

Man hackt sie mit der sichel. $K l$ 
857. Wąnn di hexe im butterfąss sin schtsst mer nei- mit der schrötflint. (Be, Lnc, Na; Kaiserslautern)

When witches infest the churn shoot into it with a shotgun.

858. Wann di mil'ich ferhext is dut mer si in en pannn uf der ofe un schtecht nei $\sim$, nō gēt di hex raus. $(\mathrm{C}, \mathrm{Na})$ Put bewitched milk into a pan, set it on the stove and thrust a knife or fork into it.

Rote milch einer behexten kuh muss kochend mit ruten gepeitscht werden. Der schmerz zwingt die hexe sich zu melden und die kuh zu heilen. G 3.540

859. En kū wū blūt'ichi mil'ich gebt is ferhext. (Af)

Bloody milk indicates a bewitched cow.

Rote milch einer behexten kuh muss kochend mit ruten gepeitscht werden. G 3.540

860. Wămmer der butter net zạmmedrēe kann, sin di hexe drin. $(A f)$

If the butter will not churn, the cream is bewitched.

Wenn man die butter nicht zusammen bringt, sind die hexen darin. $Z 325$

If a witchwoman overlooks the churn the butter will be carried off to her own churn, though she has nothing but water in it. $W \operatorname{Ir} 50$

861. Wann di mil'ich ferhext is soll mern gltdich eise nei dū . (Be, C, D, Lb, Lh, Lnc, $N a, S c)$

Thrust red-hot iron into bewitched milk.

Wenn beim buttermachen die milch lange nicht bricht, nehme man einen küchelspiess, mache ihn glühend und stosse ihn in den butterkübel. Geschieht das, wird die hexe damit gebrannt und die milch bricht. $Z 554$

At the present day the good housewife puts a hot iron into the cream during the process of churning to expel the witch from the churn. $D Y 170$ 


\section{POULTRY AND EGGS}

862. Mit Kærfreidåks oier kạmmer güt brauche (Be, $C, L b, L h, M r, N u, S c, \hat{Y}$ )

Eggs laid on Good Friday are used in powwowing.

Eier, welche von schwarzen hennen am Karfreitag gelegt werden, behält man fleissig auf; denn sie sollen in ver. schiedenen dingen wunderbare wirkung haben. $V A S$ 2. $78 ; W u 71$

An egg laid on Good Friday is preserved as a charm. V S L 2.1. 224

863. Kærfreidåks oier faule net. (Be, C, $L b, L h, M r, M t$, $N u, S c, Y)$

Eggs laid on Good Friday will not decay. Karfreitagseier faulen nicht. $W u 74$

864. Mer dærf net mit der hand in en gin'ihinkelnescht lănge oder di gin'ihinkel gēn nimmi ufs nescht. ( $B e$, $B u, L b, L h, L n c, M t, S c, S n, Y$; Heidelberg)

If you touch the nest of a guinea hen with your hand, it will abandon its nest.

865. Oier ăs mer middåks um zwelf ūr ( $B e, N a, S c, S n, Y)$ oder mærğets fer de sexe $(C)$ setzt gebe lauder hinkel.

If you set a hen at high noon or before $6 \mathrm{~A}$. M. hen chicks will be hatched.

Eier legt man zum brüten hin in der mittagszeit, meist 13, und wünscht in einem spruche: zwölf hühner und einen hahn. $W u 429$

866. De brt'iche hinkel binnt mern rōter bendel ån der schwañz. $(\mathrm{Na})$

Tie a red string about the tails of broody hens.

867. Di brthinkel schtekt mer unner wąsser, sell schtopt ne ir brte. (C, Mt, Na, Sc; Heidelberg)

Broody hens should be ducked. 
868. Wąnn hinkel net uf'gete wolle brte, fårt mer si uf em schub'kærich rum. (Lh; Lustnau)

Haul broody hens on a wheelbarrow.

869. Di oierschåle soll mer immer ferbrenne sō ấ di hinkel 's oierfresse net lærne. (D, Lb, Lh; Heidelberg)

Egg shells should be burned so as to prevent hens from acquiring the habit of eating their own eggs.

870. Aus oier wū uf der Kærfrei'dåk gelēkt sin gebts schek'iche hinkel. (Lh, Lnc, $\mathrm{Na})$

Chickens hatched from eggs laid on Good Friday will be speckled.

Hühnereier vom Karfreitag geben hühner, die jährlich die farbe ändern. $W u 74$

871. Wammer di oier setzt ąs uf der Grĩdun'nerschdåk gelēkt sin gebts lauter schek'iche hinkel. $(B e, C$, $L h, L n c, M r, M t, N a, S c, S n)$

Chickens hatched from eggs laid on Maundy Thursday will be speckled.

Hühner aus Gründonnerstags gelegten eiern gebrutet ändern alle jahr ihre farbe. $G$ 3. 344

872. Di Grischdåknącht schpannt mern schtrik so weit ąs di hinkel rumlåfe, no hōle di woi ken hinkel. $(C$, $L h, L n c, Y)$

If on Christmas night you stretch a rope to as far as the chickens roam, hawks will not prey on them.

In der Christtagnacht steckt man eine dünggabel auf den mist, dann verliert sich kein huhn. Lust

873. Oier as mer setze will muss mer sō rū'ich hendle ås mēğlich. (Af; Heidelberg)

Eggs for setting should be handled as gently as possible.

874. Wănmer drei særte frucht di Grischdåknącht nausschtellt un ftdert si nō de hinkel de Grischdåk- un Neijőrmærğe, kannn ken woi selli hinkel grtğe. (Be, Lh, Sc; Heidelberg) 
Hawks will not catch the chickens which were fed on Christmas and New Year's mornings with three kinds of grain which had been set out on Christmas night.

875. Welschkannn ei ${ }^{\prime}$ gewēcht in fett wū fåsenąchtkuche drin gebake sin wærre fídert mer de welschhinkel, no gēn si net fært îr oier zu lēğe. ( $(L h, L n c, M r, N a)$ Turkey hens will not lay their eggs away from home if they are fed with corn which has been soaked in the lard in which doughnuts were baked.

Willst du glück mit den hennen haben, $d$. h. so dass sie dir nicht verlaufen, so gibt man ihnen ein in schmalz geröstetes brot; desgleichen tue neu angekauften hennen; sie bleiben. $A S 1.400$

876. En ungliksoi schmeisst mer hin'nerschich i'torn dạch; nō gēts unglik mit fært. $(A f)$

Throw a dwarf egg backwards over a building and the bad luck will accompany the egg.

Auffallend kleine hühnereier, sogenannte unglückseier, müssen "hinterschtöwerscht" $d$. h. nach hinten über's dach geworfen werden. Alem 20. 284

877. En ungliksoi muss mer i'Ђern dạch schmeisse, oder mer hot ken glik. $(A f)$

It is lucky to throw a dwarf egg over a barn.

Wenn eine henne zwergeilein legt, soll man sie übers dach werfen. Bringt man's hinaus, so hat man glück; wenn nicht, so unglück. $V A S 1.125$

878. Wạnns frì gewittre gebt sin di gens gūt ufzł̆ge. $(B \varepsilon$, $Y$ )

If there are thunderstorms early in spring, it is an easy matter to raise geese.

Wenn es am Palmsonntag regnet, gedeihen die jungen gänse nicht. $W u 73$

879. Wạn di oier $\mathfrak{x}^{\prime}$ rik wol'fel sin bezålts de hinkel net ąs si î årschlecher auswëre. (Be, Bu,C, D, Lnc, $M r$, $M t, N a, S c, S n, Y$; Heidelberg) 
When eggs are very cheap it doesn't pay a hen to wear out its cloaca.

880. Wămmer oier setzt dærf mer net âm disch defu'n schwetze schunscht kumme si net gūt raus. $(B e, C$, $D, L b, L h, M t, S c ;$ Heidelberg)

Do not discuss the setting of hens at meal time, the eggs won't hateh.

881. Gluke setzt mer zwische elfe un zwelfe. $(C, S c)$

Hens should be set between eleven and twelve.

Will man eine henne setzen, so muss dies an einem Freitag mittags um 11 uhr geschehen. VAS 1. 473

882. Wąmmer di gluke fạm'midåks setzt kumme di junge en dåk oder zwē frìter raus. $(D, M r, S c)$

Chickens will hatch a day or two sooner if the hens are set during the forenoon.

883. Hinkel setzt mer Sunndåks zwi'schich elfe un zwelfe wann der pa्arre der sēğe schprecht, nō kumme si gūt raus. $(\mathrm{Be}, \mathrm{Lh}, \mathrm{Mr}, \mathrm{Na})$

To insure a good hatch, set hens on Sunday between eleven and twelve when the benediction is pronounced in church.

Eine henne setze man brüten, während die leute aus der kirche gehen, dann kriechen viele jünge aus. $G 3.18$

884. Hinkel setzt mer in der Jungfrå, nō kumme si gūt raus. (Lh, Lnc, $N a, N u, S c, S n, Y$; Heidelberg)

If hens are set in the sign of Virgo the eggs will hatch well.

885. En gluk setzt mer mit re ungråde nummer oier. (Af)

Set a hen on an odd number of eggs.

Einer bruthenne legt man eine ungerade zahl eier unter. Alem 27. 241

Hens should sit on an odd number of eggs and not always alike. $V S L 2.14$

886. Wạnn em en hinkel dōd gēt, muss mers ỉ̄er di lein dråğe, nō gēt kens mē dōd. ( $B e, L b, L h, M t, S n, Y)$ Carry a dead chicken beyond the confines of your own premises to prevent others from dying. 
Wenn früher den leuten mehrere stück vieh hinter einander tot blieben, dann brachten sie ein totes stück über die grenze des dorfes und banden es an einen busch fest. Dann starb ihnen kein vieh mehr. $B S 33.170$

The animal which had died of plague or some other serious disorder was carried at night to a neighboring proprietor's land and buried. $B$ F 47

887. Hinkel a as im Moi rauskumme grìge Moischtągger. (Lnc)

Chickens hatched in May will have staggers, i. e. will not thrive.

Sie sin nix nutz. Hlbg.

Eggs should not be placed below a hen for hatching during the month of May. Hence the saying: May chickens is aye cheepin. $G S \operatorname{sot} 141$

888. Dēl leit hēbe Kærfreidåksoier uf fun ēm jōr zum ąn'nere. Si sin gūt fer brauche mit. $(B e, B u, L b, L h$, $M r, M t, S c, S n, Y$; Heidelberg)

Some persons keep eggs laid on Good Friday from one year to the next. They are used in powwowing.

889. Wămmern brî hinkel setzt, muss en weibsmensch di oier im schærz naus dråğe fer setze. ( $A f)$

Eggs will hatch better if carried to the stable by a woman in her apron.

To secure hen birds the woman who sets the hen should carry the eggs in her chemise to the hatching nest. $G$ Scot 141

890. Schpitz'iche oier geந̄e håne, runde hinkel. (Be,Bu, $C, L h, L n c, M t, N a, S c, S n, Y$ )

Cocks will be hatched from pointed eggs, hens from round ones.

Runden eiern entschlüpfen bühner, spitzen hähne. Alem 20. $284 ; Z 695$

Short hen-eggs produce female birds; the long eggs, male birds. $G S \operatorname{scot} 141$ 
891. Wann en dotter en brokl drek hot gebt sell oi en håne. ( $L b, Y$; Heidelberg)

A speck of dirt on the yolk of the egg shows that a male chick will be hatched from it.

892. Wạnn en hinkel grēt mạchs gråd dōd. (Be, Lnc; Heidelberg)

Crowing hens should be killed at once.

893. Eb mer oierschåle wekschmeisst soll mer si ferdri'ke, schunscht nemme di hexe si fern bōt. ( $B e, C, L h$, Lnc, Mr, Sc; Heidelberg)

Egg shells should be crushed before they are thrown away, else the witches will use them as boats.

People ought to remember that egg shells are favorite retreats of the fairies, therefore the judicious eater should always break the shell after use to prevent the fairy sprite from taking up his lodgment therein. Ir 2. 102

894. Di oierschåle muss mer ferbreche, sō ạs di hexe si net jü'se kenne. (Be,C,Lnc, Sc; Heidelberg)

Egg shells should be broken up, so that witches can't use them.

895. Wammer di oier im schærz nausdråkt fer setze gebts

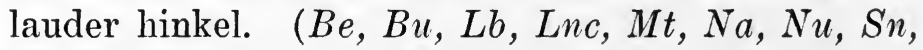
$Y$; Heidelberg)

If a setting of eggs is carried to the nest in an apron you may expect nothing but pullets.

896. Mer soll ken hinkel setze sō as di junge rauskumme im Tschūlei'. (Mr; Heidelberg)

A chicken in July is not worth a fly. (Mt)

897. Wạnn di hinkel net lēğe wolle tạkscht en sein im hinkelschtâll uf "oier zēe sents dutzend," nō lēğe si giwiss. (Bu)

When hens don't lay tack up a sign "Eggs, 10 cts. a dozen," and they will certainly begin to lay. 
898. Wămmer ōschter oier im haus halt iøers jōr schtærbt ēns aus der familie. (Lnc, $\mathrm{Nu}$; Kaiserslautern)

If Easter eggs are kept for more than a year some one in the family will die.

899. Oier ås mer setze will dærf mer net iber wassser dråğe oder si kumme net raus. (Be, $D, L n c, S n, Y$; Heidelberg)

If eggs are carried over a stream they won't hatch.

900. En mannskærl muss di oier fer setze ime weibshūt nausdråğe, wanns hinkel gebe soll. (Be,Lb,Lh, Lnc, $M t, N a, S n, Y$ )

To secure hen-birds, the hen should be set with eggs carried in a woman's bonnet by a man.

Wer eine bruthenne setzt und küchlein mit hauben erzielen möchte, setzt selbst eine haube oder einen hut auf den kopf. $B M 17$

901. Wạnn en mạnnskærl di oier im hūt nausdråkt fer setze gebts håne. (Be, Lb, Lnc, Na, Y)

If the eggs for hatching are carried by a man in his hat, only male birds will be hatched.

Ein mann darf keine bruthenne setzen. Hlbg.

902. Wạnn en weibsmensch oier setzt muss si sî im bonnert nausdråğe. $(C)$

When setting hens the eggs should be carried in a bonnet.

903. Sạssefrạs is gūt fer hinkelleis. $(C, D, M t, N a, S c, Y)$ Sassafras (sassafras officinale) will drive out chicken lice. 


\section{COOKING AND BAKING}

904. Sauergraut dærf mer net im Fisch ei mache schunscht wærts schleimich. ( $D, L n c, S n, Y$; Heidelberg)

If sauerkraut is made in the sign of Pisces it will become slimy.

905. Brōt as mer uf der Himmelferdåk bakkt wært net grōtzich. $(D, L h)$

Bread baked on Ascension Day will not become mouldy.

Es schimmelt nicht. Hlbg.

906. Wạmmer sạtz mạcht dut mer drei schmǣrte weibsleit nei ${ }^{\sim}$ nō gèt er. $(L n c)$

When starting yeast, put in the names of three capable women.

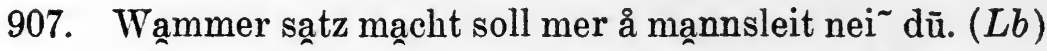
When starting yeast, put into it also the names of some men.

908. Wạmer satz mạcht soll mer drei bēse weiber nei dū. $B e, C, D, L h, L n c, N a, S c, S n, Y$; Lustman)

When starting yeast, put into it the names of three shrews.

909. Wạn der koch sich dōd fresst begråbt mern unich der feierhærd. $(B e)$

If the cook dies from gluttony, he should be buried under the hearth.

910. Wann der koch ferhungert, begråbt mern unich der feierhǣrd. (Lh, Lnc, Sn; Heidelberg)

A starving cook should be buried under the hearth.

911. Der dåk a as mer bakt dærf mer net im gårde schạffe oders sach wært mildåich. ( $\mathrm{Be}, \mathrm{Mr}, \mathrm{Na}, \mathrm{Y})$

Vegetables cultivated on baking day will mildew.

Wer sich beim backen mit laiben beschäftigt, solle an dem tage nicht in den garten gehen, sonst bringe er maulwurfhaufen da hinein. $B M 18$ 
912. En weibsmensch soll ken ærebse oder bōne blanze uf ìr bakkdåk. (Lh, $\mathrm{Na}, \mathrm{Sc}, \mathrm{Y}$; Heidelberg)

A woman should not plant peas or beans on the day that she does her baking.

913. Uf der Kærfreidåk dærf mer net bạke oders gårtesạch wært mildåich. $\quad(B e, C, L b, L n c, S c, S n$; Heidelber)

Baking on Good-Friday will cause garden truck to mildew.

914. Der ladwwærik brennt der net å iちerm koche wannd en kupperner sent odern pærsching schte ${ }^{\sim}$ in der kessel lëkscht. $(B u)$

When boiling applebutter put a copper cent or a peachstone into the kettle to prevent it from scorching.

Man legt einen pfirsichkern hinein. Hlbg.

915. Wammer ken drechterkuche bakt wammer ausgedrosche hot, gebt selli frucht ken gūt mēl un di weibsleit hen ken gūt glik mit îrm bakes. ( $D, L h$;) Nürtingen)

Funnelcakes should be baked after all the grain has been threshed, else the flour made of that grain will not be good and the housewives will have poor luck at baking.

916. Wạnn di brōtgruscht lōsschpringt iberm bake is der bekr drin. ( $\mathrm{Be}, \mathrm{Bu}, \mathrm{C}, \mathrm{D}, \mathrm{Lb}, \mathrm{Mr}, \mathrm{Mtt}, \mathrm{Na}, \mathrm{Sc})$

If the crust separates from the loaf of bread, the baker is in it.

Wenn im brote ein hohler raum ist, sagt man : "da ist eine bäckerseele drinnen." $Z 494$

917. Mer dærf net kēre wạmmer brōt bạkt oders brōt gēt net in di hē. $(L n c, N u)$

If you sweep the kitchen on baking-day, the bread will not rise.

Wer teig im troge hat, kehre die stube nicht aus, bis der teig hinausgetragen st, sonst kehrt er ein brot mit hinaus. $G 3.33$ 
918. Wạmmer kuche bakt un will hạ̄e as si luk wærre muss mer juscht ēne wēk rìre. $(C, D, L b, L h, M r, M t$, $\mathrm{Nu}, \mathrm{Sc}$; Heidelberg)

To make cake light, it must always be stirred the same way. $C S A 1144$

In cooking all the stirring must be done from left to right. G S S cot 30 


\section{VINEGAR}

919. Der essich zạppt mer ẩ der ërscht Freidåkmærğge noch nei licht wanns glōr is. ( $B e, L n c, M t, N a, S n)$ Draw vinegar on the first Friday morning after new moon, provided the weather is clear.

Am Freitag füllt man den essich auf. Lust.

920. Der essich muss mer der ërscht Freidåk im neie licht rumzạppe nō wært er sō glōr ăs wăsser. (Af; Freiburg)

Vinegar should be drawn off and put back into the barrel on the first Friday after new moon and it will be clear as water.

921. Schreib di nåme fun drei bēse weibsleit uf en schtik bânîir un dūs ins essich făss, sell gebt schærfer essich. (Af; Heidelberg)

Write the name of three shrews on a piece of paper and put it into the vinegar barrel if you would have strong vinegar.

922. 'S gebt schærfer essich wạnnd recht bēs bischt wạnnd drå schâffscht. (Lb, Lnc, Na)

If you are angry while making vinegar the vinegar will become better.

923. Wạmmer essich mạcht misse drei weibsleit nei blōse. $(S n)$

Vinegar will be strong if three women blow into the barrel.

924. Wa্রmmer der essich a abzạppt muss mer an drei bëse weibsleit denke nō wært der essich gūt. (Af)

Think of three shrews whenever you work at vinegar, to make it good.

Den besten essig erhält man, wenn man denselben am Freitag ansetzt und drei böse weiber hinein wünscht. Alem 19. 163 
925. Dũ ${ }^{\sim}$ hēs brōt ins essichfáss fer schtæriğer essich. $(B u, M t)$

Hot bread put into the vinegar barrel will make strong vinegar.

926. Ōran zwible ins essichfạss gedũ $\tilde{\sim}$ mạcht schtærğer essich. $(A f)$

To make strong vinegar put common Indian turnips (Arisaema triphyllum) into the barrel.

Orant ist gut für gespenst und zauberei angehängt. $Z f$ D M 4.42

927. En frå mit kind dærf net ạn essich gē. ( $L b, L n c, S c$, $Y$ )

A pregnant woman should not tap vinegar.

928. En weibsmensch dærf net an der essich oder wei gẽ ${ }^{\sim}$ wannn si îr granket hot, oder er schtēt a b. $(A f)$

Wine or vinegar will turn flat if the vinegar barrel or the wine cask is touched by a woman in her periods.

Die unreinheit der frau wirkt auf alles, womit sie in berührung kommt. Sie soll das weinfass nicht berühren, der wein könnte umstehen; das essigfass nicht anfassen, es könnten würmer darin entstehen. $B M 21$

929. Wannd ạm essich schaffscht un bēs bischt oder ferzærnscht des as drå schafft gebts schtæriğer essich. (Be, D, Lb, Lnc, Mr, Mt , a, Nu,Sc, Sn, Y)

If you are or become angry while working at vinegar, or if you can enrage the one who is working at vinegar, the vinegar will become strong.

Wer essig ansetzt, muss sauer dazu schauen und böse sein, sonst misrät der essig. $G 3.81$

930. Schittl 's essichfass im helle dåk. (Be, Nu; Freiburg)

The vinegar barrels should be shaken on a elear day.

931. 'S essichfasss schittlt mer im brillende Lēb. (Sn; Heidelberg)

Shake the vinegar barrels in the sign of the roaring Leo. 
932. Im Lēb schafft mer ăm essich. (Af; Freiburg)

Vinegar should be handled only in the sign of Leo.

933. 'S essichfass schittlt mer uf follicht nō gebts gūter essich. (Be, Lb, Lnc, Sc, Sn, Y; Freiburg)

Shake the vinegar barrel at full moon.

934. Nemm drei drauberanke, nåm si un dū̃ si ins essichfăss, nō gebts gūter essich. (Af; Freiburg)

To make strong vinegar cut three tendrils of a grapevine, name them, and put them into the barrel.

935. Der essich wært drîb wămmern uf en dríber dåk ạb-

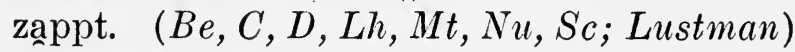

Vinegar will become cloudy if drawn on a cloudy day.

936. En alter sent zū gummere gedū ${ }^{\sim}$ wămmer si sauer macht macht si recht sauer. $(B u)$

Put an old cent into the vinegar used in pickling cucumbers to make them sourer.

937. Wann di leicht aus em haus færtgēt soll ēns di essich fesser schittle, nō wært der essich schtæriğer. (Be, $\mathrm{D}, \mathrm{Lh}, \mathrm{Lnc}, \mathrm{Mr}, \mathrm{Mt}, \mathrm{Na}, \mathrm{Sc}, \mathrm{Sn}$ )

Vinegar will become stronger if the barrels are moved or shaken immediately after the funeral leaves the house.

938. Di essichfesser muss mer rike wann ēns schtærbt schunscht schtēt der essich åb. (Be, D,Lb,Lnc, $M r, S c, Y)$

Vinegar will become stale unless the vinegar barrels are moved when there is a death in the household.

Mit dem eintritt des todes rüttelt man den essig. $M D V$ 269

939. In der Ga्llewoch (der sechzēnt Oktōber) dærf mer ken sauergraut ei mache, es wært bitter. $(A f)$

If sauerkraut is made during the week of Gallus, it will be bitter.

Auf Gallus (16. Oktober) darf man kein kraut einmachen, sonst wird es bitter. $Z f V$ 1896. 183 
940. En nasscht fume wassserpitschbåm in seider oder essich gschtellt macht schtærğer essich. (Be, $D, L b, L n c$, $M r, N u, S n)$

A sycamore twig put into cider or vinegar will make the vinegar strong.

941. Fer schtærğ'er essich dū $\sim$ drei drauberanke nei . (Af; Freiburg)

To make strong vinegar, put into it three cuttings of a grapevine. 


\section{PLANTING, SOWING AND REAPING}

942. Grumbìre blannzt mer im zūnemmede im Lēb. (Af; Heidelberg)

Plant potatoes in the increase of the moon in Leo.

943. Di būne bląnzt mer im î́berschtēede. (Af; Heidelberg)

Plant beans when the horns of the moon point upward.

944. Der rłbsūme sēt mer uf der Pēterkétt (der ērscht Åguscht) oder Lårenzius (der zēet Åguscht. (Be, $L h, S c, S n)$

Sow turnips on Peter Ketten or Laurentius.

Säet man die rüben zu spät nach Lorenzen, so wachsen die rüben nur noch in den schwänzen. $Z f V$ 1894. 127

945. Wạmmer net geblōkt sei ${ }^{\sim}$ will mit ǣrdflē, sēt mer der sūme ōteds wann di sunn unner is oder mærğets eb si uf is. (Be, C, Lh, Na, Sc, Sn)

If seed is sown after sunset or before sunrise fleabeetles will not infect the plants.

Gegen erdflöhe : man bringt den dünger vor sonnenaufgang aus dem stall auf den haufen, so bekommt das damit gedüngte feld keine flöhe. $W u 416$

946. Ebbel as in der Gallewoch geroppt wærn wærn bitter. (Be, C, D, Lb, Lh, Lnc, Mr, Mt, Na, Sc, Sn, Y; Heidelberg)

If apples are picked in the week of Gallus (Oct. 16) they will be bitter.

947. In der Gallewoch (sechzēt Oktōber) roppt mer di ebbel. $(B u)$

Apples should be picked in the week of the sirteenth of October. 
948. In der Gēlwovh (im Moi) dærf mer ken welschkærn bląnze, schunscht wærts gēl. (C, D, Lh, Lnc, Sc,Sn, $Y$; Ettlingen)

Corn must not be planted in yellow [?] week, else it will become yellow.

949. Im Grischmūnet blūkt mer net, seller mūnet muss mer der grund rūğe losse. $(B e, C, L b, L h, L n c, M r$, $M t, N u, S c, S n$; Heidelberg)

No ploughing should be done in December, the soil should have a rest that month.

950. Wạnn di quạtemberdåk hōch im mūnet sin wært di frucht deier. $(A f)$

Grain will be high in price if the Emberdays come late in the month.

Hat der Quatember eine hohe datumzahl, so wird das getreide teuer. $Z f V 1891.190$

951. Uf der Assche Mittwoch soll mer esch in der gårte schtrēe, no grikts gårtesach ken leis. ( $A f ; \mathrm{Hei}$ delberg)

Spread ashes over the garden on Ash Wednesday to prevent lice on garden vegetables.

952. Wạnns difer schnē hot uf di Fåsenạcht gebts lạngen flax sell jōr. $(B u, M t)$

The length of flax is indicated by the depth of snow on Shrove Tuesday.

953. Ken reğe uf der ērscht Moi

Gebts å ken hoi. (D, Y; Heidelberg)

No rain on the first of May

And there'll be no hay.

954. Wạmmer reddich schtekt muss mer såğe: so lạng ås mei ${ }^{\sim}$ åm, so dik âs mei $\sim$ be $\bar{e}^{\sim}$. $(B u, M t)$

When sowing radish seed say : as long as my arm, as thick as my leg.

Stecken die weiber kraut, so sagen sie: "Dursche wie mein dickes bein, haide wie mein kopf, blätter wie meine schürze, so werde mein kraut." $G 3.518$ 
955. I万erm reddich sēe muss mer såğe: so lang ås mei årm, so dik a as mei ${ }^{\sim}$ åsch. $(B e, L b)$

When sowing radish seed say: as long as my arm and as big as my buttocks.

956. Wạmmern fląx der årsch weisst wært er hōch. (Bu,C, $L b, L h, M r, N u, S c, S n)$

Flax will grow tall if you show it your buttocks.

Wie schiesst der flachs erst in Ostpreussen empor, wenn die frauen ihm am Johannisabend plötzlich ihren blossen hintern zeigen! $M D V 227$

957. Wạnn di weibsleit mit em årsch blōs leie is es zeit fer welschkærn blanze. $(S n)$

It is time to plant corn when women throw off the blankets in bed at night.

958. Wann di lōges ærik blìe gebts en gūt welschkærnjōr. $(B e, B u, C, D, L n c, M r, M t, N a, N u, S n, Y$ )

If locust trees bloom profusely, the corn crop will be good. ......Dann gibts überhaupt einen guten sommer. Hlbg.

959. In der mukewoch [oder mikewoch] sēt mer ken wēze. $L b, N u, Y$ )

No wheat should be sowed during Fly Week [?] [Mikleta, Sept. 18?].

Am tage Mauritii [22. Sept.] soll man keinen waitzen säen, er wird sonst russig. $G R 567$

960. In der Greizwoch sēt mer ken wēze. ( $D, L b, L n c, S n$; Freiburg)

No wheat should be sowed during the week of the Elevation of the Holy Cross [September 14].

961. Di būne blanzt mer in der Jungfrau. (Be, $B u, L b$, Lnc, $M t, N a, S c, Y$ )

Plant beans in the sign of Virgo.

Gut für bohnen ist das zeichen der Jungfrau. $R A 300$

962. Der Kærfreidåk soll mer grautsūme sēe. $(M r)$

Sow cabbage seed on Good Friday.

It is lucky to sow all kinds of garden seeds on Good Friday. H 50 
963. Uf der Kærfreidåk soll mer blumesūme sēe un blume bląnze, nō blie si gūt. $\quad(C, L b, L n c, S c)$

Sow flower seed and plant flowering plants on Good Friday, so that the plants may bear many flowers.

Karfreitag gilt als glücklicher säetag. $Z$ f $D M 2.102$

It is lucky to sow all kinds of garden seeds on Good Friday. H. 50

964. Grumbîre as mer nommidåks blanzt gebe net gut aus. $(B e, D, L b, L h, S c, S n, Y)$

Potatoes will not yield well if planted in the afternoon.

Kartoffeln müssen vormittags gelegt werden. W $W 424$

965. Grumbìre blanzt mer der hunnertscht dåk. ( $D, L n c$, $\mathrm{Na}, \mathrm{Nu}, \mathrm{Sn}, \mathrm{Y}_{\mathrm{Q}}$

Plant potatoes on the hundredth day of the year.

Kartoffeln pflanzt man am besten am 100. tage des jahres. $W u, 424$

966. En frå dærf ken pēterli ausblaanze schunscht schtærbt îr mąnn. (Be, " $C, D, L b, L h, M r, N u, S c, Y)$

A woman will lose her husband if she transplants parsley. Ausgegrabene petersilienwurzeln darf man nicht wieder pflanzen, sonst pflanzt man den gatten in die erde. $W u 425$

967. Wạmmer pēterli ausblạnzt hot mer ken glik. ( $\mathrm{Na})$

You will have no luck if you transplant parsley.

It is unlucky to transplant parsley. $H 57$

968. Wạmmern pēterli schtok blanzt schtærbt em sei beschter freint. $(L b)$

Your best friend will die if you plant parsley.

Ausgegrabene petersilienwurzeln darf man nicht wieder pflanzen, sonst pflarzt man seinen besten freund in die erde. $W u 425$

969. Mer muss ken pēterli ins haus bỉanze oders schtærbt ēns aus em haus. $(A f)$

A member of the family will die if you transplant parsley in to pots. 
Ausgegrabene petersilienwurzeln darf man nicht wieder pflanzen, sonst pflanzt man seinen besten freund oder den gatten in die erde, bringt ihm den tod. Wu 425

It is unlucky to transplant parsley. $\quad V S L 2.168$

970. Mærze schtåb is gold wæ̈rt. (Bu, Mt, Sc)

Dust in March is worth its weight in gold.

A peck 0' March dust is worth its waicht in goud. G Scot 150

971. En handfoll Mærze schtåb is so fill wæ̈rt as en buschel frucht. (Lh, Lnc, Mr, Na, Sn; Heidelberg)

A handful of dust in March is worth a bushel of grain.

972. Zwische Kærfreidåk un Ōschtre dǣrf mer net im gårte schăffe, selli zeit hot Jēsus in der ǣrd geleğe. (Be, $L h, S n$ )

No gardening should be done between Good Friday and Easter, for during that time Jesus lay buried.

Karfreitag und Samstag darauf getraut man sich nicht in der erde zu arbeiten, um Christus nicht im grab zu beunruhigen. G 3. 706; $H N C 81$

973. Im unnerschtēende mūnd soll nix gebląnzt wærre ąs an de schteke nuf soll, wî̀ zum beischpill būne un ærbse. (Af; Heidelberg)

Climbing plants, e. g., beans and peas should not be planted in the decrease of the moon (or when the horns of the moon are turned downward.

Plant peas and potatoes in the increase of the moon. $C$ $S$ A 1120

974. Wạmmer gum'mere im Zwilling blanzt gebts fỉl. ( $N a$; Heidelberg)

If cucumbers are planted in the sign of Gemini they will bear well.

975. Wạmmer wisse will welli sōd'frucht di bescht is nemmt mer drei ēre fun der ērschte lōd, drei fun der mittelschte un drei fun der letschte. Mer macht si aus, un blanzt si, un dî̀ wūs bescht ufgēt nemmt mer nō fer di sōd. (Lh) 
To ascertain which grain to take for seeding, take three ears from the first load of grain hauled into the barn, three from the middle load, and three from the last. Sow the grains contained in these ears and that which sprouts first indicates which is the best seed grain.

Neun tage vor Weihnachten wird getreide in einem von erde gefüllten napf gesät, und aus dem keimen und der höhe desselben am Christtage der Erntesegen des kommenden jahres prophezeit. $W 83$

976. Di būne blanzt mer uf der Bonifă'zius (der finft Jūni), nō gebts fîl. $(B e, C, L b, L h, M r, N a)$

For a large crop of beans, plant them on Bonifacius.

Die bohnen soll man am Bonifaziustage mittags zwischen

11 und 12 eigentlich wenn die glocke $12 \mathrm{uhr}$ schlägt, stecken, dann hängen sich die stöcke voll. Alem 19. 164

977. Schmîr di schipp wū mer gær'delt mit mit fåsenąchtfett, sō âs es ken wærm in der gårde gebt. $(C)$

Before digging the garden grease the spade with Shrove Tuesday cakefat so as to keep worms away.

Man schmiert die schippe nit öl. Hlbg.

978. Eb mer å fạngt frucht hēmfåre reibt mer di frucht'găble mit fåsenachtfett, no kumme di wi'ble net in di scheier. $(N a, S c, S n)$

Before beginning to haul grain from the fields, grease the grain forks with lard in which doughnuts have been baked, to prevent weevils from getting into the grain.

979. Eb mer å fangt frucht hēmfåre schmîrt mer der lē'derwăğe mit fåsenachtfett, nō kumme di ratte net in di frucht. $(B e, D, L h, L n c, S c, Y)$

Before beginning to house grain grease the wheels of the wagon with lard in which doughnuts have been baked.

Fassnachtsschmalz ist wunderschmalz. Es wird auch verwendet zum einreiben der pflugschar. $B M 24$

980. Mer solls bluk'schår mit fåsenachtfett schmíre eb mer å fangt blūğe, nō fresse di wærm's welschkærn net ąb. $(B e, L h, N a)$ 
Cutworms will not destroy the young corn if the ploughshare is greased with doughnut fat before beginning to plough.

In Steiermark beschmiert der hausälteste alles eisen am ersten ins feld fahrenden pflug mit dem speck der am Oster Sonntag geweiht war. M D V 219; B M 24

981. Welschkærn bląnzt mer im Grebs oder Lēb. (Af)

Plant corn in Cancer or Leo.

Man pflanzt es im Löwen. Hlbg.

982. Wămmer ken ǣrn'kichelcher băkt wạmmer mit der ǣrn færtich is gerōt' di sōt net. (Lh; Nürtingen) The coming year's crops will be a failure unless you bake doughnuts at the end of harvest.

983. Wạmmer der glēsūme net im unnerschtēende sēt schtellt sich der glē obe ufs land. (Af)

If cloverseed is not sown in the decrease of the moon, the clover will sit on the ground.

984. Der glēsūme sēt mer im unnerschtēende Grebs, nō gfrìrt er net raus. (Af; Heidelberg)

Clover will not freeze out in winter if the seed is sown in the decrease of the moon in Cancer.

985. Rōt'ríbe blạnzt mer im Lēb, nō bleibe si rōt. $(B e, D$, Lh, Lnc, $\mathrm{Na}$; Heidelberg)

Beets will remain red if planted in Leo.

986. Wămmer lange gummere hăbe will muss en mannnkærl si blănze. $\quad(B e, C, L h, L n c, M r, N a, S c, S n, Y$; Heidelberg)

If large cucumbers are wanted, a man should plant them.

987. Di grumbìre blạnzt mer in de dunkle nachtē. ( $A f$; Heidelberg)

Plant potatoes in the dark of the moon.

988. Di grum'bīre bląnzt mer im Wăssermannn. ( $D, N u$, Sn)

Plant potatoes in Aquarius.

Nicht im Wassermann. Hlbg. 
989. Di grumbî̀re bląnzt mer im Widder nō gebts wider. (Sn, $Y$; Heidelberg)

For a good crop plant potatoes in Aries.

990. 'S gebt schēne grautblanze fum sūme as mer uf der Gertrūdsdåk (der sī̄ezēt Mærz) oder der Detlausdåk (der ēnundreissichscht Mærz) sēt. (Be,C,Lb, $L h, L n c, M r, M t, N a, S c, S n, Y$ )

For fine cabbage plants, sow the seed on Gertrude's day (Mar. 17) or Detlau's day (March 31).

17. März. St Gertraud war die erste gärtnerin, darum soll man an diesem tage "garteln". Z 1236

991. Zwible as uf der ēnunzwan'zichscht Mærz geblanzt sin geøe gūt aus. (Be, Bu, Lh, Lnc, Mr, Mt, Sc, Sn)

If you plant onions on March 21 you may expect a good crop.

Dann schiessen sie alle. Heidelberg.

992. Welschkærn im Schitz geblanzt grikt fil låb ąちer wenich kolbe. (Be, Bu, Lh, Lnc, Mr, Mt, Sc, Sn, $Y$; Heidelberg)

Corn planted in Sagittarius will be rich in foliage but poor in ears.

993. Wămmer di sōt Mūndåks oder Mittwochs å fạngt schtærbt ēns aus der fami'lie. ( $L h, Y)$

If fall sowing is begun on Monday or Wednesday, some one in the family will die.

Mittwochs soll man nicht säen. Heidelberg.

994. Der glēsūme sēt mer im Grebs, nō grikt er gūte wærzle. (Af; Heidelberg)

Clover will have bushy roots if the seed is sown in the sign of Cancer.

995. Zelåt'sūme sēt mer im Grebs, nō grikt er gūte wærzle. $(C, D, L h, L n c, M r, N u, S n)$

If lettuce is sown in Cancer the lettuce will have good roots.

996. Grumbíre blanzt mer in de dunkle nạchte, dåks fær nei licht, nō gebts fìl un schēne. (C, $L h, M r, N a, N u$, $S c, S n, Y$; Heidelberg) 
The potatoe crop will be large and the potatoes of good size if the potatoes are planted in the dark of the moon, i. e. the day before new moon.

997. Grumbìre im Schtē'bok geblannzt gebe nix wi glēne. (Be, C, Lh, Lnc, $\mathrm{Mr}, \mathrm{Nu}, \mathrm{Y}$; Heidelberg)

Potatoes planted in Capricornus will be small.

998. Freidåks fạngt mer å sēe un Freidåks gebt mer uf, nō hot mern gūti ǣrn. Wạmmer fær sellem færtich wært, muss mer der sak uf di fens henke un dært henke losse bis wider Freidåk un nō færtich mache. (Be, Lh, Lnc, Mt, Sc, Y)

Bègin sowing on Friday and end on Friday, and you will have a good harvest. If you can finish before Friday, hang the grainbag on the fence until the following Friday when the sowing should be completed.

An einem Freitag muss man zum erstenmal einspannen und die ernte beginnen. $W u 61$

999. Di sōt muss mer der sēm dåk ufgebe âs mer druf å gfănge hot. (Sn)

Begin and finish sowing on the same weekday.

1000. Der buch'wēze sēt mer uf der si'teschlēfer. (Be, $C$, $L b, L h, M r, N u, S c, S n, Y$; Freiburg)

Sow buckwheat on Seven Sleepers (June 27).

1001. In de Hunnsdåk dærf mer net âm graut hake, 's wært lausich. $\quad(C, L b, L h, M r, N a, S c, S n, Y)$

Cabbage plants cultivated during dogdays will be infected with plantlice.

Sie werden flohig. Heidelberg.

1002. Wămmer blumeschtek zĭğe will muss mer sich di neschtelcher schtēle wū mer si defun' zíğe will. ( $A f$; Heidelberg)

To be successful in raising flowering plants, steal the slips.

1003. Wạmmer blume blạnzt soll mer sich gråd hî hoke, nō gēn si net in di hē. $(C, L h, S c, Y$; Lustnau $)$

If you sit down immediately after planting flowers they will be short and stocky. 
1004. Blume blanzt mer im Grebs, nō wærre si ni'der un brēt. (Be, Lnc, $M r, N a, S c$; Freiburg)

Flowering plants set in Cancer will grow low and stocky.

1005. Im Fisch soll mer ken gummere bląnze. (Be, $L b$, $\mathrm{Na}$ )

Never plant cucumbers in Pisces.

1006. Grumbìre as mer im Grebs blannzt wærre zwą'kich. (Af; Heidelberg)

Potatoes planted in Cancer will not grow round and smooth.

1007. Di grutze fum bląnz'welschkærn dærf mer net ferbrenne oders welschkærn grikt der brannt. (Af; Heidelberg)

If the cobs, from which seed corn has been taken, are burned, there will be much cornsmut.

1008. Wămmern gwendelschtok bląnzt soll mer sich druf hoke oder er waxt net. $(B e, L h, M r, M t, S c)$

Unless you sit on thyme (thymus vulgaris) after planting it, it will not grow.

1009. Wămmer blănze, oder sō ebbes grikt dærf mer sich net bedănke oder si waxxe net. ( $A f)$

Never thank anyone for plants for the garden; they will not grow if you do.

Für geliehenen samen darf man nicht danken, sonst gedeiht er nicht. $W u 405$

1010. Wămmer pè'terli blanzt waxt er net mitaus' mer brunst ērscht ins loch. (Bu, Lh, Sc)

Urinate into the hole where you expect to plant parsley or it won't grow.

Beim krautsetzen setzen sich die frauen gegenseitig nieder. $M D V 228$

1011. Wăs im Schitz geblanzt is schísst. (Af)

Everything planted in Sagittarius will run to seed.

Im schützen wird alles hoch. Pflanzen, die nicht hoch gehen sollen, darf man also nicht im schützen säen. B S 33. 128 
1012. Aalles ạs mer im Lēb blannzt wạxt ærik. (Af; Heidelberg)

Everything planted in Leo will grow well.

1013. Im Zwilling blanzt mer di būne oder gummere. (Af; Heidelberg)

Plant beans and cucumbers in Gemini.

1014. Mer soll nix in der Wạssermannn sēe, oders wært wassserich. (Af)

Everything planted in Aquarius will be watery.

Früchte, welche man weich liebt, müssen im Wassermann oder den Fischen gesät werden, weil dann die pflanzen oder früchte saftig werden. $B S 33.128$

1015. Der Siøeschlēfer lēkt mer di zwiநle um, nō wærre si diker. ( $B e, B u, C, L b, L h, L n c, N a, S c)$

Bend over the tops of onions on Seven Sleepers (June 27) to make them grow large.

Dann schiessen sie nicht. Hlbg.

1016. Pēter un Paul

Mạcht em kærn di wærzel faul. $(A f)$

On Peter and Paul's day (June 29) rye begins to die.

Peter and Paul.

Machen dem korn die wurzel faul. Alem 25. 243

1017. Im Fisch blanzt mer gummere un reddich, nō wærre si lang. (Af)

Cucumbers and radishes planted in Pisces will grow to good length.

1018. Grumbìre blanzt mer in de dunkle nachte un uf di wōk. $\quad(C, D, L b, L h, L n c, M r, M t, N a, S c, Y$; Heidelberg)

Plant potatoes in the last quarter and in Libra.

1019. Di grumbire blanzt mer in der wōk o'derm Lēb, nō wĭge si schwēr. (Af; Heidelberg)

Potatoes planted in Libra or Leo will weigh very heavy. 
1020. Būne oder gummere in der Jungfrau geblangt dūn nix wí blie, si henke net $\mathrm{a}^{\sim}$. $(A f)$

Beans or potatoes planted in Virgo blossom profusely but do not bear.

Man soll keine grundbirnen in dem zeichen der Jungfrau pflanzen, sonst verblühen sie alle. Alem 19. 166

1021. Di gummere blanzzt mer net im Grebs, si dūn nix w1 ranke. $(B e, B u, C, D, L h, M t, N a, N u, S c, Y)$

If you plant cucumbers in the sign of Cancer they will shoot téndrils all season and not bear.

Gurken steckt man im zeichen des Skorpions. $W u 426$

1022. In der Jungfrau blanzt mer di blume rum. ( $A f$; Heidelberg)

Transplant flowering plants in Virgo.

1023. Di blumeschtek blanzt mer im zu'nemmede in der Jungfrau. (Af; Heidelberg)

Plant flowering plants in Virgo in the increase of the moon.

1024. Gårdezelåt' schìsst net wammern im unnerschtēende blanzt. (Be, Bu,Lb,Lh,Lnc, Mr, Mt,Sc,Sn, Y; Heidelberg)

Plant lettuce in the decrease of the moon to prevent it from running to seed.

1025. Schtekebūne gēn net an de schteke nuf wạmmer si im unnerschtēende blanzt. (Af)

Pole beans will not climb if planted when the horns of the moon turn down.

Gewächse, die ihre frucht über der erde tragen, müssen bei zunehmenden mond gesäet werden. $W u 58$

1026. Di gum'mere blannzt mer im Fisch nō wærre si glạtt. (Af)

If you plant cucumbers in the sign of Pisces, the cucumbers will be smooth.

1027. Blumeschtek ass mer uf der Kærfreidåk blanzt grtğe schekiche blume. $(\mathrm{Na})$ 
Flowering plants planted on Good Friday will bear variegated flowers.

Blumen am Gründonnerstag gesäet erhalten schöne farben. $W u 73$

1028. Wămmer ebbes blanat in Gottes nåme waxxts. $(N u)$ Anything planted in the name of God will grow.

"In Gottes namen sa i mein lein", sagt die säerin. A J 196

1029. Welschkærn dærf mer kens bląnze uf en dåtem wī en null hinne drå is. (D, Y; Freiburg)

Corn must not be planted on a date ending in a cipher.

1030. En blumeschtok as mær fume gråb schtēlt waxat net. $(B e, L b, M t, S n)$

A flowering plant stolen from a grave will not grow.

Reisst man blumen von gräbern ab, so kommt sie der tote als sein eigentum wieder holen. $D r 304$

1031. Der hạ̄er ei ${ }^{\sim}$ schmîre, der buch’wēze ei schtåťe. (Be, $\mathrm{Bu}, \mathrm{Lnc}, \mathrm{Mt}, \mathrm{Na}, \mathrm{Sc}, \mathrm{Y}$ )

Sow oats in wet, buckwheat in dry ground.

Der hafer gedeiht, wenn der zur aussaat gehende bauer mit wasser bespritzt wird. $W u 420$.

1032. Wămmer pē'terli sūme sēt un er waxt gebts en kind in di fami'lie; wạnn net, schtærbt ēns aus der fạmi'lie. $(D)$

If one sows parsley seed and it sprouts, it means an addition to the family; if not, a death.

Es stirbt jemand im hause, wenn gesäte petersilie nicht aufgeht. $W u 213$

1033. Wặmmer di frucht hēmfårt soll mer bal'sem ąbschneide un uf der båre lēge eb mer di frucht druf dut, nō kumme di rânte net in di frucht. ( $\mathrm{Be}, \mathrm{Na}$, $S c, S n ;$ Heidelberg)

To keep rats out of the grain, cut spearmint (mentha viridis) and put it in the mow before putting any grain there.

1034. Glēsūme sēt mer der ērscht Anbril'. (D, Lnc, $Y$; Lustnau)

Clover seed should be sowed on April 1. 
1035. In der Blu'mefrå dærf mer ken grum'błre blạnze. $(D ;$ Heidelberg)

Do not plant potatoes in Virgo.

1036. Es gebt di lengschte gummere wammer si der lengscht dåk blanzzt. (Lnc; Heidelberg)

To raise the largest cucumbers, plant them on the longest day.

1037. Blannz ken rōt'ríbe im Schtē- bok, si wærre hært. (Be, $\mathrm{Nu}, \mathrm{Sc}$ )

Beets planted in Capricornus become hard.

Kartoffeln dürfen nicht im Steinbock gepflanzt werden, sonst werden sie hart. $W u 424$

1038. Mærze schnē is sō gūt wì en kōt mischt. (Be,Lnc)

March snows are as efficacious as a coat of manure.

April schnee düngt, März schnee frisst. Z 1305

1039. Schnē unnerblūğe is juscht sō gūt fern feld âs mischt un ka ${ }^{\prime}$ lik. $(A f)$

Turning down snow with a plow is as good for a field as manure and lime.

April schnee düngt..... Z 1305

1040. Graut un dūbankblannze blannzt mer der hunnert dåk. $(L n c)$

Plant cabbage and tobacco on the hundredth day.

1041. Wạmmer di grumbìre uf der Sēnt Pątricksdåk blạnzt gebts grōsse un si geђe gūt aus. (C, Lnc, Mt, Nu, $S n, Y$ )

If you plant potatoes on St. Patrick's day potatoes will be large and the crop big. 


\section{TREES}

1042. Bēm dråğe net wạmmerne net Neijōr å̃ schìsst. (Be, $B u, C, L h, M r, M t, N a, S c, S n)$

Fruit trees will not bear unless they are wassailed on New Year's Eve.

On Twelftheven, in Devonshire, it is customary for the farmer to leave his warm fireside, accompanied by a band of rustics, with guns, blunderbusses, etc., presenting an appearance which at other times would be somewhat alarming. Thus armed, the band proceeds to an adjoining orchard, where is selected one of the most fruitful and aged of the appletrees, grouping round which they stand and offer up their invocations in the following quaint doggerel rhyme:

"Here's to thee,

Old apple tree!

Whence thou mayest bud,

And when thou mayest blow,

And whence thou mayest bear

Apples enow :

Hats full,

Caps full,

Bushels, bushels, sacks full,

And my pockets full too!

Huzza! huzza!"'

The cider jug then passed round, and, with many a hearty shout, the party fire off their guns, charged with powder only, amidst the branches....... D A 278-280

1043. De ōbschtbēm winscht mer Neijōr, nō dråğe si besser. $(A f)$

Trees will bear better, if you wish them a Happy New Year.

Man wünscht dem obstbaum ein neues jahr in der Wetterau wie in Hannover und Brandenburg. Auf diese weise macht man ihn fruchtbar. $M D V 206$ 
It is the custom in the cider district of Sussex to worsle (wassail) the apple trees on New Year's Eve. $F R 1.13$

1044. Wạnn en båm net dråğe will muss mer nei ${ }^{\sim}$ schîsse. $(B e)$

Shoot into a tree that will not bear fruit.

Obstbäume werden fruchtbar gemacht, wenn man unter sie schiesst. $W u 426$

The custom of firing under appletrees is not entirely defunct in Devonshire. $D E C 49$

1045. Wămmern schtrō'sēl um di eb'belbēm binnt dråğ'e si besser. (Af)

Appletrees will bear better if you wisp the trunks with straw.

1046. Di Neijōr wikelt mer en schtrō'sēl um di ōbschtbēm. $(B e)$

Wrap a wisp of straw round fruit trees on New Year's.

In der Neujahrsnacht umwickeln die bauern mit einem strohseil ihre obstbäume. MDV 206

1047. Wạn en uf'gebindelt weibsmensch en båm schittelt dråkt er. $(C, M r)$

If a pregnant woman shakes a fruit tree, it will bear.

1048. Bēm hẹke æ'rik å wămmer si uf der Esche'pudel mit esch schtrēt. (Af; Heidelberg)

Trees will bear very well if they are strewn with ashes on Ash Wednesday.

1049. Jēderm ōbschbåm a as net dråkt, schneit mer der Eschemitt'woch en wip a ab. $(D, S n)$

Cut a twig on Ash Wednesday, from every fruit tree which does not bear fruit, to make it fruitful.

Das tut man an den birnbäumen. Hlbg.

1050. Der Kærfreidåk schittelt mer di bēm a a net dråğe wolle. $(C, M r, S c, S n, Y)$

Trees that will not bear should be shaken on Good Friday. Obstbäume werden fruchbar gemacht, wenn man sie früh am Karfreitag stark schüttelt. $W u 426$ 
1051. Mer schląkt neğel in en båm ås net dråğe will. (Mr, $M t, S c, \hat{Y}$ )

Drive nails into trunks of trees that will not bear.

Am Karfreitag macht man kleine hämmerlein aus holz und schlägt die bäume damit, dann gerät das obst gut. V A S 1. 472

1052. Bēm wū net dråğe wolle muss mer der Kærfreidåk wipe. (Lnc, $S n, Y$ )

Trees that will not bear should be whipped on Good Friday. Bäume werden fruchtbar gemacht, wenn man sie in der Weihnachtszeit prügelt oder am Karfreitag stark schüttelt. $W u 426$

Whipping a walnut tree tends to increase the product and improve the flavor of the fruit. $D E$ Eng 25

1053. Wạn bëm net dråğe wolle henkt mer eise drå? (Be, Lb, Lh, Lnc, Mt, Sc, Sn, Y; Heidelberg)

Hang pieces of iron on fruit trees that will not bear.

1054. Wạnn en båm net dråğe will bōrt mern loch in der schtąmm un schląkt en zạppe nei fume båm a as drecht. $(C, S c)$

If a tree will not bear bore a hole into its trunk and plug up the hole with wood from a tree that bears well.

1055. Bēm wū wider ausschlăğe solle misse im zu'nemmede ab'kaknt wærre. $(A f)$

If trees are to sprout again they should be felled in the increase of the moon.

Bäume, welche wieder aus der wurzel ausschlagen sollen, müssen im zunehmenden mond gefällt werden. $B S$ 33. 128

It is lucky to fell trees at the wane of the moon. $H 51$

1056. En schōf ăs glei ferrekt wanns uf di welt kummt henkt mer uf en a abbelbåm, nō dråkt der ạbbelbåm. (Be, C, D, Lh, Lnc, Mt, Na, Nu, Sc,Sn, Y)

An appletree will bear fruit if a dead lamb is hung on its branches. 
A lamb that is dropped dead or that dies while still very young is customarily hung up in a tree-properly in a thorn, though any fruit- or berry-bearing tree will do. C F Y 2.68

1057. Wạmmer bēm im folllicht blannzt, dråğe si aerik. (Be, $D$, Lnc, Sc; Heidelberg)

Trees planted at full moon will bear very well.

1058. Uf der ebbel dåk (der finfunzwăn'sichscht Mærz) eb sunn'ufgąng: schittelt mer di ebbelbēm, nō dråğe si immer gūt. ( $S n$; Heidelberg)

Appletrees will always bear well if shaken on March 25 before sunrise.

1059. Wămmern båm bląnzt drēt mern fescht mit der sunn. (Be, C,Lnc, Na, Nu, Sc, Y; Heidelberg)

When planting a tree tramp the ground in the direction of the sun, i. e. from east to west.

1060. En båm im a ab'nemmede geblanzt gebt ken ōbscht. (Be, C, Lnc, Mr, Nu, Sc; Heidelberg)

Trees planted in the decrease of the moon will not bear.

1061. Mer blanzt nî̀ en båm hĩ wū ēner gschtannne hot. (Be, Lh; Kaiserslautern)

Never plant a tree on the spot where a tree had stood.

1062. Wạnnd en båm rum'blanzzscht, dū $\sim$ di sēm seid gēğich di sunn ăs drin wår. (Af; Göppingen)

When transplanting a tree be careful to have the same side facing the south.

1063. En båm dråkt noch'emōl sō fìl wạnn en frå mit kind en helft blanzze un hēbt en mit de zwē hend i'berm blanze. (Be, Lb; Heidelberg)

If a pregnant woman helps to plant a tree by holding it with both hands the tree will bear doubly well.

1064. Wạnn en båm net dråğe will wi'kelt mern lumbe der ō̋ed fær Grischdåk noch sunn'unnergąng un mer såkt: 
In dǣre nacht is Grischtus gebōre.

$\mathrm{Du}$ bischt noch ni ferfrōre.

Ich wi'kel dich mit lumbe.

Nau henkscht du dich mit glumpe. $(B e, L h)$

If a tree does not bear fruit, tie rags around its trunk on

Christmas eve before sunset, saying:

Christ was born on Christmas eve.

You shall not freeze but live.

With these rags I wrap you round

That in much fruit you may abound.

Aehnliches. Freiburg.

1065. Wămmern båm nufgukt wạnn en weibsmensch druf is wært mer blind. $(B u, D, L b, L h, M r, M t, N a, Y)$ You will become blind if you look up into a tree while a woman is on the tree.

Wer auf einen baum sieht, auf dem eine weibsperson sitzt, wird blind. $G$ 3. 621

1066. Wanns gschwi'schich Grischdåk un Neijōr windich is, schpìle di ebbelbēm, nō gebts fìl ōbscht. ( $B e, D$, $L b, L h, L n c, M r, N a, S c, Y$ )

If there are high winds between Christmas and New Year, the trees copulate and there will be much fruit.

Ist es zum Neujahr windig, so gibt es viel obst. $W u 197$

1067. Wạnn en båm fălsch blìt un en weibsmensch in fạmi'lie umschtende schittelt en, gebt er frucht. ( $B e$, $L b, L h, L n c, M r, S n, Y$; Heidelberg)

A tree which blossoms but does not bear will begin to bear if it is shaken by a pregnant woman.

1068. Wạnn bēm net dråğe wolle muss en frå mit kind si frìjōrs schittle wạnn si blîe. $(B e, C, D, L b, L h$, Lnc, $M r, N a, N u, S n, Y$; Heidelberg)

If trees will not bear they should be shaken, while in blossom, by a pregnant woman.

1069. 'S holz fume båm wūs gewitter nei gschlăğe hot dærf mer net unner me dach ferbrenne weğe feier im haus. ( $B e, D, L b, L h, L n c, M t, N a, S n, Y)$ 
Wood from a tree struck by lightning must never be burned in a house for fear of fire.

Holz von bäumen, in welche der blitz geschlagen, darf man nicht im haus verbrennen, weil sonst das feuer aus dem ofen herausläuft, und man kann es nur durch geweihte wasser löschen. $W u 97$

1070. 'S holz fume båm wūs gewitter nei gschlạğe hot dærf mer net nemme fern haus oder scheier baue, schunscht schlechts gewitter å dært nei . (C, Mr, $M t$ )

Wood from a tree struck by lightning must never be used in the construction of a house or barn, or the latter will also be struck by lightning.

Das holz eines vom blitz getroffenen baumes darf nicht zum bauen verwandt werden, sonst schlägt der blitz ein. $W u 14$

1071. Mer dærf ken holz wūs giwitter nei gschlăğe hot kat ime haus ferbrenne, schunscht schlakts gewitter å ins haus. $(B e, C, L n c, M r)$

If wood from a tree which was struck by lightning is burned in a stove, lightning will strike the house.

1072. Ōbschtbēm un drauђe'ranke schneit mer im foll licht. (Af)

Fruit trees and grapevines should be pruned at full moon.

1073. Bauholz muss mer im Disem’ber hake. (Sc; Heidelberg)

Trees for building purposes should be felled in December.

1074. Poschtē wēre lenger wămmer si 's un'nerscht 's e'ђerscht ei gråbt. ( $D$; Heidelberg)

Fence posts will wear much longer if they are set upside down.

1075. Wammer bauholz hakt wạnn di saft drin is wærts holz wærmich. (Be, C, Mr; Heidelberg)

If trees are felled while the sap is rising the timber will become wormeaten. 
1076. Holz âs uf di Neijōr kakt wært wērt fłl lenger fer poschte un sō dings. ( $L h, N u, S c, S n$; Heidelberg) Posts, etc., will last much longer if the trees are cut down on New Year's.

1077. Holz hakt mer im Lēb, sell machts schtæ'rik. (Lh; Heidelberg)

Fell trees in the sign of Leo and the timber will be strong.

1078. Di nacht'gschærre soll mer ăn pærsching bēm auslēre, nō dråğe si besser, oder mer soll weder si brunse. (Af; Heidelberg)

Empty the pot at the peachtree or urinate against it, so that it will bear better.

1079. De bēm un blu'meschtek muss mer Neijōr winsche schunscht gebts nix raus. ( $B e, L b, L h, L n c, M r, N a$, $S c, S n)$

Trees and flowering plants will not thrive unless you wish them a Happy New Year.

Die bauern wünschen dem obstbaum ein neues jahr in der Wetterau, Hannover und Brandenburg. $M D V 206$

1080. Bēm às dråğe solle muss mer im zunemmede rumbląnze, trime, zweiğe oder blēdle. (Af)

If trees are transplanted, trimmed, grafted or budded in the increase of the moon they will bear much fruit.

Das umpflanzen junger bäume, das schneiden derselben, kopulieren, okulieren, pfropfen usw. muss im zunehmenden mond geschehen. $B S 33.128$

1081. Wannn en båm net dråğe will, schląkt mer neğel nөi . $(C, D, L b, M r, N a, N u, S c, S n, Y)$

If a tree will not bear fruit, drive nails into it.

1082. Wạnn en båm net dråğe will låd mern mit eise un schtē $\tau$. (Af)

If a tree will not bear fruit load it with iron and stones.

Packt man im Brandenburgischen schwere steine zwischen die zweige, so werden sie schwer tragen. $M D V 207$ 
TREES.

1083. Wąnn di bēm im Horning dik mit eis sin gebts fil frucht. (Lnc)

A thick coating of ice on trees in February foretells much fruit.

1084. Wạnn di bēm winters mit eis sin gebts ftl ōbscht 's nēkscht jōr. (Af; Heidelberg)

An ice storm in winter foretells a large fruit crop.

1085. Wạnn di bēm blìe in de dunkle nạchte gebts ken öbscht. $(Y)$

If trees blossom in the dark of the moon they will not bear fruit.

1086. Wạnns zū fil in di blit reğert gebts ken ōbscht. (C, $L b, L n c, M r, M t, N a, S c)$

There will be no fruit if there is much rain during the time when the fruit trees are in blossom.

1087. Es gebt ken öbscht wanns in di blit we'derlēeht. (Be, $B u, D, L h, M t, N u, S c, S n)$

There will be no fruit if there is any lightning during the time when fruit trees are in blossom.

Blitzt es in die baumblüte, so fürchtet man für das gedeihen des obstes. $Z f V$ 1894. 82

1088. Der si’ђet Mærz schneit mern wip ạb fun jēderm båm un schmeisst si wek, nō gebts sell jōr fil ōbscht. (Be, $D ;$ Freiburg)

Cut a twig from each fruit tree on the seventh of March, throw it away and the trees will bear well.

1089. Bēm dråğe besser wạmmern schtrō'sēl um der schtamm binnt. $(A f)$

Trees will bear more fruit if a band of straw is wrapped round the trunk.

Am Christabend oder auch in der Neujahrsnacht umwickeln die bauern mit einem strohseil ihre obstbäume. $M$ DV 206 


\section{BEES}

1090. Di Grischdåknacht zwische elfe un zwelfe wærn di ime leђen'dich un gradle haus am ke'bich rum, 's macht nix aus wì kalt as es is. (Be,C,D,Lh, Lnc, $\mathrm{Mr}, \mathrm{Na}, \mathrm{Sn}$; Freiburg)

On Christmas night between eleven and twelve, bees lose their numbness and crawl on the outside of the hive, no matter how cold the weather may be.

1091. Di Grischdåknacht zwische elfe un zwelfe gradle di ime au'sewennich a am ke'bich rum. (Be, $N a, L n c$, $S n)$

On Christmas eve between eleven and twelve bees crawl about on the outside of the hive.

1092. Der ìmekærb muss mer mūbe, un wanns juscht pår zoll is, wann ēns schtærbt oder di îme sin nix mē wǣrt. $(B u)^{\prime}$

Move the bee hive, even if only a few inches, immediately after a death in the family, or else the bees will be worthless.

1093. Uf der zwē un zwann'zichscht Fe'beweri soll mer net fum seine ēgne grund $g \mathrm{e}^{-}$schunscht gēn em di ìme fært. $\quad(B e, B u, C, L h, S c)$

If you leave your premises on February 22 (St. Peter's) you will lose your bees.

Am Lichtmess darf der bienenvater nicht verreisen und nicht aus dem hause gehen, sonst fliegen im frühling die schwärme fort. $W u 428$

1094. Wann di îme in der wök schwærme, gebts fil hunich in seller kaschte. $(B u, C, L h, L n c, N a, N u, S n$; Heidelberg)

If bees swarm in Libra they will gather much honey. 
1095. Wąmmer tme fạsst ạs schunscht ærğets beikumme hot mer glik. $(B e, S c, Y)$

It is good luck to be able to hive a strange swarm of bees.

It is good luck to have a strange swarm of bees settle in your garden or to find one. $V S L 2.17$

1096. De ìme muss mer di leicht å $\sim$ såğè oder si sin nix mẽ wæ̃rt. $\quad(L h, N u, S c, Y)$

A death in the family must be announced to the bees or they will be worthless.

Der tod des hausherrn muss den bienen angesagt werden, sonst gehen sie ein. Die stöcke werden mit flor behängt. Alem 20. 285

Bees have to be informed of the death of their owner. $D$ E C 204

1097. Wạmmern lēb brot 's un'nerscht seઈerscht lēkt un schtekt nō en butschermesser nei , gēne di ime net fært i'berm schwærme. (Bu; Freiburg)

When bees swarm they will not leave your premises if you run a butcherknife into a loaf of bread that is turned upside down.

1098. Wạn di íme schwærme un wolle fært macht mer en gotterbærm'lichi zucht oder schísst nei ${ }^{\sim}$, nō henke si sich dehēm' añ en båm. ( $B e, B u, L h, M t)$

Bees will settle on a tree at home if you make an outlandish noise or shoot into the swarm.

Schwärmt ein immen, so wird mit gieskannen, pfannendeckeln, blechen aller art ein höllischer lärm gemacht; einmal, um den schwarm zum niedersitzen zu bringen, sodann um die nachbarsleute von dem rechtlichen anspruch an den schwärmenden immen in kenntnis zu setzen. $V A S 1.126$

The instruments used for bringing down a swarm of bees are generally the frying-pan and one of the house doorkeys. D Eng 124

1099. Wanndr di ime net wolle, schtēlscht dern schwærm. ( $B u, C, D, L b, L h, L n c, M r, N u, S c$; Kaiserslautern) Steal a swarm of bees to make your bees thrive. 
1100. Wąnn em en ìm schtecht, gēt si dōt. (Af)

$A$ bee dies after stinging.

Ihr eigener stich verursacht der biene den tod. M $D V 216$

1101. Wămmer der och'tem hạlt wạn em di hummle nõ gēne schteche si em net. $(B e, C, D, L h, L n c, M r$, $\mathrm{Mt}, \mathrm{Na}, \mathrm{Nu}, \mathrm{Sc}, \mathrm{Sn}$; Kaiserslautern)

Bumblebees will not sting you if you hold your breath while they are pursuing you.

1102. Mær dut bē'king sōde ąn en hummle nescht, nō schteche di hummle seller mūnet net. $(B u, M t)$ Put baking soda on a bumble bee's nest and the bumble bees will not sting all month. 


\section{SNAKES}

1103. Wąmmern schląng sēnt såkt mer: "ferfluch'ti schląng", nō kạnn si net fært. ( $L h)$

When you see a snake you should say "cursed snake" and it cannot move.

Gott hat alles erschaffen, und alles war gut,

Als du allein, schlange, seiest verflucht;

Verflucht sollst du sein und dein gift.

Zing, zing, zing. Hoh 35

1104. En hærnschląng hot en hærn im schwąnz un wạs si mit sellem schwanz schtecht gēt dōd un wąnns en båm is. $(\mathrm{Be}, \mathrm{Lh}, \mathrm{Na})$

A horned snake has a deadly horn in its tail, for anything struck by that tail will die even though it be a tree.

1105. Wūn schlann'ge htter is sin å schlange um de wēk. $(B e, L h)$

Wherever there are dragon flies there are snakes.

1106. Es gebt en sært schlange ąs mer rēfschlange hēst. Si schteke der schwanz ins maul un schpringe wi en ring, un wass si dreffe gēt dōd. $(B e, L h)$

There is a species of snakes called hoop snake. It puts its tail into its mouth and runs like a hoop, and anything hit by it will die.

Das sind die ringelschlangen. Hlbg.

1107. Wạmmern schlang ferbrennt dreibts di schlange aus. (Lb, Mt, $Y$; Kaiserslautern)

Burning a snake will drive out snakes.

1108. Alte dischlumbe ferbrenne halt di hausschląnge wek. $(C, L n c, N a, S c)$

Burn old dish cloths to drive out garter snakes.

Man muss all die alten lumpen verbrennen, die es in der küche gibt. Hlbg. 
1109. Wū alte schū ferbrennt wærre bleibe ken schlange um de wēk. (Be, Bu,C,D,Lh,Lnc, $M r, N a, S c, Y$ ) Burning old shoes will drive out snakes.

1110. Wanmmer zwible im ho'sesak nōdråkt oder di bē reibt mit zwible, beise em di rassselschlange net. $(C$, $L h, M r, S c)$

Rattle snakes will not bite you if you have onions in your trousers pocket or if you rub onions on your legs.

Am 25. Jänner soll man ein Göimacht brot und knoblauch essen, dann wird man im Jahre von schlangen nicht beschädigt. $\quad Z 1163$

1111. En schlang gēt net dōd bis di sunn unner is. (Af; Heidelberg)

A snake will not die before sunset.

Snakes when scotched will live till sundown. V S L 2 . 601 


\section{WEATHER}

1112. Wąnns schpōtjōrs å fạngt schnēe såkt mer: di blō. bær'ger roppe gens. $(L h)$

When it begins to snow in fall, you say: the people along the Blue Mountains are plucking geese.

Wann es schneit, sagt man: Dem federmann ist der sack aufgebrochen. $V A S 1.198$

1113. Wạnn di grēn'åge wē dūn gebts wîscht wetter. (Af) Aching corns are a sign of rain.

Das schmerzen der hühneraugen bedeutet regenwetter. $Z$ 996.

Pricking corns are a sign of rain. $F B$ 3. 215

1114. Wạnn der wipperwill' greischt gebts reğe. (Mt) The cry of the whippoorwill presages rain.

1115. Sō fill dåk âs es sin fum êrschte schnē bis folllicht, sō fill schnē gebts ime winter. $(B u, D, L b, L h, L n c$, $M t, N a, N u, S c, S n, Y$; Freiburg)

The number of snows during winter is indicated by the number of days from the first snow in fall to the next following full moon.

1116. Wạnn di hinkel sich im Ågu'scht mause gebts en hærter winter, im Oktober en leichter. $(B u, C, M r$, Sc)

If chickens moult in August, winter will be severe; in October, mild.

1117. Wann di hinkel fe'driche bē un fìs grì̆ge bedeits en hærter winter. (Af; Heidelberg)

If the lower legs of chickens are well covered with feathers, the winter will be severe.

1118. Sō fil dåk ă noch sin fum ērschte schnē bis zum end fum mūnet, so fil schnē gebts seller winter. ( $L h$, Lnc, Sn) 
The number of days between the date of the first snow and the end of the month indicates the number of snows during the winter.

1119. Gríne Grischdåk, weise Ōschtrē. (Af; Heidelberg) Green Christmas, white Easter.

1120. Wănn di hinkel sich fanne 's ërscht mause is der förwinter hært; wannn hinne, der nōchwinter. (Be, $L b, L h, L n c, M r, N u, S c, S n, Y$ )

If chickens moult first on the fore part of their body, the early part of winter will be severe; if on the rear, the end of winter.

1121. Wănn di Mæri'che druke iber der bæ'rik gēt (der zwet 'Tschulei') is es sex woche druke. ( $A f)$

If it is elear on the Visitation of the Virgin there will be no rain for six weeks.

Geht Maria übers gebirg bei sonnenschein,

So wird der Juli trocken sein.

Tritt aber an diesem tage regenwetter ein,

Drauf wird es unbeständig noch vier wochen sein. $Z 1384$

1122. Die Mæri'che gēt i’toer der bæ'rik, tr schweschter bsuche. ( $B e, B u, D, L h, N a, S c, Y)$

The Virgin erosses the mountains to visit her sister.

1123. 'Wănn di Mæri'che năss i'toer der bæ'rik gēt (der zwet Tschulei') gebts ken keschte. (Be, Bu, D, Lh, Mt, $\mathrm{Na}$; Heidelberg)

If it rains on the Visitation of the Virgin the chestnut crop will be a failure.

1124. Wạnn di Mæri'che nạss ítoer der bæ'rik gēt (der zwet Tschulei') kummt si druke zurik' (der fuf'zēt Ågu'scht) un wann si druke ni'toer gèt, kummt si nass zuri'k. (Af)

If it rains on the Visitation of the Virgin (July 2) there will be a dry spell when she returns (Aug. 15) and vice versa.

Wenn es regnet, da die Muttergottes über das gebirg geht, regnet es, bis sie wieder zurückkehrt. $Z \mathbf{Z} 1383$ 
1125. Wănns wetter nạchts ufglört hălts net lạng. ( $A f$; Heidelberg)

If it clears up at night, clear weather will not last long. $C S A 966$

1126. Wū di ērschte gewittere frijōors dærich złğe gēn si 's ganz jōr dærich. (Af)

Subsequent thunderstorms follow the direction of the first thunder storm in spring.

Wie das erste gewitter geht, so gehen alle; es zeigt den weg, den alle gehen werden. A $J 239$

1127. Mer soll zwelf frische zwitle nemme, si nåme, we'nich aushiliche, si nō mit sân fille un uf der gær'ret dråğe un si zwelf dåk drobe leie losse. Di zwible wīs salz drin ferschmolze is hen di nåme fun de nąsse mūnet. $(B e, L b, L h, S c)$

The weather for the year is determined by taking twelve onions, naming them, one for each month, hollowing them slightly and filling them with salt. The wet months of the year are indicated by the onions in which the salt is melted.

In der Christnacht legt man etwas salz in zwölf mit den monatsnamen bezeichnete zwiebelschalen. Wenn morgens viel oder wenig salz in einer schale geschmolzen ist, so bedeutet das den grad der feuchtigkeit des monats. $Z$ f $D$ M 1. 240

1128. Wanns 's ērscht mol schnēt, sō fill schnē gebts a a der då'tum is. (Af; Freiburg)

The day of the month of the first snowstorm indicates the number of snows during the winter.

1129. Wănns uf di Pingschte reğert băde sell jōr di reğe nix. (Lnc)

Rains will not be beneficial if it rains on Whitsuntide.

1130. Wănns uf di Pingschte reğert reğerts sibe Sunndåk. (Lnc, Na)

Rain on Whitsunday is followed by seven rainy Sundays. 
1131. Wanns uf der Him'melfærdåk reğert, bạde sell jōr di reğe nix. $(A f)$

If it rains on Ascension day, rains will do no good for the rest of the summer.

1132. Wạns uf Karfrei'dåk re'ğgert gebts hōcher wind un net fîl hoi. $(S n)$

If it rains on Good Friday, you may look for high winds and little hay.

1133. Wạnns uf Kærfrei'dåk re'ğert, drikle di reğe gråd uf un ba्de nix. $(A f)$

If it rains on Good Friday, rains all summer long will do no good.

Wenn es am Karfreitag regnet, so wird die erde das ganze jahr nicht satt. $W u 72$

1134. Wạnns uf der Kærfrei'dåk reğert, reğerts siøe Sundåk. $(A f)$

Seven rainy Sundays follow rain on Good Friday.

Wenn es am Ostersonntag regnet, regnet es sechs Sonntage nach einander. $Z 1294$

1135. Wạnn di håne o’’̄eds fær nein ūr grēe gebts reğe. $(A f)$

The crowing of cocks before nine at night indicates rain.

Wenn die hähne krähen, gibt es regen. $A J 235$

1136. Wannn di pō'håne greische gebts reğe. (Af)

The crying of peacocks denotes rain.

Wenn die pfauen schreien, gibt es regen. A $J 235$

Peacocks erying much denotes rain. $H 119$

1137. Wannn di pō'håne ó’’eds greische gebts reğe. (Af)

The cry of peacocks in the evening indicates rain.

Wenn die pfauen schreien, gibt es regen. A $J 235$

1138. Wann di eile uf em bæ'rik greische gebts schē wetter; uf de beind, wisschtes. (Sc)

If owls hoot from the hills it indicates clear weather; if from pine trees, disagreeable weather. 
1139. Wạnn di eile greische fær nạcht oder mærğets wann di dåk'helling dō is gebts wíscht wetter. (Lnc)

If owls hoot at nightfall or after daybreak, it indicates bad weather.

1140. Wann di eile ót teds greische gebts reğe. (Af) The hooting of owls at dusk indicates rain.

1141. Wănn di hinkel im reğe rum låfe gebts noch mēner reğe. (Af; Heidelberg)

Chickens walking about in the rain is a sign of more rain.

1142. Wî der finft dåk im mū'net, so is der gannz mū'net. (Y)

As is the weather on the fifth day of the month, so it will be the rest of the month.

Wie das wetter am ersten Dienstag, so ist der ganze monat. $\mathrm{Fr}$

1143. Wî der letscht Freidåk im mũ'net, sõ is der nēkscht mū'net. (Af)

As the last Friday of the month, so the following month. $C S A 940$ :

1144. Wănn en maulwærf grund rausschmeisst, gebts reğe. $(L h)$

The burrowing of a mole is a sign of rain.

Wenn der maulwurf die erde aufwirft, wird schlechtes wetter. $Z 987$

1145. Wanns reğert uf der Tschann Huss (6. Tschulei'), gebts ken nuss. $(D, L n c, S c, S n)$

The nut crop will be poor if it rains on John Huss' day. Regnet's auf Johannistag, so verderben die nüsse und geraten die beeren. $G 3.116$

1146. Hōcher wilder wær'mūt, dîfer schnē. (Af; Heidelberg)

Tall bitterweed (ambrosia artemisiaefolia), deep snow. 
1147. Wănn en ūr mit me messne gschærr fil zucht mącht will si wind hăbe, gebts schtærmisch wetter. $(C$, Lh, Sn; Heidelberg)

If a clock with brass works ticks very loud it is a sign of stormy weather.

1148. Wạnns frì im jōr dunnert gebts en gūt frucht jōr. $(B u, C, L h, M t, N u, S c, Y)$

Early thunderstorms are a sign of good crops.

Donnert es frühe, gibt es ein fruchtbares jahr. $Z 1024$

1149. A "gelofne drink'gleser bedeite wischt wetter. (Af)

When the glass sweats it is a sign of rain. $C S A 1016$

Wenn vom wasser die gläser anlaufen, wird schönes wetter. $Z 1052$

1150. Wănn di hinkel $æ^{\prime}$ rik schpringe wånns å făngt reğere schtopts glei. (Af; Heidelberg)

If chickens run for shelter when it begins to rain, the rain will not last long.

1151. Wămmer wund- oder gliderschmærze hot gebts wíscht wetter. $(A f)$

Pain in a scar or the bones indicates rain.

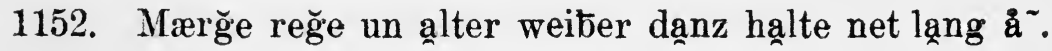
$(A f)$

Morning showers and old women's dancing do not last long.

Morgenregen und alter weiber tanz dauern nicht lang. $Z 1004$

1153. Wănns mærğets fær sibe gewittere hot gebts seller dåk sibe gewittere. $(B e, B u, D, L h, M r, M t, N u, S c$, Y)

If there is a thunderstorm before $7 \mathrm{~A}$. M. there will be seven thunderstorms that day.

1154. Wănns mærğets frł gewittere gebt gebts noch mēner seller dåk. ( $A f)$

Thunder in the morning 
All the day storming. $C S A 980$

Wenn es morgens früh schon ein donnerwetter gibt, so müssen noch mehr den tag kommen. A S 1. 401

1155. Wạn fíl eis is zwische Grischdåk un Neijōr gebts ftl ōbscht. (Af)

Much ice between Christmas and New Year is a sign of a big fruit crop.

1156. Sō lănge eiszânpe às es hot zwische Grischdåk un Neijōr, so dif schnē gebts seller winter. $(C$, Lnc, $M r, M t, N u, S n$ )

The length of icicles between Christmas and New Year indicates the depth of snow during the winter.

1157. Lange eiszapppe fær Neijōr bedeite lạger flax 's nēkscht jōr. $\quad(B u, C, L h, L n c, M r, M t, N u, S n, Y)$ Long icicles before New Year indicate long flax next year. Lange eiszapfen am hausdache im winter vor neujahr bedeuten langen flachs für das nächste jahr. $B S 33 . p$ 127

1158. Wạns lạnge eiszappe hot uf di Fåsenacht gebts langer flax sell jōr. ( $\mathrm{Be}, \mathrm{C}, \mathrm{Lh}, \mathrm{Lnc}, \mathrm{Mr}, \mathrm{Na}, \mathrm{Nu}$, Sn, $Y$; Heidelberg)

The length of icicles on Shrove Tuesday indicates the length of the flax that year.

1159. Wann en $\bar{u}$ 'mens grund raus schmeist gebts reğe. $(\mathrm{Na}, \mathrm{Nu})$

Ant hills are a sign of rain.

1160. Wann di amschle $æ^{\prime}$ rik singe is es sein fer reğe. $(L n c, N u)$

If robins sing merrily, it is a sign of rain.

Wenn der fink schreit, gibt es regen. $A J 235$

1161. Wạnn der schmōk gråd in di hē gēt gebts glōr wetter å̄ber wanner sō uf em bo'dem naus grądelt gebts wischt wetter. (Af)

Smoke, rising, is a sign of clear weather; falling, of rain. Wenn es den rauch stark niederdrückt, gibt es regen. $A$ $J 235$ 
1162. Wạnns reğert wạnn di sunn scheint gebts drei dåk reğe. (Be, $D, L n c, S n, Y$; Heidelberg)

Rain falling while the sun shines indicates rain for three days.

1163. Es reğert uf der Kærfrei'dåk un wannns juscht drei droppe sin. ( $\mathrm{Be}, \mathrm{Lb}, \mathrm{Lnc}, \mathrm{Na}, \mathrm{Y}$ )

There will be rain on Good Friday, even if only three drops.

Am Karfreitag scheint nicht die sonne, weil an diesem tage Christus gekreuzigt worden. $Z 1275$

1164. Uf der finft Tschulei' reğerts gǣrn. (Be, $L h, N a)$ It usually rains on July 5 .

1165. Wạnns mærğets en re'ğebōğe hot gebts schtærm; ōbeds, glōrts uf. (Mt; Heidelberg)

Rainbow in the morning,

Sailors take warning;

Rainbow at night,

Sailor's delight. $C S A 995$

1166. Wannn di weibsleit låfe gebts reğe. $(\mathrm{Na})$

When many women are seen on the street, it will rain next day. $C S A 1005$

1167. Di alte weiber hen ir schlofkappe haus, nau gebts reğe. (Af; Lenzkirche)

When the old women display their nighteaps, you may expect rain. [Spider webs are meant.]

1168. Wănn schpinneneschter mærğets nąss sin gebts ken reğe. $(B u, M t)$

If cobwebs on the grass are wet in the morning, there is no rain in sight.

1169. Wąnn di schpinne neschter baue gebts reğe. (Af; Freiburg)

Cobwebs on the grass are a sign of rain.

1170. Wann winters di geil dufte gebts geli'nd wetter. (Be, Lh, Na; Heidelberg) 
If in winter horses are covered with hoar frost, it indicates mild weather.

1171. Wann di gens uf'rírisch sin gebts schtærm. (Be, $B u, L b, L n c, S c, S n ;$ Heidelberg)

Restless, noisy geese are a sign of storm.

1172. Wạnn di wilde gens hōch flĭğe wærts wårm; nider, kalt. $(A f)$

If wild geese fly high in the air it indicates warm weather; if they fly near the ground, it will be cold.

Fliegen die schwalben hoch, bedeuten sie gutes wetter; fliegen sie nahe am boden, kommt regen. $Z 757$

1173. Gewittre im herbscht, wårm; im frìjōr, kąlt. ( $L b$, Lnc, Sc, $Y$; Heidelberg)

Thunderstorms in fall are followed by warm weather; in spring by cold.

1174. Wănns låb 's ērscht fum gi'bel fun de bēm făllt gebts en leichter winter; fâllts 's ērscht nēbe rum, gebts en hærter winter. $(B e, B u, L b, L h, L n c, M r, M t$, $N u, Y$; Heidelberg)

If the tops of trees are bare while the sides are still covered with leaves, the winter will be mild; if the leaves fall first from the sides, the winter will be severe.

1175. Wł di drei ǣrschte hunnsdåk, sō di drei ērschte mūnet im neie jōr. $\quad(B e, B u, L b, L h, L n c, M r, M t$, $\mathrm{Na}$; Heidelberg)

The weather of the first three dog days foretells the weather of the first three months of the new year.

1176. Wạnn di wærm schpōtjōrs hōch haus sin gebts en leichter winter. (Af; Heidelberg)

When earth worms lie near the surface late in fall, the winter will be mild.

1177. Mi'lich wært fill gschwinder sauer wannns gewittre hot wì sō. (Af; Heidelberg)

Thunderstorms cause milk tc turn sour much more quickly. 
1178. Wạnn der grund im Disem'ber ufgēt, gēt.er ąlle mūnet uf. (Af; Heidelberg)

If frost leaves the ground in December there will be a thaw every month.

1179. Wạmmer bis'kạtzē rłcht, gebts gelind wetter. (Bu, $C, L b, M r, S c, Y)$

It is a sign of mild weather in winter if you smell skunks.

1180. Wămmer bis'kạtzēgraut rìcht gebts reğe. $(B u, C$, $M r, S c)$

If you smell skunk cabbage (Symplocarpus foetidus) there will be rain.

1181. Wammer di bis'katze rìcht (schmakt, Lnc, $Y$ ), gebts reğe. $(B e, C, D, L h, M r, M t, N a, N u, S c$; Heidelberg)

If you smell skunks it means rain.

1182. Wąnns milz an re sau dik is gebts en hærter winterạm fe'derschte end en hærter fōrwinter; am hinnerschte, en hærter nōchwinter. (Af; Heidelberg) The thickness of the pancreas of a pig foretells the severity of winter: the fore part for the first half of winter; and the hind part for the second half of winter.

1183. Wạnn en raub an de enner schwærz is, is der å fang uns end fum winter hært; wann di mitt, dạn di mitt fum winter. $(B e, C, L b, L n c, N u, S n, Y)$

The color of the caterpillar foretells the severity of winter: if the ends are black, the beginning and the end of winter will be hard; if the middle, then the middle of winter.

Eine ganz schwarze raupe bedeutet einen strengen winter. Hlbg.

1184. Glątteis im Mærz hēst mern ōbscht schtærm. (Be, $D, L b, L n c, M r, M t, N u, S c, Y)$

If there is an ice storm in March there will be an abundance of fruit.

Wenn es glatteis hat, gibt's kein obst. Hlbg. 
1185. Wąnns uf Aller Heil un Sēl (der ērscht un der zwet Nofem'ber) schē is bleibts noch sex woche schē ; is 's wetter åter rau, dann is der winter dō. ( $A f$; Heidelberg)

If the weather is fine on All Saints and All Souls there will be six more weeks of fine weather; if however it is cold and raw, winter is at hand.

1186. Wạnn en drē ærğel gēt gebts reğe. (Be, Na; Heidelberg)

When you hear a grind organ it means rain.

1187. Wạnns bạscht åm we'lschkærn dik is, gebts en hærter winter; wannns welschkærn zum ba्sscht raus wạxt gebts en gelinder. $(A f)$

Thick husk on corn foretells a hard winter; if the husk is so short that the ears protrude, the winter will be mild.

1188. Wạnns in en re'ğgeboğge reğert, gebts drei dåk reğe. $(A f)$

If it rains while there is a rainbow there will be rain for three days.

Ist ein regenbogen, bleibt lange schlecht wetter. $Z 1010$

1189. Wạnn di sunn wạnsser zìkt gebts wíscht wetter. (Af) There will be a change of weather if the sun draws water. Wenn die sonne wasser zieht, wird schlechtes wetter. $Z$ 994

1190. 'Wạn der re'ğefoğel greischt gebts reğe. (Af) The call of the rain crow (or American cuckoo, cocyx americanus) indicates rain.

Wenn der Wangener Gott, so nennt man auf dem Ritten den baumhacker (specht) schreit, regnet es bald. $Z 972$

1191. Wạnn en låbfrosch greischt gebts reğe. (Af) The call of the tree frog indicates rain.

Regenanzeichen ist es, wenn der laubfrosch schreit. $A J$ ...235 
1192. Schíbt der Jạkōbus (der finf un zwąnzichscht Tschulei') weise wolke in di hē, so gebts im winter heifich schnē. (Lh, Lnc, Mr,Sn, Y)

Cumulus clouds on Jacob's day (July 25) foretell deep snow in winter.

25. Juli. Der vormittag des Jakobitages bedeutet die zeit vor Weihnachten, und der nachmittag die zeit nach Weihnachten, woraus man sehen kann, wie die witterung sein werde. $Z 1390$

1193. Wănn di grạbe hōch in der hē sin gebts schtærm. (Bu)

Crows flying high foretell storm.

Wenn die krähen hoch fliegen, gibt es regen. $A J 235$

1194. Wann gens dike feine fedre hen gebts en hærter winter. $(B u, M t$; Heidelberg)

Heavy down on geese foretells a hard winter.

1195. Wạnns reğert uf Quătem'ber gebts ēn'unzwanzich dåk reğe. (Lb, $Y$; Heidelberg)

Rain on an Emberday is followed by three weeks of rain.

1196. Wănns drei dåk reğert fær Quạtem'ber is es drei mūnet nass; wanns druke is is es drei mūnet druke. ( $L b, S c, Y$; Heidelberg)

The weather three days before Emberday foretells the weather for the next quarter.

1197. Wănns fî̀ schpōtjōrs in re drupp wët gebts en hærter winter. $(B e, D, L n c)$

If in fall cattle graze close together, there will be a severe winter.

1198. Wạn di raube schpōtjōrs schpōt haus rumgrądle gebts en leichter winter. (Lh; Heidelberg)

If caterpillars are seen late in fall the winter will be mild.

1199. Wạnn di schōf en diker belz hen gebts en hærter winter. (Be, Bu, D, Lnc, Mt, Sc,Sn, Y; Heidelberg)

Very heavy fleece on sheep indicates a hard winter. 
1200. Wạnn gewittre un'nergēn un kumme wider zurik', kumme si hært. $(B u, M t)$

If a thunderstorm passes and returns, the storm will be terrific.

....dann kommen sie viel heftiger wie so. Hlbg.

1201. Hēser summer, kạlter winter. (Af; Heidelberg)

A cold winter is followed by a hot summer, and vice versa. $C S A 957$

1202. Wănns mærğets ne'blich is un der ne'bel gēt in di hē, gebts ball reğe; wănn er făllt, gebts en schēner dåk. $(\mathrm{Be}, \mathrm{Lh}, \mathrm{Na})$

If morning fog rises, it will rain before the day is over; if it falls, the day will be fine.

Steigt morgens der nebel, gibt's regen;

Sinkt er morgens, wird's schön. $Z 1429$

1203. Wănn der wind îtber di hậter schtobble blōst gēts em schpōtjōr zū. (Be,Lh; Heidelberg)

Cold weather comes after the wind has blown over the oats stubble. $C S A 935$

1204. Dunner i'ber der blote wald, kalt;

Dunner i’ber der grîne wăld, wårm. ( $B e, L b, N a$, $S n, Y$; Heidelberg)

Thunder while the trees are bare is followed by cold weather; when the trees are green, warm.

1205. Wạmmer ălles esst a as uf em disch is, såkt mer als: "es gebt gūt wetter." ( $A f)$

If you eat all the food on the table, the saying is: "There will be fine weather."

Wenn die auf den tisch gebrachten speisen rein aufgegessen werden, gibt es am anderen tag gut wetter. $B S$ 33. 135

1206. Wămmer di trēn weit hērt gebts wìscht wetter, ge. mē'nerhañ d reğe. $(\mathrm{Be}, \mathrm{Lh}, \mathrm{Na})$

If you hear trains at great distances it is a sign of bad weather, usually rain.

Eine änderung der witterung tritt ein, wenn't hellhörig is. $R A 297$ 
1207. Wănn di mike å henkisch sin gebts reğe. (Lh, Lnc, $\mathrm{Nu})$

If flies are exceptionally annoying it is a sign of rain.

Sind die blinnen flei'n sehr blutdurstig, so gibt's bald regen. $R A 297$

1208. Wănns blōse uf wăsser gebt wănns reğert reğerts drei dåk. $(M t)$

If you see large bubbles on water while it is raining, it is a sign of three days of rain.

Stehen während des regens grosse blasen auf den pfützen, dann regnet es noch drei tage hintereinander. $R A 297$

1209. Wann der himmel dik foll schtærne is gebts der nēkscht dåk reğe. $(D, L n c, Y)$

If the stars are remarkably clear and bright there will be rain next day.

Wenn die sterne recht funkeln, ist es ein regenzeichen. $A J 235$

When stars twinkle much or when they look near, a change of weather is looked for. $F B 2.473$

1210. Wạnn di felder en gạner winter mit schnē zū sin gebts en gūti ǣrn. (Be, Lh; Heidelberg)

If the fields are covered with snow all winter there will be good crops next year.

Abundant wheat crops never follow a mild winter. $F R$ 4. 132

1211. Wăn winters di bēm un ąlles dik gereift sin gebts geli'nd wetter. ( $\mathrm{Be}, \mathrm{Lh}, \mathrm{Na}$; Heidelberg)

A heavy hoarfrost is always followed by mild weather.

If hoarfrost continues for two days, it commonly ends the third day with foul weather. $F B 2.480$

1212. Wann der Insching [or Insch] 's pul'fer hærn an der mūnd henke kann gebts glōr wetter. $(B u, M t)$ When the Indian can hang his powder horn on the moon, the weather will be clear. $C S A 991$ 
1213. Wąnn der mūnd un'nerschich schtēt gebts reğe. (Af; Heidelberg)

If the horns of the moon are turned downwards it is a sign of rain.

When the horns of the moon turn down, the moon holds no water, like a basin, and then it comes down. D Eng 39

1214. Wạnn der mūnd uf em bukel leit gebts di nēkschte drei dåk ken reğe. (Lb, Lnc, Na, Sn, Y; Heidelberg)

If the horns of the moon turn upwards there will be no rain for three days.

When the horns of the moon turn upwards there will be no rain. D Eng 39

1215. Wann di sei rumschpringe un hen holz im maul gebts ball schtærm. (Bu, C, D, Lnc, Mr, Mt, Sn, $\mathrm{Y} ; \mathrm{Hei}$ delberg)

If hogs run about with pieces of wood in their mouths, it foretells storm.

In Ireland, to see the pigs running about the farmyard with straws in their mouth foretells an approaching storm. D Eng 116

1216. Wann en katz uf der seit leit un drēt der kopp e'torschich wærts windich. $(B e, C, L b, L h, L n c, N a, N u$, $S c, S n, Y)$

A eat lying on its side and turning its face upward foretells stormy weather.

There is scarcely a movement of the cat which is not supposed to have some significance. D Eng 106

1217. Wann der hund sich uf der bukel lēkt gebts schtærm. $(C, S c)$

A dog lying on its back indicates stormy weather.

If dogs roll on the ground and scratch or become drowsy and stupid, a change in the weather may be expected. D Eng 103 
1218. Der zwet Hær'ning is Grund'sau dåk. Wąnn di grundsau îr schânte sēnt gēt si zurik' in tr loch un es is noch sex woche kaltt; wann si en åtber net sēnt is es frìjōr. $(A f)$

February second is Groundhog day. If the groundhog sees its shadow it returns to its lair and winter will continue for six weeks; if it does not see its shadow, spring is at hand.

Am Marialichtmesstag kriecht der bär, der fuchs oder der dachs aus seinem loch. Sieht er dann die sonne früh aufgehen, kehrt er um und kriecht um vierzig tage wieder hinein. Ist aber ein schlechtes wetter, bleibt er vorne an der höhle, denn es wird ein "frühes" jahr. $Z 1176$

If the weather on Candlemas Day, Feb. 2, be bright and clear, there will be a long continuance of cold wintry weather. $H 107$

1219. Nasser Abril' un kîler Moi

Fillt keller un scheier un bringt ftl hoi. $(B u, C, D$, $M t, N a, N u, S c, S n, Y$ )

A wet April and cool May

Fills cellar and barn and brings much hay.

April warm, Mai kühl, Juni nass,

Füllt dem bauer scheuer und fass. $Z 1307$

A cold May is kindly

And fills the barn finely. $H 111$

1220. Drukner Abril', nassser Moi

Bringt en scheier foll hoi. (Af)

A dry April and a cool May

Fills the barn with hay.

A dry May and a rainy June

Puts the farmer's pipe in tune. $H 112$

1221. So fil nētel im Jener, so fîl reife im Moi. ( $L b, L h$, $\mathrm{Mr}, \mathrm{Na}, \mathrm{Sc}, \mathrm{Sn}$; Heidelberg) 
The number of fogs in January deternines the number of frosts in May.

As many mists in March, so many frosts in May. H 109

1222. Wann der Mærz rei kummt wi en lạmm gët er naus wì en lēb. ( $A f ;$ Heidelberg)

If March comes in like a lamb, it goes out like a lion.

If March comes in like a lion, it goes out like a lamb and vice versa. H 108

1223. Wănn di grăbe greische gebts reğe. $(C)$

The cawing of erows indicates rain.

Crows cawing louder than usual is a sign of rain. $H 118$

1224. Wănn deichle schwitze gebts reğe. (Af)

The sweating of water pipes is a sign of rain.

Wenn brunnenröhren schwitzen, regnet es bald. $Z 992$

1225. Wąnn di schtē $\overline{\mathrm{T}}^{\sim}$ schwitze gebts reğe. $(B u)$

The sweating of stones indicates rain.

The sweating of stone pillars denotes rain. $H 118$

1226. Wạnn di grạbe nider fliğe gebts wēch wetter. ( $N a$, Sc; Freiburg)

When crows fly close to the ground it indicates mild, i. e., wet weather.

If a heron or bittern flies low the air is becoming charged with vapor. $H 118$

1227. Mer dærf net noch me gewitter oder an der himmel mit em finger weise. $(B u, L b, L h)$

You must never point your finger at a thunderstorm or at the sky.

Wer mit dem finger auf ein wetter deutet, den verschlägt es, denn der finger zieht das wetter an. $V A S 1.193$; ef. $G 3.334 \& B S 33.185$

It is ill luck to point at the quarter of the heavens where lightning is expected to come from. $V S L 2.178$

1228. Wănn di sunn Freidåk ōbeds drìb unnergēt, reğerts Sunndåks. (Lnc) 
If the sun sets in a cloud on Friday evening, it will rain on Sunday.

A rainy Friday, a rainy Sunday;

A fair Friday, a fair Sunday. $D$ Eng 242

$1=29$. Wi' 's wetter fun zēe bis zwē sō is es der ganz dåk. $(B e, D, L b, L n c, M r, S c, S n, Y$ )

The weather between ten and two

Tells what the day will do.

Between twelve and two

You will see what the day will do. Corn 136; CSA 963

1230. Wănns mærğets fær de sibe reğert un di grăbbe greische wærrts iberdem' hell. ( $B e, D, L b, L h, M r$, $M t, N a, N u, S c, S n, Y$; Heidelberg)

If it rains before $7 \mathrm{~A}$. M. and the crows are cawing, it will soon clear off.

1231. Reğe fær sibe, glör fær elfe. $(C, D, L h, M r, S c)$

Rain before seven, clear before eleven. $G S \cot 154 ; C S A$ 965

Regnet's vormittag, so wird nachmittag noch besser wetter. G 3.826

1232. Wann der mūnd eter'schich schtēt gebts glōr wetter. (Af; Heidelberg)

The horns of the moon turned upward indicate clear weather.

When the new moon has her horns upward she is said to be "on her back" and it is commonly believed to betoken fine weather. $E Y 45$

Should the new moon lie on its back, it is a sign it will be dry that month, for the moon would hold water. $C S A$ 991

1233. Dēl leit kenne såğe wạs fer wetter ăs es der nēkscht winter gebt wann si der bruschtgnoche fun re gans sēne. $(B e, L h)$

Some persons can predict the weather of the coming winter from the breast bone of a goose. 
If the breast of the roast goose when held up to the light shows dark upon the whole rather than otherwise, wo shall have a severe winter throughout; if mottled variable, the lighter aspects betokening snow, the darker, frosts. The general transparency of the bone denotes an open winter, the front part foretelling the state of that season before Christmas, the inner part the weather. after Christmas. $\quad C F$ Y 2.70

1234. Wạnn di kạtz grås fresst gebts bạll reğe.

If a cat eats grass, it is a sign of rain.

Wenn die katze gras frisst, regnet's bald. $V A S 1.117$

1235. Fìl hi'kerniss, hán'selniss, walniss un keschte bedeite en hærter winter. $(B e, B u, L h, M t)$

An abundant crop of shellbarks, hazlenuts, walnuts and chestnuts foretells a severe winter.

Viele haselnüsse deuten auf einen strengen winter. $W u$ 207

When there was an abundant crop of wild fruits there was to be a severe winter. G S Scot 148

1236. Wănn di håne uf der fens hoke gebts reğe. ( $A f$; Heidelberg)

If roosters sit on a fence it is a sign of rain.

1237. Wănns uf der fîrt Tschulei' reğert wærn di keschte wærmich. $(S n)$

If it rains on July 4, chestnuts will be wormy.

1238. Wănns uf di Pingschte reğert, gebts ken keschte. (Bu)

Rain on Whitsundays means no chestnuts.

Regnet's auf Johannistag,

Ist's der haselnüsse plag. $Z 1361$

1239. Wạnns reğert uf der si'berschlēfer gebts ken keschte. (Be, C, Lh, Lnc, Mt, Y)

Rain on Seven Sleepers (June 27) means a poor chestnut crop.

Wenn es am Siebenschläfer, 27. Juni, regnet, so regnet es sieben tage oder sieben wochen lang hintereinander. R A 297 
1240. Wạnn der hund grås fresst gebts bạll reğe. (Af) If a dog eats grass it means rain.

Fressen die hunde gras, so gibt's bald regen. $R A 297$

A dog eating grass prognosticated rain. $G$ Scot 127

1241. Wạnn di sunn Mittwochs drìb un'nergēt reğerts bis Sunndåk. (Af; Heidelberg)

If it is cloudy at sunset on Wednesday it will rain before Sunday.

1242. Wănn di sunn Mittwochs hell un'nergēt, gebts ken reğe fer Sunndåk. $(B e)$

A clear sunset on Wednesday means clear weather till Sunday.

1243. Wạnn di sunn Dun'nerschdåks drìb un'nergēt reğerts Sunndåks. (Bu,C,Lh, Mr, Mt, Nu,Sc,Sn; Heidelberg)

If it is cloudy at sunset on Thursday evening it will rain on Sunday.

1244. Wạnns Sunndåks dríb is reğerts fer Mittwoch. (Af; Heidelberg)

If the sun sets in a cloud on Sunday it will rain before Wednesday.

1245. Wannn di sunn Sunndåks drìb un'nergēt reğerts fer Mittwoch. (Bu, D, Na, Nu,Sc,Sn; Freiburg)

If it is cloudy at sunset on Sunday you may expect rain before Wednesday.

1246. Wănns uf di Pingschte reğert reğerts sibe Sunndåk hen'drann. (Af; Freiburg)

If it rains on Whitsunday it will rain on the following seven Sundays.

1247. Wanns Mittwochs hell is reğerts net fer Sunndåk. $(B e)$

If Wednesday is clear it will not rain before Sunday. 
1248. Wạnn der münd en ring hot gebts reğe oder schnē. $(A f)$

A dise around the moon indicates rain or snow. $G$ Scot $152 ; C S A 995$

Hat der mond einen hof, kommt regen. $Z 980$

1249. Wănn en ring um der mūnd is, sō fil schtærne âs drin sin, so fill dåk is es noch schēe A circle around the moon means rain, and the number of stars inside the circle denotes the number of days until it will rain. $C S A 996$ 


\section{MOON}

1250. Im dunkle mūnd kērt mers haus aus, nō grikt mer ken schåbe oder schpinne. (Be, D, Lb, Lnc, Mr, Nu, $S c, S n)$

Sweep the house in the dark of the moon and you will have neither moths nor spiders.

Wenn man das haus bei neumond reinigt, kommen spinnen ins haus. $W u 58$

1251. Wạmmer fens marcht im iちerschtēende gfrtrt si raus. (Af; Heidelberg)

Fences built when the horns of the moon turn up will freeze out of the ground.

1252. Wạmmern dạch schindelt muss mers im un'nerschtēende dũ ${ }^{\sim}$, nō bleibe di schindle gråd uf em dạch; im i'berschtēende drēe si sich uf ; mit bōrd'wåks is es 's sēm. (Af; Heidelberg)

Shingle the roof in the decrease of the moon, so that the shingles are put on when the horns of the moon are turned up, and they will warp and rise up. The same thing holds true of board walks.

1253. Wann der mūnd uf em scheint nachts im bett wært mer nær'risch. (Lh, Lnc, $M r, N u, S n, Y$ )

You will go crazy if the moon shines on you in bed.

Scheint der mond auf ein ungetauftes kind, wird es mondsüchtig. $G$ 3. 1034

1254. Di grē'nåğe [oder grē åğe] schneit mer im a्रbnemmede ab. (Af; Heidelberg)

Corns should be cut in the wane of the moon.

1255. Im nei'mūnd schneit mer di fingerneğel ă fer gūt glik. (C, Lnc, $S c, S n)$

Cut fingernails in new moon for good luck. 
1256. Im neie licht soll mer di fingerneğel ghbschneide, zå̃ wẽ zu ferhite. (Be, Bu, Lh, Lnc, Mr, Na, Nu, Y; Heidelberg)

Cutting fingernails in new moon prevents toothache.

1257. Kạ́na ådå dischtle ås im Lēb im Agu'scht a ab'kakt wærn, schlăğe nimmi aus. (Be,C,Lh,Lnc, $M t, \hat{N} a$, Sc, $Y$ )

If Canada thistles are cut in August in the sign of Leo, they will not sprout again.

If brush and thistles are cut down in the full moon in August when the sign is in the heart, they will never grow again. C S A 1125

1258. Gschmōkt flēsch soll mer im lēre licht aus em schmōk nemme nō gebts ken wærm drå̃. $(B e, C, D, L b, L h$, $\mathrm{Mr}, \mathrm{Mt}, \mathrm{Na}, \mathrm{Sc}, \mathrm{Sn}, \mathrm{Y}$ )

Smoked meats should be taken out of the smoke house in the dark of the moon to prevent them from becoming wormy.

Die schweine werden im abnehmenden mond geschlachtet, damit der speck nicht von ungeziefer heimgesucht werde. Alem 25. 51

1259. Es flēsch fun fî̀ oder sei ăs im zu'nemmede gschlącht wært schnærrt net sō wìscht ei i iøerm koche oder brōte oder wạmmers ei salat un schmōkt. (Af; Heidelberg)

The meat of animals killed in the increase of the moon will not shrink in the pot or in curing.

If a pig is killed in the wane of the moon, the bacon will not smell and the meat be unwholesome. V S L 2.1. 244

Kill any animal for meat in the increase of the moon and it will increase in the pot. $C S A 1127 ; W u 450$

1260. Wạmmerm neimūnd geld weist, grikt mer mē. (Be, $D, L n c, M r, N a, N u, S n)$

Show the new moon money and you will have more. 
Wer kein geld hat, hüte dass ihm der neumond in den leeren beutel scheine, sonst leidet er den ganzen monat geldmangel. $G 3.107$

Money in the pocket must be burned when the first sight of the new moon was eaught. $G S \cot 151 ; C S A 1101$

1261. Wannn der mūnd uf em scheint im bett, ferzikts ems gsicht. $(D, L h, L n c, Y)$

Your features will be distorted if the moon shines on you while asleep.

Man soll die bettlade nie so stellen, dass der mond dem schlafenden ins gesicht scheint, weil man nicht gut schläft. $\quad V A S 1.188$

It was looked upon as dangerous to sleep with the moon shining on the face, for the whole face, particularly the mouth, became twisted. G Scot 152

1262. Wănn der mūnd uf fisch oder flēsch scheint wærts gråd schtinkich. (Bu,Lb,Lh,Lnc)

If the moon shines on fish or meat, they will spoil.

Fish hung in moon light was supposed to acquire poisonous properties. GS Scot 1112

If the moon shines on fish, they will spoil. $C S A 1112$

1263. Wămmer der neimūnd 's ērschtmol sünt iber di links schulter bedeits unglik. ( $B e, B u, C, D, L b, L h, L n c$, $M r, N u, S n, Y$; Heidelberg)

Seeing the new moon for the first time over the left shoulder is unlucky.

To see the new moon over the left shoulder is unlucky. $V S L 2.182$

1264. Fense mącht mer im unnerschtē ende. (Af; Freiburg)

Build fences when the horns of the moon are turned down.

1265. Wănmmer sich di zēe neğl im ufgēende anb'schneit, waxxe di neğl ins lëbe. $(B u, D, L n c, M t, S c ; H e i d e l$ berg)

Toe nails cut in the increase of the moon will become ingrown. 


\section{SIGNS OF THE ZODIAC}

1266. In der Wōk dut mers flēsch aus em schmōk. (Af; Heidelberg)

Meats should be taken out of smoke in Libra.

1267. Sauergraut im Fisch ei gemącht wært wąssrich. (Na, Sc; Heidelberg)

Sourkraut made in the sign of Pisces will become watery.

1268. Schōf schērt mer in der Wōk, nō gríğe si ken leis. $(B e, S c, S n, Y)$

Sheep will not become lousy if shorn in the sign of Libra. ...... und die haare wachsen wieder. Hlbg.

1269. Im Lēb dærf mer net schląchte. $(B e)$

No butchering should be done in the sign of Leo.

1270. Im Lèb dærf mer ken flēsch ei־ sălze, schunscht wærts leђen'dich. (Be, Bu, C, D, Lb, Lh, Lnc, Sn, Y)

If meats are salted in the sign of Leo they will become maggoty.

Im Löwen salzt man es ein. Hlbg.

1271. Mær soll net schlạchte ime leßen'diche zēche, schunscht grikts flēsch wærm. $(B e)$

Meats will become wormy if the animals are slaughtered in a living sign.

1272. 'S fł soll mer in der Wōk schląchte, nō wtkts schwēr. $(A f)$

The slaughtered cattle will be heavy if butchered in the sign of Libra.

1273. Im Fisch gēt mer net uf bsuch, 's reğert immer. (Bu; Heidelberg)

Never go visiting in the sign of Pisces, as it always rains then. 
1274. Mer solls flësch net aus em schmōkhaus nemme ime leben'diche zēche schunscht grikts wærm. (Be,Bu, $C, D, L b, L h, L n c, M r, N a, N u, S c, S n$; Heidelberg) Smoked meats should not be taken from the smoke house during a period, the zodiacal sign of which is a living being, to prevent them from becoming wormy as they otherwise will. 


\section{SPECIAL DAYS AND SEASONS}

1275. Heilich wąsser kummt fun Mærze schnē und is gūt fer wēe åğe. $(S n, Y$; Freiburg)

March snow water is holy water and is good for sore eyes.

1276. Im Mærz schneit mer di draube ranke. Sell wassser is gūt fer wēe åğe. (Bu; Freiburg)

Prune grapevines in March. The sap is good for sore eyes.

1277. Wąmmer sei ${ }^{\sim}$ mann sēne will muss mer der schpi'ğel i'ber der brunne hēbe uf Áller Heil un Sēl (der èrscht un zwet Nobem'ber). ( $L b, L h, Y$; Freiburg) If you would see your future husband, hold a mirror over a well on All Saints and All Souls (Nov. $1 \& 2$ ).

1278. Wạmmer Sạmschdåks å fangt en haus bleschtre fallt di bleschtring runner. (Lnc; Heidelberg)

If you begin plastering a house on Saturday the plastering will fall off.

1279. Sis wun'nerselte as Mittwochs en leicht kaltē wærd. $(B u, C, D, L b, L h, M r, S c, S n)$, aber net in Bærks un Ląn'geschter.

Funerals are very rarely held on Wednesday, except in Berks and Laneaster.

Mittwoch und Freitag gelten in Süddeutschland als unglückstage. $M D V 175$

1280. Mittwochs dærf mer net wesche schunscht hot mer ken glik mit em fi. $(B e, L h, N a, S c)$

If Wednesday is washday you will have bad luck with your cattle.

1281. Wạmmer Mittwochs wescht gēn em di sei dōd. (Be)

Your pigs will die if you do washing on Wednesday.

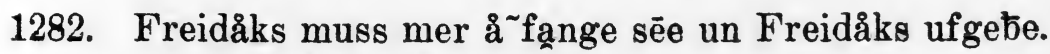
$(B e, L h, L n c, M t, S c, Y$ ) 
Begin sowing of grain on Friday and finish it on Friday. An einem Freitag muss man zum erstenmal einspannen und die ernte beginnen. $W u 61$

1283. Wannd en feind hoscht, gēscht drå und gischt en kuğel uf di Grischdåknacht zwische elf und zwelfe uf me greiz'wēk. Selli kuğel lådscht nō un schísscht si un si drefft dei feind, 's macht nix aus wū er is. $(B e, C, L b, L h, N a, S c, Y)$

Cast a bullet on a crossroad on Christmas night between eleven and twelve. Load it into your gun and it will hit your enemy wherever he may be.

Freikugeln, die immer treffen, giesst man in der Weih. nachtsmitternacht schweigend auf einem kreuzwege. Wu 452

1284. Grischdåk ōbeds zwische elfe un zwelfe muss mer in der kt'schtâll gē wạmmers fi hēre will schwetze. (Af)

Cattle talk between eleven and twelve on Christmas night. In der Christnacht können die kühe sprechen. $Z$ I $D M$ 3. 20

1285. Uf der Him’melfærdåk dærf mer net nēe oders gewitter schlakt em in di scheier. $(A f)$

Lightning will strike your barn if you sew on Ascension day.

In das haus, wo auf Himmelfahrt genäht oder auch nur eine nadel eingefädelt wird, schlägt das gewitter. $G 3$. 703

1286. Uf Him'melfærdåk dærf mer net fåre oder mer hot en unglik. ( $B e, B u, C, D, L b, L h, M t, N a, S n, Y$; Heidelberg)

If you take a drive on Ascension day you will have an accident.

1287. Uf der Him'melfærdåk dærf mer net im grund schaffe. $(B u, C, L b, L h, M r, N a, N u, S c, S n, Y)$ Never till the soil on Ascension day. 
1288. Uf der Him'melfærdåk dærf mer net schaffe oders gewitter schlankt in ènich ebbes ans mer drå schânfft. (Af; Heidelberg)

Lightning will strike anything on which you worked on Ascension day.

1289. Uf der Him'melfærdåk dærf mer nix dū $\sim$ exe'pt fische $\mathrm{ge}^{\tilde{\mathrm{e}}}$. $(B e, B u, C, L h, M t, N a, S c, S n)$

The only thing you may do on Ascension day is go fishing.

1290. Uf der Him'melfærdåk soll mer siøe særte tē drinke, nō grikt mer sell jōr ken ær'blichi grạnket. $(L h, S n)$ By drinking seven kinds of tea on Ascension day you will escape contagious diseases for the rest of the year.

Am Fronleichnamstag......Hlbg.

1291. Uf Neijōrmærğe soll mern brōtwærscht esse sō axs mers ganz jōr schtærik un gref'tich is. $(B e, C, L h$; Nürtingen)

If you eat sausage on New Year's you will be robust all year.

1292. Uf der Piusdåk (der elft Tschulei') hen di schlange ir pik'nik. (Lh)

Snakes have their picnic on Pius' day.

1293. Ōbeds fær Grischdåk soll mer drei særte esse naus ufs fenschter schtelle, un der nēkscht mærğe esst mer nō en maulfoll fun jēdre sært. Wạmmer des dut, grikt mer sell jōr ken fíber. (Lh; Heidelberg) To prevent fevers you should put three kinds of food on the sill outside of the window on Christmas eve, and on Christmas morning you should eat some of each kind of food.

1294. Wammer Mittwochs oder Freidåks fun de hexe schwetzt hēre si 's mitau's mer såkt: seidrek fær di ōre. $(B e, L h, M r)$

If you speak of witches on Wednesday or Friday they will hear you unless you say: pigs' dung for the ears. 
Ehe man über hexen spricht, soll man sagen: "dreck und kot für die ohren!" Sonst können sie einem schaden, wenn man $\mathrm{zu}$ wenig gesegnet ist. $Z 524$

1295. Wammer Mittwochs un Freidåks fun de hexe schwetzt hēre si es mitau's mer duts u'nich seim ēg'ne dach un mer nennt der dåk. $(B e)$

When you talk of witches on Wednesdays or Fridays they will hear you unless you speak of them only under your own roof and mention the day.

On Fridays the fairies obtrusively enter houses and have even the impudence, it is said, to lift the pot to see what the family have on the fire for dinner. Any mention of them should be prefixed by saying, "a blessing attend their departing and travelling! This day is Friday and they will not hear us." This prevents Fairy illwill coming upon the narrator for anything he may chance to say. $S H S 19$

1296. Uf di Få'senacht dærf mer net nēe oder mer nēt de hinkel di ærsch'lecher zu ạs si net lēğe kenne. (Be, $L b, L h, M t, N a, N u, S c, S n, Y$ )

If you sew on Shrove Tuesday you will sew up the hens' cloace and prevent them from laying eggs.

Fastnacht darf nicht geflickt werden, sonst "flickt man den hühnern die löcher zu" und sie legen nicht. $Z$ f $D$ M 1.200

1297. Wăs mer Freidåks å fangt bringt em gūt glik. (Mr) Anything begun on Friday brings good luck.

1298. Wămmer Mittwochs å fangt ebbes zu schạffe macht mer fîl mistē'ks. $(B e, C, D, L b, L h, M r, N a$, $N u, S c, S n)$

If you begin any work on Wednesday you will make many mistakes.

Mittwochs ist ein verworfener hexentag. Besucht ein kind Mittwochs zuerst die schule, so lernt es nichts. $G 3.613$

1299. Wạmer Mittwochs ebbes å fangt wært mer lạg net fær'tich. $\quad(M t, N a, S c)$

What you begin on Wednesday will take long to finish. 
- 1300. Der Kærfreidåk kērt mer all di schtuநe aus un ferbrennt seller drek, nō hot mer glik. (D, Lnc, Sc, $S n)$

Sweeping all the rooms on Good Friday and burning the sweepings brings good luck.

Kehrt man am Karfreitag seine stube nach einer entgegengesetzten richtung als gewöhnlich, z. b. statt vorwärts rückwärts, so ist man vor schwaben u. s. w. gesichert. $V A S 2.78$

1301. Zwische Grischdåk un Neijōr dærf mer net schpinne, un di schpūle misse lēr kassch'pelt sei fær Grisch'dåk, wannns sạch gūt wēre soll. $(B e, C, L h, L n c, M t$, $S c, S n)$

If homespun is to wear well there should be no spinning between Christmas and New Year and the spools should be empty before Christmas.

Vor den Zwölfen müssen die mädchen ihre spule leer haspeln und dürfen während der zeit nicht spinnen. Was auf der spule sitzen bleibt oder zugesponnen wird, hat doch keinen halt. $B S 33.126 ; M D V 252$

1302. Uf der Kærfreidåk dærf mer net mischte, schunscht mạcht mer de hexe di dir uf. $(B e, L h, Y)$

Stables must not be cleaned on Good Friday lest the witches enter.

Am Karfreitag hält man es gefährlich irgend etwas aus dem hause abzugeben, weil dadurch dem einfluss von hexen tür und tor geöffnet werde. V A S 1.322

1303. Uf Kærfireidåk soll mer ken flēsch esse ausgenumme fisch, schunscht hot mer ken glik mit seim ft. ( $L h$, Lnc, $\mathrm{Nu}, \mathrm{Sc}, \mathrm{Sn}$; Heidelberg)

Your cattle etc. will not thrive if you eat any meat other than fish on Good Friday.

1304. Mer lēkt hoi naus di Grischdåknacht sō âs der då druf kumme kạnn. Di Grischdåkmærğe fídert merm fł sell hoi, nō gēt em sell jōr ken fi dōd. (Be,C,Lh, Lnc, $S c, S n)$ 
None of your cattle will die throughout the year if on Christmas morning you feed them the hay which was put out of doors the night before to collect the Christmas night dews.

Viele füttern das vieh $\mathrm{zu}$ Weihnachten und Ostern mit heu, das über nacht der tau draussen genetzt hat. $M D V$ 213; Alem 20. 281

1305. Uf Quatem'ber dærf mer ken fit schlachte-aber fei ${ }^{-}$ mache. (D,Lb,Lh, Mr, Na,Sc; Stuttgart)

You must not butcher beef on an Ember day but you may cut it up.

1306. Uf der Quatem'ber dærf mer net wesche oder mer hot unglik. $\quad(B e, C, L b, L h, L n c, M r, N a, S c, S n, Y$; Freiburg)

Washing on an Ember day is unlucky.

1307. Uf Quạtem’ber dærf mer ken flēsch ei sąlze. ( $L b$, Sc; Freiburg)

Never cure meat on an Ember day.

1308. Uf Quatem'ber dærf mer net schląchte. (Mr, Sc; Freiburg)

Never slaughter any cattle on an Ember day.

1309. Wǣr uf Quătem'ber wescht wært grannk. (Be,C, Lnc, $M t, N a, S c$; Freiburg)

You will become sick if you do any washing on an Ember day.

1310. Wămmer uf Quạtem'ber wescht gēt em en schtik fi dỏd. $(N u)$

If you wash on an Ember day a head of cattle will die.

1311. Wạmmer uf der Quạtem'ber wescht gēt em ken fí̀ dōd bis der Quatem'ber wider kummt. (Be, Lnc; Freiburg)

If you do washing on an Ember day none of your cattle will die before the next Fmber day. 
1312. Uf Quatem'ber dærf mer net schlachte oders gēn em sell jōr sō fill schtik fł dōd às mer uf Quântem'ber gschlącht hot.

As many cattle will die during the year as are slaughtered on any Ember day.

1313. Mittwochs soll mer ken bedin'tes ei ${ }^{\sim} \operatorname{schte}^{-}$losse, oders bleibt net lang. (Be, Bu,C,D,Lb,Lh,Mr , $M t, N a, S c, S n, Y$ )

Any one who enters your service on a Wednesday will not stay long.

Keine magd wechselt Mittwochs den dienst. G 3.613

1314. De blume muss mer Neijōr winsche oder si blie net. $(B u, D, L b, L h, M r, N u, S c)$

Plants will not bloom unless you wish them a happy New Year.

Die blumen muss man auf Neujahr verstellen, sonst gehen sie kaput. Hlbg.

- 1315. Uf der Kærfrei'dåk dærf mer net nēe. (Af)

No sewing must be done on Good Friday.

Am Karfreitag darf man nichts nähen, sonst sticht man sich das ganze jahr in die finger. $B S 33.122$

1316. Uf di Grischdåknacht soll mer wasser nausschtelle un was druf gfrìt wært wōr. $(B e, C, D, L b, L h$, $\mathrm{Nu}, \mathrm{Sc}$ )

The designs formed on water which is set out on Christmas night to freeze are omens of the future.

In der Christnacht stellt man mit wasser gefüllte schüsseln aus. Läuft das wasser über nacht über, so tritt im kommenden jahr der Inn aus. $Z f D M 2.421$

1317. Di Grischdåknạcht schtellt mer wasser naus un wạs druf gfrírt gebt em mann sei hand'wærik. (Mr, Sc)

The forms in the ice which form on water which is set out on Christmas night indicate the occupation of your future husband. 
1318. Wammer sich Freidåks wescht soll mer di hend ąbdrikle ebs gsicht, nō grikt mer ken zå wē. $(L b, L h)$ You will not get toothache if when washing on Friday you dry your hands before drying the face.

Wer sich morgens gewaschen hat, muss mit dem abtrocknen am kleinen finger anfangen und bis zum daumen jeden finger einzeln abtrocknen, dann erst die arme und zuletzt das gesicht. Er wird dann nie zahnschmerz bekommen. B S 33. 138

1319. Mer dråkts un'gezifer all fært wạmmer uf der Eschemittwoch 's haus auskērt un seller drek nō me ạn'nere mannn uf sei la्nd dråkt. $\quad(L b, L h, N a, S c, S n$; Stuttgart)

You will rid your house of vermin if you sweep your house on Ash Wednesday and throw the sweepings on some one else's property.

-1320. Wạmmer leis im haus hot soll mers haus uf di Fåsenạcht auskēre un der kēr'drek uf me an'nere sei lạnd dråğe, nō gēn si wek. (Be, $L h, S c)$

To get rid of lice in the house sweep it on Shrove Tuesday and put the sweepings on some one else's property.

An Fastnacht muss die frau oder magd die stube auskehren und es nackt tun, und den kehricht vor die tür eines andern werfen, so bekommt dieses die flöhe. $W u$ 84

- 1321. Uf der Pạnnekuchedåk soll mer går nix schạffe. (C, $\mathrm{Lnc}, \mathrm{Mr}, \mathrm{Na}, \mathrm{Sc}$ )

No work whatever should be done on Pancake day.

An Fastnacht müssen pfannenkuchen gegessen werden.

Man darf nicht aufs feld gehen, nicht nähen oder flicken, nicht zum brunnen gehen, nicht stricken, haspeln, spinnen u. s. w. $W u 83$

- 1322. Di ēsch âs es uf di Fåsenacht gebt soll mer der Eschemittwoch uf fî un hinkel schtrēe di leis zu fercireite oder a ât'zuhạltē. $(A f)$

Shrove Tuesday ashes spread on cattle and poultry on Ash Wednesday will keep them clean of lice. 
Die asche von feuer, mit dem an Fastnacht oder Aschermittwoch gebacken wurde, in den hühnerstall gestreut, vertreibt das ungeziefer. $B M 24$

- 1323. Uf di Fåsena acht kērt mer di scheier aus. (Be, Lb, $L h, L n c, N a, N u, S c, S n$ )

Sweep the barn on Shrove Tuesday.

Jeder bauer mistet am fastnachtdienstag seinen hühnerstall, da dieser dann frei von hühnerläusen ist. Alem 20. 284

1324. 'S haus sott uf der Detlausdåk (der ēn'undreisichscht Mærz) ausgebutzt wærre uns sach nausgschittelt, nō gebts ken un'gezifer ins haus. (Be, $C, L b, L h, L n c, M r, N a, N u, S c, Y$; Nürdingen)

If you clean house on Detlaus' day and hang everything out, you will have no vermin in your house all year.

1325. Der tē as mer uf der Tschann Huss (der sext Tschulei') un der Mæri'eheim (der fufzēt Augu'scht) sammelt is noch'emōl sō schtærik âs d̄̄r a as mer an ēnichme ånnere dåk sạmmelt. (Lh, Sc,Y)

Tea gathered on John Huss and Virgin Mary is twice as strong as that gathered at any other time.

An den meisten orten in der Tirol werden kräuter am 14. August gepflückt; die weihe findet aber am feste Mariä Himmelfahrt statt. $Z$ f $D$ M 1.333

1326. Mittwoch is ken dåk. ( $A f)$

Wednesday is no day at all.

Mittwoch ist schon seinem namen nach kein voller tag. $W u 60$

- 1327. Der Kærfrei'dåk dærf mer net kēre oder mer grikt sell jōr ftl mike ins haus. $(N u)$

If you sweep on Good Friday you will have many flies all summer.

Man schafft überhaupt nichts. Hlbg.

1328. Der Himmelfærdåk sạmmelt mer nein særte graut oder alle blannz ass blit fer ftber. (Lnc, Y; Heidelberg) 
To cure fever gather nine species of herbs or any phanogamic plant flowering on Ascension day.

1329. Wămmer sei wesch di Neijōr draus henke losst muss mer alle dåk in sellem jōr wesche. $(D, Y)$

If your wash hangs out on New Year's, you will have to wash daily all year.

Wie das neue jahr anfängt, so geht das ganze jahr fort. $W u 66$

1330. Mittwochs dærf mer net wesche. (Lnc, Y)

Don't wash on Wednesday.

Am Mittwoch darf man den stall nicht reinigen. $W u 60$; ef. $W u 61$

- 1331. Wạmmer en scheier uf der Him'melfærdåk ufschlạkt, schlạkts giwit'ter nei . (Lnc, Nu; Heidelberg)

If a barn is raised on Ascension day, lightning will strike it.

1332. Kærfrei'dåks esse di A'mische ken brek'fescht. (Lnc) The Amish do without breakfeast on Good Friday. Da muss man nüchtern bleiben bis mittag. Hlbg.

1333. Wămmer di Grischdåk oder Neijōrnacht unner me båm en kuğel gìst sēnt mer der deibel. ( $L b)$

If you cast a bullet on Christmas or New Year's night, you will see the devil.

In der Weihnachtsnacht kann man den teufel beschwören .....Wu 262

1334. Der ērscht Freidåk im neie licht soll mer schla्chte. $(B u, S c)$

Butchering should be done on the first Friday in new moon.

1335. 'S flēsch nemmt mer uf der Detlausdåk aus em schmōk. $(M r, S c)$

Meats should be taken out of the smoke house on Detlaus day (March 31).

1336. Uf der Grí Dunnerschdåk muss mer ebbes grtnes esse, schunscht grikt mer der gretz in sellem jör. $(B e, L b, L h, M r, M t)$ 
Unless you eat some thing green on Maundy Thursday, you will get the itch.

In den zwölf nächten erbsen, linsen, bohnen nicht zu essen, sonst bekommt man die krätze. $G 3.56$

- 1337. Mer grikt ken leis wammer ebbes grìnes esst uf der Grí ${ }^{\sim}$ Dun'nerschdåk. $\quad(N u)$

You will not become lousy if you eat something green on Maundy Thursday.

1338. Uf der Grì Dun'nerschdåk soll mer ebbes grìnes esse, no grikt mer ken fíber. (Be,C,Lb,Lh,Mr, $M t, N a, S c, S n)$

Eat some green vegetables on Maundy Thursday to prevent fever.

Wer am Grünen Donnerstage nicht neunerlei kraut isst, der bekommt das fieber. $G R 503$

1339. Uf der A Abdañ dåk soll mer di dærne mēe un di fense butze. $\quad(C, D, L b, L h, M r, N a, N u, S c, S n, P)$ Briars and brambles should be cut and fences cleaned on Abdon's day.

Am tage Abdon (30. Juli) rotte man schilf aus teichen, dörner aus feldern, so wachsen sie nicht wieder. $G 3$. 140

1340. Wạmmer uf der Abdans dåk mit me săk'messer dærich di rinn fume båm schneit, gēt der båm dōtẩer der dåk is ferschōte im kălen'ner. ( $A f)$

Draw the blade of a pocketknife through the bark of a tree and the tree will die-but the date given in the almanac is not the correct one.

Am Beatrixtage (29. Juli), auch "Abdorn" genannt, wohl deshalb, weil nach dem alten kalender der 30 . Juli S. Abdorn und Sennen geweiht war, muss man jäten, unkraut und ungeziefer vertilgen. Bäume, sträucher und alle pflanzen an diesem tage geschnitten, vertrocknen. B $S 33.123$

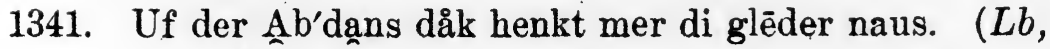
Lnc, $M r$ ) 
Clothing should be hung out on Abdon's day.

Karfreitags die kleider an die sonne gehängt, kommt weder motte noch schabe hinein. $G 3.355$

1342. Uf der $A b^{\prime}$ dans dåk kërt mers haus hinnerschich aus, sell ferdreibts ungeziffer. ( $B e, B u, C, L h, L n c$, $M t, S c)$

Sweep your house backwards on Abdon's day (July 29 or $30)$ to exterminate vermin.

Am S. Abdonstage muss man ungeziefer vertilgen. $B \boldsymbol{S}$ 33.123

1343. Di Grischdåknacht is es wasser in de brunne drei minu'te lang wei . (Lnc)

On Christmas night water in wells is changed into wine for three minutes.

Christnachts, zwischen elf und zwölf, ist das wasser wein. G 3.54

1344. Is es wasser nau wei -

Såkt der deiநl, dū bischt mei . (Lnc)

Has the water now turned to wine?

Saith the devil: thou art mine.

1345. Mit Mærze schnē wạsser kạmmer di bescht sēf koche. (Nu; Kaiserslautern)

March snowwater makes the best soap.

1346. Im Mærz gebts es bescht mēl. ( $\mathrm{Na} ;$ Kaiserslautern), The best flour is made in March.

1347. Mittwochs un Freidåks dærf mer ken schtell ausmischte. (D)

Stables must not be cleaned on Wednesday or Friday.

Mittwochs und Freitags darf man keinen stall ausmisten. Alem 19. 164

1348. Mittwochs dærf mer di schtell net ausmischte. (Be, $D, L b, L h, N a, S c, Y)$

The manure must not be taken out of stables on Wednesday.

Mittwochs darf man keinen stall ausmisten. Alem 19.164 
1349. Mer hot ken glik mit em fit wammer di schtell zwische Grischdåk un Neijōr ausmischt. (Be,Lb,Lh,Lnc, $M r, S c, Y$ )

Your eattle will not thrive if you clean the stables between Christmas and New Year.

Mit der Sperrnacht darf misten nicht besorgt werden. $M$ D $V 252$

1350. Zwische Grischdåk un Neijör soll mer ken schtell butze oder mischte schunscht hot mer drubel mit de hexe. ( $B e, L h, S c, S n)$

Stables should not be cleaned or dunged between Christmas and New Year, or you will have trouble with witches.

In den Zwölften darf kein mist ausgefahren werden, sonst kommt ungeziefer, krankheit, tod und allerlei unheil in das haus. $W u 64$

1351. Zwische Grischdåk un Neijōr dærf mer net dresche und net mischte. $(B e, L b)$

Between Christmas and New Year you must not thresh or dung the stables.

Man soll in den Zwölfen nicht dreschen, das getreide verdürbe, so weit der schall gehört wird. $G 3.418$

1352. Zwi'schich Grischdåk un Neijōr soll mer sich net wesche un net wesche un à net rumschtripe oder mær hot ken glik. ( $B e, L b, L h, M r, S c ; H e i d e l b e r g)$ You ought not to take a bath or wash or change clothing between Christmas and New Year, for you will have no luck.

1353. Wạmmer zwische Grischdåk un Neijōr wescht wært mer grank. (Lb)

If you wash between Christmas and New Year you will become sick.

In den "Zwölfen" darf man nicht waschen lassen, sonst wird man im neuen jahr krank. $A S 8$ 
1354. Zwische Grischdåk un Neijōr soll mer sich net wesche oder rumschtripe, oder mer hot ken glik. ( $B e, L b$, $L h, M r, S c)$

If you take a bath or change clothing between Christmas and New Year you will have bad luck.

1355. Zwischich Grischdåk un Neijōr dærf mer sich net rumschtripe oder mer wært foll gschwǣe. (Be, $B u, C, L b, L h, M r, M t, N a, S c, S n)$

If you change underwear between Christmas and New Year you will be full of boils.

Man darf am Neujahr kein frisches hemd anziehen und keine äpfel essen, sonst bekommt man schwären. $W u 65$

1356. Uf di Neijōr dærf mer ken sauter hemm å dū oder mer grikt gschw̄̄re. ( $B e, D, L b, L h, M r, N a, N u$, $S c, S n ;$ Kaiserslautern)

Never put on a clean shirt on New Year's for fear of having boils.

1357. Uf di Neijōr dærf mer ken ebbel oder niss esse oder mer wært foll gschwæ̈re. $(C)$

Eating apples or nuts on New Year's causes boils.

Man darf am Neujahr keine äpfel essen, sonst bekommt man schwären. $W u 65$

1358. Schneid di neğel alle Freidåk anb, no grikscht ken koppwē. $(L b)$

Cut your nails every Friday to prevent headache.

1359. In de Hunnsdåk dærf mer net schwimme gẽ $\tilde{e}^{\sim}$ oder mer grikt gschwæ̈re. (Af; Heidelberg)

You will have boils if you go swimming during the Dog days.

Bathing in the Dog days is more dangerous than at other times. $V S L 2.615$

1360. Freidåks soll mer nix neies å fạnge, mer hot ken glik mit. (Af)

Work begun on Friday will never turn out well.

Am Dienstag und Freitag soll man keine neue arbeit an. fangen, denn man hat miserfolg dabei. $W u 70$ 
It is on Fridays that fairies have the most power to work evil; therefore Friday is an unlucky day to begin work. or to go on a journey or to have a wedding. Ir 2. 212

1361. Wămmer Sạmschdåks å fangt ebbes zu schąffe wært mer lang net fær'tich. (Af; Heidelberg)

It will take a long time to complete anything that is begun on Saturday.

Never begin to make a dress on Saturday or the wearer will die within the year. $I r 2.115$

1362. Uf di Grischdåk soll mer brōt nauslēğe so a s es gfrirt. Wạmmer sell esst grikt mer ken fíber. ( $B e$, $L h, S c, S n)$

Eat bread frozen on Christmas day to prevent fever.

Sät man in der Christnacht brosamen, so gehen sie auf. $Z$ f $D M 2.422$; cf. also $A S 1.382$

1363. Di Grischtblum gēt di Grischdåknancht zwische elf un zwelfe uf, wănn di ki schwetze, 's maxcht nix aus wì kalt ass es is. (Af)

The Christmas plant (Helleborus viridis) will bloom on Christmas night between eleven and twelve, when cattle talk, regardless of the weather.

In der mitternachtstunde der Christnacht spriesst der hopfen, auch bei schnee, fingerlang empor. $W u 69$; ef. $Z 882$

Thorntrees blossom at twelve o'clock on the night of the Nativity to commemorate the Savior's birth. $D E C 52$

1364. Freidåks is en ungliksdåk fer ē'nich ebbes å fange. $(B u, C, L b, L n c, M t, N a, N u, S n, Y)$

Never begin anything on Friday, it is an unlucky day.

In katholischen ländern ist Freitag der unglücklichste tag. $W u 61$

Alles ist nichts, was man Freitags anfängt. Hlbg.

Never undertake any business of importance on Wednesdays or Fridays. W Ir 63

1365. Mittwochs un Freidåks soll mer net trąநle gẽ . (Nu) You should not begin a journey on Wednesday or Friday. 
Am Freitag darf man nicht verreisen. $W u 61$

Never begin a journey on Friday. W Ir 63

1366. Mittwoch is en ungliks dåk. ( $B e, B u, C, D, L b, L h$, Lnc, Mt, Na, Nu, Sc, Sn)

Wednesday is an unlucky day.

Mittwoch und Freitag gelten in Süddeutschland als unglückstage. $M D V 175$

Those that begin journeys on Wednesday shall run through much danger. D Eng 241

1367. Mittwoch is der bescht dåk fun all. (Lnc, Sc, Sn)

Wednesday is the best day of all.

In Devonshire Tuesdays and Wednesdays are regarded as lucky days. D Eng 240

1368. Uf Grischdåk soll mer ken flēsch esse eksept' fun fe'derft. Wămmer anner flēsch esst hot mer ken glik mit em ft. $(L h, M r)$

You will have no luck with your cattle if on Christmas you eat any meat other than poultry.

Isst man in den zwölften fleisch, so fällt das beste vieh im stall. $G 3.814$

1369. Wạmmer Mūndåks ebbes fær'tich mạcht kạmmer selli woch fill schaffe. ( $A f$; Heidelberg)

If you complete a piece of work on Monday you will accomplish much that week.

1370. Reğewassser fum Him'melfærdåk is gūt fer wēe åğe. (Be, C, D, Lh, Mt, Na, Sc, Sn, Y; Heidelberg)

Water from Ascension day rain will cure sore eyes.

For weakness of the eyes, use rain water collected in a clean open vessel in the month of June. It may then be bottled. $V S L 2.495$

For weak eyes, use rain water that falls on Holy Thursday. $V S L 2.495$

1371. Wǣr di Grischdåknącht gebōre is sēnt gschpuker un kannns ff hēre schwetze. ( $B e, B u, C, D, L b, L h, L n c$, $N u, S c, S n)$

Var. kann fer ë'nich ebbes brauche. 
A person born on Christmas night can hear cattle talk and ean see ghosts.

Wer am Johannistage oder an einem Sonn- oder Festtage geboren ist, kann geister und zukünftiges sehen. $B S$ 33.123

A child born on Christmas day or on Good Friday will be able to see spirits. $V S L$ 2.1.218

1372. Der sibezēt Tschūn is en unglicksdåk. (Lnc) Jume 17 is unlucky. 


\section{HORSESHOE}

1373. Wạmmern hūfeise findt hot mer glik. (Af)

Finding a horse shoe is lucky. $Z 237$

To find and pick up an old horse shoe or a rusty nail or a crooked pin brings good luck. $V S L 2.33$

1374. En gfunne hüfeise mit all de neğel drin is güt fer brauche mit. (Lnc, Sc, Y)

Powwow with a horse shoe which has the regulation number of nails and which was cast by a horse.

1375. Mær dærf net ąme hüfeise ferbei'fåre oder mær hot ken glik. (Bu, Mt; Heidelberg)

It is not lucky to drive past a horse shoe. 


\section{HUNTING AND FISHING}

1376. Wạnn en weibsmensch me jåkhund di nås mit trm schærz reibt gēt er der ganz dåk 's hin'nerschtfe'derscht uf der schpūr. (Lh; Heidelberg)

If a woman rubs her apron over the nose of a hunting dog he will be worthless all day.

1377. Der Himmelfærdåk is der fisch dåk. ( $B e, B u, C, L b$, $L h, M t, N a, S c, S n$; Kaiserslautern)

Ascension day is the time when you should go fishing for the first time in spring.

1378. Wămmer fische gēt uns låft en weibsmensch i'ber der wēk kạmmer seller dåk ken fisch fange.

If a woman crosses your path when going fishing, you won't eatch any fish.

Wenn einem jäger des morgens ein altes weib begegnet, so soll er nur wieder heimgehen. $Z$ f $D M 4.48$

1379. Mer muss ufs bēt schpaue eb mer nei $\sim$ schmeist, nō beise di fisch besser. $(A f)$

Always spit on bait before casting.

Man muss speien auf den köder, den man an die angel befestigt hat, weil dann der fisch besser beisst und fester hängt. $\quad L 332$

1380. Wann iøerm fische di schlangehiter sich uf di gært oder lein hoke kạmmer ken fisch fange. $(B e, L h$; Heidelberg)

You won't catch any fish if a dragon fly alights on your rod or line.

When boys go fishing, the dragon flies point out the places where the fish are by setting on the banks or flags, in the proper direction. D Eng 134

1381. Wạmmer flucht iberm fische fangt mer nix. ( $B e, L h$, $\mathrm{Na}$ ) 
If you swear while fishing you will not catch any fish.

If you swear, you'll catch no fish. $V S^{\prime} L 2.138$

1382. Uf Kærfreidåk soll mer 's ērscht mol im jōr fische ge $\overline{\mathrm{e}}^{\sim}$, nō beise di fisch 's gannz jōr. $(B e, C, D, L b$, $L h, M r, Y$ )

You will have good look in fishing all year if you fish the first time in the year on Good Friday.

Am Grünen Donnerstag und Karfreitag geht man fischen. $\mathrm{Fr}$ 


\section{FOLK MEDICINE AND MEDICAL SUPERSTITIONS}

1383. Wạmmer di heibs hot soll mer sich anme seinescht reibe. $(C, Y)$

To stop hives, rub yourself on the pigs' litter.

1384. En weisser wol'licher bendel um en gnechel gebunne kjürt grundgretz. $(\mathrm{Nu})$

A white woolen cord tied about the ankle cures ground itch.

1385. Grumbìre sin gūt fer peils. (Be, $D, L b, L b)$

Potatoes are good for piles.

1386. Wạnn ēns di wi'belsucht hot schtekt mers in en mël'sąk, oder reibts mit kærn'mēl. (Af)

To cure nettleraoh, crawl into a flourbag, or rub with rye flour.

Wer die nesselsucht hat, muss rückwärts in einen frisch ausgeschütteten mehlsack hineinkriechen, dann vergeht sie an demselben tag. $B S 33.133$

1387. Wasser un'ichs bett gschtellt soll gūt sei a as en grankes sich net ufleit. ( $B e, C, D, L b, L h, L n c, N a$, $S n, Y)$

Water placed under the sick person's bed is said to prevent where the fish are by sitting on the banks or flags, in the bed sores.

Ein gefäss mit kaltem wasser täglich frisch unter das bett eines schwerkranken gesetzt, schützt vor dem wundliegen. B S 33.142

1388. Schtell en hạfe wū noch går nix drin wår un'ichs bett, so a a en grankes sich net ufleit. $(N a)$

To prevent bedsores place a hitherto unused crock under the bed.

1389. Lëk di ax u'nichs bett sō âs en grankes sich net ufleit. $(B e, L n c)$

Lay the axe under the bed to prevent bedsores. 
1390. Mer soll en ēmer wąsser un'ichs bett schtelle wann ēns nachts schwitzt, nō fergēts. $(B e, C, D, L b, L h$, Lnc, $Y$ )

A pail of water put under the bed will stop nightsweat. For cramp keep a pan of clean water under the bed. $V S$ $L 2.592$

1391. Der schnuppe lōs zu wærre, rtch dreimol in der schū. $(N u, Y)$

To cure coryza, sniff three times into your shoe.

Ein weib, die den schnupfen hat, soll in des mannes schuhe riechen. $G 3.361$

1392. Fer mut'terwē får mit em finger zwische de zēe dærich un rìch nō drå̃ $(L b, Y)$

For hysteria, pass your finger between your toes and smell at it.

1393. Wạmmer sich en rūk'schtē un'ichs kop'pekissi lēkt kămmer gūt schlōfe. $(B e, D . L b, L n c, M r, N a$, $S n, Y$ )

If you put a small roundish stone, found lying on fenceposts in the country districts, under your pillow, it will induce sleep.

[This is probably an echo of the Donarkeil.]

Wer nicht wohl schlafen kann, kind oder alt, dem soll man einen ruhewisch unter das kopfkissen legen: das ist stroh, was wagfrauen unter den rücken legen; man muss ihn aber diesen leuten stillschweigend wegnehmen. $G 3$. 296

1394. Wạmmern schliber in der hand hot soll mer håsefett obe uf di hand schmire, sell zîkt en raus. $(C, M t$, $S n)$

You can extract a splinter lodged in the hand by greasing the back of the hand with rabbit grease.

Hasenfett soll fremde körper aus den wunden ziehen. $L V$ 87 
The sloughs of snakes are also used for extracting thorns. Thus, if the thorn has fastened in the palm, the slough must be applied to the back of the hand, for its virtue is repellent, not attractive. $B \quad F 156$

1395. Me kind as wærm hot lēkt mer fei gemacht glås uf der natbel. ( $\mathrm{Be}, \mathrm{Na}, \mathrm{Sc})$

Put pulverized glass on the navel of the child afflicted with vermes.

Die probe, ob ein kind würmer hat, wird in der Pfalz so angestellt, dass man eine mit blei und mit "spitzglas" und zuweilen mit "venerischem" glas gefüllte nussschale auf den nabel bindet. $L V 132$

1396. 'S wasser fun nein gekochte oier dreibt me mëdel ir kind a ab. $(B u)$

Drinking the water in which nine eggs were boiled will cause abortion.

Die geburt zu befördern, lässt man zwei eier wie gewöhnlich sieden, und gibt der frau ein paar löffel von dem wasser, darin die eier gekocht sind, ein. $L V 166$

1397. Mer muss der recht schtrump 's ērscht å dū koppwē oder zå wē zu ferhite. (Lb; Kaiserslautern)

To prevent headache or toothache put on your right stocking first.

Wer am abend, wenn er ins bett geht, zuerst den linken schuh und strumpf abzieht und am andern morgen den strumpf, der vorher am linken bein gewesen, dem rechten anzieht, der bleibt von zahnweh verschont. $H Z 48$

1398. Wąmmer sich ferschtrē'nt hot soll mern gidæ'rrti olehaut drum binne. $(\mathrm{C}, \mathrm{Na}, \mathrm{Sc})$

A dried eelskin around the part cures a sprain.

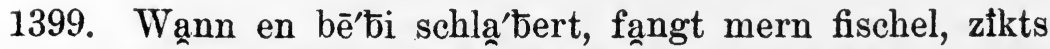
em kind dærichs maul, â̄er mer muss 's fischel wider zurik' ins wạsser dū $\sim$ ebs dōd gēt. (Be,Lb,Lh,Lnc, $M r, M t, N a, N u, S n, Y$ )

When a baby slobbers pass a small fish through its mouth, returning the fish alive into water. 
For whooping cough, put a live trout into the child's - mouth, fasting. Then put it back alive into the stream. W Ir 13

1400. Fer wildfeier, schmir gens'drek, gschåbter holler un schōf' inschlich druf. $(L b, Y)$

A salve made of sheep tallow, scrapings from elder and goose dung will cure erysipelas.

1401. Wăsser fum ērschte schnē im winter is güt fer wēe åğe. (Be, Bu, Lb, Mt,Sc,Sn, $Y$; Heidelberg)

Water from the first snow in winter is good for sore eyes.

1402. Wạmmer zwiђle im sạk nōdråkt, grikt mer ken pærble. $(L b, S n, Y)$

To prevent smallpox carry onions in your pocket.

1403. Mer grikt ken pær'ble wạmmer dei'bels drek im sạk nōdråkt. (Bu, Lb, Mt, Sn, $Y$; Lenzkirche)

Assafotida carried in the pocket will prevent smallpox.

1404. Tē muss mer im schạtte dærre. $(\mathrm{Na})$

Herbs for medicinal purposes must not be dried in the sun.

....in der sonne. Hlbg.

1405. Drau'toschtokblūt is gūt fern mostą'sch waxxe maxche. (Lnc, Nu; Kaiserslautern)

Sap of grapevines will make a moustache grow.

1406. Fer sōtbrenne hēb di hend un'ich di ̄̄erm bis si wårm sin un rìch nō drå̃. ( $L b, Y$; Neustadt)

To cure waterbrash, warm your hands under the arm pits and then smell them.

1407. Waגmmers bēsding' an finger hot dærf mer num'me jō ken zwible esse, schunscht hēlts sei lēbe net. ( $L b ; H e i d e l b e r g)$

When you have a felon, never eat onions, or it will never heal. 
1408. Wạnn ēns di ko'lik hot, schåbt mer di fìr disch'eke ab un gebts em ei ${ }^{\sim} . \quad(B e ;$ Kaiserslautern $)$

For colic, scrape the corners of the table and take the scrapings internally.

1409. Gēsbruns is guit fer nt're granket. ( $\mathrm{Na}$; Heidelberg)

Goat urine is good for kidney disease.

1410. Mer soll en bendel um der finger binne wammer fergesslich is. $(\mathrm{Na})$

Tie a string about the finger if you are forgetful.

Man bindet einen knopf in das sacktuch. Hlbg.

1411. Wạmers gift hot brunst mer druf. (Bu, Mt; Freiburg)

Urinate on ivy poison.

1412. Fer rēd'le oder schán'lach rausbringe, soll mer tē fun schōf'gnodle drinke. (Be, Bu,D,Lb,Lh,Lnc, Mr, $M t, S c, S n, Y$; Freiburg)

Drink a decoction of water and sheep dung to produce rash in measles or scarlet fever.

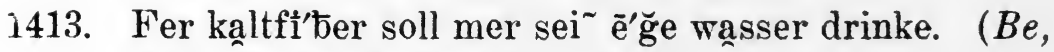
$L b ;$ Kaiserslautern)

Drink of your own urine to cure ague.

1414. Schlank kạ'lik mit Mærze schnē. 'S heidel a sis sich ufs wasser schtellt macht en gït blaschter. (Be, Lnc, Sc, Sn, Y; Freiburg)

Slake lime with March snow. The membrane which forms on the water makes a good ointment.

1415. Mer schåbt di fingerneğel åb un duts in brandewei ${ }^{\sim}$. Wạnn en sauf'lōdl sell drinkt kạmmerm's saufe a a b'gewēne.

Scrapings of fingernails put into whiskey and given a drunkard to drink will cure him of his inebriety.

Wenn man einem wasser zu trinken gibt, in das "nagelschabete" geworfen wurde, so bekommt der betreffende die auszehrung. $V A S 1.488$ 
1416. Wạmmern wē maul hot soll mer ins feier schpaue. $(B e, C, L b, S c)$

Spitting into fire cures a sore mouth.

1417. Wammer ins feier schpaut, grikt mern wē maul. $(L h, N a, S n)$

Spitting into fire (i. e. a stove) causes a sore mouth.

Ins feuer darf man nicht spucken, sonst bekommt man ein grindmaul oder blasen auf die zunge. $W u 14$

1418. Rōtrîbe esse mạcht rōt blūt. $(B u, M t)$

For anæmia or impurity of the blood, eat beets.

Wenn man rote rüben isst, bekommt man rote backen. $W u 67$

1419. Wạmmer năğelfluss oder bēsding' hot, soll mer der wē finger re kạtz ins ōr schteke. $(B e, L h)$

To cure whitlow or felon put the sore finger into a cat's ear.

Wurm im finger (panoritium) heilt man, indem man den finger eine zeitlang einer katze ins ohr steckt. $W u 347$

1420. Wạnn em di nås blūt, soll mer drei droppe blūt uf en hēssi feierschaufel dropse losse, un si nō runner dū̃. Des dut mer drei mōl. (Bu; Heidelberg)

To stop nose bleed, let three drops of blood fall on a heated fire shovel and then remove them. This should be done three times.

1421. Dråk peilswærzel nō fer peils. ( $B e, L b, L n c, M t$, $\mathrm{Na}, \mathrm{Sc}, \mathrm{Sn}, \mathrm{Y}$ )

Carry horse balsam (Collinsonia canadensis) as a cure for hemorrhoids.

1422. Wạmmer kærnblitt esst grikt mer ken fíber. $(B e)$

Eating rye blossoms prevents fever.

Um sich das ganze jahr gegen fieber und allerhand krankheiten zu schützen, muss man von dem ersten roggen, welchen man im frühjahr blühen sieht, drei blühende ähren stillschweigend durch den mund ziehen und die dabei abgestreiften blüten verschlucken. $B S$ 33. 131 
1423. Wạmmer drek in en åk grikt, soll mers annner åk reibe. $(L b)$

Remove a foreign substance from the eye by rubbing the other eye.

Fällt einem etwas ins auge, so reibt man das andere ange. $W u 350$

1424. Wạmmern rassselschlang dōdmạche kann ạs si sich net beisst, brōt mer si wì en ōl un esst si. Sell kjūrt di aus'zēring. $(D, L n c, S n)$

A rattlesnake, killed without biting itself, should be fried like an eel, and eaten, to cure tuberculosis.

Ein in schlangenblut getauchter faden um den hals getragen heilt blutspucken. $W u 116$

1425. Wannd der schlixer hoscht, setz dich uf en schtūl, schtell en glås wasser nē'bich dich, dũ ${ }^{\sim}$ we'nich wasser in di ore mit de glēne finger un hallt si drin bis du 's wassser all gedrunke hoscht. (C; Kaiserslautern)

For hiceoughs: sit down, with a glass of water by your side, let some one put a little water into each ear with the little finger of each hand and keep the fingers there until you have drunk the water.

1426. Wạmmer di drei ērschte feilcher esst as mer frijōrs finnt grikt mer sell jōr ken fí’

To prevent fever for the entire year, eat the first three violets found in spring.

Vor kaltem fieber schützt man sich, wenn man das erste erblickte veilchen kaut. $W u 353$

1427. Wannd schlixre musscht, ess we'nich zuker. ( $A f$; Kaiserslautern)

For hiccoughs eat a little sugar.

1428. Ebber a as mit grạmpp behânft' is soll mærğets ufschtē $\tilde{}$, nix schwetze un naus $\mathrm{ge}^{-\tilde{}}$ un en alter- . mąnnnschtok blannze. $(B e, Y)$ 
If a person is subject to cramps he should immediately on getting up and without speaking a word plant some southern wood (Artemisia abrotanum).

Ein mädchen von einem bösen geiste genommen, der mit ihr zur hölle fahren wollte, raffte aber noch mit der hand allermannshermkraut zusammen, das am boden stand, da musste der geist sie loslassen. $Z$ f $D M 1.201$

1429. Mer schtreicht en licht i'toern dōdes un reibts nō ạn de grēn'åğe, sell ferdreibt si. $(B e, L h)$

Corns will disappear if rubbed with a candle which was rubbed on a corpse.

1430. 'S fett as mer grikt fum bă è'nich ebbes. ( $B e, L b, L n c, N a, S c, Y)$

The fat in which a balsam apple (Echinocystis lobata) is fried has healing properties.

1431. Loss en bălsemábbel in en bottl waxe, un wănn er ausgewaxe is dut mer drinke druf. Wammer sell uf é'nich ebbes schitt oder reibt, hēlts 's gschwind. $(L b, L h, L n c, M r, M t, S c, Y)$

Grow a wild balsam apple (Echinocystis lobata) in a bottle; when ripe, fill the bottle with whisky. This will heal any wound on which it is poured or rubbed.

1432. Wămmern nìs schpell hot soll mer der tip fun der nås å̃uke mit de zwē åğe. (Lnc, Sn; Kaiserslautern)

Look at the tip of your nose with both eyes to stop sneezing.

1433. Der dạmpp fun wol'legraut tē is gūt fer zwang. (Lnc, Y)

Tea made of mullein (Verbascum thapsus) cures tenesmus. ....Wollblumentee. $\mathrm{Kl}$

1434. Der dạmpp fun schwærzer tē is güt fer zwang. ( $L b$, Lh, Lnc, $Y$; Kaiserslautern)

Steam from black tea stops tenesmus. 
1435. Fer zwąng: Gråb pōkwærzle, koch si un hok dich i'ber der dąmpp. (Be, $S c, Y)$

To stop tenesmus: take of the roots of pokeweed (Phyto. lacca decandra), boil them and sit over the steam coming from the vessel.

1436. Dråk geilskeschte nō fer peils. ( $B e, L b, L n c, N a$, $Y$; Heidelberg)

Carry horse chestnuts (Aesculus hippocastanum) for hemorrhoids.

1437. Fer ketǣr', reib geils'keschte fei un schnupp si. (Be, Lnc, Na, Sn, Y; Heidelberg)

To cure eatarrh, grate horse chestnuts (Aesculus hippocastanum) and snuff them.

1438. Fer fạlletgrankket schluk en rạsselschlanngehærz. (D, $Y$ )

To cure epilepsy, swallow the heart of a rattlesnake.

1439. Ebbes ferschtrēn'tes oder ferrenk'tes muss mer immer un'nerschich reibe. (Be, Bu,Lnc, $M t, S c, S n$, $Y$; Heidelberg)

Sprains or dislocations should always be rubbed downward.

1440. Dær'bendel um di gnechel binne kjūrt kąlte fis. $(D, Y)$

Cure cold feet by tying tar rope about the ankles.

1441. Fær muttergichtrē schpau uf en schtē- un gråb en un'ich der dạchdråf. $(D, L n c, Y)$

To stop puerperal convulsions, spit on a stone and bury it under the eaves.

1442. Nemm en kōl ins maul wannnd sōt brennes hoscht. $(L n c, N u)$

Put coal into your mouth to stop water brash (Pyrosis).

1443. Færs bēsding' an finger petz der finger hinnich di dir. $(B u)$

To cure a felon, place the finger between the door and its jamb and have some one close the door. 
1444. Wạnnd der um'låf hoscht, lēk der finger in en wặge glēs un såk: ich begråb dich. (Na; Kaiserslautern)

To cure run-a-round (paronychia), put the finger in a rut in the street, saying: I bury thee.

1445. 'S wassser fun draube ranke as mer im Mærz schneit is gūt fer wēe åge. (Bu; Freiburg)

The sap of grapevines pruned in March is good for sore eyes.

1446. Wēe åge wescht mer mit drauђewąsser. $\mathrm{Na}$; Freiburg)

Bathe sore eyes with the sap of grapevines.

1447. Schı́ en bruch zurik' mit me biğeleise. (Lb, Lnc)

Use a sadiron in reducing a hernia.

1448. Mer schibt en bruch zurik' mit me gschmid'ne nạggel, schlakkt en nō in holz un halt en im drukne. (Be, $L b, L n c, N u, S n$; Heidelberg)

In reducing a hernia use a forged nail, which should then be driven into wood and kept in a dry place.

1449. Wạmer seitschteche hot, hēbt mern $\operatorname{schtēe~}^{-}$uf, schpaut hĩ wū er gele'ğge hot, lēkt der $\operatorname{schtēe~}^{\sim}$ nō wider hî un såkt: nemm mei schteches ewek'. Mer duts drei mōl un halt jē'dermol der ochtem. (Af; Heidelberg)

To stop stitches in the side (pleurodynia) pick up a stone, spit on the spot and replace the stone, saying: take away my stitching pain, at the same time holding the breath. This should be done three times.

1450. Wạn en kind a b'nemmes hot, schtēl en leffel un fí'ders kind mit sellem leffel. $(C, Y)$

Cure marasmus in a child by feeding it with a stolen spoon.

1451. En bei'del grikt fume schnitter un um der hạls kenkt un dærte gelosst bis er fun selbert abfallt is en gūti kjür fer halswē. (Bu, Mt; Kaiserslautern) 
To cure sore throat, get from a gelder the scrotum of an animal eastrated by him, hang it about the neck and leave it there till it falls off.

1452. Fer năğelfluss: schtek der finger in en un'gebōrt loch un såk: Ich schtek dich in en un'gebört loch. Năğel, mạch dich wider druf. (Be,C,Lb,Lh, Sn, $Y$; Heidelberg)

For whitlow, put the sore finger in a natural hole, saying: Nail, I put thee in an unbored hole. Now grow in place again.

1453. Wămmern hūf'eise finnt mit all de neğel drin mạcht mern schtang defun', un mit sellre schtang hēss gemacht brennt mer der biss fume wi'diche hund aus, nō wært mer net w'dich. (Be, Lh, Mt, Sc)

To prevent rabies as a result of the bite of a mad dog, cauterize the wound with the heated bar of iron made from a found horseshoe containing the regulation number of nails.

In Westhausen ist ein eiserner schlüssel, von welchem sie sagen....er habe die kraft, dass wann ein mensch oder vieh von einem wütigen hunde oder rasenden tier gebissen oder sonsten verletzt, damit gebrennet werde, so heile es den schaden wunderlich. $A S 1.106$

1454. En diker hạls schtreicht mer mit der butzing, nō fergèt' er. (Be,Lb,Lh,Lnc, Na,Sc,Sn; Freiburg)

Rub a goiter with an afterbirth.

1455. En å gewaxe kind schtekt mer dærich en ku'met. (Af; Freiburg)

Pass a livergrown child through a horse collar.

1456. Wạn ebber der schlixer hot soll mern ferschreke. (Af)

Frighten the person suffering with hiccough.

Wenn einer den schnaggel hat, soll man ihn erschrecken. $Z 221$ 
1457. Wămmers låb fun dæ'richwax e'berschich åt'schtribt un macht en tē defun', mạcht der tē em breche; un'nerschich, laxiı̀t' er. $(C, D, L n c, M r, N u, S c, S n$, $Y)$

The leaves of boneset (Eupatorium perfoliatum) stripped upwards and made into a tea, will act as an emetic; stripped downwards, a purgative.

Schabt man ein stück holunderwurzel nach oben, so dient der saft zum brechen, schabt man es nach unten, so dient er zum abführen. $W u 322$

1458. En gạnz schwærz hinkel dōd gemącht une blūt ferschitt, mitzanmmte fe'dre gebrit un gekocht, un en supp defun gekocht un gesse is en schüri kjür fern feschter leib. ( $L b, L n c)$

Kill a chicken without shedding blood, boil it, feathers and all, and make soup of it, which, when eaten, will cure constipation.

Eine kindbetterin darf nur suppe von einem ganz schwarzen huhn bekommen. $Z f D M 4.1$

1459. Mer grikt ken fïber wạmmer schlōsse esst. $(B e, L b$, $L h, M r, S n$ )

Eating hailstones prevents fever.

....Man soll keine essen. Hlbg.

1460. Mer wært sell jōr net grănk wănmer pår schlōsse esst fum ērschte schlōssewetter im jör. (Be, Lnc, $M r, S n$ )

Eating a few hailstones from the first hailstorm of the year prevents sickness for the rest of the year.

1461. Gift reibt mer mit glåsgraut. (Af; Nürtingen)

Cure ivy poison by rubbing pale touch-me-not (Impatiens pallida) on it.

- 1462. Uf Kærfreidåk esst mer drei hært gekochte oier, nō grikt mer ken fíber. $(B e, L b, L h, S c)$

Eat three hard boiled eggs on Good Friday to prevent an attack of fever.

Karfreitagseier sind für die mannsleute, damit sie kein fieber bekommen im lauf des jahres. Alem 25.109 
1463. En gewex' mącht mer nasss mit schpautz ferm esse. (Be, Lnc, $Y$; Heidelberg)

Moisten a tumor with fasting spittle.

1464. Ni'derer wilder wær'mūt in stsse mi'lich gekocht un druf gebunne so oft as es kalt wært, is güt fer peschtblōder. ( $B e, L b, L h, M r, N u$; Heidelberg)

To cure a carbuncle, boil bitterweed (Ambrosia artemisiaefolia) in sweet milk, and apply it as a poultice, replacing it as soon as cool.

1465. Brōt uf der Kærfreidåk gebạke mạcht en gūt pōl'tis fern wund hēle. (Be,C,Lh, Sn; Freiburg)

A healing poultice is made of bread baked on Good Friday.

1466. Wammer sichs uf der kopp reğere losst in de hunnsdåk grikt mer fil koppwē oder di hōr gēn em aus. (Be, C, Lh, Lnc, Sn, Y; Heidelberg)

Rain falling on the head during dogdays will cause headache or baldness.

1467. Wạmmer ēns mit hēss fett schmîrt leit sichs net uf. (Be, Bu, Lh, Lnc, Mt, Na, Sn; Heidelberg)

To prevent bedsores grease the sick person with hot lard.

1468. Wạmmers gsicht mit molke wescht grikt mern schēni weissi haut. (Bu, C, Lb, Mr, Na,Sc, Sn, Y; Heidelberg)

Washing the face with whey produces a fine complexion.

1469. Wammern schēni weissi haut hậe will muss mer sich mit em lumbe ąbbutze wũ mer di milichkannne mit auswescht. (Be, D, Lh, Lnc, Mt, Sn, Y)

Washing the face with the cloth used in washing milkcans produces a beautiful white complexion. Man wäscht das gesicht mit mileh. Hlbg.

1470. Wąnn en kind a abnemmes hot schmirt merm ótbeds der bukel mit hu'nich un mærğets schåbt mern ăb mit 'm rik fume ballbtr'messer. So mącht mers drei mōl. $(L h, N a)$ 
To cure marasmus : cover the back of the child with honey at night, and next morning scrape it with the back of a razor. This should be done three times.

Man schabt ihn mit einem messer ab. Hlbg.

1471. Fer a ab'nemmes fit'dert mers kind aus 'm katze schærbe $(D, L b, L n c, N u, S c)$; ąちer di katz gēt dōd. $(L b)$

For marasmus, feed the child from the cat's dish; but the cat will die.

1472. Fer a ab'nemmes mạcht merm kind supp, fidert si 'm aus me neie blettche, â̄ôr mer muss der katz å dēl gebe. Des dut mer drei mōl. (Be, D,Lb,Lh,Lnc, $M t, N u, S n, Y$ )

For marasmus, give the child soup from a new saucer, but the cat should be given some of it. This should be done three times.

1473. Wammer leibschmærze hot soll mern bitters drinke â̋ers glås mitkåfe. $(C, L h, S c)$

To cure griping, drink bitters, but pay for the glass also.

1474. Fer seitschteche: hēb en schtē ${ }^{\sim}$ uf, schpau dreimol druf un schmeiss en hin'nerschich wek. ( $B e, B u, C$, $D, L b, L h, L n c, M t, N a, S c, Y$; Heidelberg)

To stop stitches in the side, pick up a stone, spit on it three times and throw it backwards over your shoulder.

1475. Wammers schteche in der seit hot soll mern schtē ufhēbe, dreimōl druf schpaue un en wider hĩ lēğe gråd wì er wår. $\quad(B e, B u, D, L b, L h, M t, N u, S c, Y)$ To stop stitches in the side (pleurodynia): pick up a stone, spit on it three times and put the stone back in its place.

Wenn man seitenstechen hat, nimmt man einen stein auf, spuckt ihn auf jener seite, auf der er lag, und legt ihn an die frühere stätte. Dies hilft. $Z \mathbf{1 7 9}$ 
1476. Mer grikt der grạmpp net wạmmer schwimme gët wạmmers êrscht uf en schtẽ schpaut un en nō 's unnerscht 's e'terscht hĩ lēkt. (Be; Freiburg) To prevent cramps when swimming, pick up a stone, spit on it and replace it upside down.

1477. Wạmmer schwimme gēt muss mer uf en schtẽ $\tilde{}$ schpaue un en nō ins wassser schmeisse, nō grikt mer der grampp net. ( $B e, B u, C, D, L b, L h, L n c, M t, N a$; Freiburg)

Before starting to swim, pick up a stone, spit on it and throw it unto the water. This will prevent cramps.

1478. Wạmmer der schlixer hot soll mer sich fōrbìğe sō ą di hend uf der bo'dem rēche un dreimōl såğe: o schlixer, ich wott, du wæ̈rscht in meim årsch. (Lh; Lustnau)

To stop hiccough, bend forward so that the hands touch the ground and say: $O$ hiccough, I would you were in my buttocks.

1479. Wạmmern gewex' an sich hot, soll mer me dōde en bendel um der finger binne un seller bendel nō ums gewex', a $\mathrm{a}^{\prime}$ Ђern wider runner nemme fær der leicht un en in dii låd lēğe. 'S gewex' fergēt wann der bendel ferfault is. $(D, L b, L h, N a, S n)$

Cure a tumor by tying around it a string which had been tied around the finger of a corpse. Remove the string and put it in the coffin, and the tumor will disappear when the string has decayed.

1480. Bettpisser gebt mer en gebrōt'ni maus zu esse $(C$, $L n c, M r, N a$ ) oder mer bakt ne en pei fun meis un fí'derts ne. ( $L b, M t, N a)$

Fried mouse or mouse pie cures bedwetting.

Pissen kinder in das bett, so gebe man ihnen eine gebratene maus zu essen. $Z 45$

1481. En bettpisser losst mer in en gråb pisse, nō fergē'ts. $(B e, C, L h, L n c, N a, S n, Y$ ) 
A child that wets the bed should piddle into a grave.

Gegen das bettpissen ist gut, wenn der pisser nachts um zwölf uhr auf den kirchhof geht, wenn gerade ein frisches grab geöffnet worden ist und keck in dasselbe hinein pisst. Er wird von stund an das bett trocken lassen. A S 1.406

Those who suffered from a weak bladder had to stand astride at the head of an open grave after the coffin had been lowered but before being filled in, and then walk backwards to the foot of the same. $B l N R 146$

1482. Me bettpisser fidert mer en wærschtel fume sei'fetzel gemacht. ( $\mathrm{Be}, \mathrm{Lh}, \mathrm{Mr}, \mathrm{Y})$

If a child wets the bed, it should eat a little sausage made of the pudendum of a pig.

Man gibt dem bettpisser die pudenda eines schweines gebraten zu essen, ohne dass er es weiss. $L V 136$

1483. Wann kinner ins bett pisse, gebt mer ne en gebrōt'ni maus zu esse. $(C, L b, L n c, M r, N a)$

To cure bedwetting in children give them a fried mouse. Pissen kinder in das bett, so gebe man ihnen eine gebratene maus zu essen. $Z \mathbf{Z 5}$

The mouse, being roasted, is good to be given to children that piss their bed. $V S L 2.503$

1484. Bletsch me bettpisser der årsch mit der satzbritsch oderm hudelwisch. (C,D,Sc; Lustnau)

Spank the bedwetter with a yeastladle or a bakeoven mop.

1485. En bettpisser wipt mer mit me hu'dellumbe. (Be, $L b, Y)$

Whip a bedwetter with a bakeoven mop.

1486. Me bett'pisser schpellt mer kēs'banale an der årsch. (Bu; Kaiserslautern)

Cure a child of bedwetting by putting common mallow (Malva rotundifolia) on its posteriors.

1487. Wip en bettpisser mit re wip a as in ēm jōr giwaxe is. $(S n)$ 
Whip a bedwetter with a yearling twig.

1488. Ferbrech en zann'me gibąk'ner lēb brōt țerm kopp fume kind as ins bett pisst. Sell schtopts bettpisse. $(B e, C, D, L b, L h, N a, Y)$

To cure bedwetting break a twin loaf over the child's head. Einem kinde, das schwerlich reden lernet, soll man ein in backofen zusammen gebacken brodt über dem kopf von einander brechen. $G R 854$

1489. Mer dråkt en schtreissel ē'renpreis im sâk nō, nō wært mer de gañze dåk net míd. (Be, Lh, Mt)

Carry a sprig of speedwell (Veronica officinalis) and you will not be fatigued all day.

Zum wandern, dass man nicht müde wird, nimm zu dir beifuss oder eisenkraut, so wirst nicht müde, es beisst dich auch kein natter oder hund. Alem 16.59

1490. Der dokter dærf mer net ganz a ab'bezåle schunscht muss mern glei wider hōle. ( $B u, D, L b, L h, L n c$, $M r, M t, N a, S n, Y$; Freiburg)

You mustn't pay the doctor in full or there will be a sickness in the family. $C S A 1282$

1491. Wănn ebber der schlixer hot kąmmern ferdreibe wạmmer såkt: dū hoscht ebbes gschtöle. ( $A f$; Heidelberg)

A remedy to cure hiccoughs is to scare the person by saying: you have stolen something.

1492. Wạnn ëns å gewaxe is muss es dreimōl hinnerschich ums dischbē $\bar{e}^{-}$gradle. (Af)

When livergrown, crawl three times round the leg of a table backwards.

Bei dem "anwachsen" wird das kind dreimal durch die stuhlbeine oder durch leitersprossen gesteckt. $W u 338$

1493. Wănn em di nås blūt soll mern schtē ${ }^{-}$ufhēbe, drei droppe blūt druf dropse losse un der schtē wider ht lēğe, gråd wt er wår. (Af) 
For nose bleed: pick up a stone, let three drops of blood fall on it and put the stone back in its original place.

Gegen das zahnweh: man hebe ungesehen einen stein von der strasse auf, speie dreimal auf die seite hin, auf welcher er gelegen war und setze ihn wieder so an die stelle, wie er vorher gelegen hatte. $V A S 483$

1494. Wannd wund bischt hok dich mit em blōsse årsch uf frisch geblūkter grund. $(M r, S c, S n)$

When chafed in the erotch sit with bared posteriors on newly ploughed soil.

For a sore leg the fairies recommend earth, but particularly red clay of a certain small loch. $S H S 61$

1495. Fer wund, schprē feiner wēze schtåb dri’łer. (Be. Mr; Heidelberg)

Put wheat dust on any chafed parts of the body.

1496. Fer wund unich de ǣrm reib frischer grund druf. $(B u, C, M r, S n, Y)$

When chafed under the arm pits, rub fresh ground on the parts.

1497. Fer wund soll mer bitter wær'mūt im sâk nōdråğe. $(B e, D, L n c, S c, S n, Y)$

When chafed carry bitterweed (Ambrosia artemisiacfolia) in the pocket.

1498. Wammer wund is zwische de be ${ }^{-}$roppt mer hollerlåb a a wū der då noch druf is un lēkts druf. $(C$, $M r, S n)$

When chafed in the crotch put on elderberry leaves fresh with dew.

1499. Wămmer wund is muss mer hollerlåb ąbroppe wū der då noch druf is un im såk nō dråğe. $(B e, C, L h$, Lnc, $\mathrm{Mr}, \mathrm{Mt}, \mathrm{Na}, \mathrm{Y}$; Freiburg)

When chafed pluck elderberry fresh with dew and put them into your pocket.

1500. Mēr'reddich is gūt fer rōtlåfe. ( $N a, S c ;$ Freiburg) Horse radish is good for inflammation. 
1501. Sei'ōre bletter sin gūt fer rōtlåfe. $(C, S c)$

Common plaintain leaves (plantago maior) are good for inflammation.

1502. En weissi zwibel ztkt gift aus re wund. $(C, S c$; Heidelberg)

Tie a white onion on a wound to neutralize the poison.

1503. Fer lakk'tschå, glopp rōtrtbe bletter, binn si in en lumbe un dũ $\tilde{\sim}$ si uf di wund. (Lnc)

Crushed leaves of beets (Beta vulgaris) put in a rag and tied on a wound will cure lockjaw.

1504. Wạmmer frisch gegråt'ne rōtritநe uf en lạk'tschå wund dut, zìkts 's gift raus. (Be, $L h, S c, S n)$

Fresh beets (Beta vulgaris) cure lockjaw.

1505. Rōtrîte bletter sin gūt fer rōtlåfe. (Af; Freiburg) Beet leaves are a cure for inflammation.

1506. Kilwassser mạcht en schē'ni weissi haut. (Be, $B u$, $C, L b, L h, M r, N a, S c)$

Water in which a blacksmith has cooled his iron makes a beautiful, white skin.

Krätzige sollen sich mit wasser waschen, worin der schmied glühendes eisen gelegt hat. $V A S 1.486$

1507. Uf der Him'melfærdåk sạmmelt mer tē fer rūr. (Be, $B u, C, D, L h, L n c, M r, N u, S c, S n, Y)$

Herbs for dysentery should be gathered on Ascension day. An St. Johannis des Täufers tag sei wider allerhand krankheiten und zustände des leibes gut wurzel und kräuter graben. A S 1.379

1508. Wǣrs kǣrfåre net schtende kannn soll sich en bōğe schreibbąbir' uf di bruscht lëğe. ( $L h, L n c, M t, S n$, $Y)$

Wearing a sheet of writing paper on the chest will prevent carsickness. 
1509. Wămmer hært kąlt hot soll mer wiski brenne un ótbeds eb mer ins bett gēt defun' nemme. I'berm brenne soll mer ă̄orer der wiski dreimōl ausblōse un wider å schteke un nō brenne losse bis er ausgebrennt hot. $(A f)$

To cure a heavy cold drink some burned whisky before going to bed. During the process of burning the whisky the flame should be extinguished and relit three times, after which it should be permitted to burn until all the alcohol is burned out.

1510. Wǣrs hærzglobbe hot, soll en schtē $\bar{e}^{\sim}$ ufhēbe, dreimōl druf schpaue un en nō hinnerschisch wekschmeisse. (Be, Bu, C, Lb, Lh, Mt, Na, Nu,Sn, Y; Freiburg) Cure palpitation of the heart by spitting thrice on a stone and throwing it backwards over your shoulder.

1511. Grē åğe schneit mer in der Wōk.

Cut corns in Libra.

1512. Grēn'åğe schneit mer im ăb'nemmede. (Af)

Cut corns in the decrease of the moon.

Alles, was abnehmen soll, muss bei abnehmendem mond geschehen. $W u 57$

1513. Der schnuppe lōs zu wærre, får mit de finger zwische de zēe dærich un rích nō drå . (Be,C,Lh, Mr, $N a, N u, S c, S n$ )

To cure coryza, pass your finger between your toes and smell it.

Für den schnupfen-wenn du deine schuhe und strümpfe ausziehst, so fahre mit dem finger durch alle zehen und rieche daran. Hoh 13

1514. Fer heibs, reib dich ąme sei'drok. $(M t)$

To stop hives, rub yourself against a pig's trough.

1515. Wămmer mit der schtærn ærğets weder schtōsst, sō ass es en gnopp gebt, drikt mer mit re messergling druf, nō gēt der gnopp wek. Des is å gūt fer blōe ăğe. (Lh) 
Press a knifeblade on a bump on the forehead or a black eye.

Wenn ein kind auf den kopf fällt, drückt man mit einem messer kreuzweise auf die stelle, so wird keine beule. Wu 395

1516. Gummereschåle tē is gūt fer grạnp. (Mr; Heidelberg)

Tea made from encumber peelings is good for cramps.

1517. Wănmer finf finger graut im såk nō dråkt wært mer net fergess'lich. $(D, L b, L h, M r, S n)$

Carry cinquefoil (Potentilla Canadensis) to prevent forgetfulness.

1518. Wăsser fun Kærfrei'dåks schnē is gūt fer wēe åğe. $(D, Y)$

Water from snow which fell on Good Friday cures sore eyes.

Augenkrankheiten werden geheilt durch Osterwasser. $W u$ 349

1519. Schmeisz en schip foll feier iちer di fei'erich rōs. $(B e, C, D, L b, L h, M r, M t, N a, N u, S c, S n)$

Throw a shovelful of hot coals over the part of the body afflicted with erysipelas.

1520. Mer muss brauche losse for wildfeier. (Af)

Powwowing cures erysipelas.

Die rose wird oft besprochen. $W u 172$

1521. Wǣr di fei'erich rōs oders wildfeier hot, soll sich feier mit schtål un feierschtē $\sim$ drið̄er schlăğe losse. $(B e, C, D, L h, L n c, N a, S c, S n, Y$ )

To cure erysipelas, strike sparks over the afflicted parts with flint and steel.

Die rose wird geheilt, wenn der kranke sich von jemand, der mit ihm gleichen taufnamen hat, mit stahl und stein funken darauf schlagen lässt. $G 3.383$

1522. Fer schnuppe, får mit em finger dærich der årsch un rłch no drå̃. $(S c, S n)$ 
For a cold in the head pass your finger over your anus and smell it.

1523. Drik en bruch zurik' mit schwærzwærzel un halt si druf bis si wårm is; nō blanzt mer di wærzel un wănn si wakst gët der bruch wek. $(B e, S c, Y)$

Reduce hernia by the use of blackroot which should be held on the hernia until warm. It should be then planted, and if it grows the hernia will be eured.

Brüche werden reponiert und frisch ausgehobene pflanzen vom bruchkraut, sedum telephium, oder eine zwiebel auf die bruchstelle gebunden, welch' letztere man nach einiger zeit umgekehrt wieder in die erde pflanzt. $L V 119$

1524. Wăn ebbes en fell ibers åk grikt, henkt merm en fellgnopp $\mathfrak{a}^{\sim}$. Der fellgnopp is en sak fun ungewesche duch gemacht; in der sakk dut mer brōt, sa्nlz un wēze. Nō henkt mern dem å as es fell hot, àme bendel wū ken gnopp nei ${ }^{\sim}$ gemacht is. Mer muss en henke losse, bis er fun selbert ånfạllt. (Bu, Lh, Mt, $S c, S n)$

If a person or animal develops a false membrane over the eye [diphteritic ophthalmia? or paunus in keratitis? or opacity in cataract] suspend from its neck by a string in which there are no knots a bag made of unwashed material and containing bread, salt and wheat. Wear this bag till it drops off of its own accord.

In der Pfalz werden "wehe augen", besonders flecken an menschen und vich geheilt mit der "augenblume" auf dem blossen rücken getragen. Sie besteht in einem säckchen aus grauem ungebleichtem tuch, worin einige körner salz, brod und kampfer sind. $L V 227$

1525. Wạnnd der schlixer hoscht, drink wassser un denk an ēns a a dich gleicht. (Mt, $S c)$

To cure hiccoughs, drink some water, at the same time thinking of some one who loves you.

1526. Fer schlixer drink drei, sibe oder nein schluk wăsser une gschnauft. $(C, M r)$ 
To stop hiceough, drink three, seven or nine swallows of water without taking breath.

1527. Wǣr der schlixer hot, soll sex schluk wasser drinke une gschnauft. (Af)

To stop hiccoughs drink six swallows of water without taking breath.

Wenn man den schnaggel hat, muss man neunmal wasser schlucken, ohne atem zu ziehen. $Z 220$

1528. Blūt kânmer schtille, wạmmers sa्nkmesser aus ēm sakk in der anner dut. (D, $Y$; Lustnau)

To stanch a hemorrhage, transfer the pocket knife from one pocket to the other.

1529. Dem wū der schlixer hot hēbt mern sạkmessergling uf di zung. (D, $Y$; Kaiserslautern)

Press the blade of a pocket knife on the tongue of the person suffering with hiccough.

1530. Des wũ der schlixer hot, soll denke wǣrs nēkscht zum kokt hot in der kærich, 's letscht mōl as kærich wår. $\quad(N a)$

To stop hiccough try to recall who sat next to you in church at the last service.

Schlucker vergeht, wenn man an die reihe denkt, wo man zuletzt in der kirche stand. $L V 241$

1531. Wạnn ebbers wildfeier hot, nemme si sei wassser zum hexe dokter. (Lb, Lnc, $\mathrm{Na}, \mathrm{Y}$; Heidelberg) To cure erysipelas, the patient's urine should be taken to the witch doctor.

Water-kester, a mediciner who professes to tell the disease by the cast or appearance of the urine. $C F Y 2.171$

1532. Dū $\sim$ milich fun schēlgraut uf ime oder hummle schtich. $(B u, M t)$

Put the milk of celandine on the sting of bees or bumble bees.

1533. Di milich fun schēlgraut ferdreibt gift. (Na)

The milk of celandine (Chelidonium maius) kills ivy poison. 
1534. Dũ $\bar{e}$ às di fạllet granket hot 's hemm letz aus un lēks me dōde unich der kopp in di låd. ( $L h, L n c, Y$; Heidelberg)

To eure epilepsy, remove the sufferer's shirt wrongside out and place it in a coffin under the head of a corpse.

In Aberdeenshire, when a man is first seized with epilepsy, his clothes should be burned on the spot where he fell. B F 72

1535. Wann dich en tm schtecht, hēb en tschå’dewak druf. (Lnc, $Y$ )

For bee sting put a tobacco quid on it.

1536. Fer Ime schtich, hēb lette druf. $(M r)$

Apply clay to a bee sting.

Use the mud remedy for wasp stings. $F \quad B \quad 8.389$

1537. Wạn em en im schtecht nemmt mern schibl lette, brunst druf, macht en mē oder we'nicher dinn un hēbt en nō uf der schtich. Sell zîkts gift raus. (Be, $D, L b, L h, L n c, N a, S c . S n, Y$; Heidelberg)

To stop the smarting of a bee sting apply some clay kneaded and thinned with urine.

1538. Wå'sem 's un'nerscht 's eந̄e'rscht gedrēt' un un'ichs bett gelēkt soll helfe as en grankes sich net ufleit. (Be, Lnc, Sn, $Y$; Ettlingen)

Sod turned upside down and placed under the bed prevents bedsores.

1539. Wi'kel en glēd wū ēns drin gschtærø̄e is ums dēl wū de gramp hoscht, nō fergēt er. (Lnc, $Y$; Freiburg) Wrap the garment, in which a person died, round the parts afflicted with eramps.

A piece of the linen wrap taken from a corpse will cure the swelling of a limb if tied round the part affected. Ir 1.154

1540. Fer gēlsucht: hil'ich en gēl'rtb aus, dũ $\sim$ fum patsient' seim wassser nei ${ }^{\sim}$ un henk si in der schann'schte $\tilde{e}^{\sim}$ in der schmōk. (Be, $C, L h, M r, S c, Y)$ 
For jaundice: hollow out a common carrot (Daucus carota), fill it with the patient's urine, then smoke it in the chimney or hearth.

Gegen gelbsucht: man füllt eine ausgehöhlte mohrrübe mit wasser oder mit dem harn des kranken und lässt sie im kamine vertrocknen. $W u 339$

In Staffordshire, to cure jaundice, a bladder is filled with the patient's urine and placed near a fire; as the water dries up, the jaundice goes. $B F 56$

1541. Wănmer sich an ebbes schneit oder fergrătzt brunnst mer uf di wunt. $(A f)$

Urinate on a cut or scratch.

1542. Fạng en grot un hēb si uf di wund. Wănn si dōdgēt, fang noch ēni un hēb si druf, un so fært bis si lebendich uf der wund bleibt. Des is en schūri kjūr fær schlange biss. (Lh, Lnc, Sc; Heidelberg)

To cure snake bite: Catch a toad and tie it on the wound. If the toad dies, repeat the operation until the toad remains alive.

Als besonders heilsam gegen geschnittene wunden gilt menschenharn, für gerissene der kot. VAS 1.487

Gegen den krebs der brust des weibes hilft eine kröte, drauf gebunden, nachdem man vorher über dieselbe das krcuzeszeichen gemacht hat. $V A S 1.485$

In some districts it is believed that a toad, proverbial for being poisonous in itself, be applied to a cancer, it will suck out the poison of the disease and thus cause a cure. $V S L 2.2 .488$

1543. Fer gichtre gråb drei gle'dewarzel fun dem jōr un schneit jēder wærzel in drei schtiker, fēdel si ei ${ }^{\sim}$ un henk si em kind $\AA^{2}$. $\quad(I h, L b, M r, S c, S n, Y)$

To cure convulsions: dig three burdock roots (lappa officinalis) of that year's growth, cut each into three pieces, thread them and wear them.

Dann werden die kinder nicht krank. Hlbg.

For convulsions, wear a necklace of beads turned from the root of the peony. $V S L 2.2 .491$ 
1544. Ōschtersunndåks soll mer Kærfreidåksoier esse, nō grikt mer ken bruch. (Be, Lh, Mr, Sn)

To prevent hernia you should, on Easter Sunday, eat eggs laid on Good Friday.

Karfreitagseier, am Ostersonntag nüchtern gegessen, behüten vor bruchschaden. $W u 74 ; V S L 2.1 .224$

1545. Wămmer wēe åğe hot un sēnt ebber ås mer schun lạng nimmi gsēne hot, kjūrts si. ( $N a ; N e u s t a d t)$

Seeing a person whom you have not seen for a long time cures sore eyes.

The sight of ye's good for sore eyes. Irish; $A J F 5.116$

1546. Lēk en sauberer schpinnewēb uf en wund ans $\mathfrak{x}^{\prime}$ rik blūt. (Af; Heidelberg)

A fresh cobweb will staunch the flow of blood.

The spider's web is an excellent styptic. W Ir 27

1547. Wănn ēns ōrewē hot soll merm di grol'lichscht hỏr as mer a ame niğger finne kann ins ōr dū̃. (D, Lnc, $M t)$

To cure earache, put into the ear the kinkiest hair to be found on a negro.

Some wool taken from a black sheep and worn constantly in the ear is a sure remedy for earache. W Ir 27

1548. En schtik schtrik wū en mensch sich kenkt hot mit kjūrt fạllet granket. ( $B e, L b, L n c, S n, Y)$

A piece of the rope with which some one has committed suicide will cure epilepsy.

Aus dem nagel, an welchem sich einer erhängt hat, schmiedet man eiserne ringe, welche gichtkranke an der rechten hand tragen. $W u 138$

A halter with which one had been hanged was regarded within recent times as a cure for headache, if tied round the head. $B$ F 100

1549. Fer nåsblūte, lēk en silter schtik ins hălsgnik. $(C$, $M r, M t, S c)$

Press a silver coin on the back of the neck to stop nose bleed.

Lege etwas recht kaltes in das genick. Hlbg. 
1550. Der ērschte grot âs mer fríjōrs im gårte sēnt schneit mers recht $b \bar{e}^{-} \mathfrak{a} b$, duts in en sak un henkts $\mathfrak{a}^{\sim}$. Sell ferdreibt di weitschwelling. (Lh; Kaiserslautern) Cutting of the right leg of the first toad seen in a garden cures synovitis.

To cure violent fits, kill a toad, put one of its legs in a bag and wear it suspended by a string around the neck. Corn 154

1551. Fers bēsding' soll mern maulwærf hē̄e bis er dōd is. (Be, Lb, Lnc, Mt $, S c, S n, Y$ )

A mole held in the hand until dead will cure a felon.

Wenn man einen maulwurf in der hand langsam sterben lässt, so kann man mit dieser hand allerlei übel heilen, besonders den wurm im finger, beulen u. s. w. $W u 315$ The touch of a man who has caught a mole and rubbed it slowly and gently between his hands until it dies, will work a cure. B $F 161$

1552. Mer soll gamber in en sak nēe un en sich winters uf di haut uf di bruscht henke, no bleibt mer der ganzz winter gsund. $(B e, L h)$

Wear on your chest next to the skin a small bag containing camphor. This will ward off sickness during the winter.

Some carry on their person a small bag containing camphor under the notion that it wards off any kind of infection. D Eng 168

1553. Wạmmer ebbes wẽes obe uf der hand hot soll mer håse fett ine'wennich in di hand $\overline{d u}^{\sim}$; sell dreibts wek. (Be, C, D, Lh, Mt, Nu,Sc,Sn; Heidelberg) The fat of a rabbit put in the palm of the hand will heal a sore on the top of the hand.

Var. Schir ë'nich fett duts. (Bu, Mt) Almost any fat will do the same.

1554. En wårmer kì'drek pōltis nemmt rōtlåfe aus re wund oder zikt en gschwæ̋re zạmme. (Af)

Poultice a wound with warm cow dung to reduce inflammation or to draw a boil to a head. 
Auf die geschwollene hand, das geschwollene bein, lege man mist. Alem 27. 229

In the south of Hampshire a plaster of warm cowdung is applied to open wounds. $B$ F 161

1555. Unich me dærn'eschtok a as obe zammegewąxe is dærich schluppe is gūt fer der hūschte. Mer muss ăber gēğich sunnuf dærich schluppe. (Lh, Lnc)

To cure a cough, erawl toward the east underneath a briar which has taken root at both ends.

A child with whooping cough should be drawn backwards through a bramble rooted at both ends. V $S L 2.500$

Vielfach kommt ein abstreifen der krankheit vor, welches, wenn es durch astlöcher, baumspalten etc. geschieht, sich mit dem übertragen auf bäumen berührt, aber auch durch hohle steine, leitersprossen und andere ein durchkriechen ermöglichende dinge geschieht; es sind fast lauter dinge, die an sich eine heilige geltung haben, also als heilend und unheilabnehmend gelten; natürlich wird es meist nur bei kindern angewandt. Lahme müssen vor sonnenaufgang schweigend durch eine gespaltene eiche kriechen. Rückgratsverkrümmungen heilt man, indem man das kranke kind einigemal durch einen aus der erde herausgewachsenen bogen einer wurzel zieht $\mathrm{u}$. s. w. $W u 337$

1556. Wănmer en weeer hâls hot soll mer en wollner schtrump um der halls binne. (Lb)

Tie a woolen stocking about a sore throat.

1557. Wạmmern wēer hâls hot soll mer der links schtrump um der hals binne. (Af)

For sore throat wear the left stocking around the neck.

Halsschmerzen und heiserkeit heilt man, wenn man sich abends einen linken oder umgedrehten strumpf um den hals bindet. $W u 357$

For sore throat apply as a wrapping for the night the sole of a stocking taken warm off the foot. $V S L 2.512$

1558. Wămmer unferschtērt un rūich schlöfe will wånmmer im bett is, secht mer:

Kopp schlōf, årsch wąch.

Wạnn ebbes kummt, dąnn grąch. (Af; Freiburg) 
If you would sleep soundly all night, say:

Head, sleep on; buttocks, stand guard!

Should any one come, sound the alarm.

1559. Wămmer me mensch sei schtūlgang ferbrennt grikt ern wēer årsch. $(B u, L b, L h, M t, Y)$

Burning human feces causes a sore anus.

1560. Wǣr ă der wēk scheisst grikt en wek'schisser. (Be, $B u, D, L h, L n c, M t, S c, S n, Y$; Heidelberg)

If you defecate along the roadside you will get a sty.

1561. Draube bletter sin gūt fer rōtlåfe aus ebbes nemme. $(B e, C, D, L b, L h, L n c, N a, N u, S c, S n)$

Grape leaves reduce inflammation.

Nimm wilde traubenblätter, bähe sie beim feuer, dass sie ein wenig welk werden; lege sie des abends, wenn du zu bette gehen willst, auf den geschwulst, wiederhole es einigemal, so wird der geschwulst gewiss vergehen. Ho 49

1562. Nemm Mærien'wærzel pår zoll lăng, schneit si in bla tre un fēdel si ungrad ei un dū ${ }^{\sim}$ si a . Der neint dåk duscht si aus un fēedelscht ănnere gråd sō ei ; un sō dreimōl, â̄̄er gråb si âllemōl un'ich der dạchdrạp, nō gēt ălles ausfårisch, flis'sich oder grin'dich ewek'. (Be, D, Lb, Lh, Nu, Sc)

To cure scrofula: dig the roots of wild marjoram (origanum vulgare), cut them crosswise, thread an uneven number of pieces and wear them as a necklace. Remove them on the ninth day, threading others; repeat twice, each time burying them under the eaves.

Man kann drei klettenwurzeln an einem Freitag vor der sonnen aufgang ausgraben, von jeder wurzel drei rädlein schneiden, in ein tüchlein nähen, über das schwindende glied binden und es zwei bis vier tage lang darauf liegen lassen, hernach es wieder wie zuvor nehmen, und so lange gebrauch davon machen, bis das glied nicht mehr schwindet. Die wurzeln mögen grün oder dürre sein, welches gleichviel ist, wenn sie nur an einem Freitag vor der sonnen aufgang gegraben worden sind. Ist an vielen menschen und vieh probiert worden. $A M 1.20$ 
1563. Binn en wollner bendel um en ferschtrēnt oder ferrenkti hand. $(D)$

Tie a woolen cord around a sprained hand or wrist.

1564. En schpinn an der hạls kenkt kjūrt kạnlt fitber. (Be, $C, L h, L n c)$

Suspending a spider from your neck will cure ague.

Gegen fieber: man näht drei spinnen ohne sie mit bloszer hand anzufassen in ein beutelchen, trägt es zwei tage am halse und wirft es dann rückwärts in ein wasser und läuft ohne sich umzusehen nach hause. $W u 335$

Elias Ashmole, who was suffering from ague, hung three spiders about his neck and they took his ague away. Deo gratias. $B F 60$

1565. En gropp reibt mer mit me dōde gnoche. (Sn)

Rub a goitre with a bone from a carcass.

Den kropf bestreicht man mit totenbeinen, u. s. w. $\quad W u 349$

A goitre will disappear if rubbed with the hand of a corpse. $H N C 153$

1566. En geweks' schtreicht mer mit der hand fume dōde, nō gēts wek sō schtæ'rik ass der dōd ferfault. (Be, $C, D, L b, L h, L n c, M r, N u, S c, Y$ )

Stroke a tumor with the hand of a corpse, and it will disappear with the decomposition of the corpse.

Man bestreiche die krankheit mit einer totenhand. Die leiche nimmt die auf sie übertragene krankheit mit ins grab; das gilt besonders von haut- und andern äusserlichen krankheiten. $W u 334$

In Storrington not many years ago a young woman afflicted with goitre was taken by her friends to the side of an open coffin that the hand of the dead should touch it twice. $B$ F 101

1567. En mut'termōl muss mer mit re dōde hand schtreiche, nō gēt si wek. (Af; Freiburg)

A birthmark will disappear if rubbed with the hand of a corpse.

The belief in the efficacy of a dead hand in curing diseases in Cornwall is marvellous. Corn 152 
1568. Gensfett is gūt fer schier è'nich ebbes. (Af)

Goosegrease is good for almost any ailment.

Bei catarrhalisehen leiden empfiehlt man hals und brust mit gänsefett einzureiben. $L V 240$

Her [goose] grease is excellent (Probatum est)

For such a numbness in their joints molest;

For the Sciatica, Cramp, or Gout.

It either cures or eases, out of doubt. $V S L 2.497$

1569. Wạsser fun schnē as es im Mærz gebt is gūt fer schwąche åğe. (Af; Heidelberg)

March snow water strengthens weak eyes.

Catch the last snow of the season (e. g., in April), melt and put into bottle. It will cure sore eyes. $C S A 838$

1570. Un'gsalsner butter is gūt fer wunde hēle. $(B e, L h)$ Unsalted butter has healing properties.

Ungesalzene Gründonnerstagsbutter heilt alle wunden. $Z$ $f V 1891,180$

If during the moneth of May before you salt your butter, you save a lumpe thereof and put it into a vessell, and so set it into the sun for the space of that moneth, you shall find it exceeding soveraigne and medicinable for woundes, straines, aches, and such like grievances. $V \mathrm{~S}$ $L 2.506$

1571. Reib en wēk'schisser mit me hochzichring. (Lb)

Rub a stye with a wedding ring.

Rub stye in the eye with a plain gold ring, preferably a wedding ring. $V S L 2.514 ; C P$ \& $P 205 ; C S A 866$

1572. Mer soll di haut fun re ōl às im Moi gfange is wærre um en glìd as ferschtrēnt' is wikle. (Be,C,Lh, Lnc, $M t, N a, S c$; Heidelberg)

To cure a sprain wrap the skin of an eel caught in May around the parts.

Var. 1. ....im Mærz $(L b, M t, N u, S n)$ in March

Var. 2. .... èn'ichi ōlehaut. ( $B u, L b, L h, N a, N u$, Y) 
any eelskin.

Eelskins are wrapped round the wrist as a prevention of sprains. $V S L 2.512$

1573. Wannd dich hakscht mit re ax schmir si mit fett un lēk si unichs bett. $(A f)$

After you have cut yourself with an axe, cover it with grease and lay it under the bed.

Bei einem erlittenen stich oder schnitt oder bei einem tritt in einen nagel soll man unberufen das verletzende werkzeug sogleich mit fett oder wagenschmiere bestreichen und an einem unzugänglichen ort aufheben. $L V 205$

1574. Di ąx wū mer sich mit hakkt soll mer mit fett schmire un im druk'ne halte. ( $A f)$

If you cut yourself with an axe, grease it with lard and keep it in a dry place.

Hat man sich geschnitten, so bestreiche man das messer oder die schere, womit man sich verwundet, dick mit fett und lege sie unter nennung der drei heiligen namen an eine trockne stelle. $W u 345$

1575. Wạnnd in en năğel drētscht, schtek en in fett un gråb en nō un'ich der dąchdrąp. (Af)

Put the nail, into which you have stepped, into fat and bury it under the eaves.

1576. Wạnnd in en năğel drētscht, ropp der năğel raus, schtek en in fett un hallt en im drukne. ( $A f)$

After having stepped on a nail, pull it out, put it in fat, and keep it in a dry place.

Wer sich schneidet oder schticht, muss das messer oder die schere dick mit fett beschmieren, und in den drei heil. namen an eine trockene stelle legen. Sobald das messer dann trocken ist, wird das wehe heil. $Z f D M 1.199$

In the midland country, to cure a horse lamed by a nail, the farmers will thrust the nail into a piece of bacon and wait for the foot to heal. $B F 55$

1577. Wạnnd in en năgel drētscht, ropp en raus, schtek en in fett un schtek en nō in der schan'schtẽ ${ }^{\sim}$. (Be, $L b, M r, Y$ ) 
If you step in a nail, pull it out, put it into fat and then in the chimney [i. e. fireplace].

A man, who "stuck a nail in his foot," was told by a neighbor to pull it out, grease it and hang it up in the "chimbly," otherwise he might have lockjaw. C S A 819

15̃78. Wămmer sich mit ë'nich me schneitgschærr wẽ dut, soll mers gschærr gūt eirschmire oder zū binne, nō hēlt di wund glei. $(B e, B u, C, D, L b, L n c, M r, M t$, $N a, N u, S c, Y$ )

The edged tool with which you have cut yourself should be well greased or wrapped up, so that the wound will soon heal.

Wenn man sich mit einem messer oder einer sense beschädigt hat, soll man nicht nur die wunde, sondern auch das werkzeug, mit dem der schaden verursacht wurde, fleissig verbinden. Dadurch wird die wunde so geheilt, dass nicht einmal eine narbe übrig bleibt. $Z 222$

The knife with which a man has cut himself should be rubbed with fat, that the healing of the cut may be hastened. BF 55

1579. Wămmer der mumps hot reibt mer sich anme sei' drōk. (Af)

When suffering with mumps, rub the swollen part on a pig's trough.

Ein schleissen vom sautrog hilft wider die "augenwärrle", wenn man mit einem solchen span das auge dreimal bestreicht. $V A S 1.484$

Wrap the child in a blanket, take it to the pigsty, rub the child's head to the back of a pig and the mumps will leave it and pass from the child to the animal. Ir. 2.95

3580. Schtreich en schuss'blōder mit re dōde hạnd. (C, Sc)

Pass the hand of a corpse over hordeolum.

A dead man's hand is supposed to have the quality of dispelling humors. $F R 1.227$

1581. Hēb on schmutzicher deller uf en wèkschisser. ( $L h)$ Hold a greasy plate on a sty. 
1582. Fer schuss'blōder braucht mer mit me schmutziche deller. $(B e, C)$

Powwow for sty with a greasy plate.

1583. Wạmmern schussblōder odern wēkschisser ąm $\mathrm{k} k$ hot, muss mer en schmutz'icher deller åguke. (D, Lnc, $M r, M t, Y$ )

To cure a sty, look at a greasy plate.

Für die schossblattern hält man einen heissen irdenen deckel vor das auge, welcher die hitze aus dem auge ziehen soll. $L V 228$

1584. Fer nåsblūte binnt mern wollner bendel um der glẽ finger. $(A f)$

Tie a woolen string about the little finger to stop nosebleed. Gegen das nasenbluten: man binde den kleinen finger der linken hand fest mit einen faden zu. $V A S 1.480$

1585. Fer nåsblūte soll mer en rōter bendel um der hąls binne. $(A f)$

To stop bleeding of the nose, tie a red string round the neck. To prevent nosebleeding people are told to this day to wear a skein of searlet silk thread round the neck, tied with nine knots down the front. $B$ F 111

1586. Fer nåsblūte soll mern schtik zeiting bąbtr' e weil kaue. $(L h, L n c, M t)$

For nosebleed, chew newspaper.

1587. Fer nåsblūte kau bạbì' un driks unich di e'berscht lefts. ( $L b, L n c, Y)$

For nosebleed, chew paper and put it between the gums and the upper lip.

Bei nasenbluten empfiehlt man ein stückchen zusammengelegtes fliesspapier zwischen den gaumen und den unteren teil der zunge zu legen. $\quad L V 196$

1588. Fer nåsblūte schitt wasser der bukel nunner. (Lnc) Pour cold water down the back of the person suffering from nosebleeding.

Lege etwas recht kaltes in das genick. Hlbg. 
1589. Fer nåsblūte schitt mer kạlt wạsser ins gnik. (Af) Dash cold water onto the nape of the neck to stop nosebleeding.

Kalt wasser oder essig. $\mathrm{Hlbg}$.

1590. Drik en schtik silber unich di e'berscht lefts, wannn di nås blüt. ( $(B e, C, D, L b, L n c, M r, M t, N a, S c, Y)$ Press a silver coin against the gums and the upper lip to stop bleeding of the nose.

Nasenbluten hört auf, wenn man ein zweigroschenstück auf den oberen teil der nase drückt. $W u 347$

1591. Henk en schlissel uf der bukel, nås blūte zu schtope. $(\mathrm{Bu}, \mathrm{C}, \mathrm{Mr}, \mathrm{Na}, \mathrm{Sc}$ )

Hang a key down the back to stop nosebleed.

Gegen nasenbluten empfiehlt man einen schlüssel oder ein stück zwiebel in den nacken zu legen. $L V 197$

A key worn hanging about the neck by a string prevents nosebleed. C S A. 804

1592. Wạnn der di nås blūt denk wæ̈rs nēkscht zu der kokt hot in der kæ'rich 's letscht mōl a as kærich wår. (Lh) To stop nosebleed, recall who set next to you in church at the last service.

1593. En schlissel oder sent der bukel nunner falle losse schtopts nåsblūte. $(A f)$

Drop a key or a cent down the back to stop nosebleed.

Lege etwas recht kaltes in das genick. Hlbg.

The common remedy for nosebleeding is, slip a key down between clothes and skin. $B F 183 ; C S A 856$

1594. En ōle haut um der årm gebunne schtopt nåsblūte. ( $B e, B u, C, D, L b, L h, M r, N a, N u, Y$ )

An eelskin tied round the arm will stop nosebleed.

1595. En wund gschwind zu hēle, dū ${ }^{\sim}$ essich un hēmgemagchti sēf druf. $(M r, S c)$

To heal a wound quickly, apply vinegar and homemade soap. 
1596. So as en wund ken brannnt grikt, kocht mer ledde in essich un duts druf. ( $B e, L b, L h, L n c, N a, S n, Y)$ To prevent a wound from becoming gangrenous, put on it some clay boiled in vinegar.

Bei contusionen wird kaltes wasser oder lehm mit essig aufgelegt. $L V 204$

1597. Mer grikt ken wēer finger wąmmer schpinneneschter mit em finger lōsmacht. $(C, S c)$

You will not have sore fingers if you use your fingers in removing a spider web.

Wickle einen wehen finger in ein spinnweb. Hlbg.

1598. Wammern schpinn ferdrikt mit em finger grikt mer ken wēer finger. $(B e, L b, L h, L n c, M t, N a, N u, S c$, $S n, Y$ )

If you crush a spider with your finger, you won't have sore fingers.

Spinnen darf man nicht verdrücken. Hlbg.

1599. Wann en grankes recht færze kann is es uf der bessering. ( $C, D, S c, S n$; Heidelberg)

Breaking wind freely while sick in bed is a good sign.

1600. Wạnn en grạkes im bett nisst wærts wider gsund. (Af)

Sneezing while sick in bed is a good sign.

Wenn ein kranker niest, so wird er wieder gesund. Wu 219

He hath sneezed thrice: turn him out of the hospital. $\nabla$ $S L$ 2. 1. 304; $C P \& P 542$

1601. ' $S$ is en gūti sein wann sich me granke der bibs schtellt. $(C, S c)$

It is a good sign if a sick person has an erection.

1602. Wann ēns grank is im bett un schpærts maul uf is es en schlechti sein. ( $B u, L b, L h, L n c, M t, N u, S n, Y$; Heidelberg)

It is a bad omen for a person who is sick in bed to yawn. 
1603. Di drei ērschte kær'nēre âs mer frijōrs sēnt blte soll mer schluke mit de drei hōche wærte, no grikt mer sell jör ken fiber. (Mt; Heidelberg)

To prevent fever swallow the first three rye heads, which you see in spring, in the name of the Trinity.

1604. Wạnn ēns di făl'let granket hot, soll mer fun seine glēder ferbrenne. (Sn; Kaiserslautern)

Burn some of the clothes of a person afticted with epilepsy.

1605. Wạnn būbe schwimme gēn solle si ann de bē̃ nunner brunse, nõ griğe si der grạmp net. $(S n)$

When boys go swimming they should urinate down their own legs to prevent cramps.

1606. 'S wassser fun nein gekochte oier dreibt me mēdel ir kind a ab. $(B u)$

The water in which nine eggs were boiled will cause abortion.

1607. Mer soll schwōbe in en sak nēe un an der hals henke, granket a abzuha्alte. (Be,Lnc, $Y$; Heidelberg)

Sew roaches into a bag and suspend it from the neck to ward off disease.

1608. Ẽnich ebber as en maulwærf in der hand hēbt bis or dōd is grikts mittel net. (Be,Lnc, Na, Sc, Y; Heidelberg)

If you hold a mole in your hand till it is dead you will never have a felon.

1609. Wammern gewex' hot såkt mer dreimol in der ka' r:

wann der pærre der sēğe schprecht:

was ich å guk is en sind,

was ich schtreich, ferschwind. $(B e)$

If you have a tumor say three times in church while the benediction is pronounced:

What I look at is sin.

What I stroke, may it vanish. 
Wenn einer ein gewächs oder sonst was böses von warzen an sich hat, soll er in die kirche gehen, und wenn er zwei personen mit einander sprechen sieht, soll er das gewachs berühren und dreimal sprechen: was ich sehe, das is eine sünd, was ich greife, das verschwind. A M 1. 39

1610. Reib gift mit milich fun milich graut oder schēlgraut. (Bu,Lb,Lnc, Mt, Sc,Sn; Heidelberg)

For ivy poison use the milk of milkweed or celadine.

1611. Fer schnuppe, rích dreimōl in der schū. $(N u, Y)$

For coryza, sniff into a shoe thrice.

Fin weib, die den schnupfen hat, soll dreimal in des mannes schuh riechen.

1613. Fer schnuppe, får mit em finger zwische de zēe dæ'rich un rìch drå̃ . $(B e, C, L h, M r, N a, N u, S c$, $S n, Y$ )

For coryza, pass your finger between your toes and smell at it.

Für den schnupfen, wenn du deine schuhe und strümpfe ausziehst, so fahre mit dem finger durch alle zehen und rieche daran. Hoh 13

1614. Fer mutterwē får mit de finger daerich di zēe un rtch drå̃. $(D, L b, Y)$

For hysteria, pass your finger between your toes and smell at it.

1615. Blūt zu schtille: guk di wand schtærr å un blinsel net, un zēl hin'nerschich fun fuf'zich bis drei. (Be, $B u, L b, L h, M r, M t, S n, Y$ )

To stop hemorrhage; stare at the wall and count backwards from fifty to three.

Fange an von funfzig bis auf drei zurück zu zählen. Wenn du bis an drei kommst, dann bist du fertig und das blut ist gestillt. Hoh. 26 
1616. Mer kạnn mit me schmutziche deller brauche fer wēkschisser. $(B e, C)$

Powwow with a greasy plate for sty.

1617. Geilskeschte sin güt fer peils. (Lb,Lnc, Mt, Na, Sn, $Y$; Ettenheim)

Horsechestnuts are good for piles.

1618. Mer soll wolle bletter nō dråğe fer peils. $(B e, B u$, $L h, L n c, M r, M t$ )

For piles, earry mullein leaves on your person.

1619. Wammer peils hot soll mer sich uf wolle bletter hoke. (Mr, Na; Ettenheim)

Sit on mullein leaves to ease piles.

1620. Wạmmern maulwærf in der hand hēbt bis er dōd is grikt mers bēsding' net. ( $B u, C, L n c, M r, S c, S n)$ Hold a mole in your hand until it is dead and you will never have a felon.

1621. Wạmmern hạfe wū noch nix drin wår mit wạsser un'ichs bett schtellt leit sichs grank net uf. ( $\mathrm{Na}$; Freiburg)

A never-before-used crock filled with water and placed under the bed will prevent bedsores.

1622. Wạsser un'ichs bett gschtellt is gūt fer nạchtschwitze. $(D, S n ;$ Freiburg $)$

Set water under the bed to cure nightsweat.

1623. Mer soll drei grumbtre im sạk nōdråğe fer peils. $D, L h, N a)$

Keep three potatoes in your pocket as a cure for piles.

- 1624. Wạnnd der di zēe'neğl uf der Kærfrei'dåk schneitscht, waxxe si der ins lēte. $(Y)$

If you cut your toenails on Good Friday they will become ingrown. 
1625. Wămmer geblōkt' is mit ketǣ ${ }^{\prime}$ soll mer alle obed fun seim ēğne wąsser di nås nuf schnuppe sō ąs es in der hals kummt. Mer solls ẩer rausschpaue. (Be, Lh, Na; Neustadt)

To cure catarrh snuff your own urine at night, but spit it out.

Comment est bonne coutre le rheume l'urine des petits enfans? $V S L 2.2 .489$

1626. Wạmer grank is soll mer Sunndåks 's ērscht mōl ufschtẽ $\tilde{e}^{-}(B e)$

You should always get up from a sickbed for the first time on a Sunday.

1627. Wạmmer grank is soll mer Sunndåks net ufschtẽ fer uf bleibe schunscht hąppent ebbes. ( $A f$ )

Never get up out of a sickbed on Sunday for fear of dire consequences.

Wenn man am sonntag krank wird, muss man sterben. $W u 59$ 


\section{FRECKLES}

1628. Summerfleke zu ferdreibe soll mer si mit dåfwęsser wesche. (Af; Stuttgart)

Remove freckles by washing them with the water of baptism.

1629. Wănns uf em re'ğert wănn di sunn scheint grikt mer summerfleke. ( $B u, C, M r, M t)$

Rain falling on you while the sun is shining causes freckles.

Wenn es regnet, während die sonne scheint, und der regen auf die nase oder ins gesicht fällt, bekommet man "rossmucken" (sommersprossen). VAS1.196

1630. Wạnns uf em re'ğgert wạnn en re'ğebōğe schtēt grikt mer summerfleke. (Af)

If rains falls on you while there is a rainbow, you will get freckles.

1631. Wạmmer sich di summerfleke uf der ǣrscht Moi mit då wescht kạmmer sich si uf di ǣrm oder di bēschlăğe, no grikt mer si dært ht〜. (Af)

If you wash your freckles with dew on May 1, you can transfer them to you arms or legs by hitting those parts of your body.

Washing the face with dew gathered on the morning of the first of May kept it from becoming freckled. G Scot 151

1632. Der ērscht Moi soll mer gråd aus em bett nausgẽ $\tilde{e}^{-}$ un sich mit em då as uf wēze oder grås is wesche di summerfleke zu ferdreiøe, a schraue dū $\tilde{}$, sell is, mer dærf nix schwetze. (Af) Var. un wårze. $(B e, B u, C, D, M t, S c, Y)$

Rise early on the first of May and without dressing or speaking wash with dew collected on wheat or grass. The freckles will disappear.

.... and warts. 
Die sommersprossen vergehen, wenn man sich in monat Mai mit tau von roggen wäscht. VAS 1.486

Sich am 1. Mai mit morgentau waschen vertreibt sommersprossen. $W u 76$

1633. Wesch summerfleke mit wåsser ân uf me gråbschtēschtēt, nō gēn si wek. (Be,Lh)

Wash freckles with water collected on tombstones.

Mit regenwasser, das auf leichensteinen stehen bleibt, vertreibt man sommersprossen. $G 3.1025$

1634. Im Mærz wescht mer sich mit schtumpewassser summerfleke zu ferdreibe. ( $A f$; Heidelberg)

To destroy freckles wash them in March with water collected in the hollow of a stump. $\ldots$ and warts.

1635. Der ērscht Moi wescht mer di sunnefleke mit då. (Lnc, $N u$ )

Wash freckles with dew on the first of May.

Sich am 1. Mai mit morgentau waschen vertreibt die sommersprossen. $W u 76$

1636. Mærze då is gūt fer summerfleke. (Lnc, Na, $\mathrm{Y}$; Heidelberg)

March dews are good for freckles.

1637. Summerfleke fergē'ne wanmmer si reibt mit me frischgelēk'te Kærfreidåksoi uns nō unner der dạchdråft fergråbt. ( $B e, C, L n c, M r, S n ;$ Freiburg)

Freckles will disappear if rubbed with a freshly laid Good Friday egg. The egg should then be buried under the eaves.

1638. Wạns me kind ins gsicht re'ğert ebs en jōr a्lt is wærts rosch'tich un sum'merflekich. (Af; Heidelberg)

If rain strikes a child's face before it is a year old its complexion will become rusty and freckled. 


\section{TEETH}

1639. Wămmer di zēe ${ }^{-}$schtærrt mit holz wūs gewitter nei gschlăğe hot schtopts 's zå wē ạter di zẽ faule em raus. $(C, N u, S c)$

If teeth are picked with wood from a tree which was struck by lightning the toothache will cease but the teeth will decay.

1640. Wạmmer zå wẽ hot, soll mern schliber nemme fume båm wūs gewitter nei gschlăge hot un demit' im zå rumschtærre bis er blūt. $(A f)$

To cure toothache pick the tooth with a splinter from a tree which was struck by lightning.

Vom blitz abgerissene baumsplitter als zahnstocher benutzt stillen den zahnschmerz und schützen vor demselben. $B$. S. 33. 131.

1641. Sunndåks schneit mer di neğel ąb, zå wē zu ferhtte. $(B e)$

Cut your nails on Sunday to prevent toothache.

1642. Schneit der di neğel ąlle Freidåk ạb, nō grikscht ken zå พē. $(A f)$

Cutting the nails on Friday prevents toothache. $V S L 2$. 515

Man beschneide alle Freitage seine nägel an händen und füssen, und so wird man vor zahnweh bewahrt, oder verliert dasselbe, wenn man damit behaftet ist. $V A S 1$. 482

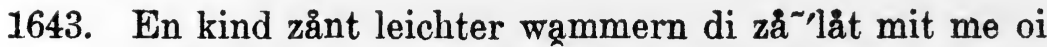
reibt, sell oi nō kocht uns dem kind ft'dert. (C, $L h$, Lnc, $M r, S n, Y$; Heidelberg)

A child will cut its teeth more easily if you rub its gums with an egg, then boil the egg and let the child eat it. 
1644. Sō ąs en kind net so hært zånt, henk en meisel an en bendel bis es dōd is, nō binn em kind seller bendel um der haln un loss en dært bis es en ferltrt. ( $L h$, $S n)$

To ease dentition in a child hang a mouse by a string until it is dead; then tie the string about the child's neck and leave it there until it loses it.

Wenn die eltern oder verwandten den kopf einer lebenden maus abbeissen und solches in ein leinenes eingenäht dem kinde anhängen ohne jedoch einen knopf in den faden oder das band zu machen, wird das zahngeschäft gut von statten gehen. $L V 126$

1645. Wann en kind zånt henkt mer drei meis ame bendel bis si dōd sin, nō henkt merm kind seller bendel $\mathfrak{a}^{\sim}$. (Lh, Lnc, Sc)

Put around the child's neck during dentition a string by which three mice had been hanged.

Das kind zahnt leichter, wenn die mutter oder der vater oder der pate drei lebendigen mäusen den kopf abreisst und unbeschrieen dem kinde anhängt, wobei aber kein knoten in das band gemacht werden darf. $W u 393$

1646. Wąnns kind åm zåne is reibt merm der gume mit em daume. $(\mathrm{D}, \mathrm{Mr}, \mathrm{Na})$

Rub the child's hard palate during dentition with your thumb.

Man reibe das zahnfleisch. Hlbg.

1647. Me kind reibt mer di zå ’’làt mit me oi, no lēkt mers wek. $(B e)$

In dentition rub a child's gums with an egg, and keep it. Zur förderung des zahnens oder überhaupt des gedeihens berührt man des kindes mund mit einem ei. $M S V 103$; $W u 392$

1648. Schmir me kind wū ąm zåne is der gume mit håsehærn $(L b, S c)$, a To aid dentition, rub a child's gums with rabbit's brain, before it is, however, six months old. 
Siede das hirn eines hasen und reibe den kindern das zahnfleisch damit, so wachsen die zähne ohne schmerzen. Ho $68 ; L \vee 126$

1649. Wạnn en kind hært zånt soll mer der kaffi wū mers brōt mit å wescht em kind zu drinke gebe. (Be)

Coffee with which bread is varnished should be given to the child to aid it in dentition.

Die warzen sollen vergehen, wenn sie mit bestohlenem streichwasser (zum überstreichen des brodes ehe es in den backofen kommet) wäscht. $L V 187$

1650. Mer grikt ken zå wē wămmer anl'lemōl âs mer sich wescht dreimol mit hend foll wasser hinne an de ōre hน ${ }^{\sim}$ fårt. $(B e)$

To prevent toothache you should, when washing your face, pass the hand full of water three times behind the ears.

Wenn man alltäglich mit frischem wasser mittelst des goldfingers hinter den ohren wäscht, wird man nicht von zahnweh befallen werden. $L V 233$

1651. Mer soll nix a abbeisse wū en rântt drå̃ gegnán'bert hot, schunscht faule em di zē aus. $(B e, C, D, L b, L h)$ Your teeth will decay if you eat anything at which rats have nibbled.

The same superstition is known in Hlbg. cf. Zfd $M$ 3. 316 Eating cheese or anything that has been nibbled at gives you sore throat. $V S L 2.152$

1652. 'S ērschtmōl a as en kind an en fremmer blătz kummt schmirt merm di zå låt mit fett fum flēsch brōde gråd aus der pạnn, nō zånts net hært. (Be,Lh)

To ease dentition, grease the child's gums with fat from the pan in which meat was fried. This should be done on the first visit of the child.

Gegen das herzgespann der kleinen kinder: man darf nur das fett vom braten aus einer bratpfanne nehmen, und zwar wenn man das andere fett ausgegossen hat: was also noch in der pfanne kleben bleibt, wird nur mit einem finger über den boden derselben heraus gestrichen und dem kinde die brust damit geschmiert. $A$ M 1.16 
1653. Di zē $\bar{e}^{-}$faule em raus wạmmer ąn ebbes kaut wū schun ebber schunscht drå gekaut hot. (Lnc; Heidelberg)

Your teeth will decay completely if you nibble at anything at which some one else has nibbled.

1654. Wạmmer alle mærğe der links schtrump 's ërscht åzìkt, grikt mer ken zå พē. $(C, L b, L h, N a, S n, Y)$ oder wēer hals. $(C)$

Put on the left stocking first and you will have no toothache, or sore throat.

If you always put your left stocking and shoe on first, it prevents toothache. In Sussex the right. V S L 2. 515

1655. En geroppter zå soll mer gråd in der ofe schteke. $(M r)$

An extracted tooth should be put into the fire at once. $V$ $S L 2.162$

Den ausgezogenen zahn soll man verbrennen. $B S 33.25$

1656. Fer zå wē: reib di ze $\overline{\mathrm{e}}^{\sim}$ mit re schlangehaut. (Lnc, $S n$ )

Rubbing the teeth with a snakeskin will cure toothache. The cast skyn of a serpent is medicinable. $V S L 2.1 .397$; $D$ Eng 157

1657. Zå พē zu ferdrei’øe, schtært mer der zå mit re nōdel wū mern dōde glēd mit gemacht hot. (S, Sc; Freiburg)

$\mathrm{Nu}$ )

Pick a tooth with a needle used in making a shroud to stop toothache.

1658. Wạmmer zå̃ wē hot, schtært mer ąm zå mit me nåğel aus re låd, ą̄er der zå fault nō raus. (Na, Picking a sore tooth with a coffinnail will stop toothache, but the tooth will decay.

1659. En nạğel aus re låd ime zå rum'gschtært ferdreibt zå พе̄. $\quad(B e, C, L b, L h, L n c, M r, M t, S c, S n, Y)$

To cure toothache, pick the tooth with a coffinnail.

Sargnägel heilen auch zahnschmerzen. $W u 135$ 
1660. Wạmmern schlạngehaut wũ di schlang frìjōrs rausgschluppt is mit de zẽ $\bar{e}^{-}$ufhēbt, un hin'nerschich låft, sō fíl schritt às mer hin'nerschich gèt, so fíl jōr hălt

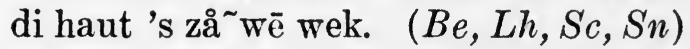

The number of steps you take backward while holding between your teeth the skin shed by a snake indicates the number of years you will not suffer toothache.

The cast skyn of a serpent is medicinable. $V S L 2.1 .397$

1661. Wạmern zå roppe losst soll mern mit hēm nemme un in en meisloch schmeisse, nō wærts net wē. ( $A f)$ To prevent sore gums after the extracting of a tooth, take the tooth home with you and throw it into a mouse hole. Wenn das kind die zähne wechselt, so muss man den ausgefallenen oder ausgezogenen zahn in ein mäuseloch stecken. B $S 33.116$

1662. Wạmmer ins feier schpaut grikt mer zå wē. (Lnc, Mr)

Spitting into fire causes toothache.

Wer ins fener spuckt, bekommt zahnweh. $\quad Z 308$

1663. Mer grikt ken zå wẽ wạmmer immer 's ērscht in der recht rokærmel schluppt. (Lb; Kaiserslautern)

To prevent toothache, always slip into the right coat sleeve first.

1664. En kind zånt leichter wammerm di zå låt reibt mit de rassle fun re rasselschlang. $(B e, L n c)$

A child will cut its teeth more easily if its gums are rubbed with the rattles of a rattlesnake.

1665. Wạnn en kind 's èrschtmol zum nạcht'mōl gange wår solls gråd wạnns hēm kummt in en âbbel beisse, nō grikts ken zå̃ ${ }^{2} \bar{e}$. (Be; Freiburg)

To prevent toothache a person should bite into an apple immediately upon coming home after his first communion.

1666. Fer zå wē beiss en weisser hunns'gnodl ạb. ( $D, L n c$; Lustnau)

To stop toothache bite off a white dog turd. 
1667. En kind zånt leichter wạmmern der kamm fume gschląchte håne dærichs maul zîkt eb der håne dōd is. $(D, L n c, Y)$

To ease dentition pass the comb of decapitated cock through the mouth of the child before the cock is fully dead.

Ein oft bewährtes mittel für schmerzloses zahnen der kinder. Man schneidet dem haushahn mit einer schere in den kamm und bestreicht mit dem hervorkommenden blut die "biller" einmal oder zweimal. $\operatorname{Dr} 213$

1668. Wạmmer der hærn'zå fun re sau nōdråkt grikt mer ken zå พē. $(A f ;$ Heidelberg $)$

Carry with you the braintooth [?Probably the lower maxillary] of a hog to prevent toothache.

1669. Wạmmer immer di hend a b'driklt færm gsicht grikt mer ken zå wē. $(L h)$

Wiping one's hands before the face prevents toothache.

Zahnschmerzen vergehen für immer, wenn man sich morgens nach dem waschen die hände zuerst abtrocknet. Z F V 1891. 193

1670. En kind zånt net so hært wạmmerm en håsezå å henkt. (Af; Heidelberg)

To aid dentition suspend a rabbit's tooth about the child's neck.

1671. Di finger un zēeneğel gråbt mer u'nich der dạchdrạp uf der winterseit ei ${ }^{\sim}$, nō grikt mer ken zå ${ }^{\sim}$, ( $\mathrm{Be}, \mathrm{C}, \mathrm{Lh}, \mathrm{Mr}, \mathrm{Na}$; Freiburg)

To prevent toothache bury the parings of fingernails and toenails under the eaves on the north side of the house.

1672. Wạnn en kind ạm zåne is zånts leichter wạmmerm en fischel dærichs maul zikt. ( $B e, C, D, L b, L h, M r$, $M t, N u, S n)$

Pass a small fish through the mouth of a teething child to ease its dentition.

... fischbein. Freiburg 
1673. Wạnn em en zå rausfąllt, schmeisst mern in en meisloch un såkt: meisel, meisel, ich geb dern a्रlter zå , geb mern neier defōro $\mathbf{r}^{\prime}$ ( $\left.A f\right)$

When a tooth drops out, throw it into a mouse hole and say: mousey, mousey, I am giving you an old tooth, give me a new one in its stead.

Wenn einem kinde ein zahn ausfällt, muss es denselben in ein mausloch werfen und sagen: maus, du hast einen alten zahn, bring mir bald einen neuen. $Z 61$ 


\section{WARTS}

1674. Mer mącht di wårz blūte, nō(d) reibt mern wårzicher ąbbel driber un fergråbt en unnerm dạchdrạp. (Bu, $\hat{L} b, L n c, M r, N a, S n, Y$ )

Scarify a wart and rub it with a warty apple. Bury the apple under the eaves and the wart will disappear.

Ritze die warz mit einem spitzigen instrument bis sie blutet; fange dieses blut mit einem geschälten apfel auf und gib es den säuen. Am besten tut man dieses beim abnehmenden mond. Ho 109 ; cf. $L V 186$

Sometimes an apple will be cut in slices and when all the warts have been rubbed, the slices will be buried. $B F$ 57

1675. Mer schneit en zwibel in zwē, reibt di wårz mit de schtiker fun der zwibel, schtekt si nō wider zănme un fergråbt si unner der dạchdråft. (Af)

Halve an onion, rub the wart with the halves, put the pieces together and bury them under the eaves.

Warzen vergehen, wenn man sie mit einer zerschnittenen roten hauszwiebel reibt. Ho $p 40 \mathrm{cf} . L V 186$

Rub warts with two halves of an apple cut in two; then tie the halves together. $V S L 2.517$

1676. Wårze reibt mer mit glēne schtē $\sim$ cher un schmeisst si nō in en gråb. (Be; Freiburg)

Rub warts with pebbles and throw them into a grave.

1677. Wårze reibt mer mit blüt fume gannz schwærze hinkel. (Be; Freiburg)

Rub warts with the blood of a chicken which has nothing but black feathers.

1678. Wămmern grot dōd'mạcht grikt mer wårze ąn di finger. (Be, Bu,Lb,Lnc, Mt,Sc,Sn,Y;Heidelberg)

If you kill a toad you will get warts on your fingers. 
WARTS.

1680. En wårz ạn re kū îrm eider hēsst mer âssche, nō gēêt si wek. $(B e)$

Call a wart on a cow's udder "ash" [?] and it will disappear.

1681. Di mi'lich fun schēlgraut ferdreibt wårze. ( $A f$; Heidelberg)

The milky juice of celandine (chelidonium maius) drives away warts.

The wart is to be anointed with the juice of some acrid plant. $F R 1.225$

1682. En wårz reibt mer mit me glēne schtē $\bar{e}^{-}$un schmeisst en no iber di links schulder, a a ber mer dærf nix schwetze, nō gēt si wek. $(B e, B u, D, L b, L h, M t, N u$, Sn, Y)

Rub a wart in silence with a pebble, throw it over the left shoulder and the wart will disappear.

Rub warts with pebbles; put one for each wart in a bag and throw it over the left shoulder. The person who picks up the bag gets the warts. $V S L 2.517$

If you rub your warts with a pebble, wrap the pebble in paper and throw it away. $C S A 907 ; D M 199 ; B F 41$

1683. En schtik grum'bìr uf en wårz geriøe un nō unich der dạchdråft gegråte soll wårze ferdreibe. (Af) Warts are said to disappear if rubbed with a piece of a potato which is then buried under the eaves.

Man bestreiche die warzen mit rohen kartoffeln und vergräbt sie dann in der dämmerung oder bei mondschein schweigend unter die dachtraufe. $W u 331$

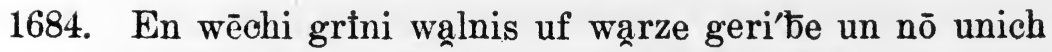
der dạchdrap gegrå5e nemmt wårze wek. (Be, $B u$, $C, D, L b, L n c, M t, N u, S c, Y$; Freiburg)

Remove warts by rubbing them with soft green walnuts. Bury the walnuts under the eaves.

1685. Reib en wårz mit re grtne wạlnis. (Sn) Rub a wart with a green walnut. 
1686. Wårze zu ferdreito muss mer di hand fume dōde driter schtreiche. $(B e, B u, C, D, L b, L h, M r, M t$, $N a, N u, S c, Y$ )

Warts will disappear if you rub them with the hand of a corpse.

Muttermale, warzen oder sonstige auswüchse kann man vertreiben, wenn man mit der hand einer leiche unter anrufung Gottes dreimal über kreuz darüber hinstreicht. B S 33.140

A dead man's hand is supposed to have the quality of dispelling humors. $F R 1.227$

1687. Wårze zu ferdreibe, reib si mit būne un gråb selli būne nō u'nich der da्ch'drạp. $(B e, B u, C, D, L h$, $M r, M t, N u, S c, S n, Y$ )

To get rid of warts, rub them with beans and bury the beans under the eaves.

As this beanshell rots away

So my warts shall soon decay. $F R 1.221$

1688. Mạch en schlitz in en būn un reib si itor di wårz. $(B e, C)$

Slit a bean and rub it over the wart.

1689. Dū $\sim$ mi'lich fun mi'lichgraut uf wårze. ( $B e, B u, L b$, $L h, L n c, N u, S c, S n, Y$ )

Put the milk of common milkweed (Osclepias Cornuti) on warts.

The wart is to be anointed with the milk or juice of some acrid plant. $F R 1.225 ; C \& A 894$

1690. Der kopp fume håne as mer juscht gschlacht hot soll mer uf en wårz reibe. $(B e, C, D, L b, L h, M r, N a$, Nu, Sn; Freiburg)

To remove a wart rub it with the head of a rooster that has just been killed; and then bury the head under the eaves. To remove warts: Take an eel and cut off the head. Rub the warts with the blood of the head. Then bury the head in the ground. When the head is rotten, the wart falls off. $H 66$ 
1691. Wạmmer zwē sēnt reite uf me gaul såkt mer : Fedder ritter, hinner ritter!

Nemm mei ${ }^{\sim}$ wårze mit der! $(B e, L b, L h, M t, S c, Y)$

When you see two person riding on one horse, say: Forward rider, rear rider, take my warts with you.

Zwei reiter auf einem pferd,

Der hintere ist meine warze wert. $Z f D M 2.102$

In Kent, if a man wets his forefinger with saliva and rubs the wart he wishes to get rid of three times in the same direction as a passing funeral, saying each time, "My wart goes with you", a cure will soon follow. $B \quad F 43$

1692. Reib en wårz mit re schpek'schwårt un henk di schpek'schwårt nō ann en ạbbelbåm, so ạs di feğel si fresse. $(L h)$

Rub a wart with the rind of bacon and hang it on an apple tree so that the birds may eat it.

Gegen warzen: man bestreicht sie mit einem stück speck und hängt dieses an einen baum; sobald der speck vertrocknet, schwinden auch die warzen. $W u 338$

In Cheshire, steal a piece of bacon and rub the warts with it, then cut a slit in the bark of an ash tree and slip the bacon under a piece of the bark. $B F 38$

1693. Reib en wårz mit re welschkankærn un fergråb si unich der dạchdrap. $(B e, L n c)$

Rub a wart with a grain of corn and bury it under the eaves.

Will man warzen vertreiben, so umziehe man jede dreimal mit der spitze eines gerstenkornes und setze dieses in die erde. $Z 199$

A Scotch version bids the sufferer wrap up in a parcel as many grains of barley as there are warts and lay the parcel on the public road. Whoever finds and opens it receives the warts. $B \quad F 42$

1694. Mạch en wårz blūte mit me năğel aus re låd, nō gēt si wek. (Be, D, Lnc, Sc; Freiburg)

Scratch a wart with a nail taken from a coffin until the wart bleeds and it will disappear. 
1695. Reib en schpillumbe iநer wårze un gråt en nō unich der dąchdrapp. (Be,Lb,Lnc, Sc,Sn,Y)

Rub warts with a dishcloth and bury it under the eaves. Man reibt warzen mit einem alten lumpen aus einem fremden hause und scharrt ihn dann in die erde. $L V 186$

1696. Wårze zu ferdreibe muss mer si mit me gschtōlne schpillumbe reite. $(B e, C, D, L b, L n c, M r, N a, N u$, $S c, S n, Y$ )

To get rid of warts rub them with a stolen dishcloth. Man reibt warzen mit einem alten lumpen aus einem fremden hause und scharrt ihn dann in die erde. $L V 186$

1697. Wårze soll mer mit būne reibe un nō in der bąkofe schmeisse un færtschpringe ans mer si net hērt fergrache. $(D, L h, N u)$

Rub warts with beans, then throw the beans into the bakeroom, running away so as not to hear them burst.

In den glühenden backofen muss man so viele erbsen werfen, als man warzen hat, sogleich aber wegspringen, dass man's nicht "pratzeln" hört, sonst wird's schlimmer. $V A S 1.484$

1698. Uf der A Ab'dạnsdåk reibt mer wårze, grēn'åğe un so dergleiche. (Be, C, Lb, Lh, Mt, Sc,Sn,Y)

Rub corns, warts, etc., on Abdon's day (July 29 or 30 ).

Am Abdonsdag sticht man dreimal mit einer nadel in warzen, wehen, hühneraugen und dergl., um sie zu vertreiben. $B S 33.123$

1699. Reib wårze mit em wesch'lumbe wū en dōdes gewesche is wærre mit un fergråb en nō unich der dạchdråf. $\quad(L b, L n c, S n, Y)$

Rub warts with the washrag with which a corpse was washed and then bury the rag under the eaves.

Das tuch, mit dem dem sterbenden der schweiss abgetrocknet wurde, wird aufbewahrt, denn man kann mit ihm leicht wunden heilen. $R A 225$ 
1700. Wårze kąmmer ferdreibe wănmer si mærğets mit schpautz nąss macht eb mer ebbes gesse hot. (Be, $B u, D, L b, L n c, S n, Y$; Lustnau)

To drive away warts, wet them in the morning with fasting spittle.

Rubbing warts night and morning with fasting spittle will remove them. $B$ F 184

1701. Mer soll en kânt in en schtik hols schneide fer all di wårze as mer hot, nō sel schtik hols driber reibe un nō in der grund gråte. Wannns hols ferfault is gēn di wårze wek. $(B e, B u, C, D, L b, L h, M r, M t, N a$, $N u, S c, Y)$

Cut as many notches in a piece of wood as you have warts, rub them with the notched wood and bury it. When the wood has decayed the warts will disappear.

Man nimmt ein stückchen holz, schneidet so viel "krappen" hinein als man leichdornen hat und wirft es am Sonntag in den klingebeutel. $Z f D M 1.199$

Take an elderstick, cutting a notch in it for each wart and then burying it to rot in muck. $V S L 2.517 ; C S A$ 923

1702. Wårze muss mer mitre gschtōlne schpekschwårt reibe, no gēn si wek. $(A f)$

Rub warts with a stolen piece of rind of bacon.

Rub warts with a piece of stolen beef and bury it in the garden. Corn 148

1703. En wårz kạmmer mit re hōr ånbinne. (Af; Heidelberg)

Get rid of warts by tying them with a hair.

Tying a horsehair around each wart is considered efficacious.

D Y 166

1704. En wårz kạmmer mit me seidne fådem a abbinne. ( $D$, $\mathrm{Lb}, \mathrm{Mt}, \mathrm{Na}, \mathrm{Sc}, \mathrm{Y}$; Heidelberg)

Get rid of a wart by tying it with a silken thread.

1705. Bē en grautblått bis es wēch is, reibs i'நern wårz un gebs nō me gaul oder re kū zu fresse. (Be,Lb,Y) 
To remove a wart, rub it with a cabbage that has been toasted until it is soft and then feed it to a horse or cow.

1706. Mer soll rosei'nekærne uf wårze binne. (Bu; Heidelberg)

Tie raisinseeds on warts.

1707. Wårze soll mer $æ^{\prime}$ rik reibe mit hinkelfìs. $(C)$

Rub a wart thoroughly with chicken feet.

1708. Wạmmern wårz wescht mit wasser ąs uf me kìdrek schtēt, noch me reğe, gēt si wek. $(C, L n c, N u)$

Wash a wart with water collected on cattle droppings.

Warzen vertreibt man mit regenwasser, das auf kuhfladen liegt. $\quad Z 202$

1709. Mer soll en wårz mit der schū'sōl reit̄e. (C, Lnc, $M r, M t, N a, S c, S n$; Kaiserslautern)

Rub a wart with the sole of your shoe.

1710. 'S sălz wū mern wårz mit reibt soll mer nō in der bąk'ofe schmeisse. (Bu; Heidelberg)

Rub a wart with salt which is then thrown into a bakeoven.

1711. Reib en wårz mit re hek fume a a b’belbåm un blūk si nō unner. $(N u)$

Rub a wart with a dead apple twig and plough it under.

1712. Wămmer drei mōl mit em rechte fūss i’oern wårz reibt, gēt si wek. ( $N a, S n$; Lustnau)

Pass the right foot three times over a wart and the wart will disappear.

1713. Reib en wårz mit me gfunn'ne gnoche un lēk en nō gråd wider hĩ wì er gele'ğe hot. (Lnc)

If you find an old bone, rub the wart with it and lay it down exactly as you found it. $C S A 887$

Warzen vertreibt mann, wenn man sie mit einem gefundenen knochen bestreicht. $W u 341$

1714. Wạnn ēns ăs sei fạder nt net gsēne hot en wårz mit schpautz nasss mạcht gēt si wek. $(B e, D, L b, L h$; Lnc, $M t, S c, Y$ )

The spittle of a posthumous person removes warts. 
1715. En wårz ăme gaul hēsst mer assche, nō gēt si wek. (Be; Ettenheim)

If you call a wart on a horse "asche" it will disappear.

1716. En wårz ạme gaul seinre nås schmirt mer mit fett aus re fett'amschel. (Sc; Ettenheim)

Grease a wart on the nose of a horse with tallow from an old-fashioned tallowdip.

1717. En wårz ân re kū hēsst mer schtof'fel, nō gēt si wek. ( $Y$; Ettenheim)

Say "blockhead" [probably the German stoffel] to a wart on a cow and the wart will disappear.

1718. Wạnn en gaul en wårz hot, såkt mer hus'tschąk, nō gēt si wek. (Be,Lh; Ettenheim)

Say "sick em, jack" [?] to a wart on a horse and it will disappear.

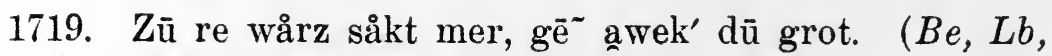
Lh, Lnc, $\mathrm{Mr}, \mathrm{Na}$, Sn; Lustnau)

To remove a wart, say: "Toad, get out!"

1720. Di ērscht grot as mer frìjōrs finnt soll mer uf em sei wårze reibe bis si dōd is, nō gēn di wårze wek. (Be, D, Lb, Lh, Sc; Freiburg)

Take the first toad which you find in spring and rub it on warts until it dies. This will cure warts.

1721. Uf der ērscht, zwet un dritt Moi wescht mer di wårze mit då un schląkt sich si hĩ wū mer si ht hăbe will. $(D, L n c, N u, S c)$

Wash warts with dew on the first three mornings in May, and with the hands hit the part of the body where you want the warts.

...... und man greift hinten an. Hlbg.

1722. Reib di wårz mit re schpekschwårt im ąb'nemmede un fergråb si unner der da्रchdrạp. (Af)

Rub the warts with the rind of bacon in the decrease of the moon and bury it under the eaves. 
1723. Reib en wårz mit re schpekschwårt un fergråb si u'nich der dąchdrąp. ( $A f)$

Rub a wart with the rind of bacon and bury it under the eaves.

Andere nehmen speckschwarten, wischen sie über die leichdornen, und werfen sie bei einem begräbnisse, nachdem sie ein vaterunser gebetet, ins grab. Zf $D M M 1.199$

Rub warts with the fat side of a piece of bacon with the rind on. $\quad C P \& P 535$

1724. Wesch wårze mit schtum'bewassser. (Af)

Wash warts with water standing in the hollow of stumps.

Warzen vertreibt man durch regenwasser, welches sich auf einem eichenstumpf gesammelt hat. $W u 244$

1725. Wårze reibt mer mit me sent un gråbt en nõ u'nich der da्ch'drạp. (Af)

Rub warts with a cent and bury it under the eaves.

Das ist gut für krampfadern. Freiburg

1726. Ferkåf di wårze fern sent un lēk der sent nō wek ås er net gejūsd' wært. (Af)

Sell your warts for a cent and put the money away so that it will not be used.

1727. Mer kåft wårze a ab mit me sent un schmeisst der sent nō wek. (Af)

Sell your warts for a cent and then throw it away.

1728. Wårze kammer ferdreibe mit brauche. Mer såkt drei ōted hen'drañ : Nei'mūnd, wạs ich å̃ guk, nemm zū; wạs ich schtreich, nemm âb. (Af)

Warts may be removed by saying the following powwowing formula on three successive evenings: New moon, what I behold, may it increase, what I stroke, may it decrease. Wenn der mond im wachsen ist, dann stellt man sich abends oder nachts an das offne fenster, schaut fest in den mond, indess man die warze mit dem zeigefinger berührt und leise reibt, dabei muss man dreimal sprechen : "was ich sehe, wachse, was ich fühle, nehme ab." Dieses dreimal getan und die warze fällt mit dem abnehmenden mond ab. Zf $D M 2.101$ 
1729. Wạmmer grote å rēkt grikt mer wårze. (Af; Kaiserslautern)

Touching a toad will cause warts to appear. $\quad C S A 882$

1730. Wạnn em en grot ferpisst grikt mer wårze. (Af; Freiburg)

Toad urine causes warts.

1731. Schtēl en schtik kạ́lik un reibs uf en wårz. (Mr; Heidelberg)

Steal a piece of lime and rub it on a wart.

1732. Wạnn en kū en wårz ạm eider hot hēsst mer si

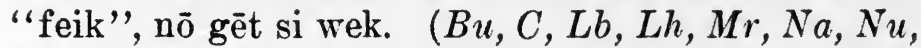
Sc; Lustnau)

Call a wart on a cow's udder "fig" and it will disappear. [cf. Muret-Sanders, Deutsches Wörterbuch sub Feige.]

1734. Wạmer wasser nemmt fer gschærr wesche wū oier drin gekocht wåre grikt mer wårze an di hend. $(B e$, $C, L b, L h, L n c, M r, N u, S c, S n, Y)$

To wash dishes in water in which eggs have been boiled is a sure way to have warts.

In dem wasser, in dem eier gekocht wurden, darf man sich die hände nicht waschen, sonst bekommt man warzen an die hände. $A A 9$

Washing the hands in water in which eggs have been boiled causes warts to grow. $E Y 46$

1735. Wạmmer ebber di wårze zēlt wært er si lōs a ăber mer grikt si selbert. $(A f)$

If anyone counts your warts you will get rid of them but the person counting them will get them.

Wenn man die warzen von einem andern zählen lässt, so wird man davon befreit und der zähler bekommt sie. $Z$ $200 ; B S 33.140 ; V A S 1.483 ; C S A 874 ; V S L$ 2. 518

1736. Mer nemmt en bendel un macht en gnopp nei fer jēder wårz; nō wămmer mēnt mer het si alll, zēlt mer di gnepp un di wårze. Wạmmer ąber net gnepp 
gemacht hot fer ânll di wårze, gēn juscht di ewek' wū mer gnepp defōr gemacht hot. Nō gråbt mer seller bendel u'nich der dạchdrạps. (Be,Lh, Lnc, $N a, S c$, $S n, Y)$

Tie knots into a string, one for each wart. A wart will disappear for each of the knots originally tied. Bury the string under the eaves.

Mach an einen faden so viele knöpfe, als du warzen hast, und wirf ihn hinter dich oder vergrab ihn im miste oder unter einer dachrinne, und die warzen fallen $a b$, so bald er fault. $Z 198 ; G 3.785$

A piece of string to be tied in knots, one for each wart, touching them successively with their respective knots and then burning the string. $V S L 2.517$

1737. Der weschlumbe wū en dōdes gewesche is wærre mit reibt mer uf wårze un fergråbt en nō u'nich der dạchdråf. $\quad(L b, L n c, S n, Y)$

Rub the washrag used in washing a corpse over warts and bury it under the eaves.

1738. Reib en wårz mit re rōe grum'bìr. ( $B e, B u, C, L n c$, $M r, M t, N u, S c, Y$ )

Rub a wart with a raw potato.

Man bestreiche warzen mit rohen kartoffeln. $W u 331$ 


\section{RHEUMATISM}

1739. Mer soll der hærnzå fun re sau å henke fer ru'medis. $B e, L b, L n c, M r, N u, S n)$

For rheumatism, wear the eyetooth of a pig.

Der zahn des ebers ist bild des blitzes und schützt gegen zahnweh. $\quad W u 97$

1740. Mer soll drei grumbtre im ho'sesak nōdråğe fer ru'medis. ( $B e, B u, L b, L h, M r, N u, S n$ )

As a prevention or cure for rheumatism carry three potatoes in your pants pocket.

1741. Wạmmer der drei'ekich gnoche ime hinnerschunke im sakk nōdråkt grikt mer ken ru'medis. (Be,Bu, $D, L h, S c)$

To prevent rheumatism carry in your pocket the triangular bone from a ham.

Vor rheumatismus bleibt man bewahrt, wenn man von dem kugelgelenk eines schinkenbeines die obere hälfte abschneidet, dasselbe durchsticht und mit einem bindfaden das schlüsselbund bindet und mit demselben stets in der tasche trägt. Schon vorhandenes rheuma vergeht dadurch allmählich. $A A 91$

1742. Wạmmer di ru'medis hot soll mern kup'perner sent in di schū dĩ $\tilde{u} . \quad(M r, S c)$

To cure rheumatism, put a copper cent into your shoe.

1743. Mer dråkt en schtik elektri'siti im sạk nō, nō grikt mer ken ru'medis oder wạmmer si hot wært mer si lōs. (Be, C, Lnc, Mr)

Carry a piece of electricity [a piece of burnt-out carbon from an arc light] as a prevention or cure for rheumatism.

1744. Mer soll en bens nōdråğe fer ru'medis. (Be, Lnc, $M r, M t, N a, S c, S n, Y$ )

Carry a penny on your person to cure rheumatism. 
1745. En hüfnăğelring is güt fer ru'medis. $(B e, C, D, N u$, $S c, Y)$

A ring made of a horseshoe nail is good for rheumatism.

1746. Dråk en messner ring fer ru'medis. (Be, Lnc, Mt, $S c)$

Wear a brass ring to cure rheumatism.

1747. Glåsne kepp u'nich di bettschtolle gemacht solle ru'medis ferhite. (D, Lh, Lnc; Kaiserslautern)

To prevent rheumatism, put glass knobs under the bed posts.

1748. En gidærr'ti ōlehaut um en gnechel gebunne kjūrt ru'medis un halt si å wek. (Af; Freiburg)

A dried eelskin tied about a joint cures and prevents rheumatism.

1749. Lērs wassser wūd di fís ōbeds drin gewesche hoscht net bis de nēkschte dåk aus, oder du grikscht di ru'mądis. $(L b)$

Do not throw out the water in which you washed your feet in the evening until the next day, for fear of rheumatism. Ein gebrauchtes fussbad soll nicht eher als den andern tag ausgegossen werden, man giesst sonst das glück mit weg. G 3. 350

1750. S wansser wū mer sei ${ }^{\sim}$ fìs ōbeds gewe'sche hot soll mer numme jō auslēre, schunscht grikt mer di ru'medis. (Be, Lh, Lnc, Sc, Y)

By all means throw out the water in which you have washed your feet to prevent rheumatism.

Water that has been used to bathe the feet must be put outside the door at night for fear of fairies. F B 4. 351

1751. Du grikscht ken ru'medis wạnnd en nạğel fun re låd nōdråkscht. ( $C, N u, S c, S n, Y)$

Carry a coffin nail to prevent rheumatism.

For cramp, wear coffin rings dug out of a grave. $V S L 2$.

2. 492 
1752. Fer ru'medis mạch en ring aus me năğel fume hüfeise wū di neğel noch drin sin un wēr der ring. $(B e, C, D, N u, S n, Y)$

If you find a horseshoe containing eight nails, have a ring made of one of these nails and wear it to cure rheumatism.

Man macht auch krampfringe aus hufeisen. $W u 130$

1753. En gsalzner mą'kerel uf di fîs gebunne is gūt fer ru'medis. (Lnc, $Y)$

A salted mackerel tied on the feet cures rheumatism.

A raw salt herring with the bone taken out applied to the neck, tying a handkerchief over it and keeping it on all night, cures sore throat. $\quad V S L 2.512$

1754. Fer ru'medis, dråk grum'bìre im sạk nō. $(B e, B u$, $L b, L h, M r, M t, N a, S n)$

Carry potatoes in your pocket as a prevention against rheumatism.

Gegen gicht, worunter ausser der eigentlichen gicht noch viele in gliederreissen oder lähmung sich bekundenden krankheiten verstanden werden: Man trägt drei gebettelte kartoffeln auf dem blossen leibe, bis sie verwelkt sind. $W u 356$

For rheumatism earry a raw potato or the piece of one. $V S L 2.509$

1755. Fer rumetis soll mer en geilskescht im sạk nō dråğe. $(A f)$

Carry a horse chestnut in your pocket for rheumatism.

Um gicht und rheumatismus zu heilen oder zu verhüten, muss man eine ungerade zahl rosskastanien bei sich tragen. $W u 356$

For rheumatism carry a horse chestnut. V S L 2.509 


\section{CROUP}

1756. Mess en kind mit me schtik holler un lēk 's nō ht ${ }^{\sim}$ wĩ ken sunn un ken mūnd ane scheint, nō grikts der schtikfluss net wanns mol lenger gewaxe is as der schteke. (Be; Freiburg)

Measure a child with an elderberry wand and put it where the rays of neither sun or moon strike it. The child will not have croup after it has grown taller than the wand.

1757. Mer muss en kind wū der schtikfluss hot ufs milz schtelle fume schtik ft as mer juscht gschlacht hot un druf bleibe losse bis 's milz kalt is. $(B e)$

To cure croup, the sufferer should stand on the warm spleen of a freshly slaughtered steer and remain standing on it until the spleen is cold.

1758. En hēm'gschpunn'ner woll'icher fåde um der hạls kenkt kjūrt schtikfluss. (Be, Lb, Lnc, $\mathrm{Mr}, \mathrm{Mt}, \mathrm{N} a$, $N u, S c, S n, Y$ )

A homespun woolen thread tied about the neck will cure croup.

Ein wollener strumpf. Freiburg

1759. En kind as der schtikfluss hot schtellt mer an en èchebåm, schląkt en nạğel $o^{\prime}$ நich em kind seim kopp in der båm so a as fum kind seine hōr dezü' kumme. Sell schtopt en. ( $(\mathrm{Lnc})$

A child suffering from croup can be cured if you place it against an oak tree and drive a nail into the tree above the child's head in such a manner that some of the child's hair is included.

Certain oak trees in Birkhampstead in Hertfordshire were long famous for the cure of ague. A lock of hair was pegged into an oak and then, by a sudden wrench, transferred from the head of the patient to the tree. $B F 39$ 
1760. Mer nemmt en kind as der schtikfluss hot, schtellts an en ēchebåm un schląkt en nąğel o'bich em kopp in der båm. Wanns kind dært driber naus gewąxe is grikts ken schtik'fluss $\mathrm{me}^{-}$. $(B e, B u, C, L b, L h$. Lnc, $N a, N u, S n$ )

Place a child suffering with croup against an oak tree and drive a nail into the tree directly above the child's head. The child will not have croup after it has grown taller than the mark in the tree.

Man stellt es an einen zwetschgen baum. Kaiserslautern

1761. Wannn en kind der schtik'fluss hot soll der peter en năgel o $o^{\prime}$ bich em kind seim kopp in en båm schlăğe. Wanns mol dært driber naus gewaxxe is grikts der schtikfluss nimmi. (Af; Freiburg)

To cure a child of croup the godfather of the child should stand it upright against a tree, and drive a nail into the tree above the child's head. The croup will disappear as soon as the child has outgrown this mark.

1762. Dũ $\sim$ hōr fume kind as schtikfluss hot in en loch ąs de in di wand gebōrt hoscht, zạpp sell loch nō zū uns kind grikt der schtikfluss nimmi. (Lnc)

Put some hair of a child that has croup into a hole bored in the wall, plug up the hole, and the croup will be cured. 


\section{CONVULSIONS}

1763. Wạnn en kind di gichtrē hot lëkt merm en gfunne hūfeise as en gaul sich nun'nergerisse hot un wũ all di neğel noch drin sin unichs koppekissi. ( $B e, L b$, $L h, M t, N a, N u, S c, S n, Y$; Freiburg)

To cure a child of convulsions lay under its pillow a horseshoe containing the regulation number of horseshoe nails and which was cast by a horse.

1764. Wạmmern hūfeise finnt wũ all di neğel noch drin sin soll mer selli neğel me kind a henke, no grikts ken gichtre. ( $\mathrm{Be}, \mathrm{Lb}, \mathrm{Lh}, \mathrm{Mt}, \mathrm{Na}, \mathrm{Y})$

If you find a horseshoe with seven (or eight) nails in it, suspend those nails from the neck of the child as a preventive against convulsions.

Kranke kinder heilt man, indem man ihnen ein gefundenes noch mit den nägeln versehenes, aber nicht mit der hand berührtes hufeisen auflegt. $W u 360$

1765. Wạnn en kind gichtrē hot dekt mers mit seim fạder seim hochzichrok zū. $\quad(N u)$

When a child has convulsions cover it with its father's wedding coat.

So oft die mutter ans der wochenstube geht, lege sie etwas von des vaters kleidern auf das kind, so kann es nicht ausgewechselt werden. $G 3.744$

1766. Gårn a as nt net nass wår un fume kind unner sibe jōr alt gschpunne is gūt fer gichtre wammers å henkt un henke losst bis en fun selbert a bafallt. (Be, Bu, $L b, L h, L n c, M r, M t, S c, S n, Y)$

Yarn that has never been wet and was spun by a child less than seven years of age will cure convulsions, if worn round the neck until it falls off.

Wer ein hemd an trägt, von garn gewoben, das ein mädchen unter sieben jahren gesponnen, der hat glück darin. $G$ 3. 115; of. Hoh $p 53 ; L V 124$ 
1767. Wannns ērscht hemm a gs mer me kind ådut noch net gewesche wår grikts kind di gichtre net. (Bu; Heidelberg)

A child will not have convulsions if the first chemise worn by the child had never been washed.

1768. Di ērscht schlōs ăs mer sēnt nochdem' as en kind uf di welt kummt soll merm kind fïdre, nō grikts ken gichtre. (Be, Sc; Lustnau)

A child will not have convulsions if it eats the first hailstone seen after its birth.

1769. Der åğe zå̃ fun re sau å kenkt schtoppt gichtre. (Be, D, Lnc, Mr, Sn; Heidelberg)

Suspend the eyetooth [?] of a pig from a child's neck to cure convulsions.

1770. Dåfwăsser schitt mer i'Đern gichtrōse schtok, nō grikt sell kind ken gichtre. (Be,Lh, Lnc, Sn, $Y$ : Heidelberg)

The water used in baptizing a child should be poured over a peony bush to prevent convulsions in the child.

1771. Fer gichtre lēkt merm kind en gfunne hūfeise wū all di neğel noch drin sin u'nich der kopp. (Af) Cure convulsions in a child by laying under its head a found horseshoe containing eight nails.

Dem kind ein hufeisen unter den kopf gelegt ist ein gut mittel für gichter. $M S V 117$

1772. Wann en kind gichtre hot henkt merm en schtik schtrik wū ebber sich kenkt hot mit uf di bruscht. (Be, Bu, C, D, Lb, Lh, Lnc, Nu, Sc, Sn, Y)

To stop convulsions in a child, lay on its chest a piece of. the rope with which some one has committed suicide. Der strick des gehenkten gilt als glücksmittel. $B M 21$

1773. Wann kinner gichtre hen soll mer si net å rēğe, 's dut ne sō wē. $(B u, L h, M r, N a)$

Do not touch children in convulsion, it increases their suffering. 
Hat ein kind die gichter, so darf man seine glieder nicht berühren, da sie sonst lahm werden. Alem 19. 166

1774. En kind as gichtre hot dekt mer mit seim facder seim rok zū. $(N u)$

Cover a child suffering with convulsions with its father's coat.

So oft die mutter aus der wochenstube geht, lege sie etwas von des vaters kleidern auf das kind, so kann es nicht ausgewechselt werden. $G 3.744$.

The father's shirt wrapped round the newborn babe was esteemed a preservative against the child being stolen by the fairies. $S H S 37$

1775. Hēb me kind sei ną̧øelschnūr uf, dri'kel si un lēk si wēk. Wannns kind gichtre grikt, nemm di nąbelschnūr, mach si fei ${ }^{-}, \mathrm{rtr}$ si in brei un ftder em kind der brei. Sell ferdreibt di gichtre. ( $L b, L h, L n c$, $Y$ )

Take the child's umbilical cord, dry it and preserve it. When the child is seized with convulsions, pulverize it, mix it with pap and feed the child with it. This will cure convulsions.

Die abgefallene nabelschnur dem kinde in brei eingegeben, macht dieses gelehrt, bewahrt vor fallsucht oder vor gichtern. $\quad B M 17$

1776. Me kind as gichtre hot lēkt mer fun de el'dre tre hochzichglēder u'nich der kopp. ( $A f)$

A part of the parents' bridal trousseau placed under the child's head will stop convulsions.

Gegen gichter legt die mutter dem kinde ihre seidne brautschürze unter das köpfehen. $L V 125$

1777. Schtell en kind as gichtre hot an di wand, bör en loch in en bōrd in der wand, dū fum kind seine hōr nei un zapps loch zū. No grikts ken gichtre $\bar{e}^{-}$. $(L b)$ Bore a hole into a board in the wall, put into it some of the hair of a child suffering from convulsions, then plug up the hole. This will cure convulsions. 
1778. Wạmmern lumbe ibern gichtrōseblum binnt un nō '. kind mit sellem lumbe wescht, grikts di gichtre net. (Be, Lnc, Mt ; Heidelberg)

To prevent convulsions wash the child with a rag that had been tied over a peony flower.

Peony doth help epilepsies. $\quad C P \& P 173$

During teething wear a necklace of beads turned from the root of the peony. $V S L 2.514$

1779. Me kind sals in di hend un zwible uf di fis gebunne schtopt gichtre. $(B e, B u, C, D, L b, L n c, M t, Y$; Heidelberg)

Salt put in the hands and onions tied to the feet of the sufferer will cure convulsions.

When a child has convulsions rub its hands with a raw onion. $C F Y 170$

1780. Fer gichtre binn em kind zwitle uf di fts. (Bu, Mt. $S c$ )

To eure convulsions, tie onions to the child's feet.

When a child has convulsions rub its hands with a raw onion. $C F Y 2.170$ 


\section{WHOOPING COUGH}

1781. Fer blō hūsch'te, dū̃ nein wærm in en bottel un ferschtekl si. (Lnc)

To cure whooping cough, put nine worms into a bottle and hide it.

1782. Di belle fun re rạsselschlạng å kenkt kjūrt der blō hūsch'te. $(M t)$

Wear the rattles of a rattlesnake to cure whooping cough.

1783. Kạtzesupp is gūt fer blō hūsch'te. (D)

Cat soup is good for whooping cough.

Katzenfleisch ist gut gegen schwindsucht. $W u 127$

1784. Dåfwassser is gūt fer blō hūsch'te. $(D)$

Water of baptism is good for whooping cough.

Das taufwasser wirkt heilend bei kinderkrankheiten. $W u$ 139

1785. En kel'lerēsel ime sạk um der hạls kenkt is güt fer blō hūsch'te. $(Y)$

A wood louse suspended from the neck in a bag is good for whooping cough.

1786. Tẽ fun blōe glēblume is gūt fer der blō hūsch'te. (Be, $L b, L n c, S c, S n, Y)$

Tea made of blue clover blossoms is good for whooping cough.

Tee von schlüsselblumen... Fr

1787. Dråk rìme fun sei'leder nō fer blō hūsch'te. (Be, $D$, Lnc, Sn, Y)

Wear strips of leather made of pigskin to cure whooping cough.

1788. Schtēl mi'lich fer blō hūsch'te. (Lnc)

Drink stolen milk, to cure whooping cough. 
1789. Mer soll nạchts esse schtēle fær blō hūsch'te. (Be, $\mathrm{Bu}, \mathrm{Mt}$; Heidelberg)

Eatables stolen at night cure whooping cough.

1790. Fer blō hūschte schtēlt mer blō band un binnts an sich. (Be, Lb, Lnc, Mr, Mt, Sc, Sn, Y)

To cure whooping cough, steal a piece of blue ribbon and wear it.

Gegen halsweh hilft, wenn man ein blaues schnürlein um den hals bindet. $Z 187$

1791. Wănn en kind ås der blō hūsch'te hot en nìğer bosst gèt em sei blō hūsch'te wek. (Be,Bu,Lb,Lnc, Mr, $M t, N u, S c, S n, Y)$

Kissing a negro will cure a child of whooping cough.

1792. Wann en kind en níğer bosst ebs en jör alt is grikts der blō hūsch'te net. (Be,Bu,Lb,Lnc, Mt, Nu)

If a child kisses a negro before it is a year old it will never get the whooping cough.

1793. Wann ēns der blō hūsch'te hot binnt mern schpinn in en fingerhūt un henkts îm $\mathfrak{a}^{\sim}$. $(N u)$

Tie a spider into a thimble and suspend it from the neck of the person with the whooping cough.

1794. Mer kåft rōt band im schtōr å̄er mer bezålts net: nō binnt mers um en fingerhūt wūn schpinn drin is un henkts me kind å $\sim$ as der blo hūsch'te hot. ( $L b$, Lnc, $M r, Y$ )

Go to the store and get a piece of red ribbon, without however paying for it, tie it around a thimble in which there is a spider and suspend it from the neck of a child suffering with whooping cough.

In Berlin geht man in neuester zeit, um heiserkeit, bösen hals, kehlkopfkrankheit und dgl. zu heilen, in einen posamentierladen unter den Linden und fordert ein stückchen floret band, man erhält ein solches schweigend, bezahlt nichts, und dankt auch nicht-es soll ein vermächtnis sein-und macht sich oder einem andern das bändchen um den hals, worauf die schmerzen verschwinden; wenn man bezahlt oder dankt, so wirkt es nicht. $W u 132$ 
1795. Mæ're milich is gūt fer der blō hūsch'te. (Af) Mare's milk is good for whooping cough.

1796. Di haut wū en schlang frìjōrs rausschluppt soll mer fei ${ }^{\sim}$ schneide umme kind fìdre âs der blō hūsch'te hot. $(L n c)$

Cut up and feed to the child the cast off skin of a snake to cure it of whooping cough.

1797. Fer blō hūsch'te, mer soll aus me blōe tombler drinke as mer gschtōle hot. (Lb, Lnc, Mr, Sc)

To cure whooping cough drink from a stolen blue tumbler.

1798. Wạnn ēns der blō hūsch'te hot, soll mer mi'lich schtēle gråd fun der kū wek un si ei gebe. (Be, $C, L b, L h, M r, M t, N a, S c$; Freiburg)

To cure whooping eough, steal milk from a cow and give it to the child.

1799. Wạnn ēns der blō hūsch'te hot, soll mern oi lēne fun leit âs îr nåme net ferlēğelt hen, 's koche un em kind fidre. (C, D, Lb,Lh, Lnc, Na, Sc, Y)

To cure whooping cough, feed the child an egg gotten from persons who have not changed their names by marriage.

1800. Henk en schpinn um der hạls, sell kjūrt blō hūsch'te. (C)

Suspend a spider from your neck to eure whooping cough.

1801. Wạnn en kind blō hūsch'te hot, fạng en schpinn, dũ ${ }^{-}$ si in en sak un henk si em kind å. (Be,Lnc, Na, $Y$; Freiburg)

A spider put in a bag and hung around a child's neck will cure it of whooping cough.

Few spiders tied up in a bag and worn round the neck will keep off fever and ague. W Ir 27

1802. En wusch hōr fume mensch wū sei fạder sei lēbe net gsēne hot kjūrt der blō hūsch'te $(D, L h, L n c$, $M t, S c, Y)$ oder die gichtre $(L b)$ wạmmer der wusch uf der haut nōdråkt. 
A lock of hair of a posthumous child will cure whooping cough or convulsions, if it is worn on the skin.

For whooping cough, a lock of hair cut from the head of a person who never saw his father, is to be tied up in a piece of cloth and worn round the neck. W $\operatorname{Ir} 22$

1803. Fer blōhūschte soll mer butterbrōt $(B e, B u, D, S c)$ oder brōt $(A f)$ oder esse $(A f)$ grìğe fun leit ans ir nåme net ferheiert hen. (Kaiserslautern)

Bread and butter, bread, or something to eat given you by persons who have not changed their name through marriage will cure whooping cough.

To cure whooping cough, let the patient be taken to the house of a married woman whose maiden name is the same as that of her husband and let her give the invalid something to eat-_"a piece"-and a cure will speedily follow. $G$ Secot 46

1804. Ens ans der blōhūschte hot sott aus me blōe gschærr esse. ( $C, S c$; Stuttgart)

Eat from a blue dish to cure whooping cough.

1805. Wạnn ēns der blōhūsch'te hot, fangt mern fisch aus em wasser un lossts drå ríche oder losst der fisch ufs schnaufe, nō gēt der hūschte wek. (Lh, Lnc, Sn) To cure whooping cough: take a fish out of water and let the sufferer smell at it or let the fish breathe on the sufferer.

To cure whooping cough put a trout's mouth into the patient's. $V S L 2.501$; W $\operatorname{Ir} 13$

1806. Wann en kind der blōhūsch'te hot, soll mers dærich en tonnel nemme. $(L h)$

Cure a child of whooping cough by taking it through a tunnel.

To cure whooping cough a child should be carried through the smoke of a limekiln, or through gas-works. $V S L 2$. 501 


\section{HAIR}

1807. Aus'gschtrēlte hör dærf mer net ferbrenne schunscht wært mer dumm. (C, Lb, Lh, Lnc, Na, Nu, Y; Heidelberg)

Burning one's combings makes one stupid.

1808. Ausgschtrēlte hōr ferbrenne ferūr'sacht kopp'wē. $(C, D, M r, N u, S c, Y)$

Burning combings causes headaches.

1809. Wămmer aus'gschtrēlte hōr ferbrennt gēn em noch mēr aus. $(C, S c)$

If you burn your combings, you will lose still more hair.

1810. Hör dærf mer keni ferbrenni, 's mạcht em dumm. $($ Lnc, Na)

Burning the combings of your hair makes you stupid.

... Dumm und tappig. Hlbg.

1811. Hōr im Lēb âbgschnitte wærre dik, schtærik un lạng. $(B u, D, L b, L n c, M t)$

Hair cut in Leo will become heavy, strong and long.

Im zeichen des Löwen und im wachsen des mondes werden die haare geschert. Höf 76

1812. Wạmer hōr nausschmeisst sō as di feğel neschter mit baue wært mer blot. ( $B e, B \hat{u}, C, D, L h, L n c, M t$, $\mathrm{Na}, \mathrm{Sc}, \mathrm{Y}$ )

If you throw your hair out and birds build nests with it, you will become bald.

Wenn man abgeschnittene haare in das freie wirft und die spatzen damit nester bauen, bekommt man einen ausschlag auf dem kopf. $Z 181$

1813. Wannd en weissi hör rausroppscht kumme sibe ann $t r$ leicht. (Be, Lh; Heidelberg)

If you pull a white hair, seven will come to its funeral. 
1814. Rōte hōr uf em kopp, der deibel im leib. (D, $Y$; Lustnau)

Red hair indicates a "spit fire". $C S A 125$

1815. Mer wært fergesslich wạmmer sich ō̋eds schtrēlt. (Be, Bu, Lnc, Mt, Na, Sc, Sn, Y; Heidelberg)

Combing the hair after dark makes one forgetful.

1816. Wammer sich ō̄eds mit me feine schtrēl schtrēlt wært mer fergess'lich. $(\mathrm{Na})$

If you comb after dark with a fine toothed comb it will make you forgetful. $C S A 1291$

...verzerrt man den verstand. Hlbg.

1817. Wann em en schpekmaus uf der kopp fllkt grikt mer grōe hōr. (Na,Sn, $Y$; Heidelberg)

If a bat flies on your head you will get gray hair.

1818. Aus'gschtrēlte hōr muss mer ærğets ạme dunkle blạtz hallte schunscht grikt mer koppwē. (Lnc)

Unless combings are kept in a dark place you will have much headache.

Abgeschnittene haare muss man an einen ort hinlegen, wo weder sonne noch mond scheint, also in die erde unter einen stein und dgl. Baut ein vogel mit solchen haaren, so bekommt man kopfweh. V A S 1.493

1819. Mer losst sich's ërschtmol ballbt're im neie licht, nō grikt mer dike wiskers. (Lnc)

Shave for the first time at new moon if you would have a heavy beard.

1820. Di hōr schneit mer im zu'nemmede àb. (Af; Heidelberg)

Cut hair in the increase of the moon.

1821. Rōte hōr un ąle heke

Wąxe selte uf güte fleke. (Be, $M t, N a, Y)$

Red hair and smooth alder (Almus serrulata) seldom grow in good soil.

... Wachsen selten auf gutem boden. Hlbg. 
1822. Wămmer sichs uf der kopp reğere losst dærich di hunnsdåk gēn em di hōr aus. ( $B e, C, L h, L n c, S n$, $Y$; Heidelberg)

Rain falling on the bare head during dog days will cause the hair to fall out.

1823. Wănns em in de hunnsdàk uf der kopp reğert grikt mer fîl koppwē. $(B e, L h, L n c, S n, Y)$

You will have much headache if rain falls on you head during the dog days.

1824. Aus'gschtrēlte hōr soll mer net wekschmeisse, schunscht wănn feğel neschter mit baue grikt mer koppwē. $(A f)$

If birds builds nests with the combings of your hair, you will suffer with headaches.

Abgeschnittene haare soll man verbrennen oder vergraben, denn sonst werden sie von vögeln zum nesterbauen benutzt und dies verursacht kopfweh. $Z 180 ; S H S 237$

1825. Di hōr ąs es gebt wạmmer sich schēre losst soll mer net wekschmeisse, schunscht wann di feğel neschter mit baue grikt mer koppwē. $(B e)$

Never throw away hair that has been eut off, for, if birds build nests with it you will suffer with headaches.

The cuttings of your hair should not be thrown where birds can find them; for they will take them to build their nests and then you will have headaches all the year after. Ir 2.105

1826. Hōr losst mer immer im zunemmede a abschneide. (Af)

Hair should be cut in the increase of the moon.

Bei zunehmendem monde muss man haare und nägel schneiden. $W u 58 ; C S A 1132 ; V S L 2.1 .248$

1827. Wannd dich schtrēlscht mit me dōde seim schtrēl fâlle di hōr aus, oder wannd dich balbín'rscht mit seim bălbir'messer un schneitscht dich hēlts net. (Af) Your hair will fall out if you use a dead person's comb, or if when shaving with a dead man's razor you cut yourself, the wound will not heal. 
Kamm und messer, womit ein toter gekämmt und geschoren worden ist, muss mit in den sarg gelegt werden, sonst fallen denen, die sich ihrer bedienen, die haare aus, oder er schneidet sich damit schwer heilende wunden. $B S$ 33. 120

1828. Di hōr gēn em net aus wammer sich der ērscht Freidåk im neie licht schēre losst. (Af; Heidelberg)

Hair will not fall out if cut on the first Friday in new moon.

1829. Wạn em en schpekmaus uf der kopp sēcht, wært mer blot. ( $B e, B u, C, D, L h, L n c, M r, M t, S c, Y)$

If a bat wets your hair, you will become bald.

Wenn man bei nacht ohne kopfbedeckung ausgeht, so pissen einem die fledermäuse auf den kopf und man bekommt einen kahlkopf. $Z f D M 4.47$

1830. Wạn em en schpekmaus in di hōr kummt, wært mer blot. $\quad(B e, B u, C, L b, L h, M r, M t, N u, Y)$

If a bat gets into your hair, you will become bald.

Wenn man bei nacht ohne kopfbedeckung ausgeht, verwickeln sich die fledermäuse ins haar. $Z f D M 4.49$

1831. En weibsmensch soll ken mann schēre oder si nemmt em sei grefte. ( $B e, L b, L n c, S c, S n, Y ; H$ idelberg) If a woman cuts a man's hair he will lose his strength.

1832. Im a án'nemmede soll mer sich net schēre losse, schunscht wært mer blot. (Af; Heidelberg)

Cutting the hair in the decrease of the moon causes baldness.

1833. Dæ'rich di hunnsdåk dæ'ref mer di hōr net wesche oder mer grikt gschwǣre. (Be,C,D,Lb,Lh,Lnc, $\mathrm{Mr}, \mathrm{Na}, \mathrm{Sc}, \mathrm{Y}$; Freiburg)

The scalp should not be shampooed during the dog days for fear of boils.

Bathing in the dog days is more dangerous than at other times. $V S L 2.615$ 
1834. Di hōr ans mer sich ausschtrēlt sott mer ferbrenne. $(B e)$

The combings of your hair should be burned.

Combings of hair should be burnt. VS L 2.166

1835. Wămme kind di hōr iøernạnnernei ${ }^{\prime}$ leie gebts en li'derlicher mensch. (Lnc)

The child whose hair is stubborn will become vicious and immoral.

Hat ein kind verschiedene haarlagen, wird es ein liederlicher mensch. $Z 34$. 


\section{SEX}

The superstitions under this rubric are printed in a separate fascicle which will be sent on request to those subscribers of the book who want it for purely scientific use. 



\section{MISCELLANEOUS}

1913. Di nærre fer glik, di ạrme fer kinner. (Af; Heidelberg)

Fools for luck, the poor for children.

1914. Wǣr mit feier schpilt pisst ins bett. (Af)

If you play with fire you will wet the bed.

Welcher mit einem finger oder stecken in die äsche schreibt oder mit dem feuer spielt, das ist ein wahrhaftig zeichen, dass er ins bett gebrunzt hat oder wird's tun. $Z f D M$ 3. 312

1915. Wămmer schtol'pert gēt mer zurik' un duts i'Đer. $(B e, B u, C, L h, L n c, M r, M t, N a, S c, S n, Y)$

If you stumble, go back and start over again.

Wenn einer mit dem fusz anstosst, so er zur haustür hinausgeht, solle er wieder zurückkehren, wolle er anders kein unglück auf dem weg erleiden. $A S 1.378$

1916. Wạmmer i’Ђerm schpille alles gewinne will, muss mer re schpekmaus 's hærz leђen'dich rausschneide un an di hand binne wū mer raus schpilt mit. $(B e, C$, $D, L b, L n c, M r, M t, S c, Y)$

If you would win at cards, cut the heart out of a bat alive, and tie it to the hand with which you deal.

Binde mit einem roten seidenen faden das herz einer fledermaus an den arm, womit du auswirfst, so wirst du beim spiel alles gewinnen. $Z 619$

1917. Wạmmer ạm năğle is un schlecht oft nēbe drå, secht mer als : dir waxt er noch. $(B e, B u, D, L h, L n c, M r$, $M t, N a, S c, S n, Y$ )

If in driving nails you miss them frequently, the saying goes: You are not yet full grown.

1918. Mer soll nix fun der schtrōss ufhēbe, 's is ferleicht gebraucht wærre mit. (Be,C,Lb,Lh,Lnc, Na,Sn, $Y$ ) 
Never pick up anything from the street, it may have been used in powwowing.

Einen bändel mit knoten soll man nicht vom weg auf heben; wer einen aufhebt, bekommt warzen. $V A S 1.499$

1919. Ziğei'ner kenne mē dū $\bar{u}_{\text {as }}$ annnere leit. (Bu, $C, L n c$, $\mathrm{Na}, \mathrm{Nu}, \mathrm{Sc}$ )

Gipsies can do things that other people can't.

Zigeuner können und wissen mehr, als andere leute. $Z 600$

1920. Wămmer ebbes leicht aus'wennich lærne will lëkt mers buch u'nichs koppekissi wănmer ins bett gēt. (Be, Bu, C, D, Lnc, Mt, Sc,Sn)

If you want to learn anything by heart put the book under the pillow when you go to bed.

Wenn man das buch, woraus man lernen will, unter das kopfkissen legt und darauf schläft, merkt man das zu lernende leichter. $Z 281$

1921. Der ē'wich jēğer $(B e, D, L b, N u)$, der sibe jēğer $(B e$, $C, D, L b, L h, N u, Y$ ) hot sei ${ }^{\sim}$ hauns bei sich, blōst sei hærn un jåkt di leit in eng'schte.

The Spirit Hunter is accompanied by his hounds, blows his horn and terrifies the people.

Und schiesst nichts. Hlbg.

Gespenster zogen äberall herum in ganzen schwärmen, der wilde jäger machte jagd, mit ketten fing um mitternacht ein unhold an zu lärmen. $A S 1.372 ; W u 17,18$

Gabriel's hounds sounded exactly like the questings of a dozen beagles on the foot of a race but not so loud, and highly suggestive of the supernatural. $H N C 130$

1922. Wạn ebber schlöft un mer dut em sei físsōle in warm wassser brunst er ins bett. (Be, D, Lh, Lnc, $M t, N a, N u, S n$; Heidelberg)

Applying warm water to the feet of a sleeping person will make hin wet the bed.

1923. Mer kann ēns ins bett brunse mache wammerm di hend in wårem wassser lēkt. ( $M t ; H$ idelberg)

Putting a sleeping person's hand into warm water will make him wet the bed. 
1924. Wǣr ląnge finger hot schtēlt gǣrn. (Af; Heidelberg)

A person with long fingers is likely to be a kleptomaniac.

1925. Wạmmer sich $\mathfrak{a}^{\sim}$ dut un dut di schū 's letscht $\mathfrak{a}^{\sim}$, muss mer sich noch scheme. (Be, Bu,C,D, Lh, Lnc, Mr, $\mathrm{Na}, \mathrm{Nu}$; Heidelberg)

If you put on your shoes last while dressing, you will have cause to feel ashamed.

1926. Wammer di schū å dut fer de hose muss mer sich scheme. ( $\mathrm{Na}, \mathrm{Y}$; Freiburg)

You will have cause to feel ashamed if you put on your shoes before putting on your trousers.

1927. Wạmmer de mannnsleit îr hemmer um em bukel bi'ğelt wærre si bēs. $(C, N a, Y)$

Ironing the backs of men's shirts makes the men irritable.

1928. Di hemmer dærf mer net uf em bukel biğle oder mer grikt en bēser mannn. (C, Na, Sn; Nürtingen)

Ironing the backs of shirts forebodes a crabbed (future) husband.

1929. Di hemmer soll mer net uf em bukel biğle oder mer grikt bu'kelwē. $(B e, D, L n c, N a)$

Ironing the backs of shirts causes lumbago.

1630. Di hemmer soll mer net uf em bukel biğle oder mer grikt gschwǣre. $(L h, S n)$

Ironing the backs of shirts causes boils to the wearer.

1931. Wammerme manns'kærl sei hemm uf em bukel biğlt wært er faul. (Be, Bu, Lh, Lnc, Sn)

Ironing the back of a man's shirt makes him indolent.

1932. De mannsleit ir hemmer dærf mer net uf em bukel binne oder si griğe rik'wē. $(L h)$

Men shirts must not be tied on the back, it causes backache. 
1933. De mannsleit tr hemmer dærf mer net uf em bukel binne, si wærre so bēs. $(L b, Y)$

Men will become very angry if you tie their shirts on the back.

1934. Di hemmer dærf mer net uf em bukel biğle schunscht biğelt mers glik raus. ( $L h, L n c, S n, Y$; Nürtingen) If you iron the back of a shirt the wearer will not have any luck.

1935. Wạmmern neii sūt 's ǣrscht mol å dut muss mer der schneider rausglobbe oder si wërt net gūt. $(N u, S c)$ When wearing a suit for the first time, it must be beaten to beat the tailor out of it, or it will not wear well.

Wenn einer ein neues kleid anhat, soll man ihm darauf schlagen mit worten: "das neue muss man klopfen, das alte nuuss man stopfen"; dadurch bekommt das kleid längere dauer. $G 3.922$

1936. En neii sūt soll mers ērscht mol in di kææ rich å dū̃ , nō wårt si fill lenger. $(B e)$

Wear a new suit for the first time when you go to church, and the suit will wear much longer.

Wear a garment for the first time on Sunday and it will wear twice as long. $V S L 2.1 .253$

1937. Wǣr der wipperwill ( $L h)$ oder gu'kuk ( $A f)$ 's ērschtmol frijōrs hērt soll sei ${ }^{\sim}$ geldsăk schittle, nō hot er immer geld.

You will always have money if you shake your purse when you hear the call of the whippoorwill or cuckoo for the first time in spring.

Wer im frühjahr zum ersten mal den kuckuk rufen hört und kein geld in der tasche hat, leidet das ganze jahr mangel; hat er indess welches bei sich, wird er in dem jahr keine not haben. $B S 33.121 ; V S A 1.124$

On first hearing the cuckoo, turn the money in your pocket and wish for something. VSL 2. 1. 280

1938. Wămmer friłjōrs der wipperwill' 's ǣrscht mol hērt, soll mern bærzlbạm schlăğe, nō grikt mer ken rikwē. $(C, S c)$ 
Turn a sommersoult when you hear the call of the whippoorwill for the first time in spring and you will not have any backache.

Sieht der bauer zum erstenmal im jahr den storch, so wirft er sich zu erde, wälzt sich herum, und bleibt nun das ganze jahr frei von rückenweh. $G 3.986$

1939. Wåmmer der ēsel nennt,

Kummt er gerennt. (Af; Heidelberg)

Speak of the devil and you will hear the flopping of his wings.

Wenn man an jemand denkt oder von ihm spricht, ist er nicht weit. $B S 33.135$

Talk of the devil and he'll appear. VS 2.1.320

1940. Kąlte hend, wårm hærz. (Af)

Cold hands and a warm heart.

Kalte hände, warmes herz. $Z 357$

A cold hand and a warm heart. $V S L 2.1 .294$

1941. Wạmmer sạls ferschitt gebts schtreit. (Af)

Spilling salt means a quarrel.

Wenn das salzfasz umfällt, bedeutet es zank. $\quad R A 290$

To upset salt is exceedingly unlucky and a bad omen. $I r$ 2. 104

1942. Wannd sals ferschitt hoscht, schmeiss defun' iber di links a aksel. $(C, S c, S n)$

When you have spilled salt throw some of it over the left shoulder.

To upset salt is exceedingly unlucky and a bad omen; to avert evil gather up the salt and fling it over the right shoulder into the fire, with the left hand. Ir 2.104

1943. Schtreit zu ferhite wạnnde sạls ferschitt hoscht, ferbrenn defun'. (Af; Neustadt)

To prevent a quarrel when you have spilled salt, you should burn some of it.

To avert the evil from upsetting salt, gather up the salt and fling it over the right shoulder into the fire, with the left hand. Ir 2. 104 
1944. Wū schwąlme hĩ baue schląkt ken giwit'ter ei . (Af)

Lightning will never strike a building where swallows have built their nests.

Wo die schwalmen nisten, schlägt der blitz nicht ein. $Z$ 756

It is good luck to have swallows or martins build in the eaves or chimneys. $\quad V S L 2.17$

1945. Wạnnd rūich schlōfe witt, schtells bett gēğe nærde. (Lh; Heidelberg)

Your bed should face the north, if you wish to sleep soundly.

It is good luck to sleep with your head and feet lying north and south. $V S L 2.21$

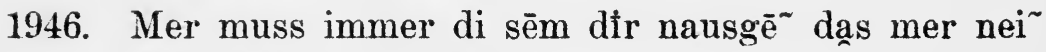
gèt. (Af; Heidelberg)

Always leave by the door by which you enter.

It is ill luck to leave the church by a different door from that you came in at. $V S L 2.93$

1947. Wǣrn himmelsbrif im haus hot, hot ken unglik. (Be, $C, L b, L h, L n c, N a, S c, S n, Y)$

The "letter of Jesus Christ" protects the house in which it is found from misfortune.

cf. $V A S 1.201-2 ; R A 292$

In the south of England a copy of the apocryphal letter of our Lord to Abgarus, King of Edessa, is often pasted on cottage walls to prevent witcheraft. $H N C 194$

1948. Weibsleit wū peife un hinkel wū grēe

Soll mer der hals rumdrēe. (Af)

Whistling girls and crowing hens come to a bad end.

Ein huhn, das kräht wie ein hahn, deutet unglück an. Man soll ihm den hals umdrehen. $R A 289$

1949. Ich winsch dern glik'sēlich jōr

Fun hìr an bis ans scheierdōr,

Der kopp foll leis, der årsch foll grind

Un jēdes jōr en hūrekind. $(B e, L h)$ 
I wish you a happy new year

From here to the barndoor, A lousy head, a scabby arse, And each year a bastard child.

I $k$ wünsche jich en slechtet niet jâr Hunderdûsend lûse up einen hâr,

En kopp vull schörwe

Un en ârs vull wörme. $R A 233$

1950. Di schū un schtrimp muss mer im bett aus- und å dū $^{-}$ nō bleibt mer lang schē $\bar{n}^{\sim}$ ( $B e, B u, L n c, M r, M t, N a$, Sn; Kaiserslautern)

To retain your beauty you should take off and put on your shoes and stockings in bed.

1951. Der ērscht schuss wū mer aus re neie flint schist

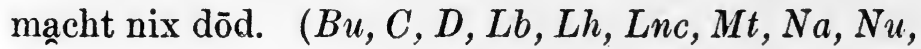
$S n)$

The first shot from a new gun will not kill.

Den ersten schuss feuert man in die luft. Hlbg.

1952. Wạnde fîl rạtte hoscht, dū $\sim$ en sent in en bexli un dråks uf en greizwēk, nō wærre si fergē $\overline{-}^{\sim} \quad(B e, L n c)$ To get rid of rats : put a cent into a small box and lay the box on a crossroad.

1953. Mer soll ken buch iber nacht uf leie losse oder mer fergesst alles a mer drin gilærnt hot. $(B e, D, Y)$

Never let a book lie open at night, or you will forget all you have learned in it.

Du bist eine schlapp, mach doch dein buch zu. Hlbg.

1954. Wạmmern năğel dærich en gnærre schlăğe will reibt mern a an ēnre seit der nås nuf un di annner nunner; nō ferschplit der gnærre net. (Lnc)

To drive a nail through a knot without splitting the board, rub the nail up one side of the nose and down the other.

1955. Rōthōriche leit un fixgeil hen $\overline{\mathrm{e}}^{\sim} \operatorname{sinn}-\operatorname{si}$ sinn alle zwē falsch. $(B e, C, D, L b, L h, L n c, M r, N a, N u, S c$, $Y)$ 
Red-haired persons and sorrel horses are both treacherous. Rothaarigen leuten soll man nicht trauen, denn sie sind bös und falsch. $Z 169$

1956. Schwōbe oder wănze zu ferdreibe, binn drei ąlte sent un drei schwōte oder wanze in en sak un lēk si uf en greitschtrōs. Wǣr der sạk ufhēbt kåft di schwōbe oder wanze. $(A f)$

To get rid of roaches or bedbugs, put three of them and three old cents into a bag and place them on a cross road. Whoever picks up the bag buys the roaches or bed bugs. Wanzen vertreibt man, wenn man in der karfreitagsmitternacht eine schachtel voll auf einen kreuzweg stellt. Wu 398

1957. Schwōbe kạmmer lōs wærre wămmer si in re mątches bax oder é'nichre bax mit me dekel uf en greitzschtrōs dråkt. (Lnc)

To get rid of roaches, put them into a match box or any box with a lid and place it on a cross road.

1958. Mer schneit sich en gạ̄bel fume hạselnisbåm wămmer suche will fer wạsser. Mer hēbt di gånbel in der hand un wī si sich nun'nerzìkt, dært kammer wasser finne wạmmer dìf ginunk' gråbt. $(B e, B u, C, L b, L h$, Lnc, $N a$ )

Use the divining rod when in search of a spring or well. Cut a v-shaped twig from a hazle tree, hold it in your hand; where it dips, you will find water-if you dig deep enough.

The Divining Rod is known also as the Drowsing Rod, Moses' Rod, and the Virgula. It is a v-form twig, each limb being from ten inches to twelve inches long, cut from a cherry tree, hazle or white thorn. It is used for the purpose of discovering subterranean water springs and lodes of ore. $H 99$

1959. Wămmer fer wasser suche will nemmt mern abbel na्scht anschtătts en hạselnisna scht. $(C, M r, S c$, $S n)$ 
Cut a v-shaped twig from an apple tree instead of a hazle tree for use as a divining rod.

1960. Wămmer fer wasser suche will schneit mer sich en pær'sching zweik fun dem jōr. $(D, N u, Y)$

Cut a v-shaped twig of the year's growth for use as a divining rod.

- 1961. Schtreich en rōtseidner bendel t'tøer wildfei'er. (Be, Lnc; Heidelberg)

Pass a red silk cord over parts affected by erysipelas.

1962. Wămmer ēns ạm grōse zēe hălt grikt wạnns im schlōf schwetzt, sakkts em è'nich ebbes ås es wēs. ( $A f)$

If you seize a person by the great toe while he is talking in his sleep, he will tell you anything he knows.

Will man von einem schlafenden geheimnisse erfahren, fasse man ihn an der grossen zehe und frage ihn herzhaft, was man will. Nur muss man sich hüten, den namen des schlafenden zu nennen, weil er sonst erwacht. $V$ A S 1.497

1963. 'S bog'gi oder der wăğe ferbrecht der, wannd i'berm wăğeschmire di reder zurik'zus drēscht. $(L b, M r$, Sc)

Your buggy or wagon will break down if you turn the wheels backward when greasing them.

1964. Wạmmer di reder zurik'zus drēt wạmmer der wăğe schmirt kumme di hexe hin'ich em. $(C)$

Witches will bother you if you turn the wheels of a wagon backward when greasing them.

1965. Wạmmer di reder zurik'zus drēt i'term wăğe schmîre, wærn di geil fălsch. (C,D,Mr, Mt, Na, Sc) If you turn the wheels backward when greasing them, your horses will balk.

1966. Wămmer i’berm wăğe schmîre di reder zurik'zus drēt wært der wăğe ăllemol hēs ans mern jūsd bis mer der wăğe wider rumschmirt. (Lnc) 
If the wheels are turned backwards in greasing a wagon, an axle will become hot every time the wagon is used until all wheels are greased again.

1967. Iberm wăğe schmîre dærf mer di re'der net zurik'zus drēe schunscht gèt der wăğe hært, oder wănmern gūti låd glåde hot, dēt mer schtåle. ( $B u, C, L n c, M r$, $M t, S c, Y$ )

In greasing a wagon, do not turn the wheels backward or the wagon will run hard; or if the wagon is heavily loaded, it will be stalled.

Beim einteeren der wagen fängt man immer rechts an, sonst werden die pferde müde. $W u 406$

1968. Wạn ebber uf me an'nere mann seim lạnd schise gēt, brauch di frå wũ uf em lạnd wūnt juscht der schærz iber di schulter schmeise, nō gēt em jēğer 's gewēr net lōs. $\quad(B e, L h, L n c, S c)$

If any one trespasses on another's land for the purpose of gunning the former's wife needs only to throw her apron over her shoulder and the gunner's gun will miss fire.

Ein altes weib verhindert dem jäger das treffen, wenn sie die schürze mit einem zipfel aufschürzt. $W u 291$

1969. Di leit wū î sạch immer im haus rum'schtelle kumme zu nix.

If you keep moving your furniture around, you'll be poor. $C$ S A 1456

..Sind unstete menschen. Hlbg.

1970. Al'lemol a as mer sich jērt soll mern fåsenachtkuche esse nō lebt mer noch en jōr lenger. ( $L b, L n c, S n$; Lustnau)

Eat a doughnut on your birthday and you will live another year.

1971. Wǣr en ǣrdschpiğel hot kạnn ē'nich ebbes sēne. Mit sō me schpiğel kânmer meind un lecher in der $\bar{x}$ rd finne. $(Y)$

You can see anything by the aid of a semaphora. It is also used to discover ore or subterranean caverns. 
Der erdspiegel entdeckt personen verborgene schätze und andere verborgenen dinge. $W u 245$

1972. Di flint soll mer butze mit em hærz fun re schpekmaus, nō drefft mer a्lles a mer denno' schtst. (Be) Swab the gun with the heart of a bat and you will hit anything that you aim at.

Unfehlbaren schuss erlangt man, wenn man eine lebendige fledermaus zerreisst und die kugeln in das blut taucht. $W u 452$

1973. Mer soll nî net ebber en nōdel oder schpel mit em schpitz'iche end gete schunscht ferschtechts di lib. (Af)

In giving a needle or pin or any pointed instrument to any one, never hand it with the point toward the person, for it will destroy your friendship.

Der verleiher einer steck- oder nähnadel darf sie dem leihenden nicht selbst in die hand geben, sondern vor ihm hinlegen oder hinstecken, sonst werden sich beide feindlich gesinnt. $B S 33.142$

1974. En weibsmensch as ems brōt dik schneit macht en güti schtífmutter. $(A f)$

The woman that cuts thick slices of bread will make a good stepmother.

Weil sie einem nichts drauf schmieren will. Hlbg.

1975. Wạmmer feğelneschter finnt un schwetzt åm disch defun' gēn di schlănge drå . (Lnc, Nu; Kaiserslautern)

If you find a bird's nest and talk about it at the table, snakes will destroy it.

1976. Wămmer uf junge feğel schnauft eb si di åğe uf hen, losse di anlte si ferhungre. $(C, S c, Y)$

If you breathe on young birds before their eyes are opened, the parent birds will let them starve.

Dann gehen sie kaputt. Hlbg.

1977. Wạmmer feğel år rēkt eb si di åğe uf hen, lossi di alte si ferreke. $(B u, C, M r, M t, S c, Y)$ 
If you touch birds before their eyes are opened, the parent birds will let them starve.

1978. Mer soll ken bettschtrik ibers greiz schpannne, mer hot greiz gnunk sō. $(Y)$

The bed cord should not be stretched cross wise, you have cares and sorrows enough without it.

1979. Mer soll ken gnopp ibers greiz å nēe, mer hot greiz gnunk' sō. (Be, Lnc, Na, Sn; Heidelberg)

In sewing on buttons take care not to cross the stitches, lest you add to your sorrows.

1980. 'S wasser fum ērschte schnē is heilich wăsser. (Bu, Lb, Lnc, Mt; Heidelberg)

Water from the first snow is holy water.

1981. En ganz ēr'licher mann muss en pusch hör in der hand ha्abe. $(\mathrm{Na}, \mathrm{Y})$

A perfectly upright man should have a tuft of hair in his hand.

1982. Wǣr re weisse daub di zung rausnemmt un lēkt si sich u'nich di zung kannn dærich en pærtischenwand sēne. $(L h)$

Cut out the tongue of a white pigeon, place it under your tongue, and you can look through a partition wall.

1983. Wạmmer am feiermache is uns will net brenne soll mer drei bēse weibsleit nei $\mathrm{dū}^{\sim}$. (Be, Lnc, Y; Freiburg)

If when you are starting a fire it will not burn, put the names of three scolds into it.

1984. Wǣrn mostąsch' rēse will un kannn net muss di e't̄erscht lefts mit síser råm oder me hin'keldrek schmire un no in re dunkle nạcht en schwærzi katz es ab'schleke losse. (Af; Heidelberg)

If you want to raise a moustache and cannot, rub sweet eream or chickendung on the lip and let a black cat lick it on a dark night. 
1985. Wann en fux'gaul ken naube hot hot sei ${ }^{-}$mẽschter si. (Af; Heidelberg)

If a sorrel is not tricky, its owner is.

1986. Fer jēder schtich as de Sunndåks mạchscht rennt der der deibel en glt'dichi schtriknōdel dærich di zung. $(L n c)$

For every stitch you take on Sunday the devil will run a red hot knitting needle through your tongue.

.. Rennt der teufel in der woch im haus herum. Hlbg.

1987. Wạmmern drạch å rüft grikt mer geld. (Lnc, Y)

Call upon a dragon [or meteor?] for money.

1988. Wann en maulwærf im keller is halts di ratte draus. (Lnc, Nu; Heidelberg)

A mole in the cellar will keep out rats.

1989. Wạmmers maul mit em schpillumbe abbutzt, grikt mern hōrich maul. (Be, Bu,Lb,Lh, Lnc, Mt, Sc; Freiburg)

Wiping the mouth with a dish cloth causes hair to grow on your lips.

1990. Sō ạs en flint gūt dōdmạcht dut mer fum blūt fūme gedí'r as mer gschosse hot in der låf. $(D, S c)$

To give a gun greater power put into the gun barrel some of the blood of an animal you have shot.

Tue blut von einem maulwurf in den lauf zwischen das pulver und blei. Hoh 18

1991. Gē̃ immer zum sēme fạlter naus ąs de nei ${ }^{-}$gēscht. $(A f)$

Always enter and leave through the same bars.

1992. Wannde ebbes ferlōre hoscht, schpau in die hand un schlak mit em finger druf. Wūs menscht schpautz hi̛ flikt, in sellre direk'schen leit wạs mer ferlōre hot. (Bu; Freiburg)

To find something you have lost: spit into the palm of your hand, hit the spittle with one finger and the direction in which the greater part of the spittle flies will indicate where the lost article can be found. 
1993. Wann schanschtẽ schwąlme in en schtub kumme, dråğe si wannze ins bett. ( $B e, B u, L b, L h, L n c, M t$, $S c, S n, Y$; Freiburg)

Chimney swallows bring bedbugs.

1994. Schmǣrte leit mạchens bett mærğets, faule mittåks, sei ōbeds. (Bu; Heidelberg)

Good housewives make the beds in the morning; lazy ones at noon, slatterns and pigs at night.

1995. 'S hot ēner en ærd'lichtel gsēne un hot em drei sent å 'gebote wạnns em hēm leichte dēt. 'S hots gedū , un nō wì er hēm kumme is hot erm di drei sent net gebe wolle, å̄ers hot juscht gewårt bis es si grikt hot. $(L h)$

Once upon a time a man saw a will-o'-the-wisp and he offered it three cents if it would guide him home. Having done so, he declined to give it the promised reward but it just waited until it got its money.

Feuermänner (auch lichterträger, feurige landsknechte) sind ziemlich harmlos, wenn sie nicht beleidigt werden; sind gegen versprochenen lohn, einen kreuzer, einige pfennige oder brotkrumen, dem menschen gefällig, besonders den fuhrleuten die sie rufen, leuchten ihnen nach hause, und dergleichen; gibt man ihnen das versprochene, irgend eine kleinigkeit, nicht, so führen sie den menschen durch die lüfte davon oder zünden ihm das haus an. $W u 477$

1996. Di schåle fun sūme gummere lēkt mer in di fruchtkămmer, di wible zu ferdreibe. $(B e, L h$; Heidelberg)

Put the shells of seed cucumbers into the granary to drive out weevils.

Cucumbers were regarded infallible in driving vermin away. $C P \& P 232$

1997. Wammer hinnerschtfe'derscht schwetzt is mer hinnerschtfe'derscht ufgschtanne. (Af; Heidelberg) If a person jumbles his words in speaking he got up wrong. 
1998. Wạmmer sell bei nåme nennt às an em denkt wạmmer di schpel wider nei schtekt un si bleibt fascht hot mers recht genåmt. (Lnc, Na, Nu, $\mathrm{Y}$; Heidelberg) If the pin, which has become loosened because some one was thinking of you, remains in its proper place, you have guessed the name of the person.

1999. Mærğets rōt, ō’tbeds dōt. (Bu; Freiburg)

Morning red, evening dead.

2000. Wămmer ēm der rok'ærmel nufgukt, sēnt mer schtærne. (Lnc, Nu)

Look up a man's coatsleeve and you will see stars.

2001. Wămmer in der busch gēt un drēt uf ær'graut, ferlîrt mer sich. (Af)

You will lose your way in the woods if you step on rattlesnake plantain.

Wenn man über das kraut hinweg schreitet, ohne es zu wissen, so get man irre (daher irrkraut). $W u 99$

2002. Wạnn pår leit en drạch sēne, solle si net zămme schwetze schunscht fergēt' er gråd. ( $B e, B u, C, L b$, $L h, M r, M t, N a, S c, S n, Y$ )

If several persons see a meteor at the same time they should remain silent, or it will disappear at once.

Wenn man ruft "der drache zieht", so entflieht er. Wu 46

2003. Mer soll ken reche uf der kopp lëğe, schunscht heile di engel im himmel. ( $B e, C, D, L b, L h, M t, N a, N u)$ Do not let a rake lie on the ground with the teeth upwards, it makes the angels weep.

Man soll keinen rechen mit den zähnen nach oben gerichtet liegen lassen, weil es den engeln beim laufen wehe tut, denn die engelein sind barfuss. $V A S 1.492$

2004. Mer soll ken brōt uf der kopp lēğe schunscht heile di engel im himmel. $(B e, C, D, L b, L h, M t, N a, N u)$

Do not lay a loaf of bread on its round side, it makes the angels weep.

Wenn brot auf der runden seite liegt, hat der teufel gewalt darüber. Zf $D M 1.243$ 
2005. Wǣr ēnich ebbes in der pann mit em messer schtærrt, grikt seitschteche. $(L n c)$

If you stir anything in a pan with a knife you will have a pain in your side.

Wer essen oder trinken mit dem messer umrührt, bekommt leibschneiden. $\quad G 3.1052$

2006. Wǣr der kąf'fi oder tē mit em messer rírt grikt seitschteche. $(C, L h, L n c, S c)$

You will have a stitch in the side if you stir coffee or tea with a knife.

Wer essen oder trinken mit der gabel umrührt bekommt leibstechen. $G 3.1052$

2007. Sō fíl schtich ås mer nemmt wạmmer ebbes ån ebber årnēt, sō fîl drēne. $(B e, L b, N a, S c)$

Each stitch which you take while sewing or mending something while the person is wearing it means a tear.

2008. Wạmmer hexe fer grexe zu ebber såkt, kann er net dū was er $\mathrm{du}^{\sim} \sim$ hot wolle. $(B e, L h)$

If you say "hexe fer grexe" to a person he cannot do what he intended.

Man sagt hexe fer drexe. Hlbg.

2009. Wạmmer ebber ebbes årnēt nēt merm schmærze å fer jëder schtich. $(C)$

Each stitch you take while sewing something on a person means one additional pain.

2010. Nē me mensch ebbes å wanners å hot un du nēscht ems glik wek. $(B u, L b, S c)$

You will lose your luck if you permit anyone to mend your clothes while you are wearing them.

2011. Wămmer me mensch ebbes å nēt wannners å hot, nēt merm di gedanke fescht. $(B u, L b, N a, S c)$

If you sew or mend anything on a person he will become thoughtbound. 
2012. Wạmmerme mensch ebbes å̃ nēt wạnners å̃ hot, nēt merm drubel $\mathrm{a}^{\sim}$. $(C, D, L h, L n c, S c)$

You will sow on trouble if you mend any garment while it is being worm.

2013. Wạmmer ebber ebbes å̃ nēt wạnners å hot, grikt ern feind fer jēder schtich. $(N u)$

Each stitch which you take while sewing or mending a garment while it is being worn, means one enemy.

2014. Wạmmerme mensch ebbes å nēt wanners å hot, wært er dumm un fergess'lich. ( $B e, B u, D, L b, L h, M t$, $\mathrm{Na}, \mathrm{Nu}, \mathrm{Sc}$ )

If you mend or sew at a garment while a person is wearing it, the wearer will become stupid and forgetful.

Wer sich das zeug am leibe flicken, einen knopf oder ein band annähen lässt, verliert das gedachtnis, seine kraft oder verunreinigt sich im tode. $B S 33.136$

2015. Wammer gscheid sei ${ }^{\sim}$ will muss mer drei schnitz esse, â̄er net mē. (Af; Heidelberg)

To become wise, eat three pieces of dried fruit, but no more.

2016. Wannde ebbes sēnscht wandre in der nacht uns will der di hand gebe, geb sim net oder si fallt der ab $(C, L b, L h, M r, S c, Y)$. Geb em en schnuppduch. $(Y)$

If a spirit wandering about at night wants to shake hands with you, do not do it, for your hand will drop off. Give your handkerchief.

Wer einen geist fragt, wodurch er erlöst werden könne, muss es auch vollbringen, sonst hat er vor demselben keine ruhe mehr; verspricht man es, so fordert der geist einen handschlag oder ein pfand. Die hand darf man ihm aber nicht reichen, sonst verbrennt sie, weil jener schon vom quälenden feuer ergriffen ist, man darf ihm nur ein tuch oder etwas ähnliches reichen. $W u 483$

2017. Der jut is der gnoche wū der deibel in di sei gfåre is $(B e, B u, L b, L h, M t, S c, Y)$. Er hēst å 's joch.

The atlas bone [?] marks the spot where the devil entered the swine. It is also called the yoke. 
Die sau hat dem "hochrücken" im genick ein wirbelbein, das da aussieht, als sitze ein mädchen im zuber. Dies nennt man die "saujungfer"; wer diese beim essen bekommt, wird ausgelacht-denn es eine jüdin. $V A S 1$. 122

2018. Wạnn en mēdel me mannskærl sei ${ }^{\sim}$ hūt uf'dut, will si en boss. $(\mathrm{Be}, \mathrm{L} h, \mathrm{Na})$

If a girl wears a man's hat, she wants a kiss.

Wenn man einem mädchen einen mannshut aufsetzt, bekommt sie noch sieben jahre keinen mann. $D r 226$

2019. Wămmer fun hēm is un drefft der sēm mensch pår mol seller dåk å , muss ēns defun' trìte, wannn si nanner 's dritt mol å dreffe. $(B e, L h)$

If, when away from home, you meet the same person the third time in one day you must treat him.

Wenn zwei menschen an demselben tage einander öfter begegnen, so ist einer dem andern etwas schuldig. $W u$ 208

2020. Wạmmer ăm sēf koche is uns schmeist em ebber brōt oder brōtgrimmle in der kessel wært di sef nēt. ( $L h$ ) If while boiling soap, some one throws bread or breadcrumbs into the kettle, the soap will not be a success.

Wenn beim butterausrühren der rahm nicht brechen will, wirft man drei brotbröckelein in den drei höchsten namen ins rührfass, so geht's bald aus. VAS1.397

2021. Wạmmer ạm sēfkoche is uns kummt en mannskærl, muss er si schtærre, no gebts sēf. $(C, S c, Y$; Lustnau)

If, when you are boiling soap, a man happens along, make him stir it, or the soap will not come.

2022. Iநerm sēf koche muss mer mit me săs'sefrąs schteke rire. (Lh, Lnc, Mr)

When making soap, stir it with a sassafras stick.

To make soap, stir it with a sassafras stick in the dark of the moon. AF J 14.33 
2023. Wąmmer ąn der mæ'rik gēt, soll mer der ērscht kēfr net ge $\tilde{e}^{\sim}$ losse schunscht kammer sei ${ }^{\sim}$ săch seller dåk net ausferkåfe. $(A f)$

If you attend market, don't let the first customer leave without making a purchase, or you can't dispose of your goods.

Wer mit waare zum markt geht, darf den ersten käufer nicht gehen lassen, auch wenn er ihm noch so wenig bietet. B S 33. 140

2024. Wạnn in re fạmi'lie lauter būbe sin un noch ken mēd, dânn hēscht der letscht bū Ådam, nō gebts mēd. ( $C$, $M r, Y$ )

To break a succession of male children in a family, one of them should be named Adam and the next child to be born will be a girl.

2025. Wạmmern neii sūt grikt uns ērscht mol å dut sott mer ebbes gschenktes drå oder drin hā̄e schunscht hot mer ken glik mit der sūt. Fer di ūr'sach bettle sich ftl mannsleit en pår ho'sedrēğer mit der sūt. $(A f)$

The first time you wear a new suit it should contain a present of some kind. For this reason many men request that a pair of suspenders be included.

Wer ein neues kleid zum erstenmal anzieht, darf es nicht leer anziehen, sondern muss sich vorher irgend etwas schenken lassen und in die tasche stecken, sonst hat er in und mit dem kleid kein glïck. $B S 33,247$

2026. Wạmmern năğel fun re låd ime díb sei fūssdąbbe schla kxt, grikt ern wēer fūss. ( $L n c, N a, S n)$

If you drive a coffinnail into a thief's footsteps he will get a sore foot.

Sargnägel in die fussspuhr eines diebes geschlagen wirken dessen tod. $W u 135$

2027. Fer glik ąn der lotterí' dråk en schpekmaushærz im bakkebuch nō. (Be, Lnc, $Y)$ 
When playing the lottery, carry the heart of a bat in your wallet.

Ein fledermauskopf im geldbeutel bringt ihm gewinn. $Z$ 776

2028. Mer soll der kopp fun re schpek'maus nōdråğe, nō gewinnt mer alles as mer schpilt defor'. (Be,Lnc)

Carry the head of a bat with you to bring luck in any game. Ein fledermauskopf im geldbeutel des spielers bringt ihm gewinn. $Z 776$

2029. Dråk en schpekmaus hærz im sąk nō, wannnde gewinne witt i'berm kårte schpíle. $(B e, C, M r, S c)$

Carry in your pocket the heart of a bat if you would win at cards.

Glück im spiel hat, wer das herz einer eule, den stein aus dem rücken einer fledermaus oder den kopf eines weidhopfs bei sich tragt. $G 3.251$

2030. Wămmer en lēb brōt 's un'nerscht 's e'terscht hí lëkt, gebts schtreit. $(B e, C, L h, N a, S n, Y)$

If you place a loaf of bread on its head, you will have a quarrel.

Man soll das liebe brot nicht auf dem rücken liegen lassen. G 3.278

2031. Wănnd der ellbōğe weder rennscht duts so wē ąs wămmer sei mann ferlitrt oder a wa wann em der mann schtærbt. $(B e, B u, C, D, L h, M r, M t, S c$ : Kaiserslautern)

A blow on the crazy bone is as distressing as the loss or death of one's husband.

2032. Wạmmern kopche ${ }^{\sim}$ [kaf'fi] ausschitt un nōs kopche wider ufschtellt kammer såğe wt fil leit ąs uf bsuch kumme bei de ring as im kopche $\sin$. $(B e, L b, L h$, $N a, S n, Y$ )

The number of rings in the cup after the coffee has been drunk indicate the number of visitors to be expected. 
2033. Neğel ąs mer jūsd fer fens mạche soll mer in ēl dunke, nō hạlt di fens fill lenger. $(D)$

Fences will last much longer if the nails used in making them are dipped in oil.

..... Dann fault's nicht bald. Hlbg.

2034. Wạmmern blu'meschtok schittelt wąnn en re'ğebōğe schtēt, grikt er sche'kiche blume. (Be, Lh, Lnc, $M r$, $Y$; Freiburg)

If you shake a flowering plant while there is a rainbow, the flowers will be speckled.

2035. Wạmmer ærğets hĩ gschikt wært fer ebbes hōle un schtol'bert oder fallt uf em wēk, gēt mer zurik' un duts i'万er. $(B u, \bar{M} r, M t)$

If you stumble or fall while on an errand you must go back and start over again.

2036. Wạmer gēt ebbes zu hōle un schtol'bert uf em wēk fergesst mer was mer hōle hot wolle. (Af; Heidelberg)

If you stumble while going on an errand, you will forget what you were sent for.

2037. Wạnn en re'ğebōğe ạm himmel schtēt soll 'mern Fạterun'ser bēte. $(\hat{B} e)$

Repeat the Lord's Prayer when you see a rainbow.

Bei einem gewitter kniet man sich in der stube zum allgemeinen gebet nieder. $Z f D M 2.102$

2038. Es hot nachts immer en ǣrdlicht gerūfe: "Wū soll ich en ht d d $\bar{u}^{\sim} q "$ ' 'S is en gsoffner der wēk gąnge un hots kērt, un sei antwort wår : "Ei, dū ferdạmmter ēsel, dūn ht wūd en grikt hoscht." Sell hot di ganz bisness gsettelt. ( $A f)$

Every night an ignis fatuus was heard to say: "where shall I put it?" A drunken man who came along heard the question, and answering said: "Why, put it where you got it, you damned fool." That settled the whole business. 
In sehr vielen fällen kommt es darauf an, dass der mensch das wort der gereehtigkeit ausspricht, um eine verschul. dete seele zu retten. Wenn menschen, die grenzsteine verrückt haben-einer der häufigsten fälle-nach dem tode als feuermänner und dergleichen den grenzstein auf der schulter tragen müssen, so fragen sie jeden vorübergehenden, "was soll ich mit ihm anfangen?" oder "wo soll ich ihm hintragen?" da muss man antworten: "trage ihn hin, wo du ihn weggenommen hast", so ist er erlöst. Sehr oft kommt es vor, dass sehr einfältige, ja betrunkene leute das erlösende wort finden. $W u 482$.

2039. Mer soll ken knecht oder måd færtfåre. (D)

Servants when leaving should not be taken home with the employer's team.

2040. Mer soll sei brendes net færtfåre oder mer hot ken glik un der brendes å net. $(B e, B u, D, L b, L h, N a$, Sc; Freiburg)

It is bad luck to both employer and apprentice if the latter is taken away in the former's conveyance.

2041. En grōsi frå un en grōsi scheier sin kem mann ken schåde. $\quad(B e, C, L b, L h, L n c, M r, N a, N u, S n, Y$; Heidelberg)

A large wife and a large barn bring luck to any man.

2042. Wann em en schpekmaus uf der kopp flikt grikt mer wanze. $(B u, M t, N a)$

If a bat flies on your head you will have bed bugs.

2043. Fill leit sin bạng fer der pærre zu schike ine 's nạcht'mol zu geøe, si mēne si misste schtærøe. (Be, Lh, $\mathrm{Na}$ )

Many persons are afraid to summon their pastor to give them communion, because they are afraid that they must then die.

Manche schieben das abendmahl auf dem kranken bett möglichst hinaus, weil sie glauben dann jedenfall sterben zu müssen. Wu 141 
2044. Wạnnde ebbes ạn der ånnēe losscht ltkt ebber wēich der. ( $L b, L n c, S c)$

If your clothing is mended while on you somebody will lie about you.

If you have your clothes mended on your back, you will be ill-spoken of. $C F$ Suf 1.128

2045. Mer soll nix ạn em å̃nēe losse schunscht nēt mern likk å fer jēder schtich. (C, Lb, Lnc, Mr, Na,Sc,Sn)

If you have your clothes mended on your back you will be ill-spoken of. $D Y 82$

2046. Mer soll nix an em å nēe losse oder mer grikt en feind fer jēder schtich. $(N u)$

An enemy for every stitch will be the result of having your clothes mended on your person.

2047. Wạmmer sich ebbes å̃nēe losscht wạmmers å hot wært mer dumm. (Mt)

You will become stupid if you permit anyone to mend any of your garments while wearing them.

2048. Wạmmer unwissend der schærz letz å dut, soll mern so losse oder mer tschēndzhd sei ${ }^{\sim}$ glik. $(B u, C, D$; $L b, L h, L n c, M t, S c)$

If you put on your apron unwittingly inside out, you must not change it, for by so doing you will change your luck. Wer ein kleidungsstuck verkehrt anzieht, hat glück. $A J$ 250

2049. Mer soll ken pre'sent mache zu seim beschte freind funre schpel oder mer ferschtecht di líb, oder fume messer oder re schēr oder mer ferschneit si. (Af)

Never present a friend with a pin, knife or scissors, or you will puncture, sever or eut the friendship.

Es darf kein freund dem freunde ein schneidendes oder spitziges instrument, als messer, scheere u.s.w. schenken, es zerschneidet die liebe oder freundschaft. $B S 33.118$; G 3.87 
2050. Des wū braucht dærf ken breis mache fer sei ${ }^{\sim} æ r^{\prime}$ bet schunscht bats nix. (Af)

Powwowing will be of no avail if the powwower sets a price on his work.

Für ihre kuren dürfen die weisen leute niemals etwas fordern, sonst helfen sie nichts; sie dürfen nur freiwillige geschenke annehmen. $W u .147$

Another important character whose supernatural powers are still credited is the "charmer." She is generally an elderly woman of good reputation and supposed to be gifted with extraordinary powers by means of which she performs her wonderful feats of skill. By her incantations and mysterious ceremonials she stops blood, cures all manner of diseases and is, in short, regarded as almost a miracle worker. ... These supposed charmers do not always, however, make a trade of their art; for on the contrary, it is suposed by some of them that any offer of pecuniary remuneration would break the spell and render the charm of no effect. $D Y 72-3$

2051. Was zwet sich dritt sich,

What happens twice, happens thrice.

Wenn an einem tage zwei gäste kommen wird der dritte bald nach folgen. $Z 391 ; Z f d M 2.421$

If you break two things, you will break a third. $V S L$ 2. 526

2052. Wạmmer gridlich is såğe si als: du bischt mit em linkse fūs 's ērscht aus em bett. (Af)

When one is cross and crabbed, people usually say: you got out of bed with the left foot first.

To get out of bed with the left foot first renders you cross and unfortunate all the day. $E Y 44$

2053. Schū as greische sin noch net bezålt. ( $B e, B u, C, L b$, $L n c, M r, M t, N a, N u, S n)$

Creaking shoes are still unpaid.

Wenn die stiefeln oder schuhe knarren, dann sind sie noch nicht bezahlt. $W u 212$

If your new boots creak, the shoemaker is still unpaid. $E$ Y 45. 
2054. Nemm en hōr fume mensch un złk si zwische em daumenăğel ume fingernăğel dæ'rich. Wann di hōr sich ufgrollt, is seller mensch schpankich. $(B e, B u$, $L h, M t)$

Scrape the thumbnail and a fingernail along a hair. If the hair curls the owner is high-tempered.

Solch ein mensch ist recht zornig. Hlbg.

To find out if a person is proud. Take a hair of the head and pull it tightly between the nails of the first finger and the thumb. If it curls, its owner is proud, and the amount of curl it takes is the measure of pride. G Scot 26

Scrape the thumbnail and the fingernail along a hair, and if, by the third time it curls up, the owner is hightempered. $C S A 136$

2055. Mer nemmt en ǣrdschpiğel fer geld finne. (D)

Use a semaphora to discover hidden treasures

2056. Di grąbe, eile, woi un so weiter ąs mer schisst, năğgelt mer an di scheier. $(B e, L h)$

Crows, owls, hawks and so forth are shot and nailed to the barn.

Die weihen und hake sucht man dadurch vom hofe fern zu halten, dass man dergleichen tiere mit ausgespannten flügeln an das scheuertor nagelt. $V A S 1.125$

The practice of nailing field vermin (weasles, jays, and others) on the walls of country houses has some magical bearing on certain animals supposed to be embodied witches. VS L 2.1.446

2057. En mēdel mit me dike halls hot dike bē̃ . (Be, $L h$; Heidelberg)

A girl with a fat neck has fat legs.

2058. Wammers brauchbuch ins ek schtellt dreibts all di meis aus. (D)

Place the spellbook into the corner of room and it will drive out all the mice. 
2059. Wammer der ēnunnein'zichscht Psălm im grtk nō dråkt dūn em di kuğle nix. (D)

If you carry the ninety-first Psalm with you in the army bullets will not hurt you.

2060. Wạmmer der wibberwill' hërt soll mer sich rolle nō grikt mer ken fiber. $(B u)$

Roll yourself when you hear a whippoorwill to prevent fever.

2061. Wạmmer der wibberwill' hērt soll mer sich rolle nō grikt mer ken rikwē. $(\mathrm{Na})$

Roll yourself when you hear a whippoorwill to prevent backache or lumbago.

Wenn man den kuckuk hört ... Kl

2062. Wạn ē'nich ebber unner sibe jōr en maul'wærf hēbt bis er dōd is kann er brauche fer ēnich ebbes as fōrfallt. (Be, $B u, D, L b, L h, L a, N u, S c)$

If a person under seven years of age holds a mole in his hand until it is dead, he ean powwow for any thing that happens.

Wenn man einen maulwurf langsam in der hand sterben lässt, so kann man mit dieser hand allerlei übel heilen. $W u 315$

2063. Wạnn en frå gūt feiermache kann hot si en schmǣrter mann. (Be, $D, L b, L n c, N u, Y)$

If a wife can kindle a good fire she has a good husband.

2064. Wạnn en frå gūt feiermache kann grikt si en schmærter mann. (Bu, C, Mr, Mt, Nu,Sc,Sn,Y)

If a woman can kindle a good fire she will get a good husband.

2065. Wạnn en mạnn gūt feiermạche kannn hot er en schmǣrti frå. $(A f)$

If a man can kindle a good fire he has a good wife.

2066. En bē'si frå is gewēn'lich en gūter feiermạcher. ( $A f$; Freiburg)

A scolding woman can usually make a good fire. 
2067. Wammers maul ab'butzt mit em schptllumbe grikt mern hō'rich maul. $(S c, Y)$

If a woman wipes her mouth with a dishcloth she will get a hairy lip.

2068. Wạmmer in en foğelnescht schnauft gēn di ąlte nimmi druf. (Bu, Mt; Heidelberg)

If you breathe into a bird's nest the birds will forsake it.

2069. Wạmmer in en fo'golnescht schnauft wærre di oier faul. (Lnc, Nu; Heidelberg)

If you breathe into a bird's nest the eggs will rot.

2070. Der weschlumbe wū mer en dōdes mit wescht is gūt fer brauche. ( $L b, L n c, S n, Y)$

The washrag used in washing a corpse is used in powwowing.

2071. Wammer feier macht uns will net brenne soll mer drei bēse weibsleit nei dũ $^{2}$. (Be, Lnc, Y; Freiburg)

If you kindle a fire and it does not burn, write the names of three scolds on a piece of paper and throw it into the fire.

2072. Wạnnd en maulwærf in der hand hēbscht bis er dōd is kąnnscht me ann'nere mannn 's glik wek hēbe mit. (Mt; Heidelberg)

If you hold a mole in your hand until it dies you can rob a man of his luck.

2073. Wạmmer wesch'be banne will secht mer dreimol in èm ochtem:

Weschbli, weschbli, schtech mich net, Bis der deibel der sēğe schprecht. (Be,C,Lb,Lh, Lnc, Sc)

To charm wasps so that won't sting, say:

Little wasp, little wasp, don't sting me till the devil pronounces the benedietion.

Wespen, ich bonne euch, beisst ihr mich, bonn' ich euch, fresst ihr mich, derreiss' ich euch. Z Z $D$ M 2.423 
2074. Wanmmer sich im busch ferlöre hot soll mer der rok rumdrēe. $(B u, D, M t, S c$; Nürtingen)

When lost in the woods, turn your coat inside out.

2075. Wannd dich ime busch ferlōre hoscht, guk a me båm nuf. (Nu; Kaiserslautern)

When lost in the woods look up a tree.

2076. Wannd dich im busch ferlöre hoscht drē drei mol rum, nō kummscht wider raus. (Sn; Kaiserslautern)

When lost in the woods turn around three times and you will find your way out.

2077. Wannd dich im busch ferlōre hoscht nemm drei schritt hin'nerschich, nō kạnnscht der wëk wider finne. (Sc; Kaiserslautern)

When lost in the woods take three steps backward and you will find your way out.

2078. Drē dei ${ }^{\sim}$ sek rum wannd dich im busch ferlöre hoscht, nō kummscht wider raus. $(B e, S c, S n, Y)$

If you are lost in the woods, turn your pockets inside out.

Hat man sich im wald verirrt, so muss man die taschen um. kehren, wahrscheinlich um den hineingefallenen irrssamen herauszubringen. $W u 407$

If you have lost your way in the woods, turn your pocket inside out. Corn 123

2079. Wạmmer in der busch gēt un ferlìrt sich, muss mer en schtik glēd letz å ${ }^{2} \bar{u}^{\sim}$, nō kạmmer wider aus em busch. (Be, $C, L n c, S n, Y)$

If you are lost in the woods, take off a garment, turn it in. side out and put it on again.

Hat man sich im wald verirrt, so muss man die schürze verkehrt umbinden. $W u 407$

When you have lost your way turn some article of dress inside out. V S L 2.1.428 
2080. Wammer sich in busch ferlōre hot, wekselt mer sich di schū, nō kummt mer wider raus. ( $B u, L b, L h, M r$, $M t, N a, N u, S c, S n)$

If you are lost in the woods, change your shoes and you will find your way out.

Hat man sich im walde verirrt, so muss man die schuhe wechseln. $\quad W u 407$

2081. Wạmmer sich zwische Grischdåk un Neijör wescht is mers gąnz jōr sauber. (Be, Lnc, $M r, N a, S n)$

If you take a bath between Christmas and New Year you will be clean all year.

2082. Schå5e kănmer færtdråğe wănmer pår in drei glēne hefe binnt un si an di fens henkt. (Be, $L b, L h)$

Rid the house of moths by tying a few into three small crocks and hanging them on a fence.

2083. Wạnn em der schūbendel ufgēt denkt ebber ąn em. Wạmmern nō binnt muss mer den bei nåme nenne wăs an em denkt schunscht bleibt er net zū. ( $A f)$

If your shoe laces become untied some one is thinking of you. In retying them name the person who is thinking of you and the shoe laces will remain tied.

2084. En frå muss me mąnn un en mạnn re frå såğe wt zu brauche, schunscht batts nix. ( $A f)$

The powwowing formula must always be communicated to a person of the opposite sex, else it will lose its effect.

Sympathien müssen sich mäner von frauen und frauen von männern lehren lassen, sonst sind sie unwirksam. G 3 . 793

2085. En gūter feiermącher mạcht en gūter mannn. ( $A f$; Heidelberg)

A man who can kindle a fire easily will make a model husband. 


\section{AMERICANA GERMANICA}

\section{Monograph Series}

1. Translations of German Poetry in American Magazines 1741-1810. By Edward Ziegler Davis, Ph.D. 234 pp. Price ..........

2. The Harmony Society. A Chapter in German American Culture History. By John Archibald Bole, Ph.D. 179 pp. 30 Illustra-

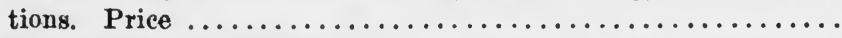

3. Friedrich Schiller in America. A Contribution to the Literature of the Poet's Centenary, 1905. By Ellwood Comly Parry, Ph.D.

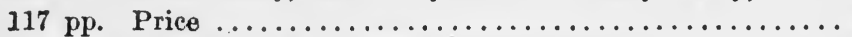

4. The Infuence of Salomon Gessner upon English Literature. By

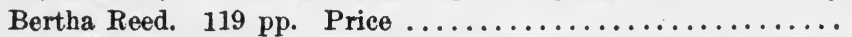

5. The German Settlement Society of Philadelphia and Its Colony, Hermann, Missouri. By William G. Beck. 193 pp. Price ....

6. Philipp Waldeck's Diary of the American Revolution. With Introduction and Photographic Reproductions. By M. D. Learned.

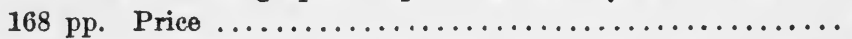

7. Schwenkfelder Hymnnology and the Sources of the First Schwenkfelder Hymn-Book Phinted in America. With Photographic Reproductions. By Allen Anders Seipt, Ph.D. $112 \mathrm{pp.} \mathrm{Price}$

8. The Settlement of the German Coast of Louisiana and the Creoles of German Descent. By J. Hanno Deiler. With Illustrations.

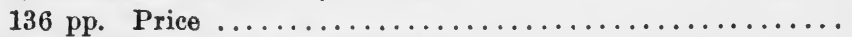

9. Early German Music in Philadelphia. By R. R. Drummond, Ph.D.

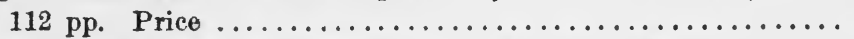

10. "Uncle Tom's Cabin"' in Germany. By Grace Edith MacLean, Ph.D.

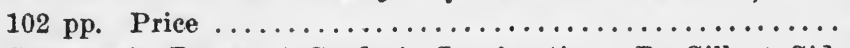

11. The Germans in Texas. A Study in Immigration. By Gilbert Giddings Benjamin, Ph.D. 161 pp. 3 Illustrations. Price .....

12. The American Ethnographical Survey. Conestoga Expedition. M.

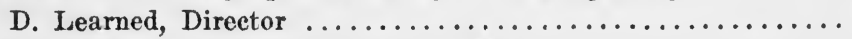

13. Swedish Settlements on the Delaware 1638-1664. With 6 Maps and 150 Illustrations and Photographic Reproductions. By Amandus Johnson, Ph.D. Two Volumes. 908 pp. Price ......... \$10.00

14. National Unity in the German Novel Before 1870. By Roy H. Per-

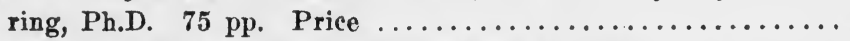

15. Journal of Du Roi the Elder, Lieutenant and Adjutant in the Service of the Duke of Brunswick, 1776-1778. Translated by Charlotte S. J. Epping. 189 pp. Price ....................

16. The Life and Works of Friedrich Armand Strubberg. By Preston

A. Barba, Ph.D. 151 pp. 4 Illustrations. Price ..........

17. Balduin Möllhausen, The German Cooper. By Preston A. Barba,

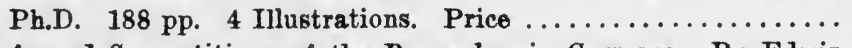

18. Beliefs and Superstitions of the Pennsylvania Germans. By Edwin

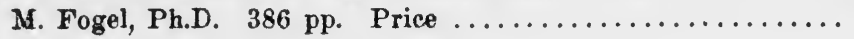




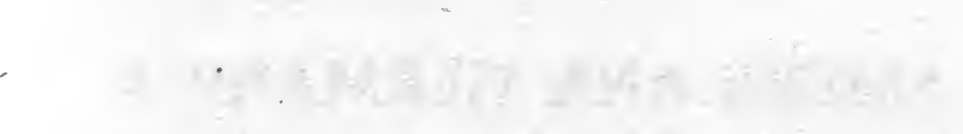






\section{DAY USE}

\section{RETURN TO DESK FROM WHICH BORROWED}

$\mathbf{R E}$

\section{LOAN DFPARTMENT}

This book is due on the last date stamped below, or on the date to which renewed.

Th

Renewed books are subject to immediate recall.

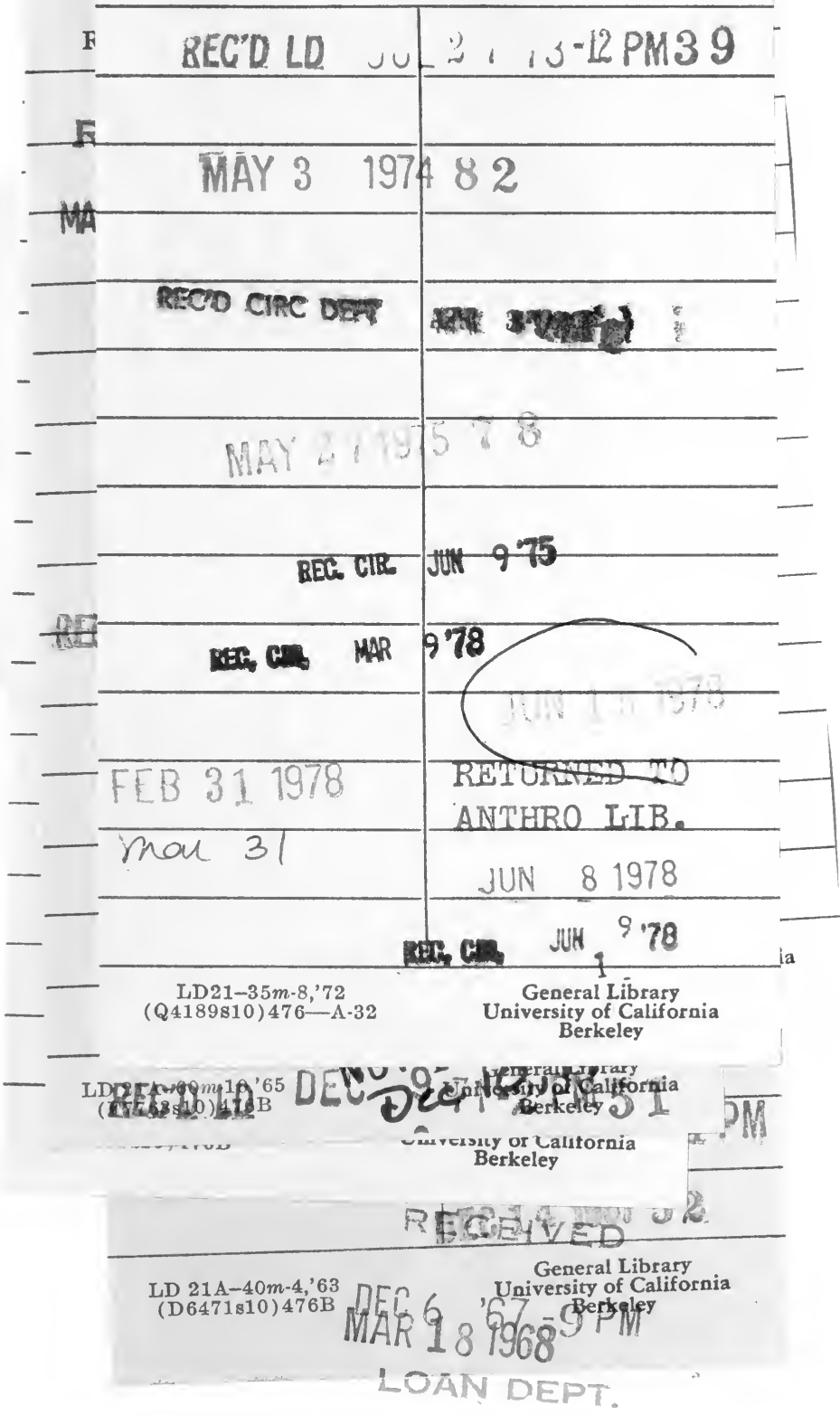




\section{U.C. BERKELEY LIBRARIES | \\ C021068092}
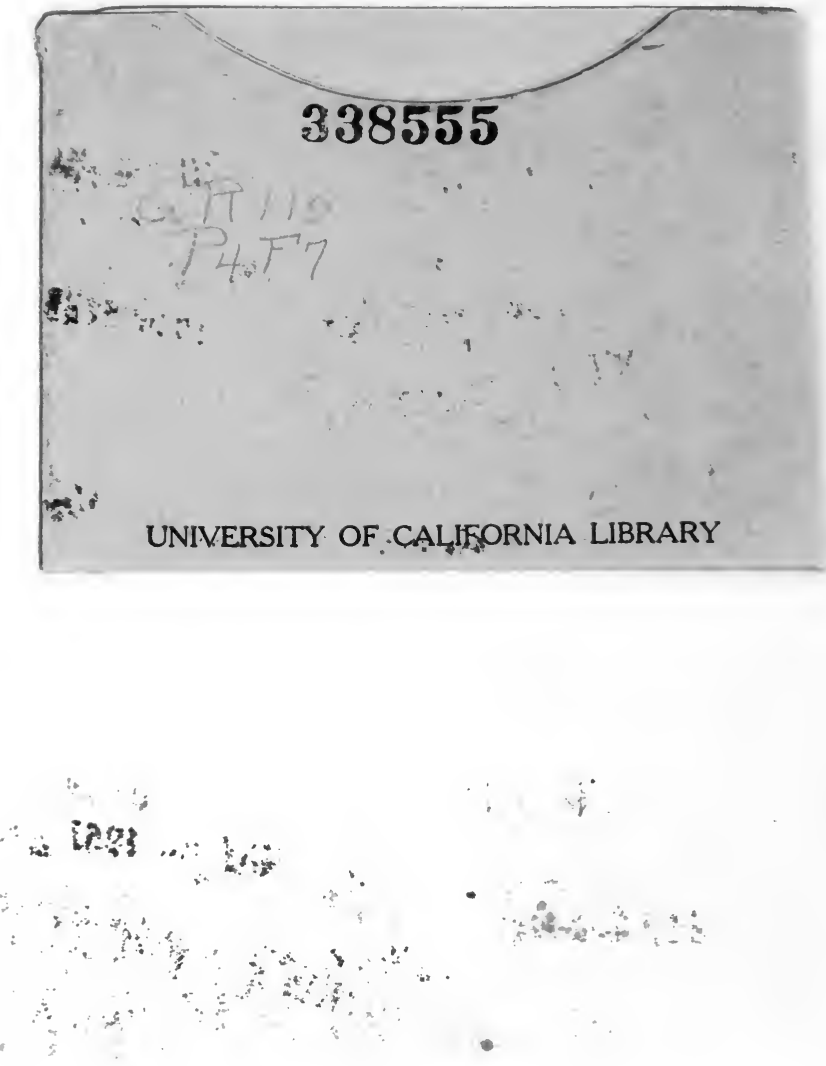
$3 x^{2}$

$15 x^{2}+2=$

1. (5n)

(i)

(5)

(8)

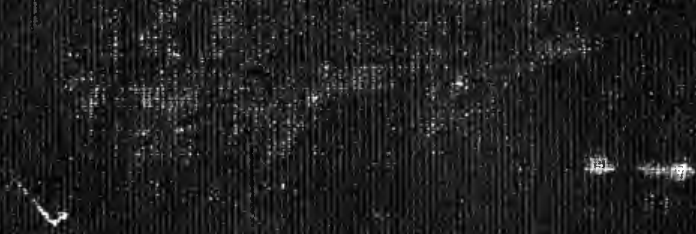

(1)

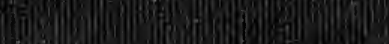

